\title{
Stock Market Manipulation
}

Citation for published version (APA):

Braun, R. (2010). Stock Market Manipulation. [Doctoral Thesis, Maastricht University]. [s.n.]. https://doi.org/10.26481/dis.20101029rb

Document status and date:

Published: 01/01/2010

DOI:

10.26481/dis.20101029rb

Document Version:

Publisher's PDF, also known as Version of record

\section{Please check the document version of this publication:}

- A submitted manuscript is the version of the article upon submission and before peer-review. There can be important differences between the submitted version and the official published version of record.

People interested in the research are advised to contact the author for the final version of the publication, or visit the DOI to the publisher's website.

- The final author version and the galley proof are versions of the publication after peer review.

- The final published version features the final layout of the paper including the volume, issue and page numbers.

Link to publication

\footnotetext{
General rights rights.

- You may freely distribute the URL identifying the publication in the public portal. please follow below link for the End User Agreement:

www.umlib.nl/taverne-license

Take down policy

If you believe that this document breaches copyright please contact us at:

repository@maastrichtuniversity.nl

providing details and we will investigate your claim.
}

Copyright and moral rights for the publications made accessible in the public portal are retained by the authors and/or other copyright owners and it is a condition of accessing publications that users recognise and abide by the legal requirements associated with these

- Users may download and print one copy of any publication from the public portal for the purpose of private study or research.

- You may not further distribute the material or use it for any profit-making activity or commercial gain

If the publication is distributed under the terms of Article $25 \mathrm{fa}$ of the Dutch Copyright Act, indicated by the "Taverne" license above, 
Stock Market Manipulation

Robin Braun 
(C) Robin Braun, 2010

All rights reserved. No part of this dissertation may be reproduced, stored in a retrieval system, or transmitted in any form or by any means, electronic, mechanical, photocopying, recording or otherwise, without the prior permission in writing from the author.

Front cover image: (C) self-designed image with pictures from www.sxc.hu, background is also artwork from Gerhard Richer

Back cover image: (C) Image from www.sxc.hu, artwork by Andreas Gursky and Gerhard Richter.

Accompanying invitations: (C) Artwork by Gerhard Richter

Printed by: Datawyse Maastricht 


\section{Stock Market Manipulation}

\section{PROEFSCHRIFT}

ter verkrijging van de graad van doctor aan de Universiteit Maastricht, op gezag van de Rector Magnificus,

Prof. mr. G. P. M. F. Mols

volgens het besluit van het College van Decanen,

in het openbaar te verdedigen

op vrijdag 29 Oktober 2010 om 10:00 uur

door

Robin Braun 


\section{Promotor}

Prof. dr. R.M.M.J. Bauer

\section{Beoordelingscommissie}

Prof. dr. P.M.A. Eichholtz (voorzitter)

Prof. dr. M. Becht (Université Libre de Bruxelles - ECARES)

Prof. dr. F. Moers

I thank The Maastricht School of Economics of Technology and Organization Research (METEOR), The Foundation for Strategic Environmental Research (MISTRA) and the European Centre for Corporate Engagement (ECCE) for financial support. 


\section{Acknowledgements}

In October 2004 I ran across a charismatic and partly intimidating blockcoordinator of my supposedly last course at Maastricht University (then Universiteit Maastricht). In the blockbook of the course this person dubbed himself "prof. dr. Rob Bauer". His opening words of the first lecture were "my name is Rob Bauer, welcome to 'Institutional Investors', in case you are following three courses at the moment, you are almost certain to fail one of them!”. Personally, I only followed one course so I was supposedly safe from encountering Professor Bauer again in a re-take of the course. But this professor turned out to escort me for a longer time than I had originally anticipated. After "Professor Bauer" has turned into "Rob" and after an enjoyable research for my final thesis, he talked me into a Ph.D. I was supposed to become the first Ph.D. student funded by MISTRA since the inception of The European Centre for Corporate Engagement - ECCE. I felt flattered but was facing a decision between an immediate professional career marked with uncertainty or investing and spending four additional years at university to pursue longer-term goals. Luckily, those four years would pay a salary. I thank Rob for enabling me to pursue the latter path and for giving me the opportunity to develop myself further into an independent researcher. Looking back, I have learned a lot during my doctoral studies. Besides, I experienced an extremely smooth supervision process, which could not have taken place without the help of many others. I have very much enjoyed my time at the department; to do research and to teach over the past four years. Although ex post there has never been any real doubt about the viability of my decision and the outcome, I nevertheless take the opportunity to thank a couple of people, who have accompanied me over the years and who continuously supported me.

First and foremost, I express my gratitude towards Rob Bauer. Rob, I have learned a lot from you and conversations with you always stimulated critical reflection, an aim for continuous improvement, creativity and ingenuity. I have tremendously benefited from your academic and professional experience and hope to develop these skills further in the future. I address an equal degree of gratitude to a source of inspiration, a mastermind in finance, a welcome conversational partner in the area of soccer and simply a nice guy to have around you: Andriy Bodnaruk. Your rich knowledge and comprehensive academic experience, which you always administered in a very humble way, have benefited my doctoral studies to a large 
extent. This has sustainably shaped the way I conduct research. Thank you for your continuous support and your help - even after your departure from Maastricht. I hope and expect that your academic career will flourish further and I wish you all the best and success for that. Further inspiring people to work with have been Gordon Clark and Frank Moers. From you I learned an eye for the "big picture", analytical and theoretical discussions, and selling and marketing strategies of academic research papers. I necessarily also have to thank MISTRA and the ECCE members for financial support, which have enabled this dissertation.

I was in the comfortable situation of keeping the same office space for my entire Ph.D. Thank you Piet for sparing me from any moving and hauling activities and for steering the Finance Department to facilitate my all my possibilities. Besides, I could always teach the same two courses, which I truly enjoyed doing. On the teaching front, I thank the coordinators Stefanie, Luc, and Stefan for being pleasant and inspiring colleagues. Christian and Peter deserve gratitude for sharing their senior experience and advice with me, which contributed to my learning experience. Special thanks are necessarily directed to people, which I shared an office with. Roald and Dennis, thank you for being nice and pleasant colleagues and for giving me a comfortable start at the beginning of my career. Jeroen, I thank you for supporting Rob in his decision to hire me but also for the humorous moments that we shared and for your operationally invaluable advice and hands-on experience. Similar words of appreciation belong to Thorsten, who has been a very enjoyable colleague to work with, who has always been accessible for questions and who shared his experience with me. I wish you and your family all the best in Luxembourg. To Michael of course, I direct best wishes and success for completing his dissertation successfully. Carina, Cécile, Els and Francien deserve gratitude for excellent assistance in all matters, especially towards the final stages of my dissertation.

Colleagues, who have not shared my office but nevertheless have been a major help in the last four years, are certainly Mathijs, Rik, Roy, Ron and Nils. Mathijs and Rik deserve thank-you's, for sharing their rich quantitative knowledge and expertise with me and for giving invaluable advice especially at the beginning of my doctoral studies. Nils, thank you for research-related discussions, endless sports sessions, your continuous effort to integrate new department members. Similar words of gratitude also belong to Ron. Roy, many thanks for drinks and memorable nights in New York City and for your help in steering my career decision. Colleagues from outside the department, who have become friends, are certainly Clemens, Felix, and Julius. Spending and sharing time not only during coffee breaks with you has been a very welcome distraction from my everyday work. My paranimph and long-standing roommate Chris has to be thanked for because of his humor, his friendship, his legendary generosity and his renowned cooking skills. It 
was an enjoyable stay at our nice apartment and I hope we stay in touch in the future.

Lastly, all of my former undergraduate study colleagues and students, which over the years have become friends and who have accompanied my way and, who - hopefully - will continue to do so. My former colleagues at NYU and my friends from New York have enabled me a memorable time and invaluable experiences: a special thanks to you for accompanying me in "the city that never sleeps".

Der letzte und größte Dank gilt natürlich noch meiner Familie, die mich in meiner Entscheidung immer unterstützt hat. Ich hoffe, während der letzten vier Jahre ein pflegeleichterer Sohn gewesen zu sein, der Euch (nicht nur wegen des akademischen Grades) ein wenig mit Stolz erfüllen kann. Vielen Dank für Eure Hilfe und Eure Hinweise. Gleiches gilt ebenso für meinen Bruder und Paranimph Ronald. Auch wenn ich mir relativ sicher bin, dass der Großteil meines Freundeskreises aus Leverkusen über die Jahre wirklich keinen blassen Schimmer von dem hatte, was ich die letzten vier Jahre in Maastricht getrieben habe, trotzdem ein Dank an Euch. Alwin, Andi, David, Przemyslaw, René, und Thomas: das Ergebnis und die Antwort zu Eurer Frage liegt in Euren Händen und ich wünsche gute Unterhaltung. Am Ende der Arbeit findet sich auch eine deutsche Zusammenfassung. Vielen Dank Euch allen und ich hoffe auf eine weitere gemeinsame und langwährende Freundschaft.

Leverkusen, 31 May 2010.

Robin Braun 



\section{CONTENTS}

$\begin{array}{ll}\text { INTRODUCTION } & 1\end{array}$

1.1 Long Term Performance of Shareholder Litigation 4

1.2 Shareholder Litigation and Executive Compensation 5

1.3 Underwriter Manipulation of Initial Public Offerings 6

$\begin{array}{lll}\text { 1.5 Shareholder Activism and Ownership Structure } & 7\end{array}$

1.6 European Corporate Governance and Shareholder Value 8

LONG-TERM PERFORMANCE OF DISTRESSED FIRMS: THE ROLE OF CLASS-ACTION LAWSUITS AND EXPECTED DEFAULT RISK

$\begin{array}{lll}2.1 & \text { Introduction } & 11\end{array}$

2.2 Data and Methodology $\quad 14$

$\begin{array}{ll}\text { 2.2.1 Testable Hypotheses } & 18\end{array}$

2.3 Long-Term Wealth Effects in Class-Action Lawsuits 19

2.3.1 Short-Term Announcement Effect 19

2.3.2 Long Horizon Results 27

2.3.3 Abnormal Returns in Calendar Time 28

2.3.4 The Role of Triggering Events before the Filing Date 33

2.3.5 The Role of Other Stakeholder Groups as External Financiers 35

2.4 Possible Explanations and Practical Implications $\quad 40$

$\begin{array}{lll}2.5 & \text { Conclusion } & 44\end{array}$

Appendix: Sample of Original Allegation Types 46 
$\begin{array}{lll}3.1 & \text { Introduction } & 47\end{array}$

3.2 Data and Empirical Approach 53

3.2.1 Class-action lawsuit data 53

3.2.2 Governance data, financial control variables and equity incentives $\quad 57$

3.2.3 Estimation Method 58

3.3 Empirical Analysis $\quad 59$

3.3.1 Descriptive statistics $\quad 59$

3.3.2 Announcement returns of class-action lawsuit filings 62

3.3.3 Quarterly Performance Volatility Between Groups 64

3.3.4 Who and What Determines Equity Incentives? 66

3.3.5 The Consequences of Insider Determined Equity Incentives $\quad 70$

3.4 Are Lawsuits a Disciplining Device for "Excessive" Risk?

$\begin{array}{lll}3.5 & \text { Conclusion } & 77\end{array}$

LADDERED IPOS: A CASE OF INEFFECTIVE REGULATION? 81

$\begin{array}{lll}4.1 & \text { Introduction } & 82\end{array}$

$\begin{array}{lll}4.2 & \text { Data } & 86\end{array}$

4.2.1 Data Sources 86

4.2.2 Descriptive Statistics of Laddered IPOs 88

4.3 Laddering and Underpricing $\quad 89$

4.3.1 Methodology $\quad 89$

4.3.2 Results without controlling for endogeneity 95

4.3.3 Results after controlling for endogeneity 100

4.4 Laddering and Investment Bank Behavior 100

4.4.1 Laddering and Stock Performance 101

4.4.2 Laddering and Investment Bank Ownership 108

4.5 Laddering and Insider Behavior $\quad 114$

4.5.1 Laddering and Insider Trading 114

4.5.2 Laddering and the Market Impact of Insider Trading 118

$\begin{array}{ll}\text { 4.6 Laddering again? } & 122\end{array}$ 


\section{INDUSTRY COMPETITION, OWNERSHIP STRUCTURE AND SHAREHOLDER ACTIVISM}

5.1 Introduction

5.2 Economic Framework and Testable Hypotheses

5.3.1 Shareholder Proposals and Annual Meeting Information

5.3.2 Insider Ownership Data

5.3.2 Shareholder Base Data

5.3.3 Firm, Industry and Governance Characteristics

5.4 Descriptive Statistics

5.4.1 Shareholder Proposals over Time

5.4.2 Governance and Industry Competition

5.4.3 The Heterogeneity of the Institutional Investor Base 
THE EMERGING MARKET FOR EUROPEAN CORPORATE GOVERNANCE: THE RELATIONSHIP BETWEEN GOVERNANCE AND CAPITAL EXPENDITURES, 1997-2005

6.1 Introduction

6.2 Theory of European Corporate Governance

6.3 Study Data and Methodology

185

6.3.1 Data

185

6.3.2 Methodology

$\begin{array}{lll}\text { 6.4 Results of Empirical Estimations } & 193\end{array}$

$\begin{array}{lll}\text { 6.4.1 Findings for Region One } & 194\end{array}$

$\begin{array}{lll}\text { 6.4.2 Findings for Region Two } & 195\end{array}$

6.4.3 Findings for the United Kingdom and Ireland 195

$\begin{array}{lll}\text { 6.4.4. Robustness Checks } & 199\end{array}$

6.4.5 Generalized Methods of Moments 202

6.5 Practice of European Corporate Governance 203

$\begin{array}{lll}\text { 6.6 Conclusions } & 205\end{array}$

Appendix A - Description of Deminor's rating algorithm 208

$\begin{array}{ll}\text { CONCLUSION } & 211\end{array}$

$\begin{array}{lll}7.1 & \text { Summary of Main Findings }\end{array}$

$\begin{array}{lll}7.2 & \text { Implications of Empirical Results } & 214\end{array}$

7.3 Suggestions for Further Research 216

$\begin{array}{ll}\text { BIBLIOGRAPHY } & 219\end{array}$

$\begin{array}{ll}\text { DEUTSCHE ZUSAMMENFASSUNG } & 241\end{array}$

$\begin{array}{ll}\text { CURRICULUM VITAE } & 247\end{array}$ 


\section{Chapter 1}

"It's not a question of 'enough', pal. It's a zero-sum game. Somebody wins, somebody loses. Money itself isn't lost or made, it's simply transferred... from one perception to another, like magic."

Gordon Gekko, from “Wall Street” (by Oliver Stone)

\section{Introduction}

Public securities markets are among the most important source of external financing for companies and entrepreneurs. In the last three years a total of over 2.4 trillion U.S. Dollars in over 9,900 issues have been raised globally in equity and equity related transactions, of which 520 billion has been from initial public offerings of common stock. Still, this constitutes only around $10 \%$ of external plain vanilla sources of capital ${ }^{1}$. The evolution from a start-up firm to a large company requires expansion and ongoing refinancing of operations by the generation of capital - either from internal or external sources. Raising capital from equity markets is by no means an imperative step in a company's development as examples of long-standing private multinationals such as Fidelity Investments and Cargill clearly demonstrate. The recent wave of firms "going dark" shows that public equity markets also bring along a cost: namely the loss of managerial autonomy and market pressures (Boot, Gopalan, and Thakor, 2008).

Any outside financing decision with equity generates a separation of ownership and control, which gives rise to a principal-agent conflict (Jensen and Meckling, 1976). A financing mix of debt and equity creates a further conflict between shareholders and bondholders. When managers or corporate insiders require outside financing, they turn to capital markets. The issuance and distribution of securities is usually commissioned to financial intermediaries - so-called investment banks, which produce information to assure valuation, to assess and

\footnotetext{
${ }^{1}$ Source: Thomson Reuters volume trends last three years-to-date (8 April 2010)
} 
solicit demand, and the allocation of securities to potential investors. In order to succeed in raising capital of any kind to begin with, the manager has to make corporate decisions in order to signal a healthy firm condition to the market, steady cash flows and prosperous growth opportunities. This is a necessary condition in order to stimulate demand for the firm's securities in the first place. Capital markets are constituted by subjects, who trade assets either on regulated exchanges or overthe-counter, where a market price is assigned to the traded good, based on the available information set and expectations. In turn, these expectations of public capital markets and their constituents affect the ways, in which managers steer corporations. These expectations are not homogeneous across investor types because shareholders prefer risk, whereas bondholders prefer a low probability of default. Research suggests that there are also clienteles within these two groups (Miller, 1977). After raising external capital from equity markets, managers do not act as sole proprietors anymore, which causes their interests to potentially diverge from new owners of the firm: the shareholders. Not only has the recent and ongoing global financial crisis underscored the importance of transparency, managerial accountability and the degree to which investors are able to exert control - it has also shown limits to the regulatory framework.

The early finance literature advocates frictionless capital markets, which among other elements - assumes that every market participant has the same access to information (Miller and Modigliani, 1958). A later strand of research has challenged this view, which has led to the emergence of early signaling models (Akerlof, 1970, Spence, 1973). These have been further developed in all kinds of theoretical settings. In reality though, any securities market bears frictions because information availability is not universally equal. The phenomenon that insiders know more about the financial condition and the growth prospects of a company than prospective investors do is commonly known as asymmetric information (Myers and Majluf, 1984; Miller and Rock, 1985).

This does not necessarily undermine or prevent the optimal operation of securities markets: participants merely respond differently, which alters the rules of the game and enables the emergence of alternative market mechanisms - partially because of regulatory intervention. Probably the most prominent market mechanism, which assures the functioning of capital markets and the return that investors get, is known as corporate governance (Shleifer and Vishny, 1997). The interpretation of this mechanism differs globally and both regulatory amendments advances have been made in each country - most prominently with the passage of the SarbanesOxley Act in the United States in 2002. This was enacted in response to managerial misconduct and highly politicized governance scandals. 
The title "Stock Market Manipulation" of this dissertation by no means is supposed to connote forensic or criminal backgrounds. I strongly acknowledge that managers signal their proprietary information to capital markets in order to augment informational efficiency, to become more transparent and for investor relations purposes to stimulate demand for corporate securities. However, the presence of asymmetric information also enables managers to potentially capitalize on their access to inside information and to violate the terms of the contract under which control rights to the company's assets and cash flows have been pledged to the shareholders (Hart, 1995). The questions that I seek to explore in this dissertation are threefold. Firstly, what are potential situations where asymmetric information has been exploited, where subjects have acted in self-interest and what has caused this behavior? Secondly, what are the consequences of these situations? Lastly, can market participants, the social planner, or the regulator prevent these situations from happening? And if so, how should preventive and corrective action look like?

In this dissertation, I will give answers to each of the questions with empirical analyses of both American and European stock market and company data. Chapters 2 and 3 will argue for shareholder litigation to be one credible corporate control device, which shareholders can resort to, once insiders have allegedly violated managerial duties. I measure shareholder litigation through the filing of class-action lawsuits and investigate their causes and consequences. According to my results, causes are an "excessive" managerial compensation with stock option combined with managerial discretion. Consequences are underperformance or reversals of stock price performance conditional on the allegations affecting individual directors only rather than the corporate entity. I conclude a disciplining effect from the threat of shareholder litigation due to adverse stock price effects for the equity-aligned manager.

Whereas Sarbanes-Oxley seems to constitute an effective regulatory intervention, which substitutes costly litigation, Chapter 4 points out a part of regulation, which is less likely to be successful. I observe situations of stock market manipulation in the process of initial public offerings during the hot issue period between 1998 and 2000 in the United States. The practice of soliciting demand for shares and eventually allocating shares in public equity markets is delegated from the issuer to the underwriting investment bank. This creates an agency problem because the financial intermediary holds superior information. There is a mechanism, which the underwriter can exploit this to manipulate demand, allocation, and the aftermarket pricing of shares in order to please the issuer. This by itself is not unlawful. The investment bank does so however, at the expense of uninformed minority investors, which are not in the eligible circle of the investment bank's client base. The practice does not assume implicit collusion between the underwriter and corporate insiders. I provide indicative evidence of underwriter 
involvement, price stabilization, and stronger insider selling activity - even aside of regulatory notice. Besides finding support of "captive regulation", I also contribute to the emerging and politicized literature on coordinated behavior of financial conglomerates.

Chapter 5 shows how shareholders can enforce corporate control in the form of either selling the shares (following the "Wall Street Rule" or "voting with their feet") or to file proposals (to use "voice") affecting the corporate strategy at shareholder meetings. In the absence of industry competition or an active market for corporate control, shareholders will resort to filing proposals and to undermine a managerial "quiet life". I show that the probability and the extent of the enforcement of governance via "voice" is also a function of ownership structure. Because managers in these types of firms are predominantly equity-aligned, they will find it optimal to actively use their voting rights in order to block shareholder proposals.

In my last chapter, I provide international evidence of how corporations respond to an increasingly changing landscape of corporate governance and institutional shareholder expectations. Using European data and distinguishing three corporate governance regimes by legal heritage and shareholder value approaches, I show that Continental European firms - from a long-term large investor system -are increasingly sensitive to complying with Anglo-Saxon principles - a market-based system. These comprise a dominant focus on short-term shareholder value creation at the expense of long-term capital expenditures. Using investor-sensitive corporate governance ratings between 1997 and 2005, I find that (also because of regulatory intervention) Continental European firms increasingly converge to their peers in the United Kingdom in terms of corporate governance. The extent to which corporations can manage to please developments in their shareholder base therefore constitutes a form of stock market manipulation as well.

In the next sections, I will outline each chapter shortly by mentioning major building blocks from the theoretical and empirical literature. This introduces the main problem statements and research questions, which precede the actual findings of each chapter.

\subsection{Long Term Performance of Shareholder Litigation}

What happens to firms that get sued by their shareholders and does litigation have any merits beyond settlement amounts? In this chapter I argue that shareholders can effectively use shareholder litigation to discipline managers. I measure litigation activity with the filing of class-action lawsuits. In 1995, the U.S. Congress enacted the Private Securities Litigation Reform Act (PSLRA) that enables (private) shareholders to allege any violation of 10(b)-5 of the 1934 Securities 
Exchange Act. This rule prohibits among other things any manipulative and deceptive practices by managers and corporations and it prescribes managerial duties. Essential to my analysis is the distinction between allegations of violations of duty of care versus violations of duty of loyalty. I posit that only for lawsuits, which affect individual directors, there is potential for a disciplining effect, which translates into long-term reversal of performance. By contrast, lawsuits affecting the corporate entity will be disruptive and will result in long-term underperformance due to loss in investor confidence. Before litigation, sued companies behave like large growth stocks, which transform into small value firms post litigation. This finding is consistent with the theoretical model by Kedia and Philippon (2009). I find that if violations of duty of loyalty are alleged - exemplified by insider trading or related party transactions - negative stock price performance reverses over medium- to long-term horizons and generates significantly positive alpha. This finding is not present for allegations of violations of duty of care. This resembles indicative evidence that individuals can be disciplined - corporations cannot.

However, shareholder litigation cannot be an effective governance mechanism if it erodes the corporation's financial health and puts it nearer to financial distress. If it will, then this outcome is merely a wealth transfer from bondholders to shareholders. I measure the possible occurrence of financial distress with an approximation of Merton's distance-to-default (1974) model following Bharath and Shumway (2008). Even though default probabilities of $12.08 \%$ in sued firms range higher than the unconditional average of $8.07 \%$, they do not increase after the filing of a lawsuit. My results aid and steer institutional investors' decision making of whether to use shareholder litigation and to join class-action lawsuits. A dual holding of bonds and equity in the firm should not affect this decision.

\subsection{Shareholder Litigation and Executive Compensation}

Turning to the antecedents of shareholder litigation, I focus on CEO compensation and (dysfunctional) corporate governance mechanisms. Departing from established models of executive compensation I offer an alternative interpretation of the occurrence of class-action lawsuits: the emergence of a governance mechanism if other mechanisms are unavailable or have failed. It is widely understood that the market for corporate control as a disciplining device can be undermined with the use of takeover defenses (Comment and Schwert, 1995). Further, in a system of dispersed ownership, changes in corporate governance are often difficult to attain - even for blockholders. Lastly, selling the stock and thereby depressing the stock price is often not an option for large shareholders with indexed portfolios. These shortcomings might suggest that CEOs have a blank check for 
selfish behavior and increasing firm risk. So which option of corporate control can minority shareholders resort to? And who should set executive compensation in a system of dispersed ownership where blockholders can pursue different objectives and $\mathrm{CEO}$ behavior with discretion can be problematic?

I argue that shareholder litigation is an available ex ante threat and ex post disciplining device in response to excessive managerial risk taking. Due to asymmetric information and the presence of discretion, a CEO will negotiate for option compensation. I measure "excessive" as the component of CEO compensation, which is determined by managerial discretion rather than economicand firm variables. I find out that consequences of "excessive" option compensation are an increase in firm risk, which increases the likelihood of shareholders resorting to class-action lawsuits as a control mechanism. This is because options have a nonlinear payoff function, whose value also increases with the volatility of the stock. Not only does it increase the likelihood, it also increases the potential severity and the accompanying stock price impact. Because the filing of lawsuits can be a costly endeavor not only for a dispersed shareholder, it is intriguing to seek for a more cost-efficient alternative ex ante control mechanism. I find this in the passage of Sarbanes-Oxley (SOX) personal liability section, which resembles an exogenous shock to the U.S. corporate governance landscape. CEOs could already be sued personally before SOX but can now be held personally liable to a higher extent. Hence, I offer an alternative interpretation to the occurrence of class-action lawsuits: not merely as a consequence of negative performance but as a response from shareholders to excessive compensation.

\subsection{Underwriter Manipulation of Initial Public Offerings}

Which role does regulatory intervention into financial markets play and why do we observe it? Using data of initial public offerings (IPO) between 1995 and 2007 and identifying causes and consequences of shareholder litigation against issuers and underwriting investment banks, I give answers to the paramount degree of underpricing in hot issue markets. I study a notorious investment bank practice on Wall Street known as tie-in agreements ("laddering", henceforth). It is likely that this only works for initial public offerings and not for seasoned offerings because information asymmetry is lower in listed companies. The mechanisms are the following. With book-building the underwriting investment bank has sole discretion upon the allocation of IPO shares as soon as demand exceeds supply (the issue is oversubscribed). The underwriter will then allocate the IPO shares to investors at the offer price conditional on these same investors committing to purchase additional stock in the aftermarket on predetermined dates. This practice is deceitful to those 
investors unaware of this stock price manipulation and undermines the integrity of financial markets. This practice has substantial effects on the first day return of the IPO: the underwriter levers its reputation in the IPO market in order to entice prospective investors to participate in the illegal scheme. More than that, there is also a substantial degree of underwriter post-IPO involvement in the form of ownership through the financial conglomerate's asset management arms. This is further evidence to coordinated behavior of financial conglomerates (Acharya and Johnson, 2007; Bodnaruk, Massa, and Simonov, 2009; Ritter and Zhang, 2007). The consequence of that is a stabilized stock price, which does not statistically underperform a matched non-manipulated sample and outperforms the average IPO firm. Potential beneficiaries (with or without direct awareness of laddering or implicit collusion with the underwriter) are corporate insiders and pre-IPO investors, which can exit more easily and at higher prices. And indeed, I find that insiders of laddered IPOs sell their shares earlier, at higher volumes and to a stronger extent: irrespective of which insider type I consider or whether I put restrictions on minimum trading amounts I find that laddered firm insiders are significant net sellers. This holds over almost all medium term time windows after the IPO that I consider.

Given the lucrative nature of this practice, it appears astonishing why laddering allegedly ceased to occur after 2000. Decreasing stock markets and an increasing awareness of the financial press have caused an exogenous change in the degree of the enforcement of Regulation $M$, which intends to proscribe actions of market manipulation. Using a Probit model of laddering occurrence between 1995 and 2000, I estimate coefficients to calculate the out-of-sample probability of IPOs to be laddered post 2001. Based on these probabilities, I find IPO firms, which share the same characteristics of underpricing, underwriter involvement and insider trading activity like de facto laddered IPO firms. This suggests that in spite of regulatory intervention, a practice similar to laddering still takes place. The fact that regulatory change did not cause different behavior of the regulated subjects is an evidence of "captive regulation". In August 2009, U.S. courts have proposed a global settlement amount of USD 586 million relieving 309 issuers and over 40 involved underwriting investment banks from any further legal liability - without legally admitting wrongdoing.

\subsection{Shareholder Activism and Ownership Structure}

In the broad spectrum of corporate governance and its available mechanisms, "exit" and "voice" constitute two widely used forms, which will become more prominent in the future (Gillan and Starks, 2007). Owing to the increasing fraction of institutional ownership since the mid 1990s, investors become 
more and more influential when it comes to having a say in the corporate strategy. At the same time, this coincides with shifts in the proportions of the institutional shareholder base between "transient" (high turnover, short-horizon), "dedicated" (concentrated long-term holdings), and "quasi-index" (low turnover, high diversification) investors.

Shareholder proposals can take a variety of facets on terms of proposal content and motivation. I find that both content and sponsor identity strongly affect the outcome and success of shareholder proposals. In this chapter, I argue that (institutional) investors will - in the absence of the "exit" option - file shareholder proposals to those firms, which are insulated from the market for corporate control and where industry competition is absent. Managers in these firms lack punishing devices ("sticks") and downside risk in case of below-average performance, which is why they need to be incentivized with equity participation ("carrots") to exert optimal effort. Controlling for the endogeneity of the shareholder base, I argue that the emergence and the magnitude of shareholder proposals are strongly related to both ownership- and governance structure of the firm. However, the outcome and the effectiveness of shareholder proposals are most likely driven by insider holdings. Since managers in firms with weak governance and non-competitive industries are likely to enjoy a "quiet life", I argue that managers in these firms will negatively affect the outcome of proposals to obstruct any outside shareholder intervention into corporate policies. Proposals in this group of firms are therefore less likely to be successful. I explain the lower stock market valuation of these firms with a "lack of control discount" similar to the "dual-class discount" established by among others Gompers, Ishii, and Metrick (2009), Zingales (1995). But there is negative publicity of filed shareholder proposals and significant opportunity costs to deal with them from the managers' side. In spite of discretion, managers in these firms are not able to shirk and exert suboptimal effort; therefore shareholder activism is effective.

\subsection{European Corporate Governance and Shareholder Value}

The question of corporate governance and control mechanisms available for shareholders cannot be unambiguously answered without expanding the American perspective to European stock markets. Corporate governance regimes and legal heritage can be classified into market-based and a long-term large investor-based system and common law and civil law, respectively (Becht, Bolton, and Röell, 2003). The Anglo-Saxon system of corporate governance defines a corporation's goal as the creation of value for shareholders - the ultimate owners of the firm. The continental European (German-Japanese) system however sees a corporation's duties in the creation of value for all stakeholders, which ultimately affects a 
company's approach to shareholder value and investment horizons (Tirole, 2001). The motivation for this study stems from findings of Gompers, Ishii, and Metrick (2003), who find a tendency of poorly governed firms to overinvest. This however holds for the U.S. market - a uniform region of corporate governance and regulations. Internationally, anecdotal evidence from the Dutch retailer Royal Ahold and German automotive multinational Daimler Chrysler (after divestment of Chrysler in 2007 named "Daimler AG") exemplified how shareholder pressures can manipulate corporate investment strategy.

Because institutional investors show an increasing aptitude and penchant for the Anglo-Saxon system of corporate governance, I argue that continental European firms will increasingly converge towards the Anglo-Saxon model of corporate governance. In order to empirically test my argument, I use a unique dataset of investor-sensitive corporate governance quality of Europe's 300 largest (FTSE EuroTop) corporations between 1997 and 2005. The European market proves to be an ideal experimental setting due to heterogeneous governance structures and regulations. I regress the investment activity of company $i$ in region $j$ in year $t$ on a number of control variables and the corporate governance quality and find similar effects. This result holds in spite of differences in legal heritage and ownership and is robust to serial correlation. The finding is strongest for that element of corporate governance, which is the least regulated on a European level: the range of takeover defenses. Because continental European managers have to adhere to expectations of an international institutional shareholder base, which abides to Anglo-Saxon governance standards, they steer corporations more towards delivery of short-term value. Managers respond to this by cutting on capital expenditures and manage for retained earnings.

The following chapters of this dissertation will more fully address each of aforementioned topics in greater detail. Both databases and the empirical testing methods will be thoroughly explained together with findings and discussion of implications of each chapter. Chapter 7 concludes this dissertation with inference from my research and avenues for future research. 



\section{Chapter 2}

\section{Long-Term Performance of Distressed Firms: the Role of Class-Action Lawsuits and Expected Default Risk ${ }^{1}$}

Does shareholder litigation pay off for investors over long horizons and how much does the type of allegation matter? We study whether a disciplining effect occurs for distressed firms and their managers and examine two different groups of allegations. Allegations of violations of duty of loyalty effect individuals only, but duty of care pertains to the corporate entity. After litigation we observe a general transformation in firm characteristics and risk exposures, which is consistent with theory. Although generally negative, short- and long-term performance effects differ substantially between types of allegations. We observe performance reversals only in firms with individual directors accused of insider trading. Effects are similar for firms with triggering events that precede the initiation of a lawsuit. At the same time we fail to observe a simultaneous decrease in financial health in the form of their expected default frequency. Our results have important implications for regulator and institutional investor decision-making and monitoring strategies: whether to use litigation to exert control on managers, even in the presence of dual holdings of debt and equity.

\subsection{Introduction}

Corporations can obtain external financing via a contract between the firm as a legal entity and its prospective financiers. In the process of raising external capital the firm pledges its assets vis-à-vis control rights for the investors (Hart, 1995). If a firm violates the terms of the agreement in any form, then the claimholders can legally enforce their rights in court. Shareholders in the United States - as one major group of external financiers - have the right to resort to class-

\footnotetext{
${ }^{1}$ This chapter is based on Bauer and Braun (2010), which is forthcoming at the Financial Analyst Journal under the title "Misdeeds Matter: Long-Term Stock Price Performance of Firms after the Filing of ClassAction Lawsuits"
} 
action lawsuits when they believe that their agents have violated the duty of loyalty or the duty of care (Shleifer and Vishny, 1997). Typically, regulators in the U.S. are fairly strict in the interpretation of managers' duty of loyalty. The question that we ask in this paper is what happens to financial claimholders if these duties are allegedly violated.

Recent developments in financial markets have accelerated the rate of class-action lawsuits. Stock market valuations, significantly above fundamental levels between 1998 and 2001, have resulted in the burst of the internet bubble and consequently a large number of dissident shareholders. Allegations during this time period focused on inflated stock prices, shareholder wealth-destroying mergers and acquisitions, false IPO prospectuses, and managerial insider trading. After 2001, the cases of Enron, Tyco, WorldCom, Global Crossing, and Adelphia resulted in a large number of governance-related lawsuits. In 2005, two of Adelphia's family members were sentenced to prison and a settlement fund of $\$ 2.5$ billion was established to benefit the plaintiff class. More recent observations include the option-backdating scandals and excessive risk-taking in the subprime crisis. According to The Economist (19 December 2007), shareholders filed class-action lawsuits on an "annual pace of around 270 between August and October 2007." In 1995, the U.S. Congress enacted the Private Securities Litigation Reform Act (PSLRA) that enables (private) shareholders to allege any violation of 10(b)-5 of the 1934 Securities Exchange Act. This rule prohibits among other things any manipulative and deceptive practices by managers and corporations and prescribes managerial duties. According to Romano (1991), these can be subdivided into duty of care and duty of loyalty. The latter term describes fiduciaries' conflicts of interest and requires them to put the corporation's interest ahead of their own. Typically, this includes selfdealing and related party transactions. The focus of this paper is the alleged violation of the duty of care, which requires the execution of "reasonable skills, diligence and especially taking care in board actions." The allegation of self-interested managerial misconduct and the post-evaluation of poor business decisions both fall under the violation of duty of care (Loss and Seligman, 2004).

Becht, Bolton, and Röell (2003) classify the threat of shareholder litigation as a governance mechanism. If this is true, shareholders are able to exert control with the initiation of lawsuits. An unresolved issue so far is the actual credibility of the threat and its reputational and financial costs for managers. Given that equitylinked incentives constitute a major part of American directors' and officers' total compensation (Hall and Liebman, 1998), shareholder litigation also materially affects their overall pay package. According to Fich and Shivdasani (2007), there is also a significant amount of reputational risk at stake for managers of sued corporations. Can managers actually fear shareholder litigation due to materially longer term adverse stock price reactions? 
In this paper, we analyze various types of allegations brought forward in a class-action lawsuit and their short- and long-term effects on shareholder value. In particular, this paper addresses the following questions. When are class-action lawsuit filings likely to occur and what are the immediate stock price reactions to them? Can we discriminate between different types of allegations and do they differ in returns across event windows? How do sued firms perform over a longer term and what is the role of a triggering event before the filing of a lawsuit? Can shareholder litigation discipline managers ex post and should they fear the ex ante threat? We adopt the perspective of an investor in a firm, who has become disgruntled with the firm's stock price performance and/or who suspects illegal actions and faces the question of alleging violations of Rule10(b)-5 to file a lawsuit. Under what circumstances does it pay off for the investor and how much time has to elapse until performance reverses and the investor profits in the long term? Does any long term recovery occur at the expense of the firm's creditors or is litigation a pure disciplining device?

We document several results. Shareholder litigation occurs frequently in the United States. In many cases poor stock performance triggers litigation, which is why shareholders actively monitor managers and seek to claim damages. Shareholders sue corporations for a variety of reasons, which all differ in terms of short- and long-term shareholder wealth effects. This result is robust to alternative specifications and holds for a variety of event windows. Using a feasible investment strategy of calendar-time abnormal returns we show that a portfolio of all sued companies underperforms over long horizons of up to 48 months after litigation, after correcting for conventional risk factors. However, if shareholders sue only selected directors rather than the entire corporate entity, then we do not observe this underperformance. We explain this result as direct evidence of a disciplining effect on individual corporate decision-makers. Our result does not come at the expense of creditors in the form of a higher probability of default. The financial literature frequently advocates our method to produce unbiased long-term performance results subsequent to any form of corporate events. To the best of our knowledge, we are the first ones to empirically establish credible long-horizon performance of distressed firms facing litigation using a feasible investment strategy, which closely resembles shareholders' short- and long-term horizons.

We contribute to the literature of corporate governance, shareholder litigation, and long-term performance in various ways. The fact that lawsuits occur in response to bad stock price performance supports the empirical predictions of Povel, Winton, and Singh (2007). Incentives for directors to manipulate and to defraud are highest in boom times because shareholders' degree of monitoring and vigilance is lowest. Our analysis shows that a class-action lawsuit filing against firms is a materially adverse event in the sense of short- and long-term performance 
effects. Unlike Karpoff, Lee, and Martin (2008a\&b) and Fich and Shivdasani (2007), we do not only measure losses borne by shareholders of firms being de facto charged with an $S E C$ or $A A E R$ investigation, respectively, but focus on all firms sued by their shareholders. This way we can document a pure filing effect irrespective of the allegations' legitimacy. Moreover, we discriminate between the type of allegation, which the corporation faces, and document significant differences. We propose a method to measure the long-term performance of sued companies and note that results are also highly sensitive to momentum.

Whether and how distressed firms fare over the long term in litigation has important policy implications with respect to the actual costs borne by shareholders in the market. If stock prices do not recover over medium to long horizons this implies that shareholders in the aggregate market lose out and only plaintiffs and lawyers gain. If share prices recover but bankruptcy risk increases, then we conclude that there is a wealth transfer from creditors to shareholders. A major conclusion that emerges from our results is that class-action lawsuits appear to be a powerful tool to discipline managers and it has a reasonable ability to exert influence on distressed firms without any wealth transfer involved. Practical contributions are to help and steer the decision-making process of institutional investors: even the presence of dual positions need not deter them from using litigation as a means of exerting control.

We organize this paper as follows. Section 2 gives an overview of our data sources and outlines our methods, which we explain further in section 3 . In this section we also show our results of various types of long-term performance and a naïve version of the Merton-KMV distance to default measure. Section 4 discusses our findings from a corporate governance perspective and contrasts subsample results. Section 5 is the conclusion.

\subsection{Data and Methodology}

Our primary source of data is the securities class action clearinghouse maintained by Stanford Law School in collaboration with Cornerstone Research. ${ }^{2}$ In existence since 1996, the database includes more than 2800 companies that list either on the NYSE, AMEX, or NASDAQ. The database also includes private and $O T C$-traded companies as well as foreign issuers (who also fall under U.S. securities law regulations). We hand-collect case by case information and identify seven main reasons for shareholders to go to court against the corporation. Table 2.1 lists these reasons below. In the Appendix, we provide a sample of firms in order to clarify our coding and grouping methods. These allegations are not mutually exclusive and can

\footnotetext{
${ }^{2}$ This database is available online via http://securities.stanford.edu
} 
amount to a theoretical maximum of seven allegations at the same time. We deliberately decide to retain cases on insider trading and related party transactions. Allegations of this type fall under the violation of duty of loyalty and are less likely to affect the whole firm. Our source of data for daily and monthly stock returns is CRSP. Market benchmark return and SMB, HML, and Momentum factors are from the website of Kenneth French. For the analysis in Subsection 3.5, we collect accounting data from COMPUSTAT in order to compare pre- and post-litigation firm characteristics; most importantly expected probability of default according to the methods of Bharath and Shumway (2008).

For the purpose of isolating a true "filing effect", we also identify whether any triggering event has preceded the filing of the lawsuit. We classify triggering events as events where a material correction of management's earnings forecasts take place before the filing date of the class-action lawsuit. Alternative triggering events can be the initiation of a $S E C$ investigation, self-disclosure of accounting problems, resignation of key executives, or severe problems in the auditing process. In the final sample of 650 companies during the period of 1996 to 2007, a triggering event preceded the filing in over $55 \%$ of the cases. In Subsection 3.4 we discriminate between firms with and those without triggering events.

As can be seen in the table the annual number of class-action lawsuits peaks in 2002 after the bubble burst. This gives a first indication that class-action lawsuits are a response to decreasing stock markets. This is also in line with Povel, Singh, and Winton (2007) who state that managers' incentives to manipulate are largest in boom times because shareholders are less vigilant. Following 2002 and the enforcement of Sarbanes-Oxley, we also observe a sharp increase in lawsuits related to corporate governance. False and misleading statements, often coinciding with stock price manipulation are the prime allegations brought forward by shareholders.

Panel B shows in which industries class-action lawsuits are most prevalent. The four most litigation-vulnerable sectors are retail (FF9), manufacturing (FF3), consumer durables (FF2), and energy (FF4). Since the business equipment (hightech firms, etc.) sector is usually highly dependent on growth opportunities it surprisingly does not show up as an exposed sector in terms of litigation risk. A possible explanation is that high growth typically does not coincide with firms being large in terms of assets. Typically, large firms are sued for their deep pockets (DuCharme, Malatesta, and Sefcik, 2004). We stress that our sample does not discriminate between ex post meritorious or frivolous lawsuits, which tend to be lawyer-driven. Our objective is to find a pure filing effect of a lawsuit against companies and to find out if the filing has merits beyond the aimed settlement amount. Therefore an analysis of ex post successful lawsuits only, as in Fich and Shivdasani (2007), can bias our results downwards. 


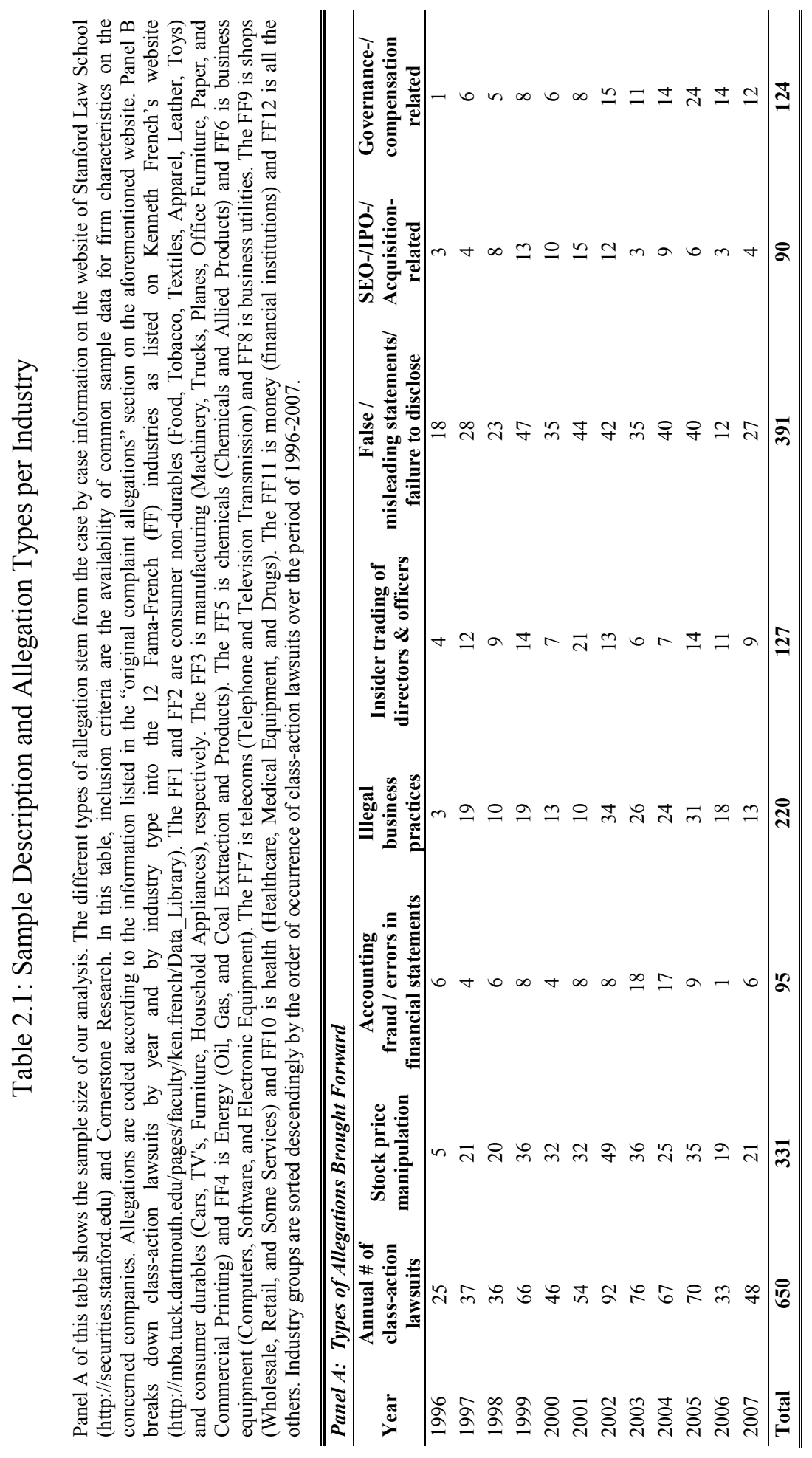




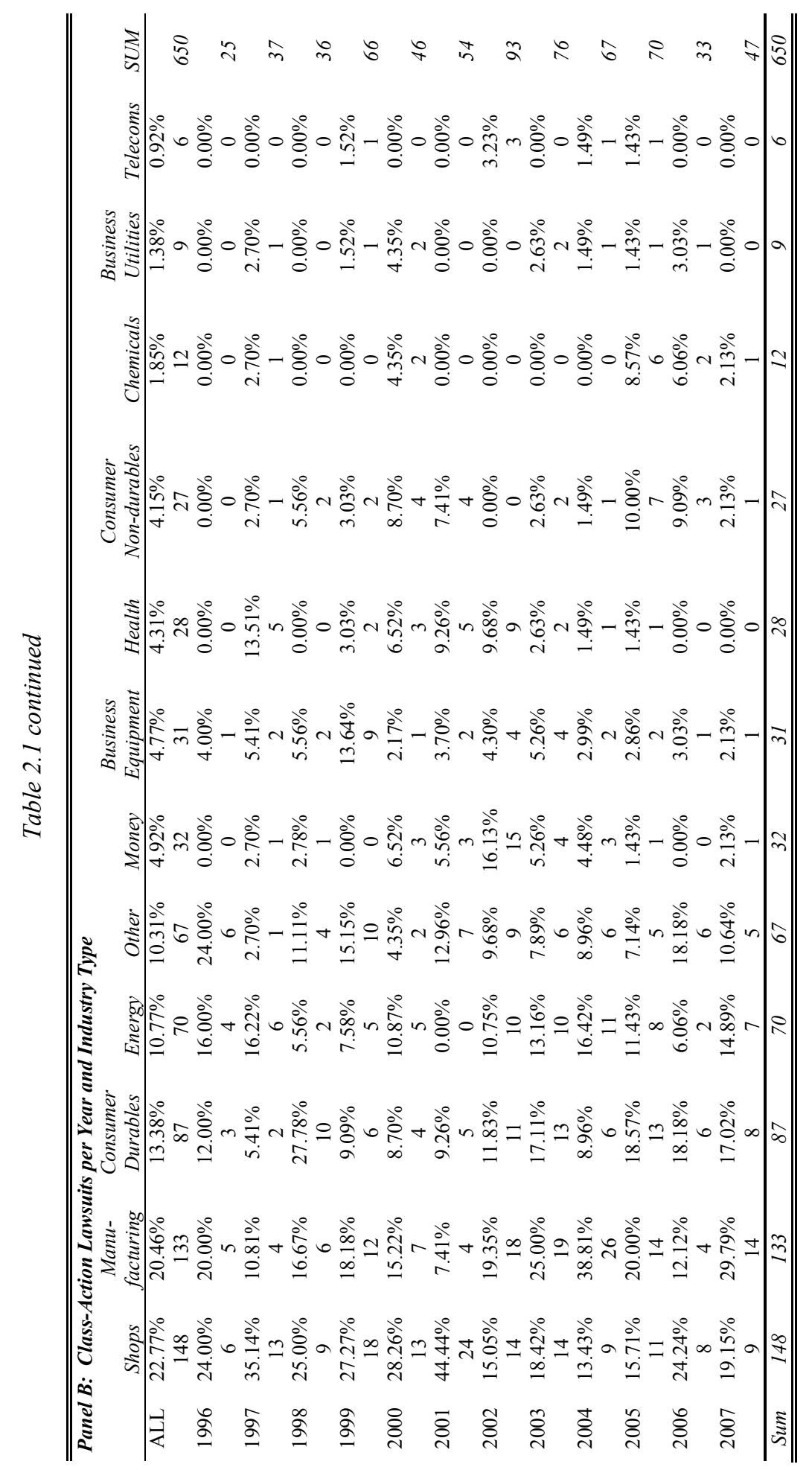




\subsubsection{Testable Hypotheses}

We test whether class-action lawsuits have long-term disciplining effects on the CEO and the firm. Shareholders use class-action lawsuits as a punishing device in response to underperformance and managerial malfeasance. We hypothesize that shareholder wealth effects (both over short and long horizons) differ between the types of allegation brought forward. If stock price performance does not recover from a short-term dip, then investors that sue a firm are better off to dispose of their shares and to take the settlement amount only instead of holding on to their shares. According to Fich and Shivdasani (2007), an out-of-court settlement is proposed in $91 \%$ of the cases. Out of these settlements, the amounts range between $\$ 3$ and $\$ 40$ million for the $25^{\text {th }}$ and $75^{\text {th }}$ percentile, respectively, whereas the average settlement amounts to $\$ 22$ million. If performance recovers and outperforms the market after adjusting for risk over long-horizons, then the lawsuit has merits beyond the settlement amount that the plaintiffs originally aimed for. Long-term stock performance is highly sensitive to the type of allegations that the corporation faces. We discriminate between unlawful activities, which are likely to systematically affect the whole entity (violation of duty of care) versus allegations charging individuals (violations of duty of loyalty). We argue that individuals are more likely to be disciplined for their behavior than the whole firm as a legal entity. In the case of a whole firm, a lawsuit filing is a more disruptive and adverse event, which sustainably erodes investor confidence. For this group of firms, we hypothesize a significant long-term underperformance rather than for a group of firms, where individuals are charged for a violation of duty of loyalty. This reasoning results in the following hypothesis.

H1: Only firms, whose individual directors are charged with violation of duty of loyalty, experience a disciplining effect from lawsuits. This translates into long-term reversal.

Additionally, we test whether class-action lawsuits have similar negative stock price effects irrespective of whether the firm was already facing problems before the filing date - a triggering event such as voluntary self-disclosure. The filing of a lawsuit therefore resembles a material loss of investor confidence, which manifests itself as an inferior stock price performance. In this case, we hypothesize that it is the actual filing of the lawsuit that causes long-term performance effects rather than self-disclosure before the filing.

H2: Long-term stock price performance will not differ between firms where adverse events trigger the filing of a lawsuit and firms, where such pre-lawsuit events are absent. 
For our last hypothesis, we compare findings from the long-term performance of the firm's equity to the possible expected costs, and to the firm's outstanding debt. We represent this comparison with firms' expected frequency of default. If any possible recovery of the share price subsequent to litigation comes at the expense of a significant increase in this variable, then we conclude that there is a wealth transfer from creditors to shareholders. We state that class-action lawsuits can only work as governance mechanisms and disciplining devices if such a wealth transfer is absent. In this case, performance reversal is a result of either management turnover or a change in behavior.

H3: Performance reversals originate in a wealth transfer from creditors to shareholders.

\subsection{Long-Term Wealth Effects in Class-Action Lawsuits}

We adopt several methods in order to evaluate shareholder wealth effects from class-action lawsuit filings. Our general approach is the use of event studies, but for different purposes. We evaluate short-term announcement effects of classaction lawsuit filings with daily returns in the classic style of Brown and Warner (1980). For longer horizons up to 36 months we use monthly data. We also propose the implementation of calendar time portfolio returns with a Fama-French risk correction according to Kothari and Warner (2007) and others. We further suggest the importance of augmenting the risk correction with a momentum factor according to Carhart (1997). Subsection 3.5 examines a possible wealth transfer from creditors to shareholders in the form of a higher probability of default.

\subsubsection{Short-Term Announcement Effect}

The cumulative abnormal returns in Figure 2.1 best depict the immediate stock price reaction of a class-action lawsuit filing. Using various types of methods, we document a unanimous decline in stock price on the filing of a class-action lawsuit. More importantly, we already see a significant dip in stock prices before the actual filing, which points at either rumors hitting the market or repercussions from triggering events.

Besides the sharp stock price drop, we also fail to observe a significant recovery within two months following the event (up to 40 trading days). This finding already hints at the importance of analyzing long-term shareholder wealth effects. Short-term wealth effects can be documented as being quite substantial. Even though we see a recovery of 200-300bp from shortly after the filing until day 
40, the cumulative abnormal returns over the whole event window are constantly negative. This robustness in negative performance stems from the almost monotonous decrease in stock price before the filing date. We could attribute the sharp decline in stock prices before the event day purely to triggering events. But, in Figure 2.2, we split the sample into firms where a triggering event has preceded the filing of the lawsuit versus those firms where it has not, and compare the shapes of the graphs. In the graph, it becomes clearly visible that firms where a triggering event has preceded the filing are not the only cases with a pre-event day decline in performance. Though somewhat weaker in magnitude, firms' share price performance declines correspondingly before the event if a lawsuit comes as a surprise to the market.

This case implies that we are not purely examining firms that have already suffered from adverse events before the lawsuit. Our findings are robust to all types of specifications in event study methods. We obtain qualitatively similar results using equally-weighted benchmarks. An attractive property of event studies that uses the Fama-French two-step procedure is that we can use the estimated coefficients and their loadings on the factors from the estimation period of daily return data. We use these coefficients for the computations of the expected returns during the event window in order to further characterize sued companies by their factor loadings. We do so to distinguish between firms by their magnitude of exposure to conventional risk factors.

In Table 2.2 we further break down the sample by the types of allegation that each firm faces in court. Firms being accused of accounting fraud (Panel C) have by far the lowest loading on HML, which we interpret as these being extremely high growth firms before the filing. This stellar growth might be fueled by allegedly wrong accounting data. Similarly, firms facing insider trading (Panel E) allegations have a negative exposure to small firm risk (SMB coefficient of -0.98). This observation can be due to the fact that directors and officers in larger capitalized firms have steeper incentives (Core, Holthausen, and Larcker, 1999). That is, if directors and officers can capture more upside potential from inside information, they are also more likely to use it. Overall (Panel A), one can conclude that sued firms are growth firms, which tend to be large. The latter is consistent with the literature on litigation, which states that shareholders target companies with deep pockets. In Subsection 3.4 we investigate whether these coefficients experience a transformation and whether stock characteristics change subsequent to the litigation. 


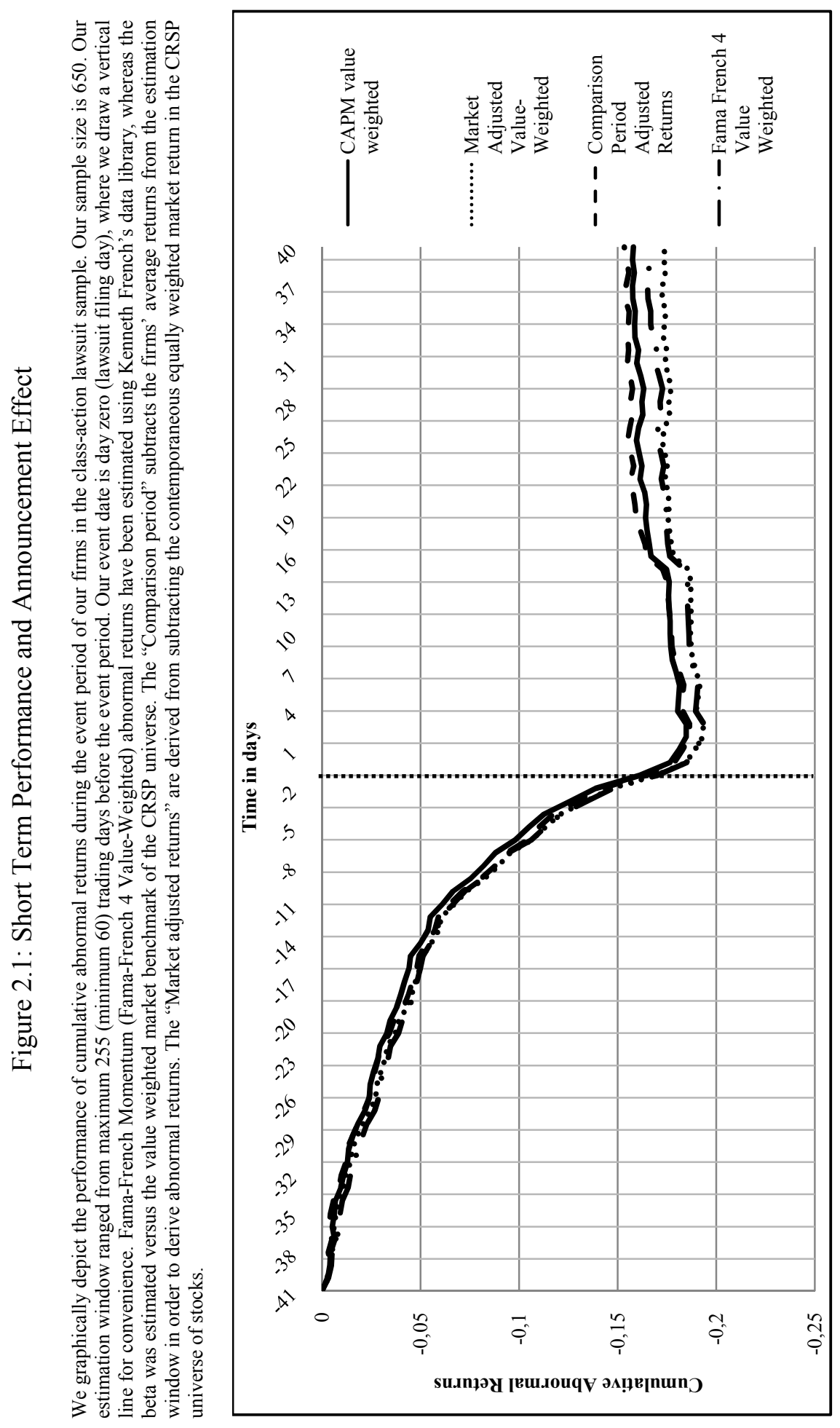




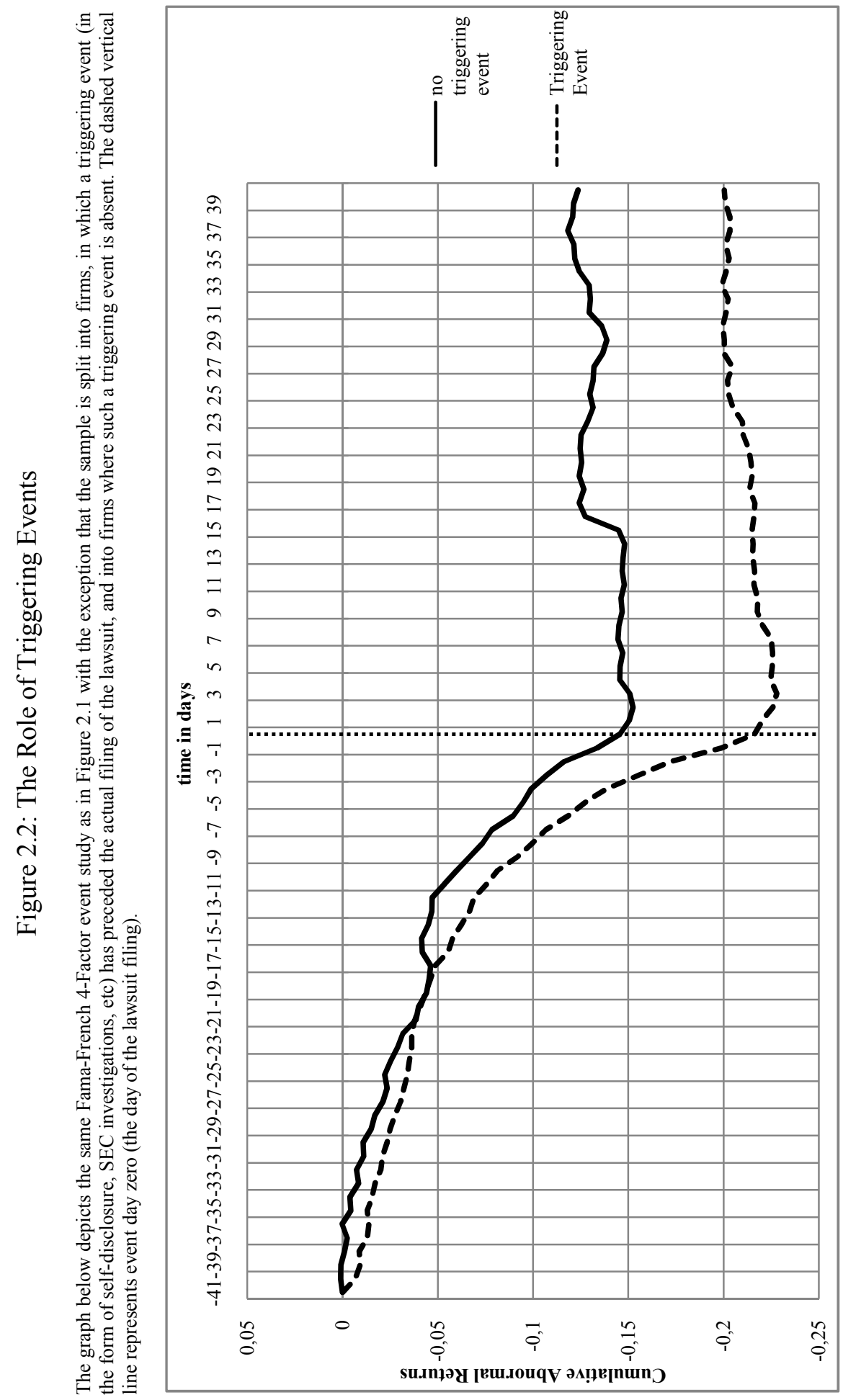


As a next step to distinguish between allegation types we look at the same subsamples but during five separate event windows. Table 2.3 uses five different event windows from $(-1 ;+1)$ to $(-10 ;+10)$. Since average abnormal returns are likely to be affected by extreme values (upward or downward), we also report median values in parentheses to be more conservative. We check for statistical significance of difference of mean (median) values from zero with t-statistics (Wilcoxon).

In Panel A, we can observe that "illegal business practices" show the most negative abnormal returns in all settings. Allegations, which are governance- or compensation-related (similar for "insider trading") also result in a nontrivial negative announcement return. Over longer horizons abnormal returns become increasingly negative. We explain these findings by shareholders losing confidence in the firm they invest in as soon as corporate governance failures or a manager taking advantage of private knowledge is disclosed to the investing public. In Panel $\mathrm{B}$, we highlight that for several event windows the stock price reaction to an increasingly severe lawsuit (approximated by the number of allegations brought forward) becomes more negative. We conclude that a more negative stock price reaction with more allegations brought forward can yield harsher personal consequences for the CEO and for the firm. If we focus on the first three rows (up to three allegations), the picture of decreasing cumulative returns is consistent among all event windows

\section{Table 2.2: Exposure to Risk Factors during Estimation Period}

In the table below, we depict the statistics of the exposures to the Fama-French risk factors and Momentum. Panels B to H comprise different types of allegations. The market benchmark for beta is the equally weighted CRSP universe of stocks. For details on the construction of the variables, please refer to Kenneth French's website: http://mba.tuck.dartmouth.edu/pages/faculty/ken.french/data_library.html.

\begin{tabular}{|c|c|c|c|c|c|c|}
\hline & Mean & Median & Std. Dev. & Max. & Min. & $\mathbf{N}$ \\
\hline \multicolumn{7}{|c|}{ Panel A: Entire Class-Action Lawsuit Sample } \\
\hline BETA & $1.307 * * *$ & $1.290 * * *$ & 0.601 & 4.100 & -1.060 & 649 \\
\hline SMB & $-0.562 * * *$ & $-0.440 * * *$ & 1.100 & 2.990 & -5.210 & 649 \\
\hline HML & $-0.433 * * *$ & $-0.510 * * *$ & 0.675 & 1.920 & -1.980 & 649 \\
\hline UMD & -0.032 & 0.030 & 0.696 & 2.280 & -3.420 & 649 \\
\hline \multicolumn{7}{|c|}{ Panel B: Stock Price Manipulation } \\
\hline BETA & $1.267 * * *$ & $1.260 * * *$ & 0.596 & 3.110 & -1.060 & 327 \\
\hline SMB & $-0.625 * * *$ & $-0.460 * * *$ & 1.159 & 2.050 & -5.210 & 327 \\
\hline HML & $-0.351 * * *$ & $-0.460 * * *$ & 0.676 & 1.920 & -1.980 & 327 \\
\hline UMD & -0.043 & 0.020 & 0.750 & 2.280 & -3.120 & 327 \\
\hline \multicolumn{7}{|c|}{ Panel C: Accounting Fraud } \\
\hline BETA & $1.486^{* * *}$ & $1.435 * * *$ & 0.566 & 2.900 & -0.180 & 92 \\
\hline SMB & $-0.457 * * *$ & $-0.445 * * *$ & 1.007 & 1.970 & -4.830 & 92 \\
\hline HML & $-0.705 * * *$ & $-0.790 * * *$ & 0.615 & 1.060 & -1.960 & 92 \\
\hline UMD & 0.071 & $0.130 *$ & 0.449 & 1.270 & -1.140 & 92 \\
\hline \multicolumn{7}{|c|}{ Panel D: Illegal Business Practices } \\
\hline BETA & $1.342 * * *$ & $1.360 * * *$ & 0.547 & 3.140 & -0.410 & 217 \\
\hline SMB & $-0.516^{* * *}$ & $-0.330 * * *$ & 1.103 & 2.050 & -4.630 & 217 \\
\hline
\end{tabular}




\begin{tabular}{|c|c|c|c|c|c|c|}
\hline HML & $-0.286 * * *$ & $-0.390 * * *$ & 0.678 & 1.920 & -1.710 & 217 \\
\hline UMD & -0.065 & -0.060 & 0.643 & 1.540 & -2.360 & 217 \\
\hline \multicolumn{7}{|c|}{ Panel E: Insider Trading } \\
\hline BETA & $1.208 * * *$ & $1.235 * * *$ & 0.670 & 2.970 & -1.060 & 128 \\
\hline SMB & $-0.980 * * *$ & $-0.665 * * *$ & 1.272 & 1.290 & -5.210 & 128 \\
\hline HML & $-0.412 * * *$ & $-0.510 * * *$ & 0.630 & 0.910 & -1.980 & 128 \\
\hline UMD & -0.086 & -0.005 & 0.744 & 1.780 & -3.120 & 128 \\
\hline \multicolumn{7}{|c|}{ Panel F: False and Misleading Statements } \\
\hline BETA & $1.250 * * *$ & $1.210 * * *$ & 0.576 & 4.100 & -0.660 & 393 \\
\hline SMB & $-0.569 * * *$ & $-0.480 * * *$ & 1.102 & 2.060 & -4.830 & 393 \\
\hline HML & $-0.447 * * *$ & $-0.530 * * *$ & 0.649 & 1.720 & -1.980 & 393 \\
\hline UMD & -0.014 & 0.040 & 0.679 & 2.280 & -2.860 & 393 \\
\hline \multicolumn{7}{|c|}{ Panel G: IPO/SEO/Acquisition related } \\
\hline BETA & $1.275 * * *$ & $1.240 * * *$ & 0.566 & 2.710 & -0.040 & 92 \\
\hline SMB & $-0.355 * * *$ & $-0.265 * * *$ & 0.953 & 2.050 & -4.340 & 92 \\
\hline HML & $-0.414 * * *$ & $-0.545^{* * *}$ & 0.648 & 1.540 & -1.710 & 92 \\
\hline UMD & 0.009 & 0.040 & 0.635 & 2.180 & -3.120 & 92 \\
\hline \multicolumn{7}{|c|}{ Panel H: Governance violations } \\
\hline BETA & $1.451 * * *$ & $1.390 * * *$ & 0.548 & 3.140 & 0.330 & 127 \\
\hline SMB & $-0.398 * * *$ & $-0.450 * * *$ & 1.009 & 1.970 & -4.340 & 127 \\
\hline HML & $-0.325 * * *$ & $-0.440 * * *$ & 0.732 & 1.540 & -1.840 & 127 \\
\hline UMD & -0.071 & -0.090 & 0.669 & 2.180 & -2.150 & 127 \\
\hline
\end{tabular}

In order to determine which allegations drive the return during our event periods, we conduct a cross-sectional regression of our event window cumulative abnormal returns on a number of control variables and dummies of the types of allegations with "stock price manipulations" as the base level. We also control for firm characteristics, which are shown to drive abnormal returns (Campbell, Lo, and MacKinley, 1997). Because all of our firms in the sample are experiencing an event, we need a base level of allegations to compare results to. Allegation dummies are included multivariately and the correlation between them does not exceed 0.32 . Results are reported in the table below.

In a multivariate setting, we still observe that "illegal business practices" results in significantly lower CAR than for the base case, especially for very short run event windows. For "insider trading" however, the pattern is reversed. Coefficients on control variables like firm size (log of total assets) and growth opportunities (log of market-to-book ratio) are in line with the event study literature. The latter as a control variable is consistently negative pointing at a short-term correction to fundamental values. Firm size has a mitigating effect on abnormal returns because larger firms are more likely to be diversified and have a larger shareholder base. After controlling for other factors, allegations of this type do not result in significantly lower CARs than in the base case. Still, for longer periods, they bear more negative announcement returns. 


\section{Table 2.3: Cumulative Average Abnormal Returns}

Panel A in the table below investigates the same abnormal return windows for the seven types of allegations, which have already been defined in Table 2.1. Note that these types of allegations are not mutually exclusive. For the event study, we require an estimation period window of at least 60 trading days and a maximum of 255 for the estimation of $R_{m}-R_{f}, H M L, S M B$, and Momentum coefficients. Day zero is defined as the day of the class-action lawsuit filing. In Panel B, we distinguish between the numbers of allegations that have been filed in the lawsuit. Median values are reported in parentheses. We report significance levels for a test (t-stat for mean and z-stat for median) for abnormal returns different from zero at 10,5 , and $1 \%$ level with *,**, and ***, respectively.

Panel A: Abnormal Return per Allegation Type

\begin{tabular}{|c|c|c|c|c|c|c|}
\hline $\begin{array}{l}\text { Type of Allegation } \\
\text { brought forward }\end{array}$ & $(-1,+1)$ & $(-1,0)$ & $(0,+1)$ & $(-5,+5)$ & $(-10,+10)$ & $\mathrm{N}$ \\
\hline Average of all & $-4.33 \% * * *$ & $-3.86 \% * * *$ & $-2.03 \% * * *$ & $-8.52 \% * * *$ & $-11.57 \% * * *$ & 648 \\
\hline allegations & $(-1.07 \%) * * *$ & $(-0.89 \%) * * *$ & $(-0.63 \%) * * *$ & $(-4.22 \%) * * *$ & $(-5.74 \%) * * *$ & \\
\hline Stock price & $-5.17 \% * * *$ & $-4.65 \% * * *$ & $-2.53 \% * * *$ & $-8.80 \% * * *$ & $-13.46 \% * * *$ & 327 \\
\hline manipulation & $(-1.49 \%)^{* * *}$ & $(-1.17 \%)^{* * *}$ & $(-0.85 \%)^{* * *}$ & $(-4.52 \%)^{* * *}$ & $(-7.71 \%)^{* * *}$ & \\
\hline Accounting & $-2.99 \% * * *$ & $-2.43 \% * *$ & $-1.11 \% *$ & $-5.69 \% * * *$ & $-6.44 \% * * *$ & 92 \\
\hline Fraud & $(-0.43 \%)$ & $(-0.58 \%)$ & $(0.11 \%)$ & $(-3.44 \%)^{* * *}$ & $(-3.80 \%)^{* * *}$ & \\
\hline Illegal Business & $-6.87 \% * * *$ & $-5.95 \% * * *$ & $-3.56 \% * * *$ & $-12.64 \% * * *$ & $-14.17 \% * * *$ & 217 \\
\hline Practices & $(-2.41 \%)^{* * *}$ & $(-1.89 \%)^{* * *}$ & $(-1.30 \%)^{* * *}$ & $(-6.12 \%)^{* * *}$ & $(-7.29 \%)^{* * *}$ & \\
\hline Insider & $-4.91 \% * * *$ & $-4.39 \% * * *$ & $-2.23 \% * *$ & $-9.44 \% * * *$ & $-14.22 \% * * *$ & 127 \\
\hline Trading & $(-1.42 \%)^{* * *}$ & $(-1.46 \%)^{* * *}$ & $(-0.32 \%)^{* *}$ & $(-4.20 \%)^{* * *}$ & $(-5.26 \%)^{* * *}$ & \\
\hline False/misleading & $-3.86 \% * * *$ & $-3.86 \% * * *$ & $-1.71 \% * * *$ & $-8.79 \% * * *$ & $-12.96 \% * * *$ & 392 \\
\hline statements & $(-0.67 \%)^{* * *}$ & $(-0.83 \%)^{* * *}$ & $(-0.56 \%)^{* * *}$ & $(-4.00 \%) * * *$ & $(-6.92 \%)^{* * *}$ & \\
\hline $\mathrm{SEO} / \mathrm{IPO} /$ & $-2.78 \% * *$ & $-2.90 \% * * *$ & $-1.26 \% *$ & $-2.64 \%$ & $-3.94 \%$ & 92 \\
\hline $\begin{array}{l}\text { Acquisition- } \\
\text { related }\end{array}$ & $(-0.31 \%)$ & $(-0.87 \%)^{* *}$ & $(-0.59 \%)$ & $(-1.30 \%)$ & $(-2.14 \%)$ & \\
\hline Governance & $-4.58 \% * * *$ & $-3.73 \% * * *$ & $-1.55 \% * *$ & $-9.42 \% * * *$ & $-10.65 \% * * *$ & 128 \\
\hline Problems & $(-1.00 \%)^{* * *}$ & $(-0.82 \%)^{* * *}$ & $(-0.45 \%)^{* *}$ & $(-3.30 \%)^{* * *}$ & $(-4.43 \%)^{* * *}$ & \\
\hline
\end{tabular}

Panel B: Average Abnormal Returns per Total Number of Allegations Brought Forward

\begin{tabular}{ccccccc}
\hline \hline $\begin{array}{l}\text { Total } \# \text { of } \\
\text { Allegations }\end{array}$ & $(-1,+1)$ & $(-1,0)$ & $(0,+1)$ & $(-5,+5)$ & $(-10,+10)$ & $\mathrm{N}$ \\
\hline 1 & $-2.92 \% * * *$ & $-2.37 \% * * *$ & $-1.73 \% * * *$ & $-7.35 \% * * *$ & $-9.42 \% * * *$ & 167 \\
& $(-0.32 \%)$ & $(-0.27 \%)$ & $(-0.42 \%)$ & $(-3.56 \%)^{* * *}$ & $(-4.75 \%)^{* * *}$ & \\
2 & $-4.47 \% * * *$ & $-3.97 \% * * *$ & $-1.95 \% * * *$ & $-8.61 \% * * *$ & $-11.76 \% * * *$ & 268 \\
& $(-1.34 \%)^{* * *}$ & $(-1.19 \%)^{* * *}$ & $(-0.79 \%)^{* * *}$ & $(-4.63 \%)^{* * *}$ & $(-6.54 \%)^{* * *}$ & \\
\multirow{2}{*}{3} & $-5.83 \% * *$ & $-5.28 \% * * *$ & $-2.54 \% * * *$ & $-9.52 \% * * *$ & $-13.74 \% * * *$ & 169 \\
& $(-1.74 \%)^{* * *}$ & $(-1.49 \%)^{* * *}$ & $(-0.45 \%)^{* *}$ & $(-4.23 \%)^{* * *}$ & $(-6.79 \%)^{* * *}$ & \\
\multirow{2}{*}{4} & $-3.20 \%$ & $-2.77 \%$ & $-2.22 \%$ & $-9.28 \% *$ & $-11.42 \% *$ & 34 \\
& $(-0.95 \%)$ & $(-0.50 \%)$ & $(-0.92 \%)$ & $(-3.66 \%)^{*}$ & $(-3.91 \%)$ & \\
\multirow{2}{*}{5} & $-5.38 \%$ & $-9.19 \%$ & $-1.68 \%$ & $-10.43 \%$ & $-9.82 \%$ & 5 \\
& $(0.70 \%)$ & $(-0.12 \%)$ & $(-0.19 \%)$ & $(-3.77 \%)$ & $(-5.25 \%)$ & \\
\hline \hline
\end{tabular}




\section{Table 2.4: Cross-Sectional Regressions and Single Allegations}

In Panel A below, we report coefficients from cross-sectional regressions of the abnormal returns from the five different event windows. Every regression controls for return on assets (ROA), growth opportunities (Log MB), size (Log TA), change in sales over the prior calendar year, change in stock price over the calendar fiscal year, whether the firm is a dividend paying firm, and for industry- (FamaFrench 12) and year effects. The $t$-statistics are reported in parentheses and significance is indicated with $*$, **, and *** for the 10, 5, and 1\% level, respectively. In Panel B, we restrict our sample to those firms only facing one allegation to isolate overlapping effects between non-mutually exclusive allegations. We report significance levels for tests of mean and median (in parentheses) being different from zero with the same annotation.

Panel A: Cross-sectional Regression of Cumulative Abnormal Return over Different Event Windows on Control Variables

\begin{tabular}{|c|c|c|c|c|c|}
\hline $\begin{array}{l}\text { type of } \\
\text { allegation }\end{array}$ & $(-1,+1)$ & $(-1,0)$ & $(0,+1)$ & $(-5,+5)$ & $(-10,+10)$ \\
\hline \multicolumn{6}{|l|}{ Control Variables } \\
\hline $\mathrm{ROA}$ & $\begin{array}{c}-0.0200 \\
(-0.6655)\end{array}$ & $\begin{array}{c}0.0006 \\
(0.0207)\end{array}$ & $\begin{array}{c}-0.0196 \\
(-0.9549)\end{array}$ & $\begin{array}{c}-0.0079 \\
(-0.1537)\end{array}$ & $\begin{array}{c}-0.0095 \\
(-0.1616)\end{array}$ \\
\hline $\log M B$ & $\begin{array}{c}-0.0379 * * * \\
(-3.1754)\end{array}$ & $\begin{array}{c}-0.0419 * * * \\
(-3.8359)\end{array}$ & $\begin{array}{c}-0.0189 * * \\
(-2.3249)\end{array}$ & $\begin{array}{c}-0.0742 * * * \\
(-3.6638)\end{array}$ & $\begin{array}{c}-0.0731 * * * \\
(-3.1553)\end{array}$ \\
\hline Log TA & $\begin{array}{c}-0.0027 \\
(-0.7437)\end{array}$ & $\begin{array}{c}-0.0029 \\
(-0.8745)\end{array}$ & $\begin{array}{c}-0.0020 \\
(-0.8103)\end{array}$ & $\begin{array}{c}0.0042 \\
(0.6806)\end{array}$ & $\begin{array}{c}0.0166^{* *} \\
(2.3214)\end{array}$ \\
\hline Change in Sales & $\begin{array}{c}0.0333 \\
(1.1526)\end{array}$ & $\begin{array}{c}0.0108 \\
(0.4079)\end{array}$ & $\begin{array}{c}0.0421 * * \\
(2.1426)\end{array}$ & $\begin{array}{c}0.0568 \\
(1.1586)\end{array}$ & $\begin{array}{c}0.0505 \\
(0.8993)\end{array}$ \\
\hline Change in Price & $\begin{array}{c}0.0514^{* * *} \\
(3.4202)\end{array}$ & $\begin{array}{c}0.0423 * * * \\
(3.0748)\end{array}$ & $\begin{array}{c}0.0283 * * * \\
(2.7610)\end{array}$ & $\begin{array}{l}0.0506 * * \\
(1.9809)\end{array}$ & $\begin{array}{c}0.0836 * * * \\
(2.8616)\end{array}$ \\
\hline Dividend Payer & $\begin{array}{c}0.0193 \\
(1.2744) \\
\end{array}$ & $\begin{array}{c}0.0168 \\
(1.2093) \\
\end{array}$ & $\begin{array}{c}0.0001 \\
(0.0054) \\
\end{array}$ & $\begin{array}{c}-0.0074 \\
(-0.2864) \\
\end{array}$ & $\begin{array}{c}-0.0465 \\
(-1.5750) \\
\end{array}$ \\
\hline $\begin{array}{l}\text { Allegation types } \\
\text { Base: Stock price } \\
\text { manipulation }\end{array}$ & & & & & \\
\hline Accounting & 0.0042 & 0.0012 & 0.0093 & 0.0109 & $(0.0222$ \\
\hline Fraud & $(0.2189)$ & $(0.0679)$ & $(0.7112)$ & $(0.3352)$ & $(0.5972)$ \\
\hline Illegal Business & $-0.0296 * *$ & $-0.0328 * * *$ & -0.0132 & $-0.0593 * * *$ & -0.0300 \\
\hline Practices & $(-2.2757)$ & $(-2.7609)$ & $(-1.4916)$ & $(-2.6914)$ & $(-1.1885)$ \\
\hline Insider & 0.0175 & 0.0107 & $0.0175^{*}$ & -0.0056 & -0.0304 \\
\hline Trading & (1.2037) & $(0.8062)$ & $(1.7680)$ & $(-0.2256)$ & $(-1.0778)$ \\
\hline False/misleading & -0.0001 & -0.0154 & 0.0077 & -0.0297 & $-0.0516^{* *}$ \\
\hline statements & $(-0.0077)$ & $(-1.2380)$ & $(0.8285)$ & $(-1.2861)$ & $(-1.9556)$ \\
\hline SEO/IPO/ & -0.0013 & -0.0091 & -0.0020 & 0.0443 & $0.0759 * *$ \\
\hline Acquisition rel. & $(-0.0782)$ & $(-0.5954)$ & $(-0.1771)$ & $(1.5628)$ & $(2.3395)$ \\
\hline Governance & -0.0025 & -0.0077 & 0.0119 & -0.0199 & -0.0119 \\
\hline Problems & $(-0.1657)$ & $(-0.5521)$ & $(1.1458)$ & $(-0.7649)$ & $(-0.3994)$ \\
\hline Industry controls & $\mathrm{Y}$ & $\mathrm{Y}$ & $\mathrm{Y}$ & $\mathrm{Y}$ & $\mathrm{Y}$ \\
\hline Year Controls & Y & $\mathrm{Y}$ & $\mathrm{Y}$ & $\mathrm{Y}$ & Y \\
\hline Adjusted $\mathrm{R}^{2}$ & 0.0900 & 0.0930 & 0.0525 & 0.0936 & 0.1460 \\
\hline $\mathrm{N}$ & 512 & 512 & 512 & 512 & 512 \\
\hline
\end{tabular}


Panel B: Average CARs of the Subsample of Firms with only one Allegation $(N=167)$

\begin{tabular}{lcccccc}
\hline \hline $\begin{array}{l}\text { type of } \\
\text { allegation }\end{array}$ & $(-1,+1)$ & $(-1,0)$ & $(0,+1)$ & $(-5,+5)$ & $(-10,+10)$ & $N$ \\
\hline Stock price & $-3.43 \%$ & $-0.83 \%$ & $-4.88 \%{ }^{* *}$ & $-10.21 \% * *$ & $-12.93 \% * *$ & 13 \\
manipulation & $(-3.51 \%)^{* *}$ & $(-1.17 \%)$ & $(-2.86 \%)^{* *}$ & $(-6.68 \%)^{*}$ & $(-8.48 \%)^{*}$ & \\
Accounting & $0.28 \%$ & $0.42 \%$ & $0.50 \%$ & $-2.60 \%$ & $-2.93 \%$ & 28 \\
Fraud & $(0.30 \%)$ & $(0.04 \%)$ & $(0.48 \%)$ & $(-4.24 \%)^{*}$ & $(-2.12 \%)^{*}$ & \\
Illegal Business & $-8.14 \% * *$ & $-6.76 \% *$ & $-3.54 \%$ & $-15.91 \% * *$ & $-13.06 \% * *$ & 20 \\
Practices & $(-2.08 \%)$ & $(-0.84 \%)$ & $(-0.52 \%)$ & $(-5.77 \%)^{* *}$ & $(-5.99 \%)$ & \\
Insider & $-2.27 \%$ & $-1.05 \%$ & $-3.56 \%$ & $7.34 \%$ & $-13.38 \%$ & 1 \\
Trading & $(-2.27 \%)$ & $(-1.05 \%)$ & $(-3.56 \%)$ & $(7.34 \%)$ & $(-13.38 \%)$ & \\
False/misleading & $-2.42 \% * *$ & $-2.53 \% * *$ & $-1.32 \%$ & $-6.76 \% * * *$ & $-10.20 \% * * *$ & 96 \\
statements & $(0.23 \%)$ & $(0.02 \%)$ & $(-0.29 \%)$ & $(-1.74 \%)$ & $(-4.37 \%)^{* *}$ & \\
SEO/IPO/ & NA & NA & NA & NA & NA & 0 \\
Acquisition rel. & NA & NA & NA & NA & NA & \\
Governance & $-6.32 \%$ & $-1.97 \%$ & $-4.62 \%$ & $-6.70 \%$ & $-7.45 \%$ & 8 \\
Problems & $(-2.55 \%)$ & $(-0.94 \%)$ & $(-2.27 \%)$ & $(-6.09 \%)$ & $(-8.25 \%)$ & \\
\hline \hline
\end{tabular}

We stress that allegations are not mutually exclusive. Hence, overlap between the allegation types might blur our conclusions. In order to isolate overlapping effects of allegations, we have to proceed differently. For that purpose we also focus on the group of firms (167 in total) that only face one single allegation and distinguish between those. We stick to a univariate analysis of mean and median values. Thus, we are able to isolate the allegation types from each other so that we can discriminate more easily. For those 20 firms being charged with illegal business practices only, CARs during event windows $[-5 ;+5]$ and $[-10 ;+10]$ turn out to be quite significant with -16 and $-13 \%$, respectively. Insider trading is inconclusive because it almost constantly coincides with an allegation of either stock price manipulation and/or false and misleading statements. Therefore the sample size is consequently very low, which does not allow for statistically reliable inferences. We conclude significant differences in terms of shareholder wealth effects between the allegations brought forward, which gives first indications on our test of $H 1$.

\subsubsection{Long Horizon Results}

In Subsection 3.1, we were not able to observe a clear pattern of short-term (two months) recovery of the stock price for firms being sued. To gain more insights into this result, we conduct the same analysis using monthly data and an event window of up to 36 months. We graphically depict the evolvement of monthly cumulative abnormal returns in Figure 2.3 using several methods. 
The development from the event month zero until month three approximately confirms the image from Figure 2.1, namely an indication of a slight recovery of the stock price, which sharply reverses thereafter. After month three we see a gradual decline down to a minimum of $-23 \%$ CAR over less than three years. For the entire sample of 650 sued firms (irrespective of allegation type) this is quite puzzling. On average, shareholder litigation does not seem to pay off in terms of stock price recovery. If we take the statistical validity in this case for granted, we can infer that shareholders aim for the settlement amount and dispose of any equity share in the company that they sued in the first place. However, we acknowledge potential statistical biases for this type of analysis. Still this preliminary result can serve as a crude indication of long-term shareholder wealth effects.

\subsubsection{Abnormal Returns in Calendar Time}

Long horizon event studies are not unproblematic with respect to statistical validity since potential misspecification of daily expected returns accumulates over long horizons to sizable estimation errors. Moreover cross-correlation becomes greater over long horizons (Kothari and Warner, 2007). The buy-and-hold abnormal return (BHAR) approach by Daniel, Grinblatt, Titman, and Wermers (1997) therefore uses matching firms/portfolios to calculate abnormal return for each firm and holding period $t$. Here, risk-adjustment takes place via characteristic-based measures. The difficulty in using this approach is that it is not a feasible investment approach because the total number of event firms is not known in advance (Eckbo, Masulis, and Norli, 2000). So, if we want to compute long-term shareholder wealth effects from the time of the filing date and how these shareholders perform on a riskadjusted basis compared to the market and conventional risk factors, we need to proceed differently.

Instead, we suggest the implementation of a calendar time portfolio approach (Fama, 1998), which works the following way. Suppose a group of firms experience some common corporate event. In the sample period, firms are facing events that might be spread over time ( $T=$ months).

Further assume that we want to compute price performance over period $T$ following the occurrence. To do so, in each calendar month over the entire sample period, we construct a portfolio containing securities that experience an event during the previous time $T$. Due to the nature of the construction, the number of firms in the portfolio is not constant: firms exit and new firms enter each month. In this way, we account for all the cross-correlations of event firm abnormal returns in the portfolio variance. The net of risk computation of abnormal returns takes place differently. We regress the resulting time series of monthly returns on the Fama-French factors plus a momentum factor (Carhart, 1997). 


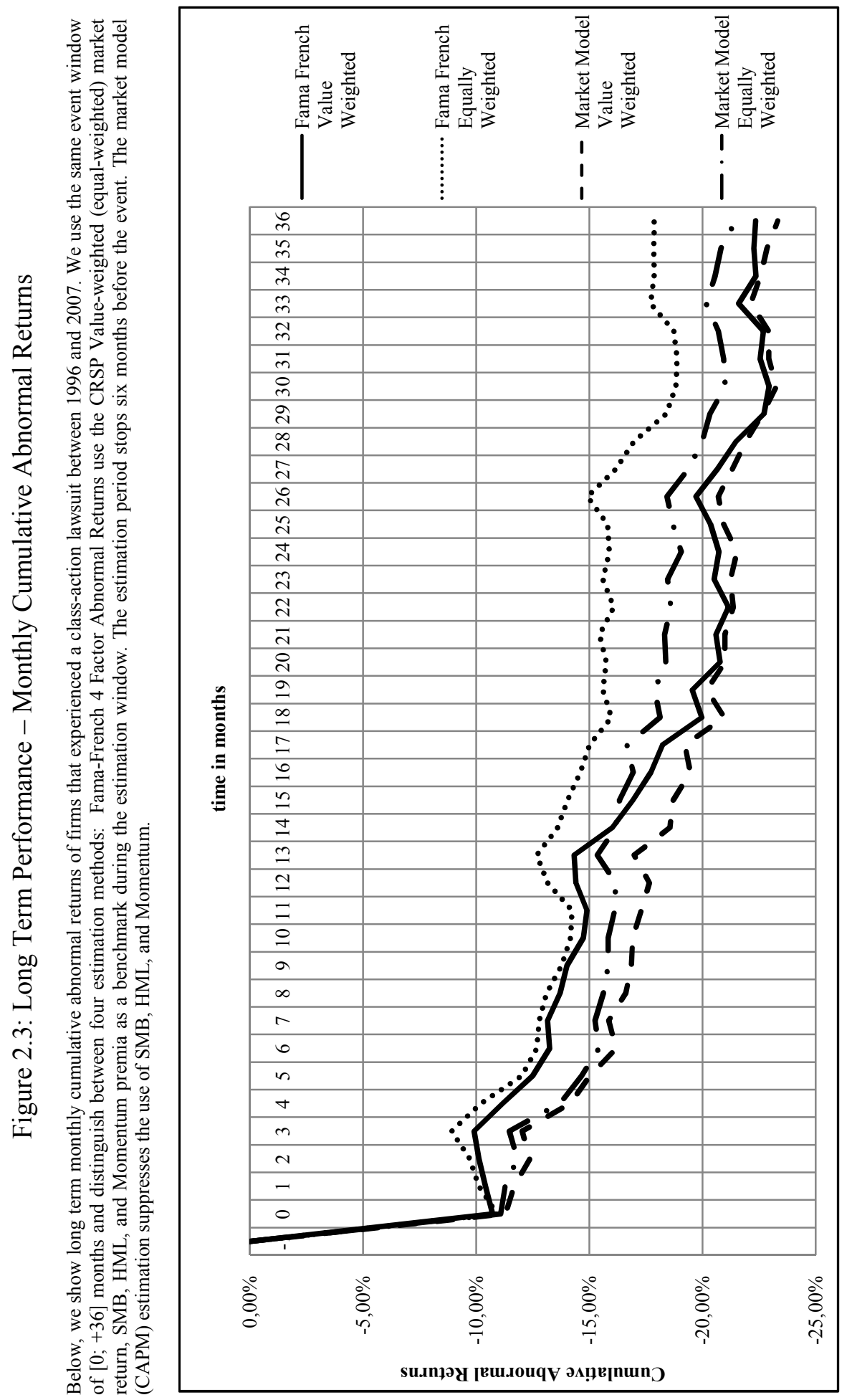


$R_{p t}-R_{f t}=a_{p}+b_{p} *\left(R_{m t}-R_{f t}\right)+s_{p} * \mathrm{SMB}_{t}+h_{p} * \mathrm{HML}_{t}+u_{p} * \mathrm{UMD}_{t}+e_{p t .}$

Where $R_{p t}$ is either the equal or value-weighted return for calendar month $t$ for portfolio $p$, which has experienced an event during the prior time $T, R_{f t}$ is the riskfree rate, and $R_{m t}$ is the return on the CRSP value-weighted market portfolio. The $\mathrm{SMB}_{t}$ is the differential return between a portfolio of small stocks vs. big stocks, $\mathrm{HML}_{t}$ is the return differential between value and growth stocks (high vs. low bookto-market), and $\mathrm{UMD}_{t}$ is the difference in returns between prior year's winners and losers. The critical variable in equation (1) is $a_{p}$, which is the average monthly abnormal return on our portfolio of event firms over the $T$ post event period. The $b_{p}$, $s_{p}, h_{p}$ and $u_{p}$ are the sensitivities to market, small firm risk, the value-premium, and momentum, respectively. Prominent applications of this approach are Mitchell and Stafford (2000) and Brav and Gompers (1997). We adopt seven different holding periods that start from zero to six months and go up to zero to 48 months. This setup reflects that performance does not include the announcement return of the classaction lawsuit filing. The first return of a company being included is always between the end of the filing month and the end of the subsequent month. The results are shown in Table 2.5 below.

It is important to note that our results are highly sensitive to the incorporation of Momentum. ${ }^{4}$ As can be seen in the table, $u_{p}$ is significant and negative on Momentum in all of the regressions, which seems straightforward. Our portfolio is strongly tilted towards prior losers, which, in the light of sued companies' negative performance history, is logical. For Panel A, we note that underperformance diminishes over time after 18 months but still persists. For holding periods of six months, we observe a strongly negative monthly alpha, which translates into an annualized alpha of the investment strategy of almost $-20 \%$. For longer periods, underperformance becomes less negative. Concerning SMB and HML coefficients, we observe a remarkable pattern. The coefficients from the preevent window estimation are still both negative, which hints at sued firms being large firms with low book-to-market ratios (growth firms). After the event however, we note that these turn positive for our portfolio of sued firms. A intermediate conclusion emerging from this observation is that subsequent to their litigation charges, sued companies now behave like smaller and high book-to-market firms (an interpretation could be that these distressed firms are "fallen angels" in the context of Rauh and Sufi, 2009). Hence, not only do we observe a significant effect on stock prices, there is also a change in firm risk with respect to exposures to market factors.

\footnotetext{
${ }^{4}$ Calendar time portfolio regressions using only Fama-French's three-factor model (or CAPM only) are available from the authors upon request.
} 


\section{Table 2.5: Long Term Performance in Calendar Time}

In the table below, we perform Fama-French calendar time portfolio return regressions as advocated by Fama (1998). Panel A uses 132 observations from January 1996 until December 2006. Panel A restricts our sample to the all the companies sued during the time period. Panel B involves firms with lawsuits related to "accounting fraud". In Panel C, the sample is the firms being sued for illegal business practices. Panel D involves firms facing allegations of insider trading. Panel E includes firms with governance problems. Characterizations are illustrated in our Appendix. Our return windows are depicted in row 1 of the table. Alpha represents the intercept of a regression of abnormal returns of a strategy that invests in litigation firms versus the market benchmark, size-, book-to-market and Momentum factors. The dependent variable is the equally weighted monthly percentage return on a portfolio of firms facing litigation during the prior $6,12,18,24,30,36$, or 48 months.

$$
R_{p t}-R_{f t}=a_{p}+b_{p} *\left(R_{m t}-R_{f t}\right)+s_{p} * \mathrm{SMB}_{t}+h_{p} * \mathrm{HML}_{t}+u_{p} * \mathrm{UMD}_{t}+e_{p t}
$$

Where $R_{p t}$ is the return on our portfolio of sued companies, $R_{f t}$ is the risk free rate, $R_{m t}$ is the return on the market. The $S M B$ and $H M L$ capture the size, book to market. The $a$ is the intercept of the regression and the abnormal return of the trading strategy. The $\$, * * *$, and $* * *$ represent significance at the $10,5,1$, and $0.1 \%$ level, respectively. The $t$-statistics (below the coefficients) have been adjusted for heteroskedasticity using the White correction.

\begin{tabular}{|c|c|c|c|c|c|c|c|}
\hline $\begin{array}{l}\text { Panel A: } \\
\text { all Lawsuits } \\
(n=648)\end{array}$ & $\begin{array}{c}{[0 ; 6} \\
\text { months] }\end{array}$ & {$[0 ; 12]$} & {$[0 ; 18]$} & {$[0 ; 24]$} & {$[0 ; 30]$} & {$[0 ; 36]$} & {$[0 ; 48]$} \\
\hline \multicolumn{8}{|l|}{ Parameters } \\
\hline \multirow[t]{2}{*}{ Alpha } & -0.017 & -0.006 & -0.007 & -0.001 & -0.002 & -0.002 & -0.002 \\
\hline & $-4.46 * * *$ & $-1.71^{*}$ & $-2.02 *$ & -0.330 & -0.720 & -0.650 & -0.600 \\
\hline \multirow[t]{2}{*}{ Beta } & 1.305 & 1.256 & 1.213 & 1.058 & 1.089 & 1.117 & 1.133 \\
\hline & $13.10^{* * *}$ & $15.30 * * *$ & $16.92 * * *$ & $9.91 * * *$ & $14.10 * * *$ & $17.64 * * *$ & $19.62 * * *$ \\
\hline \multirow[t]{2}{*}{$S M B$} & 0.617 & 0.558 & 0.554 & 0.489 & 0.578 & 0.597 & 0.598 \\
\hline & $5.00 * * *$ & $5.09 * * *$ & $5.91 * * *$ & $4.37 * * *$ & $7.15 * * *$ & $7.93 * * *$ & $8.13 * * *$ \\
\hline \multirow[t]{2}{*}{$H M L$} & 0.353 & 0.341 & 0.396 & 0.140 & 0.208 & 0.241 & 0.241 \\
\hline & $2.07 *$ & $2.16^{*}$ & $3.28 * * *$ & 0.850 & $1.83 *$ & $2.39 * *$ & $2.42 * *$ \\
\hline$U M D$ & $\begin{array}{c}-0.569 \\
-5.63 * * *\end{array}$ & $\begin{array}{c}-0.516 \\
-5.55 * * *\end{array}$ & $\begin{array}{c}-0.463 \\
-5.97 * * *\end{array}$ & $\begin{array}{c}-0.427 \\
-5.34 * * *\end{array}$ & $\begin{array}{c}-0.414 \\
-5.53 * * *\end{array}$ & $\begin{array}{c}-0.401 \\
-5.14 * * *\end{array}$ & $\begin{array}{c}-0.393 \\
-4.79 * * *\end{array}$ \\
\hline $\begin{array}{l}\text { Adjusted } \\
R \text {-squared }\end{array}$ & 0.730 & 0.725 & 0.750 & 0.728 & 0.782 & 0.795 & 0.804 \\
\hline $\begin{array}{l}\text { Panel B: } \\
\text { Accounting } \\
\text { Fraud }(n=92)\end{array}$ & $\begin{array}{c}{[0 ; 6} \\
\text { months] }\end{array}$ & {$[0 ; 12]$} & {$[0 ; 18]$} & {$[0 ; 24]$} & {$[0 ; 30]$} & {$[0 ; 36]$} & {$[0 ; 48]$} \\
\hline \multicolumn{8}{|l|}{ Parameters } \\
\hline Alpha & $\begin{array}{l}-0.023 \\
-2.88 * *\end{array}$ & $\begin{array}{l}-0.013 \\
-2.06^{*}\end{array}$ & $\begin{array}{l}-0.013 \\
-2.29 *\end{array}$ & $\begin{array}{l}-0.010 \\
-2.18^{*}\end{array}$ & $\begin{array}{l}-0.008 \\
-1.88^{*}\end{array}$ & $\begin{array}{l}-0.002 \\
-0.470\end{array}$ & $\begin{array}{l}-0.003 \\
-1.050\end{array}$ \\
\hline Beta & $\begin{array}{c}1.761 \\
8.34 * * *\end{array}$ & $\begin{array}{c}1.644 \\
10.44 * * *\end{array}$ & $\begin{array}{c}1.641 \\
11.78 * * *\end{array}$ & $\begin{array}{c}1.508 \\
11.70 * * *\end{array}$ & $\begin{array}{c}1.303 \\
12.43 * * *\end{array}$ & $\begin{array}{c}1.141 \\
9.04 * * *\end{array}$ & $\begin{array}{c}1.193 \\
10.50 * * *\end{array}$ \\
\hline$S M B$ & $\begin{array}{c}0.639 \\
2.89 * *\end{array}$ & $\begin{array}{c}0.607 \\
3.92 * * *\end{array}$ & $\begin{array}{c}0.604 \\
4.57 * * *\end{array}$ & $\begin{array}{c}0.621 \\
4.98 * * *\end{array}$ & $\begin{array}{c}0.642 \\
5.63 * * *\end{array}$ & $\begin{array}{c}0.664 \\
6.23 * * *\end{array}$ & $\begin{array}{c}0.616 \\
7.70 * * *\end{array}$ \\
\hline$H M L$ & $\begin{array}{l}0.310 \\
0.920\end{array}$ & $\begin{array}{c}0.615 \\
2.97 * *\end{array}$ & $\begin{array}{c}0.772 \\
4.06^{* * *}\end{array}$ & $\begin{array}{c}0.714 \\
4.48^{* * *}\end{array}$ & $\begin{array}{c}0.517 \\
3.61 * * *\end{array}$ & $\begin{array}{c}0.545 \\
3.84 * * *\end{array}$ & $\begin{array}{c}0.532 \\
3.82 * * *\end{array}$ \\
\hline$U M D$ & $\begin{array}{c}-0.712 \\
-4.08 * * *\end{array}$ & $\begin{array}{c}-0.719 \\
-4.79 * * *\end{array}$ & $\begin{array}{c}-0.591 \\
-4.07 * * *\end{array}$ & $\begin{array}{c}-0.527 \\
-5.30 * * *\end{array}$ & $\begin{array}{c}-0.436 \\
-5.04 * * *\end{array}$ & $\begin{array}{c}-0.402 \\
-4.36 * * *\end{array}$ & $\begin{array}{c}-0.396 \\
-6.80 * * *\end{array}$ \\
\hline $\begin{array}{l}\text { Adjusted } \\
R \text {-squared }\end{array}$ & 0.555 & 0.683 & 0.678 & 0.653 & 0.703 & 0.640 & 0.770 \\
\hline $\begin{array}{l}\text { Panel C: } \\
\text { Illegal } \\
\text { Business } \\
\text { Practices }(n=218)\end{array}$ & $\begin{array}{c}{[0 ; 6} \\
\text { months] }\end{array}$ & {$[0 ; 12]$} & {$[0 ; 18]$} & {$[0 ; 24]$} & {$[0 ; 30]$} & {$[0 ; 36]$} & {$[0 ; 48]$} \\
\hline \multicolumn{8}{|l|}{ Parameters } \\
\hline Alpha & -0.015 & -0.007 & -0.007 & 0.001 & 0.001 & 0.002 & 0.002 \\
\hline
\end{tabular}


Table 2.5 continued

\begin{tabular}{|c|c|c|c|c|c|c|c|}
\hline & $-2.33 * *$ & -1.240 & $-1.45 \$$ & 0.270 & 0.250 & 0.580 & 0.590 \\
\hline \multirow[t]{2}{*}{ Beta } & 1.372 & 1.333 & 1.274 & 1.176 & 1.184 & 1.167 & 1.186 \\
\hline & $7.39 * * *$ & $8.18 * * *$ & $11.03 * * *$ & $6.82 * * *$ & $13.23 * * *$ & $12.69 * * *$ & $14.47 * * *$ \\
\hline \multirow[t]{2}{*}{$S M B$} & 0.616 & 0.756 & 0.681 & 0.498 & 0.673 & 0.681 & 0.691 \\
\hline & $2.79 * *$ & $4.10 * * *$ & $4.57 * * *$ & $2.63 * *$ & $5.13 * * *$ & $5.58 * * *$ & $5.74 * * *$ \\
\hline \multirow[t]{2}{*}{$H M L$} & 0.633 & 0.606 & 0.578 & 0.183 & 0.310 & 0.290 & 0.246 \\
\hline & $2.12 *$ & $2.50 * *$ & $3.38 * * *$ & 0.690 & $2.17^{*}$ & $2.17 *$ & $1.86^{*}$ \\
\hline \multirow[t]{2}{*}{$U M D$} & -0.482 & -0.528 & -0.482 & -0.444 & -0.447 & -0.456 & -0.447 \\
\hline & $-4.17 * * *$ & $-4.87 * * *$ & $-5.18 * * *$ & $-4.78 * * *$ & $-5.10 * * *$ & $-5.02 * * *$ & $-4.55 * * *$ \\
\hline $\begin{array}{l}\text { Adjusted } \\
R \text {-squared }\end{array}$ & 0.464 & 0.562 & 0.621 & 0.616 & 0.722 & 0.736 & 0.760 \\
\hline $\begin{array}{l}\text { Panel D: } \\
\text { Insider } \\
\text { Trading }(n=128)\end{array}$ & $\begin{array}{c}{[0 ; 6} \\
\text { months] }\end{array}$ & {$[0 ; 12]$} & {$[0 ; 18]$} & {$[0 ; 24]$} & {$[0 ; 30]$} & {$[0 ; 36]$} & {$[0 ; 48]$} \\
\hline \multicolumn{8}{|l|}{ Parameters } \\
\hline \multirow[t]{2}{*}{ Alpha } & -0.009 & 0.011 & 0.006 & 0.012 & 0.009 & 0.010 & 0.009 \\
\hline & -1.050 & $1.33 \$$ & 0.940 & $2.15^{*}$ & $1.94 *$ & $2.10^{*}$ & $1.93 *$ \\
\hline \multirow[t]{2}{*}{ Beta } & 1.488 & 1.065 & 1.115 & 0.850 & 0.939 & 0.997 & 1.033 \\
\hline & $6.57 * * *$ & $5.54 * * *$ & $7.95 * * *$ & $5.59 * * *$ & $7.51 * * *$ & $8.85 * * *$ & $10.53 * * *$ \\
\hline \multirow[t]{2}{*}{$S M B$} & 1.007 & 0.628 & 0.549 & 0.468 & 0.535 & 0.539 & 0.596 \\
\hline & $3.93 * * *$ & $2.74 * *$ & $3.32 * * *$ & $2.88 * *$ & $4.19 * * *$ & $4.39 * * *$ & $5.06 * * *$ \\
\hline \multirow[t]{2}{*}{$H M L$} & 0.821 & -0.127 & 0.015 & -0.359 & -0.192 & -0.129 & -0.071 \\
\hline & $1.99 *$ & -0.340 & 0.060 & $-1.36 \$$ & -0.970 & -0.700 & -0.420 \\
\hline \multirow[t]{2}{*}{$U M D$} & -0.754 & -0.798 & -0.649 & -0.607 & -0.561 & -0.535 & -0.466 \\
\hline & $-3.26 * * *$ & $-3.04 * *$ & $-3.82 * * *$ & $-4.38 * * *$ & $-5.12 * * *$ & $-4.77 * * *$ & $-4.71 * * *$ \\
\hline$R$-squared & 0.453 & 0.460 & 0.525 & 0.546 & 0.598 & 0.611 & 0.621 \\
\hline $\begin{array}{l}\text { Panel E: } \\
\text { Governance } \\
\text { Problems }(n=107)\end{array}$ & $\begin{array}{c}{[0 ; 6} \\
\text { months] }\end{array}$ & {$[0 ; 12]$} & {$[0 ; 18]$} & {$[0 ; 24]$} & {$[0 ; 30]$} & {$[0 ; 36]$} & {$[0 ; 48]$} \\
\hline \multicolumn{8}{|l|}{ Parameters } \\
\hline \multirow[t]{2}{*}{ Alpha } & -0.042 & -0.022 & -0.011 & -0.003 & -0.002 & -0.003 & -0.004 \\
\hline & $-3.04 * *$ & $-2.40 * *$ & $-1.90^{*}$ & -0.470 & -0.280 & -0.510 & -0.810 \\
\hline \multirow[t]{2}{*}{ Beta } & 1.661 & 1.533 & 1.326 & 1.161 & 1.192 & 1.185 & 1.269 \\
\hline & $4.85 * * *$ & $6.79 * * *$ & $8.95 * * *$ & $6.33 * * *$ & $9.37 * * *$ & $9.30 * * *$ & $13.34 * * *$ \\
\hline \multirow[t]{2}{*}{$S M B$} & 0.679 & 0.706 & 0.737 & 0.487 & 0.635 & 0.623 & 0.585 \\
\hline & $1.53 \$$ & $2.91 * *$ & $3.75 * * *$ & $2.23 *$ & $3.50 * * *$ & $4.16^{* * *}$ & $4.21 * * *$ \\
\hline \multirow[t]{2}{*}{$H M L$} & 0.530 & 0.757 & 0.733 & 0.430 & 0.504 & 0.556 & 0.575 \\
\hline & 1.060 & $2.39 * *$ & $2.95 * *$ & $1.35 \$$ & $2.30 *$ & $2.65^{* *}$ & $3.13^{* *}$ \\
\hline \multirow[t]{2}{*}{$U M D$} & -0.264 & -0.131 & -0.351 & -0.235 & -0.321 & -0.269 & -0.327 \\
\hline & -0.920 & -0.570 & $-2.82 * *$ & $-2.00^{*}$ & $-3.22 * * *$ & $-3.21 * * *$ & $-4.41 * * *$ \\
\hline $\begin{array}{l}\text { Adjusted } \\
\text { R-squared }\end{array}$ & 0.243 & 0.371 & 0.453 & 0.388 & 0.517 & 0.525 & 0.592 \\
\hline
\end{tabular}

In Panels B-E of Table 2.5, we break down our sample into four allegations: accounting fraud, illegal business practices, insider trading, and governance problems. In the case of accounting fraud allegations, firms' negative abnormal returns persist significantly for up to 30 months (and stays negative afterwards, though not significant any more). We do not observe this result for firms in Panels C and D. On the contrary, alpha reverses as long as the stocks are held longer than 24 
months for firms facing charges of illegal business practices. Though not statistically significant, the monthly risk-adjusted alpha of a strategy investing in firms sued for illegal business practices is mildly positive. For firms and directors charged with insider trading, abnormal returns look even more prosperous. Initially (a zero to six months holding period), the monthly alpha is negative but not significant. Shortly afterwards, the strategy starts generating positive and significant monthly alphas in excess of up to $1.2 \%$. A further striking feature is this group's exposure to HML. Over short holding periods, the coefficient is still positive (being exposed to value stocks) and it switches signs after 18 months (being exposed to growth stocks with low book-to-market ratio). For comparison, allegations on governance problems are also more likely to have a systematically negative effect on performance. Here, alpha over a maximum period of one year is significantly negative. We conclude that for these groups of firms the filing of a class-action lawsuit has a disciplining effect in terms of stock market performance. This conclusion lends strong support to our Hypothesis 1.

\subsubsection{The Role of Triggering Events before the Filing Date}

Does it make a difference if an event prior to the actual filing of the lawsuit triggers shareholder litigation? In other words, if the investing public is already aware that the firm is in a "problematic" situation before the filing of the lawsuit, then does the filing of the lawsuit still make a difference for these types of firms? And if yes, then what returns can be expected on these types of firms? We therefore investigate whether any disciplining effect stems from the actual litigation or if shareholders already were monitoring these firms beforehand. Recall from Section 2 that we were not able to spot differences in short-term pre-event performance prior to the lawsuit between the aforementioned two groups. In order to investigate this "true filing effect", we split our sample into those firms, which have experienced these triggering events prior to the filing versus those firms where the shareholder litigation database and the respective court documents do not document such an event. 


\section{Table 2.6: Long Term Performance in Calendar Time - Triggering Events}

We conduct the same calendar time portfolio regression as in Table 2.5 but distinguish between classactions that were preceded by "triggering events" (Panel A) or not (Panel B). Below we test for the significance of the differences in the estimated average alpha coefficients in the portfolio depending on their holding period.

\begin{tabular}{|c|c|c|c|c|c|c|c|c|c|}
\hline $\begin{array}{l}\text { Panel A: } \\
\text { Triggering Event } \\
(\mathrm{n}=359)\end{array}$ & $\begin{array}{c}{[0 ; 6} \\
\text { months] }\end{array}$ & {$[0 ; 12]$} & {$[0 ; 18$} & & {$[0$} & 24] & {$[0 ; 30]$} & {$[0 ; 36]$} & {$[0 ; 48]$} \\
\hline Parameters & & & & & & & & & \\
\hline Alpha & -0.019 & -0.007 & -0.00 & & 0.0 & & -0.002 & -0.002 & -0.002 \\
\hline & $-2.88 * *$ & $-1.35 \$$ & -1.73 & & -0.0 & 50 & -0.390 & -0.550 & -0.500 \\
\hline Beta & 1.294 & 1.180 & 1.098 & & 0.9 & & 0.983 & 1.035 & 1.031 \\
\hline & $7.54 * * *$ & $9.00 * * *$ & $10.37 *$ & & 7.06 & $* * * *$ & $10.15 * * *$ & $11.64 * * *$ & $11.69 * * *$ \\
\hline$S M B$ & 0.650 & 0.720 & 0.69 & & 0.6 & & 0.694 & 0.734 & 0.759 \\
\hline & $3.68 * * *$ & $4.94 * * *$ & $5.59 *$ & & 4.44 & $* * *$ & $5.75 * * *$ & $6.59 * * *$ & $7.17 * * *$ \\
\hline$H M L$ & 0.164 & 0.208 & 0.23 & & -0.1 & 02 & 0.057 & 0.125 & 0.110 \\
\hline & 0.650 & 0.940 & 1.38 & & -0.4 & 180 & 0.390 & 0.970 & 0.840 \\
\hline$U M D$ & -0.425 & -0.493 & -0.48 & & -0.4 & 63 & -0.448 & -0.446 & -0.416 \\
\hline & $-3.81 * * *$ & $-4.23 * * *$ & $-5.76^{*}$ & & -4.41 & $* * *$ & $-4.65 * * *$ & $-4.55 * * *$ & $-4.21 * * *$ \\
\hline $\begin{array}{l}\text { Adjusted } \\
R \text {-squared }\end{array}$ & 0.447 & 0.530 & 0.56 & & 0.5 & & 0.597 & 0.620 & 0.623 \\
\hline $\begin{array}{l}\text { Panel B: } \\
\text { No Triggering } \\
\text { Event }(\mathrm{n}=290) \\
\end{array}$ & {$[0 ; 6$ months $]$} & {$[0 ; 12]$} & {$[0 ; 18$} & & {$[0 ;$} & $24]$ & {$[0 ; 30]$} & {$[0 ; 36]$} & {$[0 ; 48]$} \\
\hline Parameters & & & & & & & & & \\
\hline Alpha & -0.012 & -0.002 & -0.00 & & -0.0 & & -0.002 & -0.001 & -0.001 \\
\hline & $-2.07 *$ & -0.360 & -1.04 & & -0.5 & & -0.630 & -0.200 & -0.290 \\
\hline Beta & 1.305 & 1.197 & 1.27 & & 1.1 & & 1.141 & 1.109 & 1.148 \\
\hline & $8.21 * * *$ & $11.88 * * *$ & $13.28 *$ & & 12.27 & $7 * * *$ & $12.30 * * *$ & $12.20 * * *$ & $15.63 * * *$ \\
\hline$S M B$ & 0.600 & 0.435 & 0.46 & & 0.4 & & 0.472 & 0.482 & 0.497 \\
\hline & $3.50 * * *$ & $3.64 * * *$ & $4.69 *$ & & 4.28 & $* * *$ & $5.99 * * *$ & $6.31 * * *$ & $6.63 * * *$ \\
\hline$H M L$ & 0.447 & 0.361 & 0.49 & & 0.3 & & 0.267 & 0.247 & 0.267 \\
\hline & $1.93^{*}$ & $2.25 *$ & $3.99 *$ & & 2.90 & ** & $2.25^{*}$ & $2.12 *$ & $2.51 * *$ \\
\hline$U M D$ & -0.744 & -0.587 & -0.47 & & -0.4 & 27 & -0.415 & -0.391 & -0.397 \\
\hline & $-4.86 * * *$ & $-7.14 * * *$ & $-5.37 *$ & & -5.95 & $* * *$ & $-6.02 * * *$ & $-5.45 * * *$ & $-5.05 * * *$ \\
\hline $\begin{array}{l}\text { Adjusted } \\
R \text {-squared }\end{array}$ & 0.615 & 0.671 & 0.68 & & 0.7 & & 0.743 & 0.746 & 0.774 \\
\hline $\begin{array}{l}\text { Test for } \\
\text { differences } \\
\text { in Alphas }\end{array}$ & {$[0 ; 6 r$} & nonths] & {$[0 ; 12]$} & {$[0$} & $18]$ & {$[0 ; 24]$} & {$[0 ; 30]$} & {$[0 ; 36]$} & {$[0 ; 48]$} \\
\hline $\begin{array}{l}\text { Difference Trigge } \\
\text { Event vs. No Trig }\end{array}$ & & 007 & -0.005 & & 004 & 0.002 & 0.000 & -0.001 & -0.001 \\
\hline t-stat & & 502 & -0.255 & & 078 & 0.479 & 0.000 & -0.150 & -0.166 \\
\hline
\end{tabular}


We continue to rely on the calendar time portfolio approach and also check for difference in average portfolio alphas by using the following formula:

$$
\frac{\bar{\alpha}_{p 1}-\bar{\alpha}_{p 2}}{\sqrt{\frac{\sigma_{p 1}^{2}}{\sqrt{n_{p 1}}}+\frac{\sigma_{p 2}^{2}}{\sqrt{n_{p 2}}}}}
$$

where $\mathrm{p}_{1}$ and $\mathrm{p}_{2}$ resemble the average alphas of the individual portfolios (triggering event yes or no). The $n_{1}$ and $n_{2}$ are the respective sample sizes of the two portfolios. Note that these are two mutually exclusive sample groups that only share the common feature of being sued by their shareholders. The results are in Table 2.6 below.

Although initial short- and medium-term holding period alphas are more negative for firms with triggering events before the lawsuit, there is not a statistically significant difference in their alphas from firms without a triggering event in the past. Hence, we fail to reject the hypothesis of similar long-term returns for firms whose self-disclosure of accounting problems or SEC investigations have triggered the filing rather than shareholders' dissidence. According to the analysis, it is not fundamental events before the filing that make investors lose faith in the company and directors. Even though both groups of firms start off at different levels after 40 trading days, this difference does not manifest itself in differences in expected long-term returns between the groups. It seems to be the official filing of a lawsuit by shareholders themselves that erodes confidence. With this finding, we fail to reject Hypothesis 2 and conclude a "true filing effect".

\subsubsection{The Role of Other Stakeholder Groups as External Financiers}

Closely related to the aforementioned economic effects and to employees as stakeholders there is an open question with respect to another important group of external financiers: corporate creditors. The question of how shareholders fare in the long-term in a class-action lawsuit also leads to the debate of the consequences for the sued entity's cost of debt. Are both shareholders and creditors equally hurt or compensated in class-action lawsuits or is either of the groups compensating for the gains or losses of its financing counterpart? The value of outstanding bonds is among others predominantly influenced by the corporation's value in bankruptcy state. Therefore, which types of allegations and class-action lawsuits are likely to put the firm closer to this state, and how this state relates to shareholder returns is an unresolved issue.

Both issuer and issue credit ratings, as well as bond returns and yield spreads, are likely to capture only the effects on holders of traded debt securities. Not every corporation in our sample is expected to actually have publicly traded 
debt. In fact, we are only able to obtain long-term issuer credit ratings from Standard $\&$ Poors (COMPUSTAT item \#280) for 62\% of our sample. Of those 402 observations, 193 got downgraded but almost the same amount of firms (185) got upgraded or remained unchanged in their credit rating. The remaining number of firms must have either defaulted on or retired existing debt since information one year after the lawsuit filing is unavailable. Incompleteness of data is why we focus on a broader measure of financial health and solvency based on the expected probability of default. Bharath and Shumway (2008) have derived a "naïve" version of the KMV-Merton model that is parsimonious in its computation and shows more than a fair predictive power compared to hazard models and the actual KMV model of expected distance to default. ${ }^{5}$ The correlation with the original distance-to-default ranges at 0.88 and significantly predicts actual defaults on debt and bankruptcy. This model requires fairly parsimonious ingredients for its computation. We estimate the volatility of firm value $\sigma_{V}$ (naïve $\sigma_{V}$ ) with the following formula:

$$
\sigma_{V}=\frac{E}{E+F} \sigma_{E}+\frac{F}{E+F}\left(0.05+0.25 * \sigma_{E}\right) .
$$

In line with Bharath and Shumway's approach, we use the annualized standard deviation of daily stock returns as $\sigma_{E}$ and use market capitalization (number of shares outstanding times share price) as $E$. The $F$, the face value of debt, is debt in current liabilities (COMPUSTAT item \#34) plus one-half of long term debt (COMPUSTAT item \#9). The resulting volatility of firm value is our addition to the naïve distance to default (naïve $D D$ ) measure, which is computed the following way:

$$
\frac{\ln [(E+F) / F]+\left(r_{i t-1}-0.5 \text { naive } \sigma_{V}^{2}\right) T}{\text { naive } \sigma_{V} \sqrt{T}},
$$

where the associated probability of default equals:

$$
\pi_{\text {naive }}=N(- \text { naïve } D D) \text {. }
$$

Here, $N(\cdot)$ equals the cumulative standard normal distribution function. In order to capture the effect of a shareholder initiated class-action lawsuit filing on a possible increase of the expected probability of default (under which creditors as financial claimholders suffer), we split our sample into two distinct time periods. Our prelawsuit period spans from 270 trading days until 21 days before the filing. This is motivated by the fact that we want to reasonably isolate increases in volatility in stock prices from rumors or possibly triggering events.

\footnotetext{
${ }^{5}$ Note that the actual KMV-Merton model involves a far more complex iterative estimation procedure compared to the simplified version of Bharath and Shumway (2008).
} 


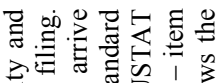

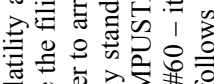

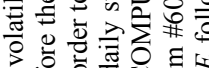

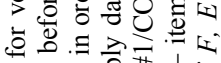

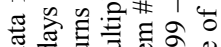

on

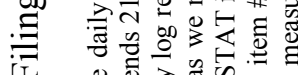

至

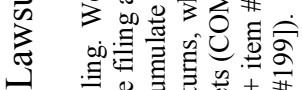

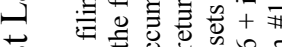

总

7

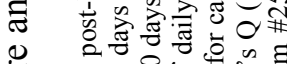

은

屯

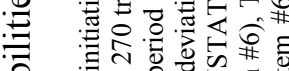

居

은

날

表

क

施

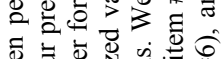

5

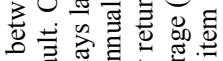

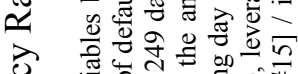

若

它

क

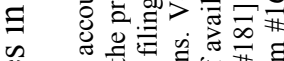

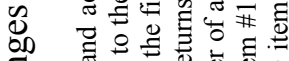

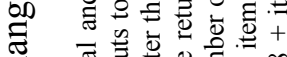

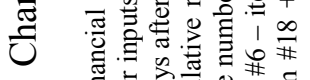

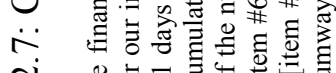

نู

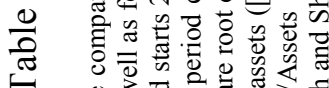

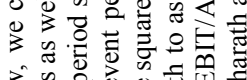

政

告

要

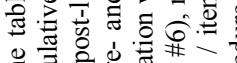

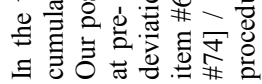

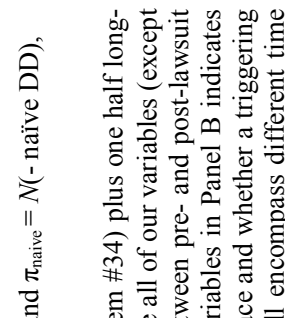

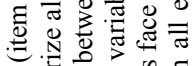

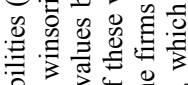

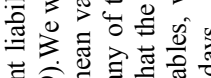

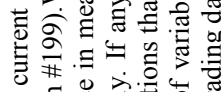

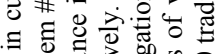

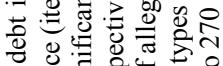

늘. 50 क्ष

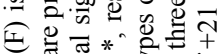

专.

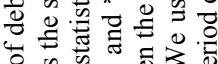

y क क ए

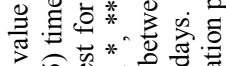

荛

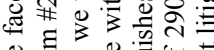

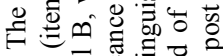

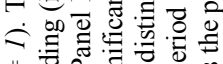

II

․

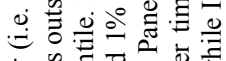

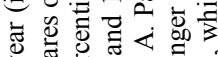

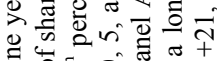

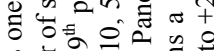

능

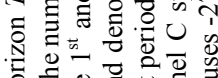

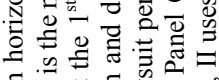

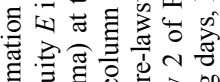

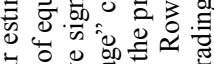

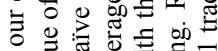

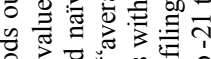

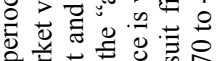

记

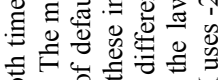

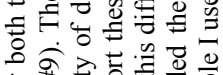

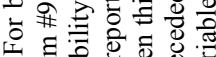

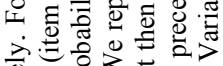

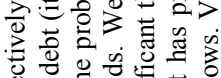

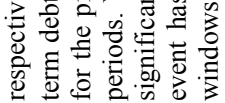

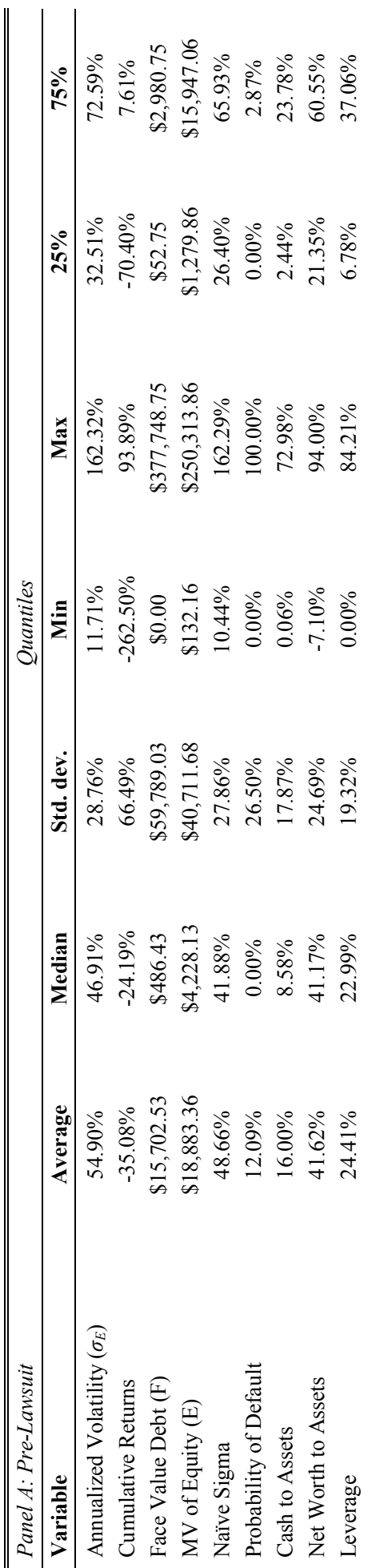




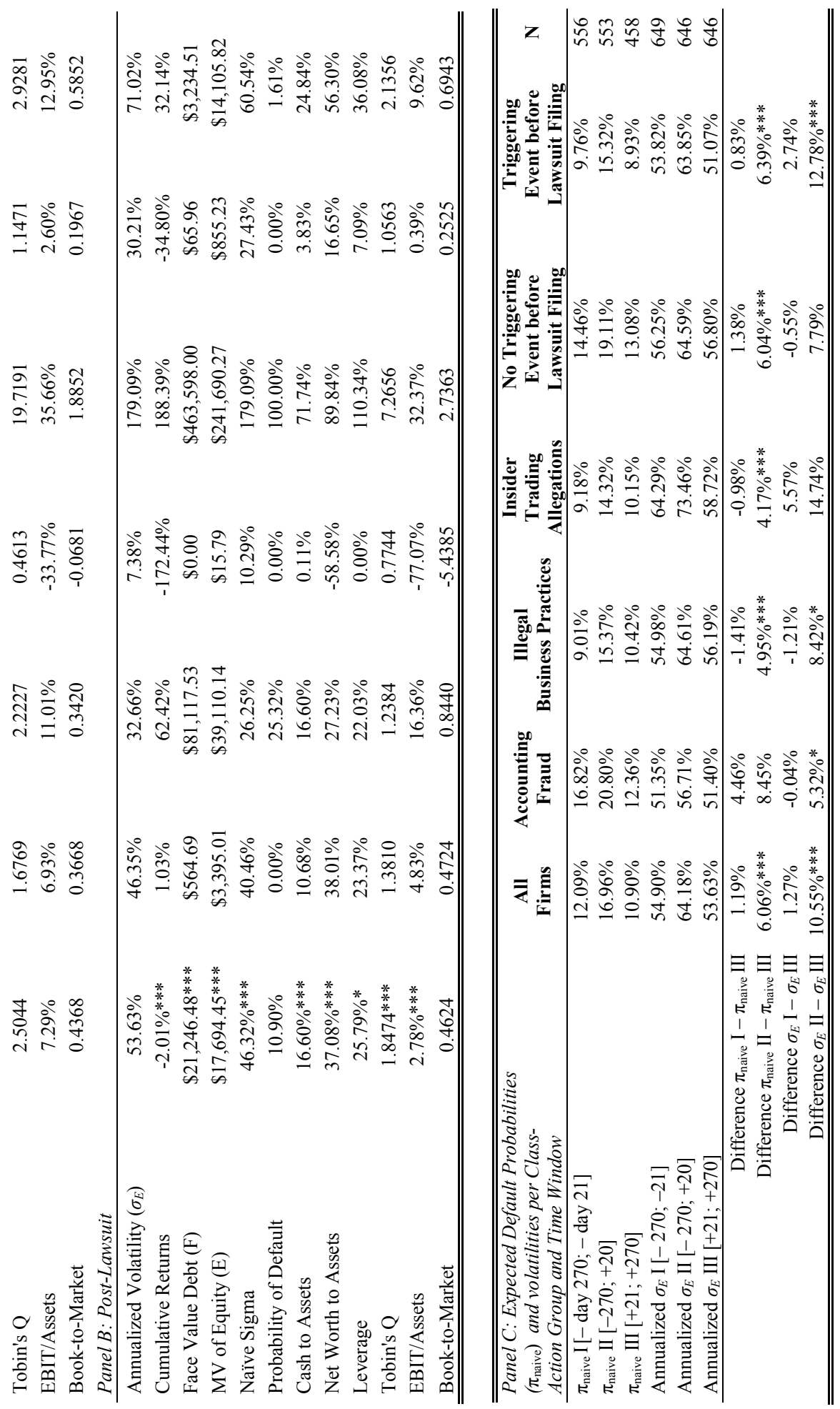


Our post lawsuit estimation period starts at 21 trading days and goes up to 270 after the lawsuit. Here we would like to isolate repercussions from the lawsuit filing, possibly even from the media. For robustness we also include the lawsuit period up to 20 days after the filing. We use daily data in order to compute volatilities and cumulative returns prior and after the lawsuit event. Further, we require balance sheet information of the firms for the amounts of outstanding debt and equity. Data on financial stability and default probabilities is further supplemented with ratios of cash to assets, net worth to assets, leverage, Tobin's Q, EBIT to Assets, and book-to-market. Since the estimation procedure requires full availability of stock price and company characteristics, our sample size reduces from 650 to 556. The statistics portraying financial variables before and after the lawsuit filing can be found in Table 2.7 below.

Several key figures from the table are worth addressing. Most importantly the probability of default of $12.09 \%$ before the lawsuit filing is already considerably higher than the unconditional 8.95\% as reported in Bharath and Shumway (2008). Their sample pertains to an average of monthly data for all U.S. firms between 1980 and 2003 for which there is complete data. This key finding lends credibility to why we call these firms "distressed". Moreover, the probability of default does not increase after the lawsuit filing. This finding means that any potential recovery and/or long-term disciplining effect does not come at the expense of creditor groups in the form of a higher default probability. We therefore conclude a disciplining effect, which in our setting rejects Hypothesis 3.

In order to further add to the notion of "distress", we also check for transformations in other important variables, which are among others input variables for the computation of the expected default probability. We complement these by Tobin's Q, book-to-market, net worth to assets, and cash to net assets. The former two variables are standard measures of the market value of a firm's assets relative to its replacement value and book value of equity relative to its market value, respectively. The last two variables can be referred to as measures of borrower quality (Massoud, Nandy, Saunders, and Song, 2009). In order to examine how the firm's operation might be affected by the lawsuit, we also look at EBIT relative to assets. It is therefore intriguing to examine how these variables change from the preto the post-lawsuit period. We note a significant decrease in Tobin's Q combined with an increase in the firms' book-to-market ratios in the year after the lawsuit. This lower market valuation might hint at the fact that these firms are "shunned" by investors. We further observe a sharp decrease in profitability (as measured by EBIT/Assets) and net worth. This non-negligible reduction lends further credibility to the notion that our sample of firms that are facing litigation is significantly distressed. Cash and leverage ratios do not point at any evidence of serious restructuring activities subsequent to the litigation. Note that the sample size of firms 
with complete information has decreased by 98 firms from 556 to 458 . Our results might be an artifact of a potential selection bias in the number of firms in the sample since we are comparing them only to firms that have complete post-litigation data. Still, if we investigate the expected default probability before the lawsuit initiation of only those companies that lack sufficient post-lawsuit data, then their expected default probability is statistically indistinguishable from our original sample of all sued firms (12.09\% vs. 12.34\%). However, if we expand the estimation period for naïve $D D$ and include the 41 trading days prior and subsequent to the lawsuit filing the expected probability of default jumps from 12.09 to $16.96 \%$. This value is more than twice as high as the value for the COMPUSTAT universe between 1980 and 2003 and resembles a significant risk to the financial health of the firm.

In Panel $\mathrm{C}$, we also distinguish between class-action groups and time periods. Here, we only focus on $\pi_{\text {naive }}$ and the annualized volatility of equity $\left(\sigma_{E}\right)$ since these variables change on a daily basis. By this classification we observe that results are fairly sensitive to the extension of the sample period by 41 trading days until the start of the post-lawsuit period. We further note that in the post-lawsuit filing period, the measure of $\pi_{\text {naive }}$ is invariant in comparison to the distinction of allegation types. If the company is facing allegations for the violation of duty of loyalty (i.e. insider trading allegations), then we observe the lowest expected default probability both prior and after the lawsuit filing compared to violations of duty of care. The former group also bears the highest pre-lawsuit annualized volatility, which is in line with managers increasing firm risk. Since their compensation is likely to include option packages, an increase in volatility (the options' Vega) is in managers' best interest. Only for this allegation do we observe the strongest decline in $\sigma_{E}$. When we contrast firms with and without triggering events, we conclude that the naïve KMV-Merton model seems to have some predictive power for the occurrence of financial distress. Firms without a triggering event have an almost $50 \%$ higher probability of default over firms where a triggering event has taken place. With respect to the sharp decrease of $\pi_{\text {naive }}$ in firms facing accounting fraud, a possible explanation might be closer monitoring and more conservative management subsequent to litigation.

\subsection{Possible Explanations and Practical Implications}

How can we reconcile our results with shareholders' motivations to sue companies and possible long-term disciplining effects? According to Coffee (2005), class-action lawsuits occur more often in the U.S. due to the differences in ownership structure and shareholder base. Consequently, minority shareholders and the managerial labor market are the ultimate disciplinary mechanism for corporate control. The latter is not the central topic of this paper and shareholder proxy contests occur very rarely and with limited success (Mulherin and Poulsen, 1998). 
According to Peng and Röell (2008a), litigation is the central punishment device available for shareholders, and distinguishes the U.S. capital market from other markets. The question then becomes: who benefits from this punishment and what are its effects? Are there any long term merits in terms of disciplining and learning for the shareholder and the firm or do claims only center around the settlement amount and potential damages? Who gains and who suffers if shareholder litigation puts firms into potential distress? With respect to illegal insider trading claims, our analysis provides clear evidence of a disciplining effect. If selected individuals rather than the whole firm are sued, then over the long-term the effect lessens and even reverses into positive abnormal returns. A potential explanation might be that the firm is closer to financial distress in the form of possible default. Although we find decreases in market valuation and operating performance, our analysis in Subsection 3.5 rejects this explanation. We find that the probability of default actually decreases after the filing of a lawsuit. This observation actually benefits both groups of financial claimholders and a wealth transfer is absent.

Concerning insider trading due to stock price manipulation, several issues are worth addressing. We acknowledge that the communication of company information to investors is essential to signal a healthy condition to the market. When this communication is taken to deceptive extremes, managers violate their duty of loyalty. The possibility for this process to hold requires the assumption that stock prices do not fully reflect leeway for manipulation (Peng and Röell, 2008b). However, investors tend to be uncertain about the manager's true ability to move the stock price effectively. This uncertainty does not hold if accounting fraud as a firmwide systematic malpractice is alleged. Illegal business practices and accounting fraud are de facto systematically adverse events that affect the entire corporation, which seems to erode investor confidence on a more permanent basis. With respect to the latter, the naïve probability of default is highest, which indicates a more adverse systematic effect on the corporate entity. Though not the central topic of this paper, it might be interesting to investigate long-term performance differentials between firms being sued for insider trading before and after Sarbanes-Oxley (SOX). Since SOX penalizes managerial insider trading to a higher extent, investors might interpret the violation of duty of loyalty to be particularly grave if heightened personal liability have not prevented managers from self-dealing.

In this paper, we have viewed the pre- and post-lawsuit filing periods as times of "distress", which have triggered shareholders' dissidence. The question whether corporations that face shareholder litigation are truly under distress is worth addressing. Conventionally, the academic literature distinguishes financial from 
economic distress. ${ }^{1}$ Our paper focuses on self-inflicted financial distress, which does not pertain to an increase in liabilities that erodes solvency levels. Our measure of expected probability of default in shareholder litigation cases is more likely to be determined by (our approximation of) the volatility of asset value and its past cumulative returns rather than an increase in leverage beyond debt capacity. An observation, which is in line with the observation of prior literature on financial distress, is the sharp decrease in operating performance subsequent to litigation (cf. Table 2.7). This decrease hints at serious indirect costs of litigation for the firm, which are close to the values of Andrade and Kaplan (1998). The discussion about costs also brings U.S. back to the initially raised question of management-borne costs of shareholder litigation. Since in our case of shareholder litigation, top management is truly responsible for the inception of financial distress, an efficient managerial labor market should replace the incumbents. Ultimately the question whether financial distress is a self-inflicted product of individuals (as in our cases of litigation), or a result of systematic economic shocks, or industry factors determines the future viability of the enterprise. Our long-term performance differential between firms being sued for insider trading versus firms sued for firm-wide malpractices can be explained in the following way. Insider trading can be more easily pinned down to individuals, whereas accounting fraud and/or illegal business practices is more likely to be a product of many. In the case of insider trading, the observed action of the lawsuit or reputational costs discipline existing managers, or a more efficient and ethical management replaces the incumbent managers. In the latter case, new managers are aware of the prior lawsuit, which their predecessors faced, and this information set deters them from any self-dealing actions.

We further document shareholder wealth effects for firms that face accounting fraud allegations. In a recent study, Kedia and Philippon (2009) demonstrate that subsequent to the disclosure of fraud (implicitly the filing of the lawsuit in our case, and eventually the final verdict) firms typically shed labor and capital to become more productive. This results from the high growth period (also shown by our strongly negative HML loading in Table 2.2) in which wrong accounting data encompasses high levels of investment and the hiring of additional employees. In general, by comparing Tables 2.4 and 2.6, we encounter the same pattern as predicted by Kedia and Philippon's model. Firms in our sample experience a transformation from a negative to a positive SMB coefficient. Besides, most of our sample firms (exception illegal insider trading) develop into fallen angels. The HML coefficient turns from strongly negative into a positive coefficient. Still, at least in our analysis, the true long-term economic effects of accounting fraud and higher productivity do not materialize into higher expected returns.

\footnotetext{
${ }^{1}$ See Senbet and Seward (1995) for a survey of the literature. Almeida and Philippon (2007) have derived a model of (risk-adjusted) costs of financial distress
} 
In case the corporation has already been facing problems before the filing date in terms of self-disclosure or legal investigation by third parties, it suffers additionally from the filing of the lawsuit by its shareholders. This is documented by the lack of significantly different alphas between this group and a group without a pre-filing triggering event and the fairly isomorphic patterns before the actual lawsuit filing. Even though these two groups can be fundamentally different, they still share the common feature that both groups are being sued by their shareholders. Therefore, we conclude that the lawsuit per se and not any pre-filing events drives the long-term post event performance.

We suggest several main directions for further research. What seems important is to further evaluate the performance until the filing of the lawsuit. As we have seen in Figure 2.1, the market is substantially contaminated with rumors, which result in a stock price drop before the filing, and then gets further aggravated by the eventual filing. Still, we also observe a similar pattern for event firms in which a triggering event is absent. Alternative analyses could also shift the investment date of the calendar time portfolios further in time. However, this shift has the drawback of not reflecting the investor's perception at the time the investor decides to file the lawsuit and to possibly bear additional costs (unless the entire stake is sold). An open question remains on the role of the out-of-court settlements or, alternatively, the final verdict or dismissal dates. It will be interesting to relate immediate stock price reactions on these dates to the affected firms in our sample. Due to the resolution of uncertainty subsequent to these dates, we interpret this to be generally good news for the market. Nevertheless, we expect differences between allegation types and the potential severity in terms of the upcoming lawsuit. As a final point the relation between the violation of duty of loyalty, management turnover, and disciplining effects remains unexplored. Is long-term performance reversal a product of a replacement of incumbents or is there a serious deterrence effect for the insiders who stay in charge?

Moreover, open questions remain whether initiated lawsuits are costly for the shareholders and whether they are the only punishing device to resort to. By construction our research is U.S.-centered in the sense that class-action lawsuits are a frequently occurring and truly American phenomenon. Although recently regulated by the PSLRA, there is still an ongoing debate on whether the regulation has made the merits matter more or less in these lawsuits. Although, Johnson, Nelson, and Pritchard (2007) state that the merits matter more after the introduction of PSLRA, Choi (2007) concludes the opposite. Our sample starts after the introduction of the PSLRA so that we do not have the opportunity to distinguish between periods. In our research, we deliberately ignored whether the initiation of a lawsuit of ex post has been meritorious or not. 
We also document a few limitations. Event study methodology until so far is unfortunately still only a crude way to measure true security price performance subsequent to corporate events. Especially in volatile pre-event estimation windows, betas are likely to be mis-estimated and expected returns misspecified. A significant fraction of our firms facing class-action lawsuits come from the period between 2001 and 2003. This rather turbulent market environment is likely to produce misstated betas, which only depend on past returns. More sophisticated approaches by, for example, Cosemans, Frehen, Schotman, and Bauer (2009), could sharpen the precision of the beta estimation by weighing between conditioning economic variables and past returns.

Despite the appealing simplicity of using calendar time portfolios in our analysis, the asset pricing literature is so far not unanimous with respect to an accepted model of risk-adjusted performance (Ritter and Welch, 2002). Therefore, it is likely that any research on long-term post-event performance is sensitive to the methods employed. We do not take a stance on which asset pricing model produces the most precise results but motivate our approach from economic experience. The role of liquidity and investor recognition subsequent to materially adverse corporate events might play a role and is subject to further research.

\subsection{Conclusion}

In this paper, we provide the first credible evidence of the costs and gains for shareholders and creditors from litigation against distressed firms subsequent to the violation of duty of care and/or of loyalty. The question of performance subsequent to the filing of a class-action lawsuit ultimately determines whether shareholders hold on to their shares and bet on a recovery of the stock price. The alternative is to sell off the equity stake in the firm and either to take an out-of-court settlement, or wait for a final verdict. Our analysis shows that a recovery of the stock price highly depends on the type of allegation brought forward, the time horizon, and the estimation technique of long-term performance. Whether a stock price recovery kicks in and how potential shareholder losses materialize ultimately has important policy implications for securities market regulators. We do not only address shareholders' role in our analysis but also focus on the firm's expected probability of default in order to capture potential effects on creditors as the other major group of external suppliers of capital. Answering this question has important implications for institutional investors as lead plaintiffs that might have dual positions in stocks and bonds in the firms they take to court. Our analysis shows that investors with dual holdings should not be deterred from resorting to lawsuits.

For allegations involving the corporate entity as a whole, we conclude that the event is highly disruptive. In the short run, the filing of a class-action lawsuit is a 
materially adverse corporate event where long-term economic and financial effects depend on the nature of the allegations. Still, it remains to be seen how the role of class-action lawsuits as a governance mechanisms will evolve in the future and whether shareholders will continue to resort to this disruptive mechanism. 


\section{Appendix: Sample of Original Allegation Types}

Keywords for our coding into seven allegation types are underlined and marked in italics.

Insider Trading Allegations (violation of "duty of loyalty")

Ascend Communications Inc. (CUSIP: 043491). Filing date: 2 December 1997

"[...] The original Complaint charges defendants with violating federal securities and state laws, including Section 10(b) of the Securities Exchange Act of 1934 and Section 11 of the Securities Act of 1933, by engaging in an illegal scheme and deceptive course of conduct designed to inflate Ascend's stock price through positive statements concerning Ascend's business, earnings and its growth prospects, despite the fact that, at the time the statements were made, defendants knew, or recklessly disregarded, but failed to disclose to investors, that sales of Ascend's advanced modem products would all but cease because of, among other things, serious software and firmware problems. The defendants' scheme allowed Ascend's officers and directors to sell their Ascend shares at enormous gains, exceeding $\$ 40$ million in proceeds."

Taken from: http://securities.stanford.edu/1011/ASND97/

Accounting Violations/Illegal Business Practices (violation of "duty of care")

Symantec Corporation (CUSIP: 871503). Filing date: 7 January 1997

"[...] The original complaint alleges that during the Class Period, defendants engaged in a fraudulent scheme and course of business that operated as a fraud or deceit on all persons who purchased or otherwise acquired Symantec stock. As set forth hereafter, these false and misleading statements included statements about (1) Symantec's new Windows 95-related utility software products known as Norton Navigator, Norton AntiVirus and Norton Utilities; (2) Symantec's Enterprise products; (3) Symantec's sales in Europe; and (4) other aspects of Symantec's business. Furthermore, Symantec's financial statements for its first and second quarters of fiscal 1996 (ended June 30 and September 29, 1995) were false and misleading in violation of Generally Accepted Accounting Principles."

Taken from: http://securities.stanford.edu/1013/SYMC97/

Illegal Business Practices/Governance problems (violation of "duty of care”)

Duke Energy Co. (CUSIP: 26441C). Filing date: 23 May 2002.

"[...] The original complaint alleges that Duke failed to disclose that it was engaging in electricity trades involving simultaneous purchases and sales of power at the same price, overstated Duke's revenues in its public SEC filings and elsewhere by including in such revenues sums received in connection with such simultaneous purchases and sales of power, and failed to disclose that Duke did not have in place sufficient management controls to prevent Duke's traders from engaging in simultaneous purchases and sales of power at the same price. The complaint further alleges that Deloitte \& Touche violated the common law by certifying Duke's financial statements and by allowing its unqualified opinion to be incorporated by reference into Duke's filings with the SEC despite the fact that such financial statements and filings were materially misleading in that they materially overstated Duke's revenues by counting as revenue sums received in connection with simultaneous purchases and sales of power at the same price. After the foregoing became known to the public, the complaint alleges, Duke stock tumbled to as low as $\$ 32.89$ on May 21,2002 , down from a class period high of $\$ 47.74$.”

Taken from: http://securities.stanford.edu/1024/DUK02-01/ 


\section{Chapter 3}

\section{Sued or Glued - How To Align The $\mathrm{CEO} ?^{1}$}

We argue that class-action lawsuits are an important disciplining mechanism available to dispersed shareholders. In our view, the ex ante threat of a lawsuit ("sued") limits the potentially dysfunctional behavior of CEOs that is triggered by stock option incentives. Our empirical results show that the likelihood and severity of class-action lawsuits is higher, the greater the component of stock option incentives driven by corporate governance factors. Furthermore, we document that the relation between governance-induced option incentives and the occurrence of class-action lawsuits is less pronounced after the adoption of the Sarbanes-Oxley (SOX) Act in 2002. We conclude that SOX offers an additional external disciplining threat for managers engaging in excessive risk taking that is triggered by governance-induced incentives and entrenched boards. Our findings have important policy implications for shareholders and external monitors with respect to the optimal design of CEO incentive schemes ("glued").

\subsection{Introduction}

In this paper, we examine to what extent dispersed shareholders use classaction lawsuits as a disciplining mechanism. In a system characterized by dispersed ownership, as is the case in the United States, CEO incentives are predominantly provided via equity incentives (Hall and Liebman, 1998; Core, Guay, and Verrecchia, 2003). Although equity incentives help to align the incentives of the CEO with those of the owners of the firm ("glue"), these incentives are not uncontroversial. It has been argued that the non-linear payoff associated with stock options especially has an effect on excessive risk taking and stock market

\footnotetext{
${ }^{1}$ This paper is based on Bauer, Braun, and Moers (2009)
} 
manipulation (for example, Peng and Röell, 2008b). Given that these activities are costly to shareholders, it is important to understand what disciplining mechanisms shareholders have at their disposal to limit these activities. Blockholders like institutional investors can revert to shareholder activism ("voice") or threaten to sell the stock ("exit") to push for governance changes. Although there is debate about whether these mechanisms are at all effective (Gillan and Starks, 2007), they are clearly unavailable to dispersed shareholders. We argue that, with dispersed ownership, class-action lawsuits are an important disciplining mechanism to limit dysfunctional CEO behavior due to stock option incentives. In essence, the threat to sue helps to restore the "glue component" of equity incentives and thus better align incentives.

CEO compensation lies at the heart of the principal-agent conflict in corporate governance. Because CEOs themselves are not the owners of the corporation that they steer, their objectives have to be aligned with shareholders', who are the ultimate owners. In their seminal paper, Jensen and Murphy (1990) argue that CEOs lack enough incentives, and therefore need more equity incentives in order to exert optimal effort. In their view, the relation between pay and performance is simply too small to provide significant incentives for the manager. Ever since, executive stock options have become increasingly popular because they tie management compensation to the degree of wealth creation for shareholders. Hall and Liebman (1998) and Core and Guay (2002) have hitherto pointed out that equity incentives and, in particular, stock options are the dominant components in CEO pay packages in the U.S.

Stock option compensation is popular for at least three reasons. First, from the firm's perspective, it offers a favorable accounting treatment compared to cashbased compensation, at least for the time period under investigation here (see Carter, Lynch, and Tuna, 2007). Second, from the manager's perspective, capital gains from equity based compensation are taxed to a lower extent than personal income derived from a regular salary. Third, from a shareholder perspective, equity compensation (either via stocks, stock options or a combination of both) can be a powerful incentive for tying management compensation to shareholder wealth creation. This is confirmed empirically by Core and Larcker (2002), who document a significant increase in performance and valuation of firms adopting mandatory stock option plans-so called "target ownership plans". Kato et al. (2005) conclude that the introduction of executive stock options in Japan has brought significant improvements in terms of operating performance. Thus, well-designed incentive plans are "consistent with the creation of shareholder value" (Kato et al. 2005, p. 460). Moreover, Coffee (2005) points at institutional investors putting pressure on firms to adopt stock option plans. 
Despite the obvious benefits of equity incentives, the literature on corporate governance critically questions whether these are (unanimously) achieved. In particular, some claim that certain governance mechanisms such as the market for corporate control are inadequate and provide CEOs with the ability to influence their own pay. Core, Holthausen, and Larcker (1999) find that in "poor" corporate governance structures, managers can set their own remuneration packages, which ultimately leads to inferior performance. With the use of survey data, Géczy, Minton, and Schrand (2007) further establish that companies with weak shareholder rights (a high G-index) induce excessive managerial risk-taking because managers' equity-based compensation can be seen as a call option on the firm's assets, where the value of the option increases with volatility. The authors find that directors of companies with a high G-index tend to engage more in speculative trading-instead of hedging - for their own benefit rather than the company's. They note that a distinctive feature of a "speculating" versus a "non-speculating" firm is the use of short-term equity incentives.

These findings indicate that some governance structures provide the CEO with discretion. If this is exploited, the manager receives "excessive" option compensation and has excessive risk-taking incentives. If the CEO aims to maximize his compensation he will bargain for option incentives and increase firm risk. ${ }^{2}$ But shareholders as residual claimants to the firm's cash flows become discontent about excessive risk-taking by the manager. The reason lies in informational asymmetries and market frictions, which inhibit outside shareholders' inference on the true state of the firm. The situation in our paper is therefore a variant of Miller and Rock's (1985) proposed model of investment and dividend policy. The crucial difference is that market participants are unable to infer an optimal (in this case Fisherian investment) firm policy. Existing shareholders can potentially benefit from this and sell their shares at high prices but managers can time the release of information strategically. As a consequence neither existing nor outside shareholders are aware of the true state of the world. We interpret this form of risk-taking and behavior as harmful to outside and existing firm shareholders and beneficial to corporate insiders. ${ }^{3}$

Although a solution to this problem might be to simply change the governance structure, this is incredibly difficult to achieve. Large shareholders might be able to induce pressure on management in the form of "voice" or "exit"

\footnotetext{
${ }^{2}$ Even though a risk-averse manager with discretion might find it optimal to set his own pay to safe cash compensation, we assume that this does not hold in the presence of asymmetric information. This situation covers the possibility that the manager has the flexibility to influence the stock price and consequently capture the upside of his performance-sensitive payoff. This setting finds theoretical support in Peng and Röell (2008b).

${ }^{3}$ By construction the equity-aligned manager gains in this situation because he can time his selling strategy.
} 
(Gillan and Starks, 2000; Edmans, 2009). But an active blockholder can also "overmonitor" the CEO and thereby induce him to exert suboptimal effort (Burkart, Gromb, and Panunzi, 1997). By construction, these actions are not available to dispersed shareholders with small ownership stakes - at least their credibility and impact is dwarfed by blockholders' actions. ${ }^{4}$ As a result, small investors have two alternatives according to Becht, Bolton, and Röell (2003). On the one hand, a proxy fight, which allows rebellious shareholders to remove corporate boards protected by takeover defenses (Comment and Schwert, 1995), is seldom used (Mulherin and Poulsen, 1998). On the other hand, shareholder suits have recently received mounting attention. Shareholder suits (or class-action lawsuits) can be initiated by a single shareholder, if shares have been bought at allegedly inflated prices and stock market performance has been consequently poor and contrary to management's (positive) statements. In 1995, the Private Securities Litigation Reform Act (PSLRA) was put into place, which enables shareholders to allege any violation of Rule 10(b)-5 of the 1934 Securities Exchange Act. This rule proscribes, among other things, "the intent to deceive, manipulate, or defraud with misstatements of material fact made in connection to financial condition, solvency and profitability." In this paper, we argue that the threat of a class-action lawsuit is a disciplining mechanism in case prior governance mechanisms have failed, or are not available, or are inefficient. Since our database spans the post-PSLRA period, the heightened pleading requirements for plaintiffs, which discourage frivolous lawsuits that are triggered by lawyers' incentives rather than shareholders' (Johnson, Nelson, and Pritchard, 2007), lends further credibility to our argument.

A closer look at the United States' institutional environment reveals that the occurrence of shareholder litigation and the use of incentives are intertwined. Historically, shareholder litigation is more prevalent in the United States than in other financial markets. Even though studies differ, each shows a rapid increase in financial statement restatements. One important characteristic that contrasts the United States as a regime of dispersed ownership to concentrated stock market regimes is a stronger reliance on variable compensation such as executive stock options and equity sharing programs (Coffee, 2005). On the one hand, this has increased the 2001 mean CEO pay to four times the level in the beginning of the 1990s but on the other hand it has also led to a focus on managing for short-term equity value (Hall, 2003). ${ }^{5}$ If at some point shareholders believe they have been misled according to Rule 10(b)5, they can take corrective action by suing the firm.

\footnotetext{
${ }^{4}$ We stress that even some institutional investors do not dispose of the options of "exit" and "voice." This is because they are low-turnover (high-trading cost) indexed funds (Bushee 1998) and/or funds, which find active monitoring too costly for other investors to free-ride on the activist's monitoring effort (Admati and Pfleiderer 2009)

${ }^{5}$ In 2001 the equity component of total CEO compensation for the S\&P 500 industrial companies constituted $66 \%$.
} 
Recent developments in financial markets have accelerated the occurrence of classaction lawsuits. The burst of the internet bubble has resulted in a large number of dissident and discontent shareholders. According to The Economist (19 December 2007), class-action lawsuits were filed on an "annual pace of around 270 between August and October 2007'. We note that the United States as a system of dispersed ownership plays a special role. In fact, class-action lawsuits are initially filed predominantly by individual rather than institutional investors. ${ }^{6}$

We proceed with the empirical analysis of our main theoretical argument in three steps. In the first step, we seek to address whether stock option incentives are driven by governance factors in addition to traditional economic determinants. Although a relation between governance factors and stock options is no evidence of suboptimality, our purpose is also not to seek such evidence. We seek to identify that component of stock option incentives that is likely driven by discretion executed by the CEO and can as such be interpreted as "excessive." To achieve this purpose, we follow the methods used by Core, Holthausen, and Larcker (1999) and more recently by Bowen, Rajgopal, and Venkatachalam (2008) and focus on governanceinduced option incentives.

In the second step, we analyze the consequences of these governanceinduced option incentives with respect to the occurrence of class-action lawsuits acting as a disciplining threat to managers. We interpret the occurrence of a classaction lawsuit as a proxy for the enforcement of a governance mechanism, the threat of which disciplines management ex ante. The probability of a class-action lawsuit in this study is very much like the probability of CEO termination in turnover studies (among others Yermack, 2006b). As a result, we hypothesize that the likelihood of class-action lawsuits is higher the greater the component of stock option incentives that is driven by corporate governance factors.

In our last step, we examine whether the demand for class-action lawsuits to act as a disciplining threat to CEOs is time-varying. The passage of the SarbanesOxley Act in 2002 has introduced higher personal penalties for CEOs who are accused of price manipulation. Inarguably, the enforcement of the Act has changed the institutional and legislative landscape for corporations and managers. The introduced personal liability of directors and officers poses an additional threat, forcing CEOs to manage in the shareholder interests in order not to be personally sued. This additional threat acts as a cost-efficient substitute for class-action lawsuits after SOX. As a result, we hypothesize that the relation between governance-induced option incentives and the occurrence of class-action lawsuits is less pronounced

\footnotetext{
${ }^{6}$ The random sample of 128 firms (20\% of our total sample) in our sample of class-action lawsuit firms shows that $82 \%$ of the lawsuits were initially filed by individual investors with the remainder being initiated by pension funds, trustees, and other companies.
} 
post-SOX compared to pre-SOX, because SOX introduces a substitute disciplining mechanism.

Our empirical results are consistent with the theoretical arguments put forward here and provide several contributions to the literature. First, by combining two strands of research our paper contributes to the literature on shareholder litigation and CEO compensation. We interpret class-action lawsuits as a governance mechanism available to minority shareholders in order to monitor the CEO. We document that certain elements of corporate governance bear a significant incremental explanatory power in determining CEO equity-based incentive levels. These governance-induced levels of option incentives exhibit a strongly positive influence on the probability of being subjected to a class-action lawsuit and thus to shareholders taking action. Not only does this component of equity incentives affect the likelihood of being sued, it also drives the severity of lawsuits in terms of the number of allegations that the corporation faces. Assuming the manager is aligned with equity implies that he inevitably cares about the stock price. We state that lawsuits are at least successful in punishing the equity-aligned manager ex post due to negative stock price effects irrespective of the type and legitimacy of the allegation. Thus, our paper rejects the claim of Armour et al. (2009), who state that lawsuits in the United States are comparatively ineffective in enforcing private law.

Second, our interpretation of a class-action lawsuit as a governance mechanism is in contrast to previous studies that interpret it as a "bad performance event." For example, Peng and Röell (2008a) use one specific type of class-action lawsuit as a proxy for price manipulation. Such an interpretation conceptually ignores the disciplining potential of class-action lawsuits that we put forward in this paper. However, more importantly, interpreting class-action lawsuits as bad performance events is inconsistent with the empirical results provided in this paper. If class-action lawsuits were merely bad performance events, then we should only observe a drop in class-action lawsuits due to SOX (intercept effect). The finding that the relation between governance-induced option incentives and the occurrence of class-action lawsuits changes due to SOX (slope effect), is consistent with classaction lawsuits acting as a governance mechanism.

Third, our findings have important implications for shareholders, policymakers and external monitors in designing CEO incentive schemes. We emphasize the relevance of class-action lawsuits as an available governance tool and monitoring mechanism for small investors. A further contribution is that this effect is significantly less pronounced after the Sarbanes-Oxley Act (SOX) and has introduced higher personal penalties for directors being eventually convicted of financial fraud. We complement Chhaochharia and Grinstein (2007), who point out a positive valuation effect for SOX. Despite being criticized for being increasingly 
burdensome for companies to comply to SOX, we hence present a benefit; a disciplining mechanism in Sections IX, XI, XIII, which impose higher penalties for financial fraud and insider trading committed by directors and officers. We conclude that SOX offers an additional external disciplining threat for managers engaging in excessive risk taking due to excessive incentives and entrenched boards.

In the context of Gompers, Ishii, and Metrick (2003), we also offer an additional explanation for the higher valuation of "well-governed" companies. Karpoff, Lee, and Martin (2008a \& b) show that class-action lawsuits and possible SEC enforcement actions have materially adverse effects on managers and the companies as well. According to our results, companies with weak shareholder rights have potentially discretionary compensation schemes and therefore face a higher litigation risk. This higher risk causes a lower stock market valuation.

The remainder of the paper is organized as follows: In Section 2, we describe the data, the construction of the main variables and our empirical analysis. Section 3 provides evidence of the association between governance structures, managerial discretion, and equity incentives. Here, we also show how equity incentives relate to the occurrence of class-action lawsuits and the potential severance pay from them. We further investigate the passage of Sarbanes-Oxley Act with respect to class-action lawsuits triggered by equity incentives. In Section 4 we discuss our results in a governance and regulatory context. A brief conclusion follows.

\subsection{Data and Empirical Approach}

\subsubsection{Class-action lawsuit data}

We obtain our information on class-action lawsuits from the website of Stanford Law School, which - in collaboration with Cornerstone Researchcompiles data on the filing date, number and identification of lead plaintiffs, trial outcome (if applicable), and the reason why shareholders sue the company. ${ }^{7}$ Since the initiation of the PSLRA of 1995, shareholders have the right to take managers to court upon violation of the Securities Exchange Act of 1934. Violations like these typically are the dissemination of false and misleading statements, artificial stock price inflation (for the purposes of accelerating mergers and takeovers and benefiting from IPOs and SEOs at the expense of new shareholders), accounting violations, insider trading, or even governance problems. Since 1996, the database includes more than 2,600 companies, which are listed on the NYSE, AMEX or the NASDAQ. The database also includes private and OTC-traded companies as well as

\footnotetext{
${ }^{7}$ This database is publicly available via http://securities.stanford.edu.
} 
foreign issuers (who consequently also fall under U.S. securities-law regulations). Unlike Fich and Shivdasani (2007), we decide not to exclude class-action lawsuits related to insider trading because we consider governance- and compensation-related cases to be particularly relevant to our study.

We hand collect case by case information and identify seven main reasons for shareholders going to court against the corporation. These reasons are listed in Table 3.1 below. Note that these allegations are not mutually exclusive. We also identify whether a so-called "triggering event" has preceded the class-action lawsuit filing. We classify triggering events as events where a material correction of management's earnings forecasts takes place before the filing date of the classaction lawsuit. Alternative triggering events can be the initiation of a SEC investigation, self-disclosure of accounting problems, resignation of the $\mathrm{CEO} / \mathrm{CFO}$, or severe problems in the auditing process. This definition aligns with our previously alluded to concept that these are consequences of performance and risktaking rather than a prequel to lawsuits. In our final sample of 650 companies, a triggering event precedes the filing in over $55 \%$ of the cases. Thus, we already observe that a sizeable fraction of the initiated shareholder suits comes as a surprise to the market.

As can be seen in our table, we observe some clustering in the types of allegations. Failure to disclose or the dissemination of false and/or misleading information belong to the most prominent allegations. Typically both actions are performed with the motive of share-price manipulation. Observing more than 90 cases of insider trading confirms the study of Aboody and Kasznik (2000) and Yermack (1997), who conclude that CEOs strategically time the issuance of information according to the exercise date of their options. Allegations of insider trading in our sample typically include statements such as "management reaping proceeds from own equity (options) holdings and taking advantage of their inside information before releasing adverse facts to the public." The average number of allegations per class-action lawsuit between 1996 and 2007 is 2.15, the maximum number of allegations is six. ${ }^{8}$ Class-action lawsuits typically emerge when shareholders are notoriously discontent with stock market performance or if they feel they have bought shares at inflated stock prices. In Panel B, we point out that shareholder litigation is likely to be initiated by private and minority shareholders. If we investigate the number of class-action lawsuits per year in our database next to the major stock market indices' performances, we note an intriguing pattern.

\footnotetext{
${ }^{8}$ On May 6, 2005, a class-action lawsuit was filed against the internet company findwhat.com (formerly known as Miva). Here, the total number of allegations amount to six. Reference to this can be found at: http://securities.stanford.edu/1034/FWHT05_01/.
} 


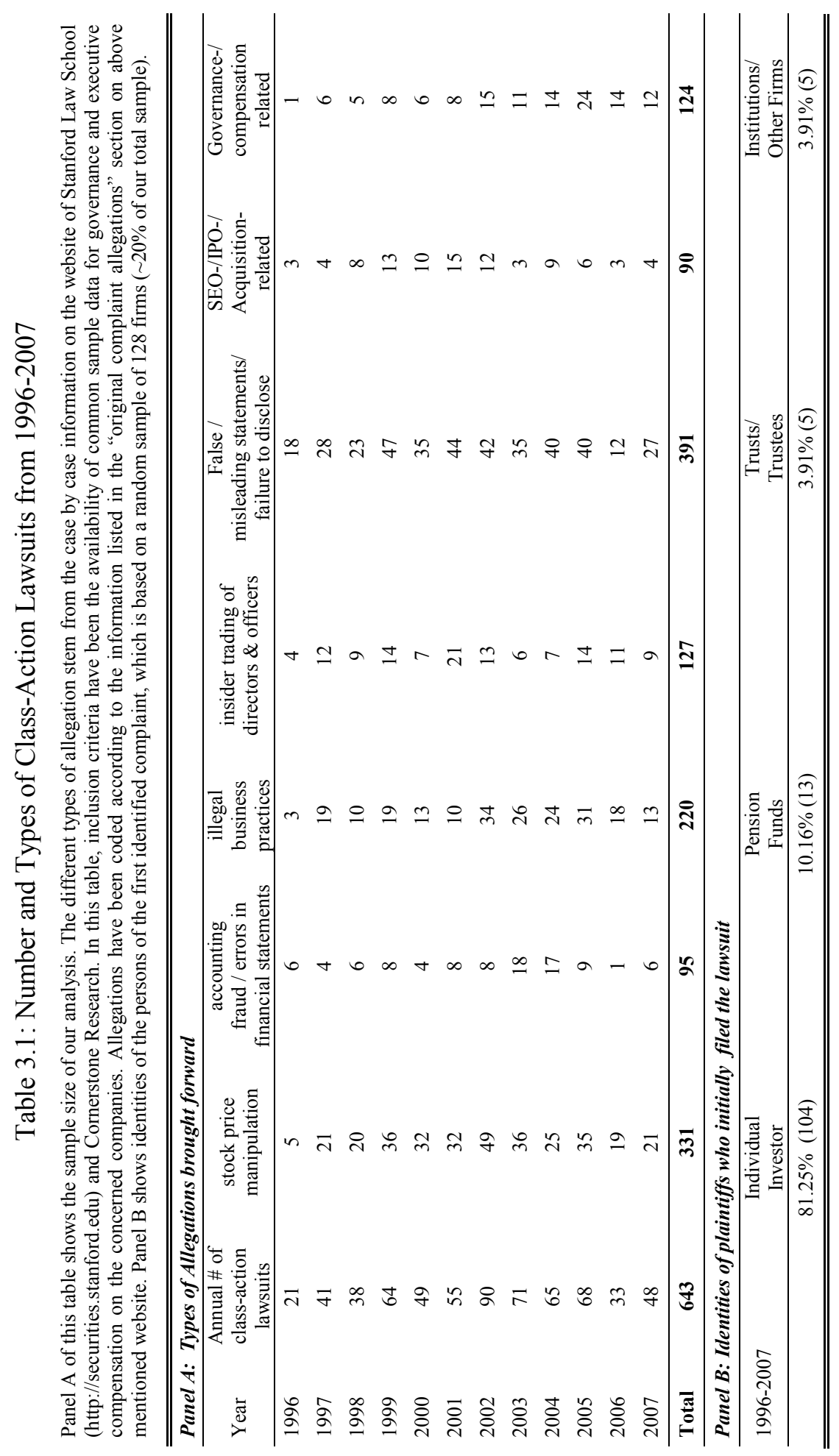




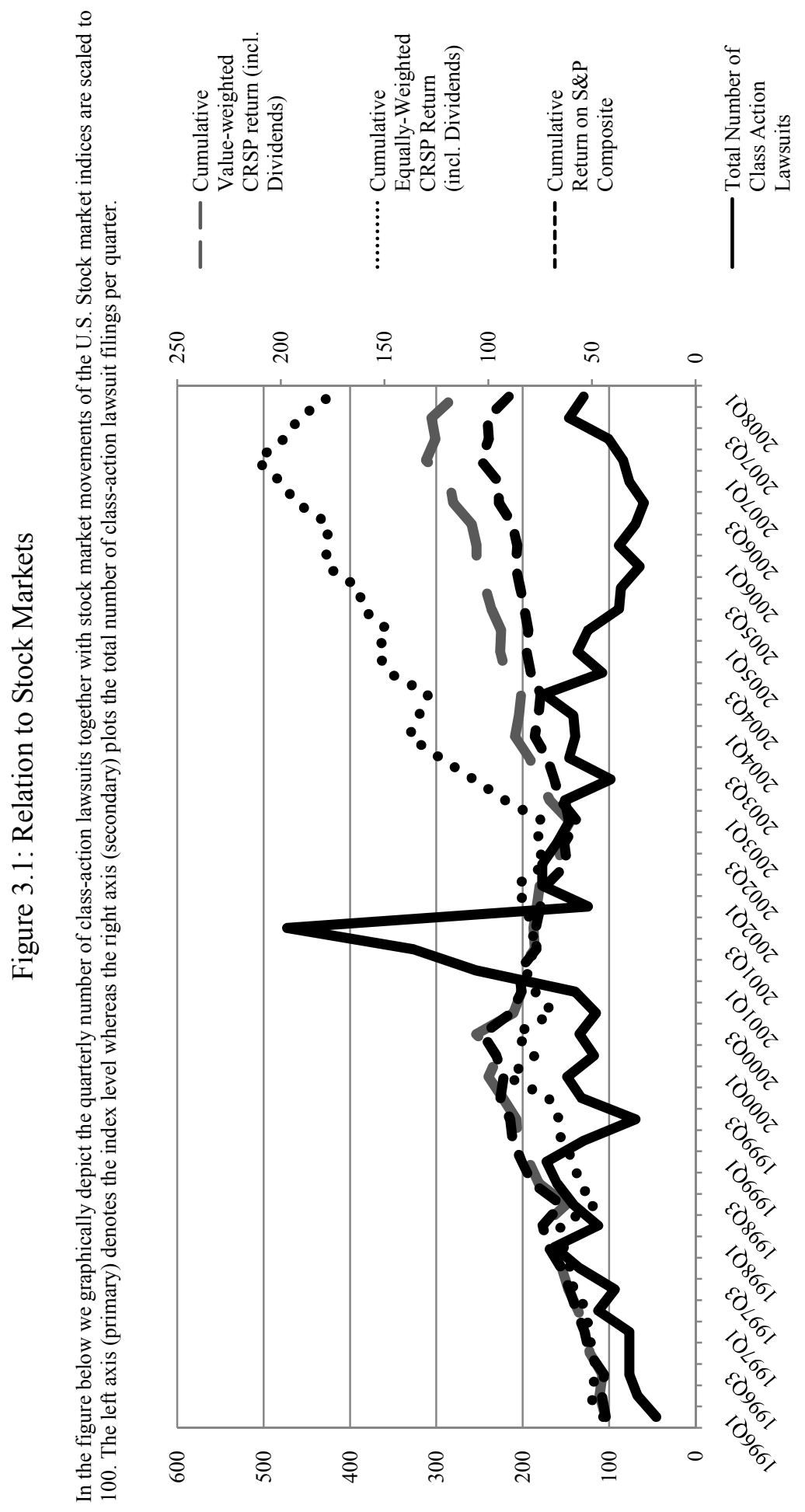


If we investigate the number of class-action lawsuits per year in our database next to the major stock market indices' performances, we note an intriguing pattern. In times of rising stock prices, shareholders appear to be indifferent about managers' potential wrongdoing. We can see this in Figure 3.1, for example, between 2005Q1 and 2007Q1. This is in line with the paper by Povel, Singh, and Winton (2007), who note that manager incentives to commit fraud are highest in times of good performances in stock price. This is due to the fact that shareholders' vigilance and monitoring incentives are lower in bull markets and higher in bear markets. After 2001Q1 we note a sharp increase in the number of class-actions reacting to the declining stock market. This increase might also be partly due to prominent governance failures and accounting scandals since then. We also observe the increase in the amount of shareholder litigation in the very recent past (2007Q1 through 2008), which is attributable to the subprime crisis. Previously, there had also been a sizeable amount of class-action lawsuits related to the option backdating scandal, which was disclosed in 2006.

Since 2000 several firms have restated their earnings in order to put right the wrongful accounting that followed backdating (The Economist 2006). ${ }^{15}$ Note that, typically, management is sued with a small time lag upon revelation of negative news (triggering events). The average time between a triggering event and classaction lawsuit filing is 90 days (median 28). For 310 companies in the sample this duration is basically zero because there was no triggering event reported. In order to investigate influences of corporate governance and compensation elements on classaction lawsuits, we construct two samples for which we find sufficient data. Our additional databases are further outlined in the next section.

\subsubsection{Governance data, financial control variables and equity incentives}

Our second data source stems from the RiskMetrics Group, which compiles annual corporate governance information on all companies in the S\&P 1500 in the United States. ${ }^{16}$ Hence, we investigate a broad index, which spans all types of industries and sectors. Data is purely descriptive and neither rating nor weighting algorithms are included. The governance variables are composed of board characteristics, elements of board composition and variables of takeover defenses, and entrenchment mechanisms. Our list of governance variables can be found in our Appendix A and for most definitions and explanations we refer to Appendix A of

\footnotetext{
${ }^{15}$ In the article "Dates from Hell," The Economist has put forward that in mid-2006 up to 60 firms were subject to SEC investigation for their timing of executive stock options

${ }^{16}$ This database was formerly known as the Investor Responsibility Research Centre (IRRC) and was, among others, the foundation of "Corporate Governance and Equity Prices" by Gompers, Ishii, and Metrick (2003).
} 
Gompers, Ishii, and Metrick (2003). We control for financial-, firm- and casespecific factors with data from COMPUSTAT. Our inclusion of control variables is based on prior research by Peng and Röell (2008a), Fich and Shivdasani (2007), Agrawal and Chadha (2005) and Dechow, Sloan, and Sweeney (1996). Our database on executive compensation is from Standard and Poor's ExecuComp The variable of equity-based incentives can be interpreted as follows: Assume the CEO holds a portfolio of stocks and stock options in the company that he manages. How much does the value of this portfolio change with a one percent change in the firm's stock price? We subdivide this variable into equity-only, stock-option-only, and totalportfolio-value incentives. We take the natural logarithm of this value for distributional convenience. Please refer to Core and Guay (2002) to find a detailed description of equity incentives.

\subsubsection{Estimation Method}

We regress the level of equity incentives (total-wealth, stock-option or stocks-only) on economic factors and governance variables. We seek to explore if some governance structures provide the CEO with discretion to negotiate for "excessive" option packages. We identify these as the portion of incentives that is not driven by economic (firm) variables:

$$
E I_{i t}=\alpha_{i}+\sum_{j=1}^{J} \beta_{j} \operatorname{Gov}_{j, i t}+\sum_{k=1}^{K} \gamma_{k} C_{k, i t-1}+\varepsilon_{i t},
$$

where $E I_{i t}$ equals the level of equity incentives (total-equity incentives, stock-based equity incentives or stock-option equity incentives) and $G o v_{j, i t}$ equals a set of governance variables as shown in Appendix A. The $C_{k, i t-1}$ is a vector of control variables (also lagged by at least one period), which are described in Appendix B of this paper. From this regression, we predict the level of "excessive" CEO equity incentives, which are determined by corporate governance structures of firm $i$ in excess of economic determinants. We compute these for every CEO in our sample for every year $t$. By using this method, we follow Core, Holthausen, and Larcker (1999). We use governance-induced equity incentives (via stock and/or stock options) and interpret these as managers' propensity for risk-taking and discretion. Each predicted variable follows from a set of governance variables that resemble managerial discretion and entrenchment. In total, our prediction model will generate three different levels of equity-based incentives for each CEO in each year. Our focus will be on the stock-option component of the following model:

$$
\text { EIpred }_{i}=\sum \hat{\beta}_{j} \text { Governance }_{i}
$$

As can be seen, EIpred $_{i}$ is the predicted level of equity incentives from governance variables. We distinguish our approach from other authors (Peng and 
Röell, 2008a; Bergstresser and Philippon, 2006) who use the raw level of equity incentives or the residual from the regression. In our setup, we are able to isolate the component that is driven by insiders and managerial discretion. These predicted values will enter into a next-stage regression, when we estimate the probability of being sued based on financial and control variables and the predicted equity incentives. As a next step we analyze the consequences of governance-induced option incentives with respect to the occurrence of class-action lawsuits. For that purpose we estimate the conditional probability of being sued and claim this to be the enforcement of a governance mechanism to pose a disciplining threat to CEOs. Our control sample is constituted by firms that are not sued in that respective year and the year before. We adopt a binary probit model of the following form:

$$
\operatorname{Prob}(Y=1 \mid x)=\frac{e^{x \prime \beta}}{1+e^{x \prime \beta}}
$$

where $Y=1$ if a class-action lawsuit was filed against the firm and zero otherwise. The $x$ is a vector of the equity-based incentive variables and control variables, and $\beta$ is the vector of parameters. Control variables are lagged by at least one period just like the variable of equity-based incentives. Our estimation method is a maximum likelihood and we control for year- and industry effects. In order to retain model parsimony, we opt for the Fama-French 12-industry classification. This approach has already been used before by Pagano, Panetta, and Zingales (1998) for firms' decisions to go public versus staying private.

\subsection{Empirical Analysis}

\subsubsection{Descriptive statistics}

We start our analysis with univariate comparisons of two sample groups. One constitutes the class-action lawsuit sample, which we outlined in Section 3.2, but our control sample incorporates the universe of non-sued RiskMetrics-rated (S\&P 1500) companies. The statistics of our sample can be found in the table below. Restricting the analysis to firm characteristics and operating performance, we note several observations. Firms being involved in class-action lawsuits are significantly larger, both in terms of total assets and sales revenue. We also notice a slightly better operating performance in terms of three-year sales growth but a significantly worse stock price performance over the prior calendar year. Firms in the class-action sample are also significantly more likely to have engaged in a major new equity issuance (more than 10\% increase in stockholders' equity) in the prior calendar year. 


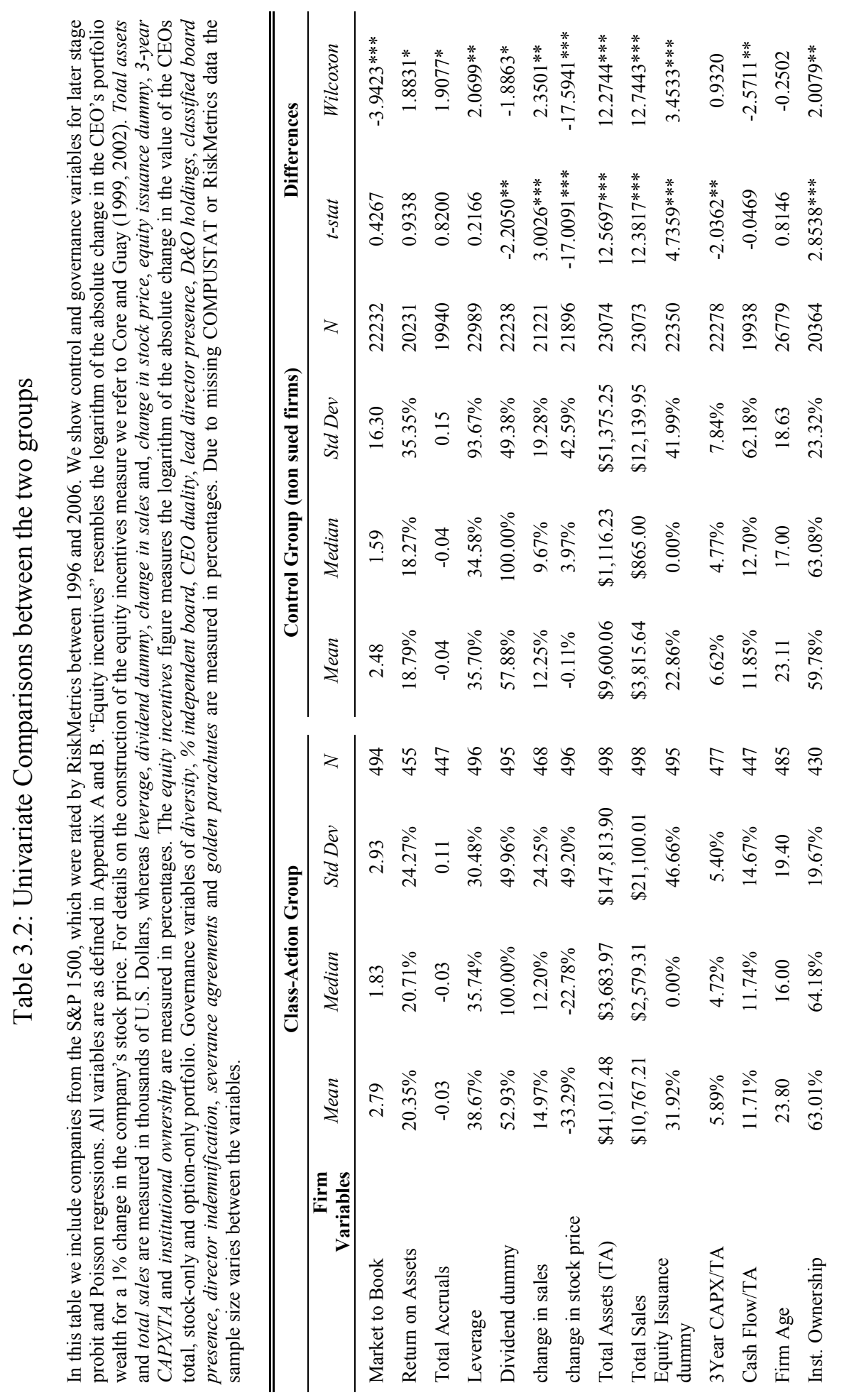




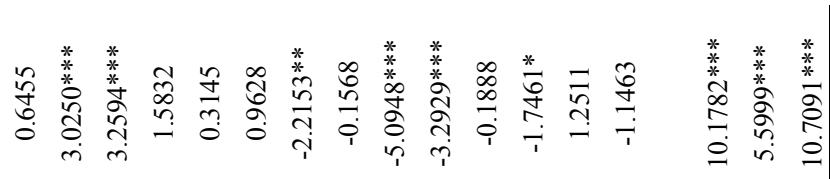

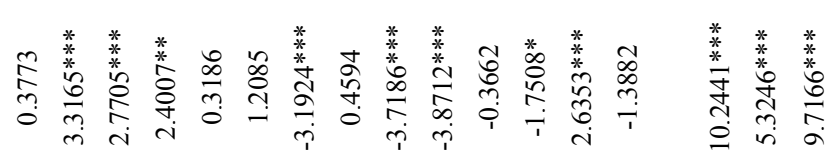

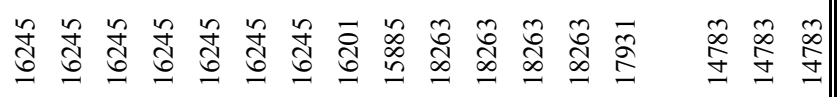

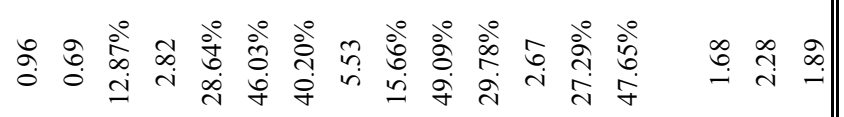

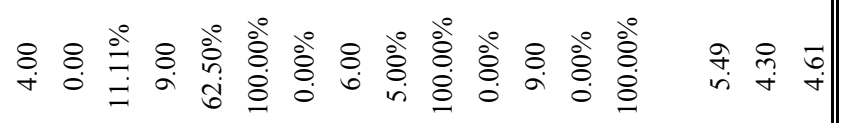

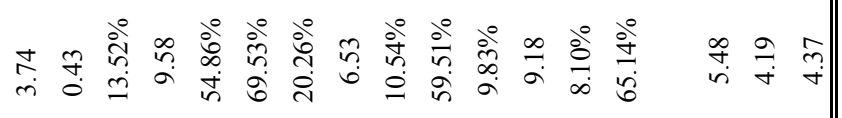

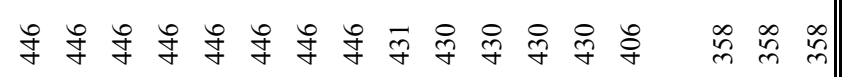

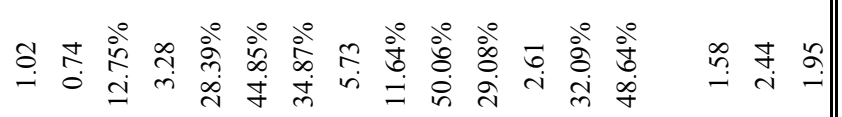

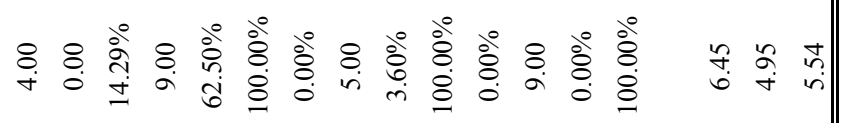

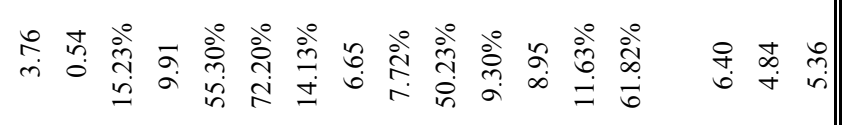

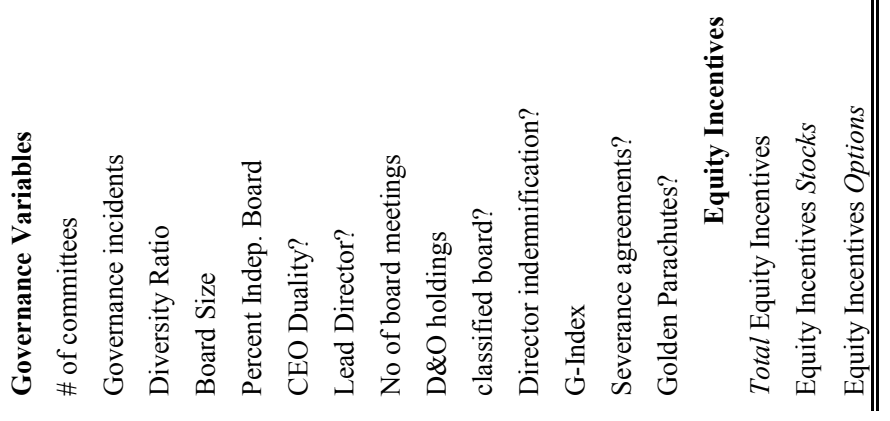


This is in line with shareholders' allegations of managers exploiting overvalued share prices in order to reap personal benefits in seasoned equity offers or to use the inflated stock as an "acquisition currency." The latter allegation is in line with managers' tendency to engage in empire-building activities. Firms hardly differ in terms of operational performance or investment behavior, because cash flow to total assets, return on assets, and trailing three-year capital expenditures relative to total assets, respectively, hardly differ among the two groups. Focusing on the governance variables, our samples do not display strong differences. Most importantly the G-index (the number of entrenching and shareholder-unfriendly provisions) is in fact lower (resembling stronger shareholder rights) for class-action lawsuit firms. However, sued firms are more likely to have suffered from so-called "governance incidents." The degree of director and officer voting rights is significantly higher in the control sample and well above 5\% for both samples. Ofek and Yermack (2000) note that in more than half of America's corporations' directors own less than $5 \%$ combined of a firm's outstanding shares.

However, most relevant differences between the class-action sample and the control sample are in the sensitivity of the CEO's wealth to changes in the stock price of the company. This sensitivity captures in our setting the extent to which the CEO can benefit from an artificial inflation in the share price of his company. The level of equity incentives is significantly higher for all three measures of equity incentives. We distinguish between total equity incentives, equity incentives derived from the CEOs' stock portfolio, and payoffs derived from the option portfolio. For all three variables, we note statistically significant differences in both mean and median values. An exponential transformation of, for example, mean values of total equity incentives of 6.39 and 5.48 (for class-action and control sample, respectively) results in a total wealth change for the CEO of \$599,922 USD and \$239,846 USD, respectively for a $1 \%$ change in the stock price. For the stock option part, we find $\$ 211,896$ USD and \$79,154 USD, hence almost three times higher.

\subsubsection{Announcement returns of class-action lawsuit filings}

We now turn to the potential of shareholder litigation to penalize the CEO ex post and the credibility of the ex ante threat. Prior research has established that the announcement of a class-action lawsuit filing leads to a negative return on the event date. The magnitude varies though depending on which types of lawsuits are included. In general, we identify four empirical studies that amplify the credibility of threatening to file class-action lawsuits ex ante and the disciplining power ex post. A summary of each of these studies and the central message to each of these papers can be found in Table 3.3 below. 


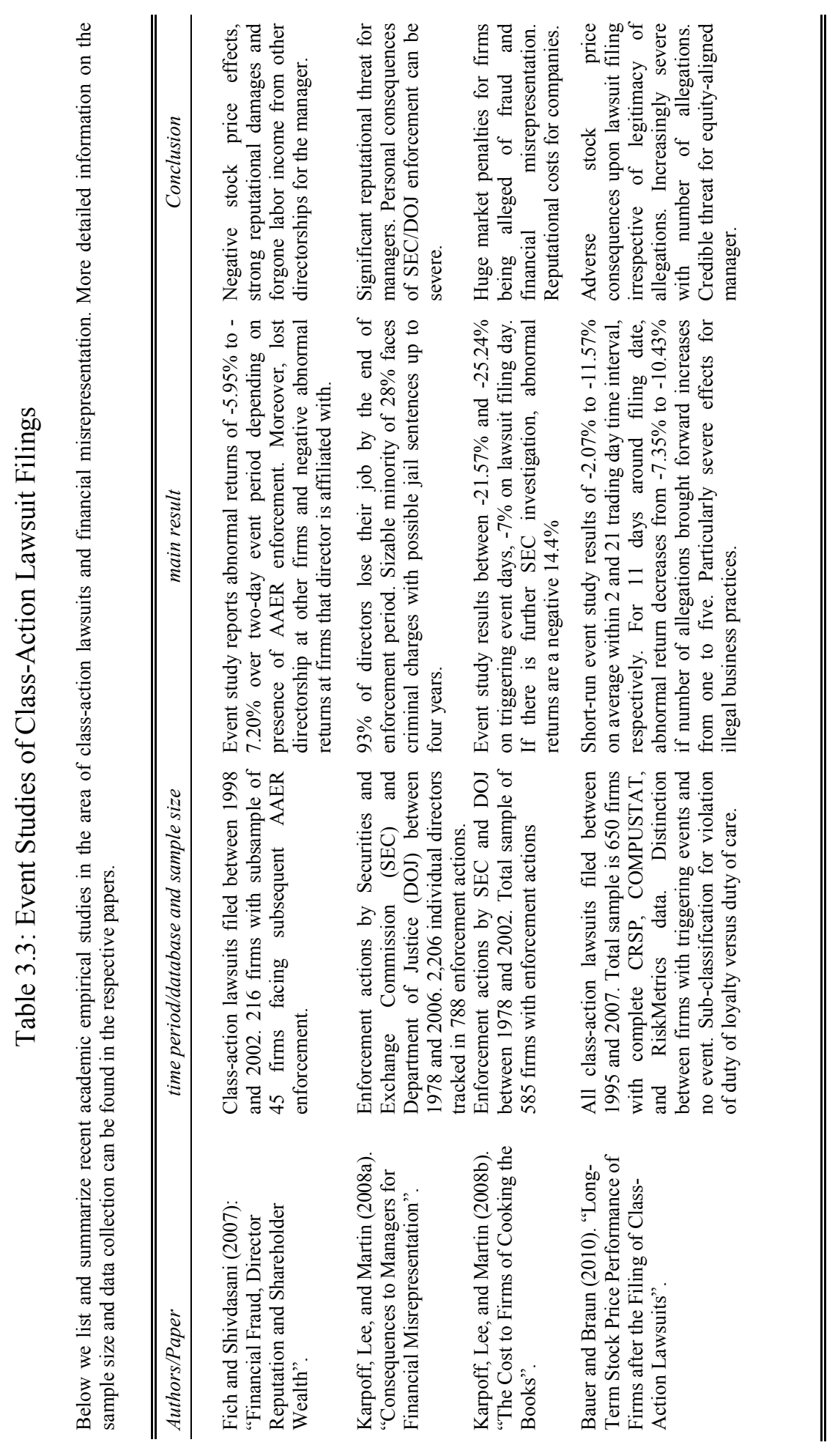


In their sample Fich and Shivdasani (2007) find two-day cumulative and announcement day abnormal returns ranging between $-5.95 \%$ and $-3.25 \%$, respectively. These can even be lower depending on whether an Accounting and Auditing Enforcement Release (AAER) was issued or the settlement amount has been in the top quartile. The authors stress that there are also significant reputational effects at work in the form of lost directorships on other boards. Similar conclusions emerge from Karpoff, Lee, and Martin (2008a). Focusing on companies that face SEC and DOJ enforcements between 1988 and 2006, 93\% of the 2,206 individual directors in 788 companies had lost their jobs by the end of the enforcement period. In a related paper with a shorter time window, Karpoff, Lee, and Martin (2008b) state that the initiation of class-action lawsuits is usually preceded by triggering events. Their study on these triggering events between 1988 and 2002 yields an abnormal return of $-25.24 \%$, the subsequent class-action lawsuit was $-7 \%$, and further criminal (SEC) investigation announcements result in $-14.4 \%$. The aforementioned three studies all investigate performance effects conditional upon the fact that allegations have been ex post legitimate. Using the exact same database as our study, Bauer and Braun (2010) document significantly adverse announcement effects irrespective of the legitimacy of allegations. In their study, the authors basically only distinguish between the type and the number of allegations generated by shareholders. The more allegations brought forward, the more severe is the stock price reaction. Controlling for economic factors, the authors find a particularly pronounced negative stock-price reaction for illegal business practices and insider trading allegations. Our conclusion from these studies on class-action lawsuits is that there is a credible ex ante threat to the equity-aligned manager.

\subsubsection{Quarterly Performance Volatility Between Groups}

From Table 3.2, we conclude that companies facing a class-action lawsuit have superior past operating performance. If CEOs and directors have an "excessive" incentive and discretion to inflate stock prices by issuing materially false information, failing to disclose adverse events, taking on irresponsible project risk, or by manipulate accounting numbers, this will result in higher performance volatility. When true performance is disclosed the stock price adjusts back to fundamental levels from its heavily inflated levels. Managers holding a substantial amount of stock options have an incentive to increase the volatility of performance. Therefore we analyze the firms' past operating and stock-price performance and volatility in greater detail. We use COMPUSTAT Quarterly files and data from Standard and Poor's ExecuComp in order to investigate how class-action lawsuit firms' prior operating-performance volatility compares to our control sample. The results are shown in Table 3.4. 


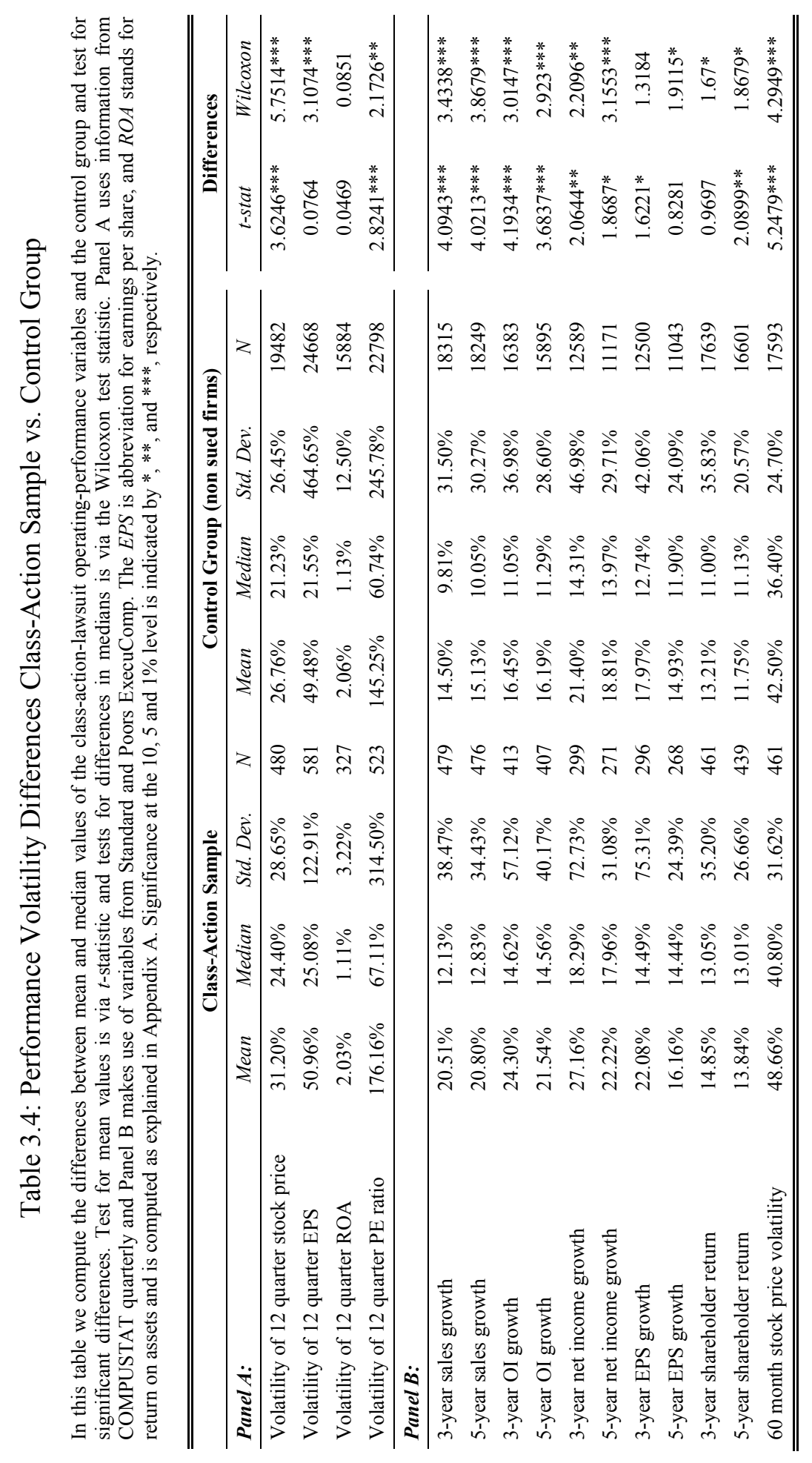


In Panel A, we report variables from COMPUSTAT Quarterly files of the 12 quarters prior to the class-action lawsuit filing. This time frame also incorporates the period long before the mean date of the triggering event. Here, the stock price, earnings per share (EPS), and price-earnings (PE-) ratios of the class-action group bear a significantly higher volatility than the control group both for mean and median values (except for EPS). Hence, both operating performance as well as stock market performance are more volatile for sued companies compared to our control sample of non-sued S\&P 1500 firms. This observation is reinforced by the 60 month stock-price volatility in Panel B. This value stems from ExecuComp and is the baseline for the calculation of the CEO stock option value.

Since a call option's value increases with volatility we can also easily see the CEO's motives for increasing the company's performance volatility. This finding is in line with Géczy, Minton, and Schrand (2007). The remaining values in Panel B confirm the operating performance patterns from Table 3.2. Companies, which were subsequently sued, display substantially larger growth in sales, operating performance, and net income. We stress the findings from Table 3.2 that these two types of companies do not differ significantly in terms of firm age, so that the possible explanation of young aspiring high-growth companies can be ruled out. Hence, from the inspection of raw data we can already confirm that firms who are sued by their shareholders have superior operating performance but are subject to higher firm risk prior to the filing date. Allegedly, managers forge performance levels or earnings forecasts and revenue recognition turn out to be too aggressive. These values are robust to controlling for industry effects (univariate sorts relative to the Fama-French 12-industry median values) since class-action lawsuits might tend to cluster in specific sectors that are marked by high growth and largely intangible assets.

\subsubsection{Who and What Determines Equity Incentives?}

As a next step we investigate whether equity incentives are determined by discretion and prevalent corporate governance structures. In the simple contracting perspective, shareholders determine managers' compensation levels and equity incentives-possibly through the board of directors (Bertrand and Mullainathan 2000). If managerial discretion does not have an influence on the CEO to bargain for steep incentives, then corporate governance must not have any significant incremental explanatory power over financial and firm characteristics. If we do observe that governance variables and board characteristics effect (option) incentives, then we interpret this portion of incentives as "excessive." Effectively, this procedure boils down to testing whether shareholders eventually care about incentives as long as they are driven by managerial discretion. Below, we regress the logarithm of equity incentives on a rich set of financial and governance variables- 
holding constant year- and industry effects - using OLS with heteroskedasticity consistent standard errors.

Economic reasoning and prior research motivate our inclusion of control variables (economic factors) and governance variables. Firm size (log TA) and book-to-market $(\log \mathrm{M} / \mathrm{B})$ have already been shown in Core, Holthausen and Larcker (1999) to have a significantly positive impact on equity incentives. We also control for firm age and institutional ownership (IO), prior operating performance (return on assets, ROA) and whether the firm is a dividend paying firm. In accordance with the literature we define institutional ownership as follows:

$$
I O_{i t}=\sum_{i=1}^{N_{i}} s_{i j t}
$$

where $s_{i j t}$ is the share $s$ that the institutional money manager $j$ holds in company $i$ at time $t$. Our governance variables of interest are the following. As shown by Stulz (1988) the relation between inside ownership and firm value is in theory curvilinear. With low managerial ownership, interests are not fully aligned with shareholders', and managers act on their own behalf.

If managerial ownership increases beyond a certain threshold, alignment becomes entrenchment. Even further increasing managerial ownership makes managers close to entrepreneurs where money spent on perquisites harms them in increasing proportion. We therefore complement the level of aggregate D\&OHOLDINGS with a quadratic term to capture non-linearity. Similar to the variable IO, we define D\&OHOLDINGS as:

$$
\text { D\&OHoldings } s_{i t}=\sum_{i=1}^{N_{j}} v_{i j t}
$$

where $v_{i j t}$ represents the fraction of voting rights $v$ that the director or officer $j$ holds in firm $i$ at time $t$. A further governance variable is board size. Yermack (1995) has shown that companies with larger boards are worth less on the stock market, therefore we expect a significant effect for this variable as well. Measures of CEO power (CEO duality and director indemnification contracts) and extraordinary remuneration (severance agreements and golden parachutes) help to augment the CEO's bargaining position and amplify managerial discretion. We seek to identify which of these are significant determinants in the granting of equity incentives. 


\section{Table 3.5: Economic and Governance Determinants of Equity Incentives}

This table shows results of three different ordinary least squares models. Model (1) regresses equity incentives of the CEO's option and stock portfolio on economic determinants, firm characteristics, board characteristics, board compensation and director powers elements. Equity incentives (equity incentives total) are defined as the change in wealth of the CEO's portfolio for a 1\% change in the firm's stock price. For details on the variable construction please refer to Core and Guay $(1999,2002)$. Model (2) performs the same regression with equity incentives of the CEO's stock portfolio (equity incentives stock) as the dependent variable, and model (3) has the regressor as the CEO's option portfolio (equity inc. options). Standard errors are adjusted for heteroskedasticity using White's method (1980). All models adjust for industry and time effects; the coefficients are omitted from the output for practical reasons. For the definitions of the variables, please refer to Appendix A and B. Significance at the 10, 5, and 1\% level is indicated by $* * *$, and $* * *$, respectively.

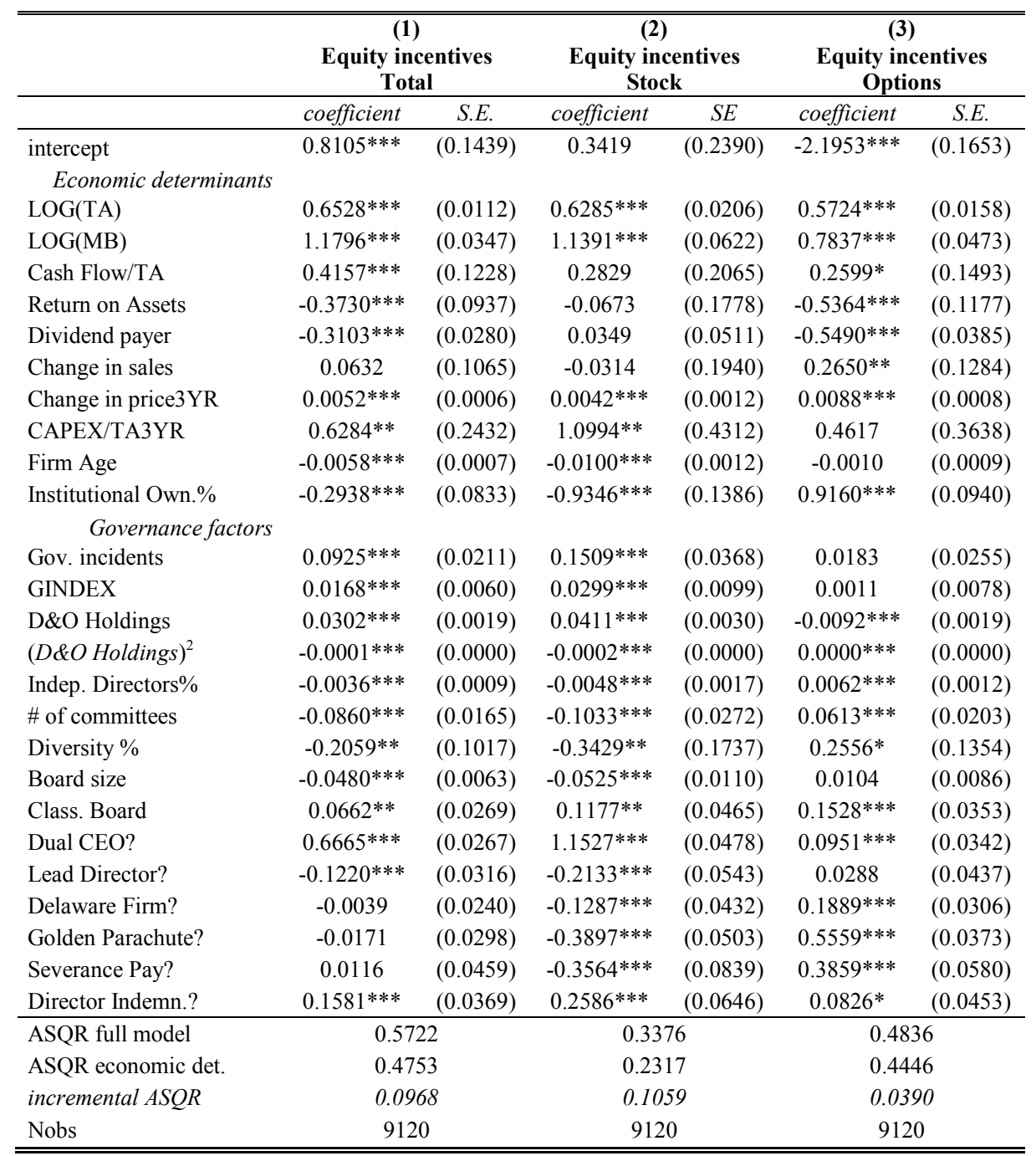


In Table 3.5, we regress both the total level of equity incentives (1) and the two components thereof, namely equity incentives of stock (2) and equity incentives of options (3), on a number of economic and governance variables. As expected, economic variables have a significant effect on equity-based incentives for the CEOs in the sample. Firm size as well as the market-to-book ratio have a significantly positive effect on the level of equity incentives for the CEO. The same holds for the three-year trailing stock price performance (change in price $3 \mathrm{Y}$ ). We proxy for firm age with the first listing date on CRSP and observe a negative and significant effect with respect to regressions (1) and (2) but not in (3). Prior corporate investment (CAPEX/TA3Y) activity is significant and positively related to equity-based incentives. This finding relates to a study by Grinstein and Hribar (2004), who analyze whether weak boards grant significant bonuses to their CEOs contingent on their M\&A and investment activity. However, this finding only holds for regression models (1) and (2). Observing a significantly positive coefficient for the percentage of institutional ownership (IO) on option incentives confirms the argument by Coffee (2005). He justifies the strong reliance on stock option compensation for America's CEOs as coming from institutional pressures.

Turning to governance characteristics, we observe that numerous variables contribute to explaining the incremental level of equity incentives. CEO duality has a strongly positive effect on equity incentives in all three specifications. The same holds for the presence of a classified board, which has a significantly positive effect in all three regression models. These findings also support Faleye's (2007) conclusion that managers use classified boards to grant themselves a higher pay-forperformance sensitivity. Bates, Becher, and Lemmon (2008) argue that institutional investors and joint shareholder initiatives are increasingly opposed to the adoption of classified boards. The percentage of independent directors on the board and total number of committees has a negative effect on the level of equity incentives. However, for regression (3) this effect is reversed. Remarkably, the diversity percentage of the board also has a significant effect: the influence is positive for stock option incentives and negative overall. We also note the significance of severance payments and golden parachutes. With those already in place, they both reduce equity incentives and increase stock option incentives. It is also quite astonishing to find numerous state legislations exhibiting a significant influence on pay-for-performance sensitivity. The Delaware incorporation effect (Daines, 2001) is apparently also present for executive compensation. ${ }^{17}$ Similarly, director indemnification contracts significantly increase the level of equity incentives, even though this finding is only mildly significant for stock option incentives. These

\footnotetext{
${ }^{17}$ In his paper, Robert Daines establishes robust evidence that Delaware firms are valued significantly higher than other firms. He explains this finding by the surprising evidence that Delaware companies are more likely to receive takeover bids, even though Delaware legislation is known to be particularly protective for incumbent management
} 
contracts indemnify directors and officers from certain legal expenses arising from their misconduct. The respective cost of this indemnity to shareholders can be seen as an incentive for corporate governance (Core 1997, 2000). A further intriguing result can be found for a company's G-index. This result can be observed in column (3), which means that high G-index (weak shareholder rights) firms grant significantly more option incentives to their CEOs than low G-index firms (strong shareholder rights). Judging from the additional explanatory power (incremental adjusted $R^{2}$ from governance variables) of the model, we conclude that governance structures contribute to the level of equity incentives in excess of firm-level and economic determinants. As expected, CEO pay-for-performance sensitivity is to some extent negotiated with managerial discretion. The question is about the consequences for shareholders and for the firm itself.

\subsubsection{The Consequences of Insider Determined Equity Incentives}

In order to test our second hypothesis we predict the incremental level of equity incentives in excess of economic and control variables. We use this governance-induced portion of performance-sensitive compensation in order to evaluate the probability of facing a class-action lawsuit. Core, Holthausen, and Larcker (1999) use the predicted level of excess cash and variable compensation to investigate future operating and stock-price performance. In our paper, we take a different point of view in that managerial discretion from governance structures drives incentives, which trigger shareholder litigation and, hence, investors' attempt to monitor the managers after prior governance mechanisms have failed or are unavailable.

We observe offsetting effects of stock and stock-option-based equity incentives. The negative coefficient of equity incentives stock and the significantly positive coefficient of equity incentives options imply that the overall equity incentive coefficient is nonsignificant. We find that incremental stock-option equity incentives, which are set by corporate governance structures and discretion, positively affect the likelihood of being sued below the 5\% level ( $z$-stat. 2.31). The opposite holds for stock only equity incentives. This variable is not significant. Apparently, incentives and variable compensation, which CEOs with little restriction can negotiate for, increase the level of risk-taking. This risk-taking triggers a governance mechanism channeled through allegations of securities fraud. Shareholders attempt to discipline the CEO ex post. 


\section{Table 3.6: Governance-Induced Equity Incentives}

This table shows results from three binary probit regression models per panel, where the dependent variable always equals one if a class-action lawsuit (CA) was initiated in that year against company $i$, and zero otherwise. Our estimation method is maximum likelihood. All models have the same set of economic determinants to predict the probability of becoming subject to a class-action lawsuit. We predict equity incentives as the incremental part of equity incentives that is explained by governance variables in excess of economic determinants. The Z-statistics are based on cluster-robust covariances according to Huber/White. The models include year and industry fixed effects but coefficients are not reported for practical reasons. Statistical significance at the 10,5 , and $1 \%$ level is indicated by *, **, and ***, respectively.

\begin{tabular}{|c|c|c|c|c|c|c|}
\hline & \multicolumn{2}{|c|}{ Probit: CA yes/no } & \multicolumn{2}{|c|}{ Probit: CA yes/no } & \multicolumn{2}{|c|}{ Probit: CA yes/no } \\
\hline & coefficient & S.E. & coefficient & $S E$ & coefficient & S.E. \\
\hline intercept & $-3.7095 * * *$ & $(0.2339)$ & $-3.7262 * * *$ & $(0.2275)$ & $-3.5440 * * *$ & $(0.2468)$ \\
\hline Accruals & -0.1692 & $(0.6118)$ & -0.1625 & $(0.6123)$ & -0.1576 & $(0.6068)$ \\
\hline Return on Assets & 0.0309 & $(0.3467)$ & 0.0305 & $(0.3468)$ & 0.0221 & $(0.3456)$ \\
\hline LOG(M/B) & $0.1602 * *$ & $(0.0643)$ & $0.1604 * *$ & $(0.0643)$ & $0.1718 * * *$ & $(0.0644)$ \\
\hline LOG(TA) & $0.1719 * * *$ & $(0.0179)$ & $0.1711^{* * *}$ & $(0.0176)$ & $0.1687 * * *$ & $(0.0175)$ \\
\hline Cash Flow/TA & -0.3124 & $(0.4361)$ & -0.3096 & $(0.4362)$ & -0.3257 & $(0.4307)$ \\
\hline Dividend pay & $-0.1689 * * *$ & $(0.0619)$ & $-0.1678 * * *$ & $(0.0620)$ & $-0.1740 * * *$ & $(0.0620)$ \\
\hline Equity issue & $-0.1268^{*}$ & $(0.0701)$ & $-0.1265^{*}$ & $(0.0701)$ & $-0.1271^{*}$ & $(0.0700)$ \\
\hline Change in sales & $0.0045^{* *}$ & $(0.0021)$ & $0.0045 * *$ & $(0.0021)$ & $0.0047 * *$ & $(0.0021)$ \\
\hline Change in price & $-0.0107 * * *$ & $(0.0009)$ & $-0.0107 * * *$ & $(0.0009)$ & $-0.0108 * * *$ & $(0.0009)$ \\
\hline CAPEX/TA3Y & -0.5442 & $(0.6438)$ & -0.5315 & $(0.6441)$ & -0.4656 & $(0.6447)$ \\
\hline $\begin{array}{l}\text { Equity incentives } \\
\text { total }\end{array}$ & -0.0266 & $(0.0496)$ & & & & \\
\hline $\begin{array}{l}\text { Equity incentives } \\
\text { stock }\end{array}$ & & & -0.0310 & $(0.0318)$ & & \\
\hline $\begin{array}{l}\text { Equity incentives } \\
\text { options }\end{array}$ & & & & & $0.1448 * *$ & $(0.0648)$ \\
\hline McFadden $R^{2}$ & \multicolumn{2}{|c|}{0.1510} & \multicolumn{2}{|c|}{0.1512} & 0.1523 & \\
\hline Nobs & \multicolumn{2}{|c|}{11961} & \multicolumn{2}{|c|}{11961} & 11961 & \\
\hline
\end{tabular}

We take the analysis a step further and also conduct a Poisson integer-count data regression of the number of allegations (that is, to proxy for the severity of the allegations and the likelihood of the allegations being well-founded), which are brought forward by shareholders on the same set of control, governance, and CEO equity-based incentive variables. In doing so, we test whether not only the likelihood of a lawsuit is affected by option incentives but also its potential severity. Recall from our earlier analysis that a higher number of allegations increasingly penalizes the equity-aligned CEO. We therefore approximate for a lawsuit's severity by the number of allegations brought forward by shareholders. A higher number of allegations might increase the potential final settlement amount. A Poisson 
regression model is a generalized linear model with a "log" link function and Poisson distributed errors (Greene 2003). This model attributes to a count response variable $Y$ and a Poisson distribution whose expected value depends on predictor variables $x$ in the following way:

$$
\log \mathrm{E}\left[Y_{i t} \mid x_{i t}\right]=\beta_{i} x_{i t}
$$

where $x_{i t}$ is a vector of regressors describing the characteristics of an observation unit $i$ (a company or executive compensation variable) during a given time period $t$, and $Y_{i t}$ is the observed event count (number of allegations) for unit $i$ in the classaction lawsuit filing. ${ }^{18}$ Our variables also have a significant explanatory power if we go beyond analyzing whether a firm becomes sued or not; it also determines the potential magnitude of the class-action lawsuit measured by the number of allegations brought forward by shareholders.

In Table 3.7, we observe that the severity of a potential class-action lawsuit also is higher (hence also its "punishment") in firms with high option incentives in the presence of managerial discretion. That means if strong option incentives induce managers to act for personal benefits, then the severity of class-action-lawsuit allegations also increases and possibly also personal consequences for managers. The potential severity of class-action lawsuits might in fact also lead to higher chances of success and possible legal enforcement. Karpoff, Lee, and Martin (2008b) show that the personal consequences for managers after regulatory enforcement (by the SEC and the DOJ) are material. Of the managers who lose their jobs, 93\% experience reputational damages and forgo significant amounts of future labor income. We conclude from these effects that threats evolving from potential class-action lawsuits are credible.

We conclude that the CEO's option incentives combined with insiderinfluenced boards indeed increase the probability of triggering shareholder litigation. Therefore the necessity for shareholders to discipline the managers via the threat of a lawsuit and to take influence via the actual filing is higher with larger governanceinduced option incentives. Given that in most cases class-action lawsuits allege managerial malfeasance, the question that arises is in how far managers can be held personally liable. Both active monitoring and the actual filing of a lawsuit are costly for investors. The analysis of our third hypothesis seeks to provide some answers. We argue that there is a more cost-efficient way to ex ante discipline CEOs and identify this in the SOX personal liability section. We add an interaction term of a post-SOX dummy together with the level of equity incentives in our three

\footnotetext{
${ }^{18}$ We also conducted a Tobit regression with a censored dependent variable. The results do not materially differ.
} 
measurements. We conduct the same regression as in table 6 and report the results in the table below.

\section{Table 3.7: Severity of Class-Action Lawsuits}

In this table we report three integer count regression models per panel, where the dependent variable always equals the number of allegations brought forward in the class-action lawsuit against company i. It ranges from zero to six. Our estimation method is maximum likelihood. All models have the same set of economic determinants to predict the severity of a class-action lawsuit. We predict equity incentives as the incremental part of equity incentives that is explained by governance variables in excess of economic determinants. We distinguish between equity incentives predicted by all governance variables. The Zstatistics are based on cluster-robust covariances according to Huber/White. The models include year and industry fixed effects but coefficients are not reported for practical reasons. Statistical significance at the 10,5 , and $1 \%$ level is indicated by $* * *$, and $* * *$, respectively.

\begin{tabular}{|c|c|c|c|c|c|c|}
\hline \multicolumn{7}{|c|}{ Equity incentives predicted from all governance variables } \\
\hline & \multicolumn{2}{|c|}{$\begin{array}{c}\text { Poisson: } \\
\text { \# allegations } \\
\end{array}$} & \multicolumn{2}{|c|}{$\begin{array}{c}\text { Poisson: } \\
\text { \# allegations } \\
\end{array}$} & \multicolumn{2}{|c|}{$\begin{array}{c}\text { Poisson: } \\
\text { \# allegations }\end{array}$} \\
\hline & coefficient & S.E. & Coefficient & S.E. & Coefficient & S.E. \\
\hline intercept & $-6.3788 * * *$ & $(0.3704)$ & $-6.3558 * * *$ & $(0.3613)$ & $-5.9550 * * *$ & $(0.3841)$ \\
\hline Accruals & 0.3536 & $(0.7630)$ & 0.3768 & $(0.7630)$ & 0.3662 & $(0.7595)$ \\
\hline Return on Assets & -0.0388 & $(0.3599)$ & -0.0401 & $(0.3598)$ & -0.0426 & $(0.3591)$ \\
\hline LOG(M/B) & $0.1927 * *$ & $(0.0854)$ & $0.1903 * *$ & $(0.0853)$ & $0.2097 * *$ & $(0.0854)$ \\
\hline LOG(TA) & $0.2978 * * *$ & $(0.0254)$ & $0.2939 * * *$ & $(0.0248)$ & $0.2848 * * *$ & $(0.0245)$ \\
\hline Cash Flow/TA & 0.2315 & $(0.5502)$ & 0.2432 & $(0.5506)$ & 0.2134 & $(0.5456)$ \\
\hline Dividend pay & $-0.3629 * * *$ & $(0.0906)$ & $-0.3616^{* * *}$ & $(0.0907)$ & $-0.3721 * * *$ & $(0.0907)$ \\
\hline Equity issue & $-0.2161 * *$ & $(0.0954)$ & $-0.2151 * *$ & $(0.0954)$ & $-0.2162 * *$ & $(0.0953)$ \\
\hline Change in sales & $1.0727 * * *$ & $(0.2515)$ & $1.0866^{* * *}$ & $(0.2519)$ & $1.1340 * * *$ & $(0.2511)$ \\
\hline Change in price & $-1.6990 * * *$ & $(0.0857)$ & $-1.6990 * * *$ & $(0.0857)$ & $-1.7097 * * *$ & $(0.0859)$ \\
\hline CAPEX/TA3Y & -0.2182 & $(0.9318)$ & -0.2189 & $(0.9328)$ & -0.1232 & $(0.9382)$ \\
\hline $\begin{array}{l}\text { Equity incentives } \\
\text { total }\end{array}$ & 0.0121 & $(0.0762)$ & & & & \\
\hline $\begin{array}{l}\text { Equity incentives } \\
\text { stock } \\
\text { Equity incentives } \\
\text { options }\end{array}$ & & & -0.0207 & $(0.0486)$ & $0.3033 * * *$ & $(0.0986)$ \\
\hline McFadden $R^{2}$ & 0.1309 & & 0.1309 & & 0.1324 & \\
\hline Nobs & 11961 & & 11961 & & 11961 & \\
\hline
\end{tabular}

We include the same financial control variables as in tables 3.6 and 3.7. Our results imply that we cannot reject our third hypothesis that SOX attenuates the demand for class-action lawsuits to discipline CEOs. Our interaction term for stock option incentives with a post-SOX dummy (that is, for 2002-2007) is negative and below the $10 \%$ significance but the pre-SOX variable for stock option incentives is 
positive and highly significant. In this analysis we also find support for our interpretation of class-action lawsuits as acting as a governance mechanism rather than a "bad performance event." We observe a changing relation in the slope between option incentives and the occurrence of shareholder litigation over time in addition to a change in the intercept, which is consistent with our interpretation of class-action lawsuits.

\section{Table 3.8: Equity Incentives Pre- and Post Sarbanes-Oxley}

In this table we perform the same regression as in Tables 6 and 7. Here we incorporate a dummy, which equals one if the observation lies in the post-Sarbanes-Oxley period (i.e. 2002 and later), and zero otherwise. We interact this variable with the level of equity incentives defined by our three measurements. The control variables are the same as in the analyses above. The Z-statistics are based on cluster robust covariances according to Huber/White. The models include year and industry fixed effects but coefficients are not reported for practical reasons. Statistical significance at the 10,5 , and $1 \%$ level is indicated by $* * *$, and $* * *$, respectively.

\begin{tabular}{|c|c|c|c|c|c|c|}
\hline \multicolumn{7}{|c|}{ Equity incentives predicted from all governance variables } \\
\hline & \multicolumn{2}{|c|}{ Probit: CA yes/no } & \multicolumn{2}{|c|}{ Probit: CA yes/no } & \multicolumn{2}{|c|}{ Probit: CA yes/no } \\
\hline & coefficient & S.E. & coefficient & S.E. & coefficient & S.E. \\
\hline intercept & $-3.2923 * * *$ & $(0.1753)$ & $-3.3388 * * *$ & $(0.1701)$ & $-3.0649 * * *$ & (0.1894) \\
\hline Accruals & -0.3042 & $(0.5834)$ & -0.3073 & $(0.5871)$ & -0.2452 & $(0.5853)$ \\
\hline Return on Assets & 0.0398 & $(0.3308)$ & 0.0626 & $(0.3352)$ & 0.0441 & $(0.3355)$ \\
\hline $\mathrm{LOG}(\mathrm{M} / \mathrm{B})$ & $0.1552 * *$ & $(0.0617)$ & $0.1537 * *$ & $(0.0622)$ & $0.1681 * * *$ & $(0.0623)$ \\
\hline LOG(TA) & $0.1736 * * *$ & $(0.0176)$ & $0.1720 * * *$ & $(0.0173)$ & $0.1673 * * *$ & $(0.0173)$ \\
\hline Cash Flow/TA & -0.3881 & $(0.4209)$ & -0.3906 & $(0.4238)$ & -0.3946 & $(0.4181)$ \\
\hline Dividend pay & $-0.1952 * * *$ & $(0.0612)$ & $-0.1808 * * *$ & $(0.0618)$ & $-0.1945 * * *$ & $(0.0615)$ \\
\hline Equity issue & $-0.1350 * *$ & $(0.0694)$ & $-0.1265^{*}$ & $(0.0695)$ & $-0.1274 *$ & $(0.0695)$ \\
\hline Change in sales & $0.0034 *$ & $(0.0021)$ & $0.0036^{*}$ & $(0.0021)$ & $0.0039 *$ & $(0.0021)$ \\
\hline Change in price & $-0.0101 * * *$ & $(0.0008)$ & $-0.0103 * * *$ & $(0.0008)$ & $-0.0103 * * *$ & $(0.0008)$ \\
\hline CAPEX/TA3Y & -0.8597 & $(0.6291)$ & -0.6660 & $(0.6267)$ & -0.5960 & $(0.6410)$ \\
\hline $\begin{array}{l}\text { Equity incentives } \\
\text { total }\end{array}$ & -0.0036 & $(0.0603)$ & & & & \\
\hline $\begin{array}{l}\text { Equity incentives } \\
\text { total*SOX }\end{array}$ & -0.0955 & $(0.0934)$ & & & & \\
\hline $\begin{array}{l}\text { Equity incentives } \\
\text { stock }\end{array}$ & & & 0.0080 & $(0.0395)$ & & \\
\hline $\begin{array}{l}\text { Equity incentives } \\
\text { stock*SOX }\end{array}$ & & & $-0.0869 * *$ & $(0.0430)$ & & \\
\hline $\begin{array}{l}\text { Equity incentives } \\
\text { options }\end{array}$ & & & & & $0.2413 * * *$ & $(0.0696)$ \\
\hline $\begin{array}{l}\text { Equity incentives } \\
\text { options*SOX }\end{array}$ & & & & & $-0.0773 *$ & $(0.0519)$ \\
\hline McFadden $R^{2}$ & 0.13 & & 0.14 & & 0.14 & \\
\hline Nobs & 119 & & 119 & & 119 & \\
\hline
\end{tabular}




\subsection{Are Lawsuits a Disciplining Device for "Excessive" Risk?}

Too many option incentives determined by governance structures trigger managerial risk-taking. Shareholders can counteract this behavior by suing the firm and thus bringing in a further disciplining governance mechanism. We ask the question about the consequences of "excessive" stock options in combination with giving CEOs the discretion to negotiate for incentives. We find that governance structures enable the level of stock option incentives to a significant extent. The consequence of this "excessive" component of stock options is that shareholders counter allegedly high levels of risk-taking with class-action lawsuits. For minority shareholders and private investors this is a central corporate governance mechanism, whose mere threat disciplines management ex ante. The necessity for this threat taking place diminishes after the introduction of SOX's increased personal liabilities for directors and officers and, therefore, provides a more cost-efficient alternative to filing lawsuits.

It seems imperative to study whether Sarbanes-Oxley is effective given the results of our analysis. We interpret our finding as an additional external disciplining mechanism for managers. Sections XIII, IX and XI impose higher penalties for financial fraud and insider trading committed by directors and officers. Before 2002 managers were still sued but were not held personally liable to the same extent as after 2002. Chhaochharia and Grinstein (2007) analyze the impact of the SOX introduction on companies that were subject to insider trading before. Stock market valuation responded favorably for these companies, but subsequent abnormal return performance was generally lower than the benchmark due to a decrease in inherent risk. If shareholders can hold CEOs liable to a higher extent for financial fraud and can demand parts of their personal wealth, then we find that CEOs' incentives for financial fraud (and to profit from option incentives) are weaker in the post-SOX period. This is simply because the mere threat of a class-action lawsuit and the accompanying potential severity for the manager is higher after 2002 and therefore poses an additional disciplining mechanism.

Based on our results, we can also question whether shareholders should actually care about CEOs' level of stock options and whether it makes a difference for them how the CEO is compensated. Our results indicate that as long as shareholders have the opportunity to counteract adverse CEO actions and these disciplining mechanisms are effective, they still have sufficient opportunities to take corrective action ex post. The more the CEO's wealth is dependent on the stock price, the more he will be "punished" ex post for misbehavior and risk taking. Our 
paper rejects the statement by Armour et al. (2009) that states that class-action lawsuits are ineffective.

In fact we argue the opposite by stating that the mere filing of a lawsuit hurts the equity-aligned CEO by depressing the stock price-irrespective of the legitimacy of the allegations and who eventually covers the settlement. We find that shareholders do take action at firms that have experienced highly volatile performance due to managerial risk-taking triggered by stock options and managerial discretion. In their empirical analysis of firms facing SEC enforcement subsequent to class-action lawsuits, Karpoff, Lee, and Martin (2008a) find that the consequences for managerial misconduct can be quite severe. Moreover, the authors find a remarkable result with respect to Sarbanes-Oxley's effect on personal penalties for managers. The authors find that in only $5 \%$ of the cases do SOX's provisions need to be invoked for a legal penalty, and conclude that "firms' internal governance [...] worked to penalize much financial misrepresentation even before the 2002 Sarbanes-Oxley Act" (Karpoff, Lee, and Martin 2008a, p. 214). The authors' argument boils down to saying that where managers "get caught" for financial misrepresentation, shareholders hardly have to make use of SOX's provisions. Our paper offers a different interpretation. In our view, the ex ante threat of increased personal liability already functions to make CEOs less manipulative and risk-seeking due to their option incentives. We stress that our sample rules out any conclusions on whether allegations are well-founded or whether managers of the firms have eventually been found guilty. We treat the mere occurrence as a threat from shareholders and as a countervailing governance mechanism.

The results of event studies also underpin the credibility and the effect of the filing of lawsuits by highlighting the stock price impact for the equity-aligned manager. Neither our paper nor Bauer and Braun (2010) have discriminated between ex post meritorious lawsuits and unfounded allegations, but deliberately include all filings. Class-action lawsuits are the shareholders' desire to discipline managers and to correct managerial failure. This is triggered by taking risks in the form of higher performance volatility. Hence, shareholders can punish the CEO ex post for possible shirking or manipulation.

CEOs indeed tend to select and design their own board, which sets compensation and incentive schemes. The corporate governance literature has already pointed at boards of directors as "endogenously determined institutions" (Hermalin and Weisbach, 2003; Shivdasani and Yermack, 1999). Directors and officers can take risks and increase the volatility of the firm's share price to either benefit from a value-increase in their option portfolio or to derive non-pecuniary benefits from "speculating and taking a view" (Géczy, Minton, and Schrand 2007, p. 2407). In their survey on corporations' use of derivatives for speculative purposes, 
the authors find distinctive characteristics for speculating firms versus nonspeculating ones. The authors document that compensation arrangements are significantly different for managers taking a view compared to CEOs speculating infrequently. Hence, CEOs and CFOs of speculating firms have an interest in increasing the volatility of the firm's share price if their level of equity-based incentives is high.

Considering class-action lawsuits to estimate managers' risk-taking propensity and potential for forensic malfeasance also bears further implications for the firm, namely consequences in terms of stock market valuation, expected returns, and financial distress. With increased firm risk, investors will ultimately discount the firm's future cash flows at a higher rate, which leads to a lower valuation in the medium- and long-term. Our results of executive compensation triggering classaction lawsuit adds to the findings of Gompers, Ishii, and Metrick (2003). In their paper, well governed companies are valued higher, perform better operationally, and invest more efficiently. Complementing this finding, it is fair to state that wellgoverned companies give less discretion for the CEO's incentive schemes, which reduces shareholder litigation risk.

Our paper does not take a view on whether class-action lawsuits should be used as a governance mechanism of last resort. Do excessive option incentives represent optimal contracting or is it a consequence of the rent-seeking behavior of CEOs? An answer to this question ultimately depends on how costly class-action lawsuits are on a macro level. The costs comprise the active monitoring costs for shareholders, direct costs of the filing and attorney fees, and eventually whether lawsuits result out of poor performance or as a correction of out-of-equilibrium incentives and governance failures. In the latter case we might consider it to be optimal contracting whereas the former situation points at CEOs' risk-seeking behavior.

\subsection{Conclusion}

We started with shareholders facing a trade-off in the granting of stock options to CEOs. Having too few options does not give the right incentives to exert optimal effort but having too many options gives incentives "to do bad" in the form of irresponsible project risks, timing information to the market, and eventually manipulating numbers to inflate stock prices. A further trade-off is involved in the question of who determines the incentives. Outside shareholders often lack the sophistication so incentives are determined by the insiders themselves. Corporate insiders are usually the most informed but they act with discretion. The cost is that they are able to exploit informational asymmetries to negotiate for excessive stock options. Ample empirical and anecdotal evidence shows that because of this 
exploitation, CEOs tend to engage in problematic behavior. Shareholders are too diffuse in order to coordinate on the CEO's pay package. The consequence is that institutional investors vote with management and shareholder proposals have increasing but lower success rates in absolute terms (Gillan and Starks, 2007). Our paper answers the question of the consequences of these excessive equity incentives by focusing on the stock option factor.

Class-action lawsuits are an available governance tool, which exerts a sufficiently credible threat to discipline managers to not behave adversely. The stock market reacts negatively around the event date depending on the nature of the allegations and the punishment is greater when more allegations are asserted. This way, the filing provides a credible threat for the equity-aligned manager ex ante. Our observation that shareholders monitor the CEO's excessive risk-taking behavior means that they counteract this behavior in the form of class-action lawsuits- the "sued" issue, which punishes CEOs ex post. Given that variable CEO compensation via options has been acknowledged to align managers with equity holders - the "glued" issue - our paper confirms that it potentially creates another problem. It increases managerial propensity to manage for short-term equity prices due to options' leverage and non-linearity in the payoff.

Will shareholders actually care given that they can counteract this behavior and can rely on Sarbanes-Oxley's personal liability threat as an additional mechanism? If the filing of a lawsuit is costless, excessive stock option incentives should not matter. The question on whether shareholders should actually care about the option incentives depends on the actual direct and indirect costs of lawsuits. Returning to restricted stock as a means of compensation could be an alternative mechanism given its negative effect on the likelihood of being sued. 


\section{Appendix A: Corporate Governance Variables from Risk-Metrics and Thomson Reuters}

Note: for a detailed description of the variables listed under the "RiskMetrics Governance" section, please refer to Appendix A of Gompers, Ishii, and Metrick (2003).

\begin{tabular}{|c|c|c|c|}
\hline \# & full name & Definition & source \\
\hline 1 & Delaware incorporation & dummy variable $1=y e s$ & RiskMetrics Governance \\
\hline 2 & Sum of committees & Total board committees & self-constructed \\
\hline 3 & corporate "incidents" & sum of 6,8, and 9 & self-constructed \\
\hline 4 & Diversity ratio & $\begin{array}{l}\text { Diverse board members relative } \\
\text { to board size }\end{array}$ & self-constructed \\
\hline 5 & board size & number of board members & $\begin{array}{l}\text { RiskMetrics board \& } \\
\text { committees }\end{array}$ \\
\hline 6 & litigation disclosed & dummy variable $1=y e s$ & $\begin{array}{l}\text { Risk Metrics board \& } \\
\text { committees }\end{array}$ \\
\hline 7 & $\begin{array}{l}\text { employee representatives on } \\
\text { board }\end{array}$ & dummy variable $1=$ yes & $\begin{array}{l}\text { Risk Metrics board \& } \\
\text { committees }\end{array}$ \\
\hline 8 & $\begin{array}{l}\text { real estate transactions } \\
\text { disclosed }\end{array}$ & dummy variable $1=y e s$ & $\begin{array}{l}\text { Risk Metrics board \& } \\
\text { committees }\end{array}$ \\
\hline 9 & $\begin{array}{l}\text { third party transactions } \\
\text { disclosed }\end{array}$ & dummy variable $1=y e s$ & $\begin{array}{l}\text { Risk Metrics board \& } \\
\text { committees }\end{array}$ \\
\hline 10 & $\%$ independent board members & percentage $0-1$ & $\begin{array}{l}\text { Risk Metrics board \& } \\
\text { committees }\end{array}$ \\
\hline 11 & $\begin{array}{l}\text { Combined chair/CEO (CEO } \\
\text { Duality) }\end{array}$ & dummy variable $1=y e s$ & $\begin{array}{l}\text { Risk Metrics board \& } \\
\text { committees }\end{array}$ \\
\hline 12 & lead director & dummy variable $1=$ yes & $\begin{array}{l}\text { Risk Metrics board \& } \\
\text { committees }\end{array}$ \\
\hline 13 & D\&O holdings of voting stock & percentage $0-1$ & RiskMetrics Directors \\
\hline 14 & classified board & dummy variable $1=y e s$ & RiskMetrics Governance \\
\hline 15 & $\begin{array}{l}\text { director indemnification } \\
\text { contracts }\end{array}$ & dummy variable $1=y e s$ & RiskMetrics Governance \\
\hline 16 & $\begin{array}{l}\text { Governance Index (Gompers } \\
\text { et. al) }\end{array}$ & number 0 - 24 & RiskMetrics Governance \\
\hline 17 & severance payments & dummy variable $1=y e s$ & RiskMetrics Governance \\
\hline 18 & Instit. Ownership & Percentage $0-1$ & ThomsonReuters $13 \mathrm{~F}$ \\
\hline 19 & $\begin{array}{l}\text { Firm age (CRSP first listing } \\
\text { date) }\end{array}$ & In Years & CRSP \\
\hline 20 & golden parachute disclosed & dummy variable $1=$ yes & RiskMetrics Governance \\
\hline
\end{tabular}




\section{Appendix B: Financial and Control Variables from COMPUSTAT and CRSP}

\begin{tabular}{|c|c|c|}
\hline name & full name & description and definition \\
\hline MB & $\begin{array}{l}\text { Market to book } \\
\text { ratio }\end{array}$ & $\begin{array}{l}\text { market-to-book ratio as the market value of the firm's equity (item } \\
25^{*} \text { item 199) at the end of the year plus the difference between the } \\
\text { book value of the firm's assets (item } 6 \text { ) and the book value of the } \\
\text { firm's equity (item } 60 \text { ) at the end of the year, divided by the book } \\
\text { value of the firm's assets (item } 6 \text { ) at the end of the year }\end{array}$ \\
\hline ROA & Return on assets & $\begin{array}{l}\text { operating income before depreciation (item 13) plus the decrease } \\
\text { in receivables (item 2), the decrease in inventory (item } 3 \text { ), the } \\
\text { increase in current liabilities (item } 72 \text { ), and the decrease in other } \\
\text { current assets (item } 68 \text { ), divided by the average of beginning- and } \\
\text { ending-year book value of total assets (item } 6 \text { ) }\end{array}$ \\
\hline ACCR & Total accruals & $\begin{array}{l}\text { The change in accounts receivable (item } 2 \text { ), plus the change in } \\
\text { inventories (item } 3 \text { ), plus the change in other current assets (item } \\
68 \text { ). From this we subtract the change in accounts payable (item } \\
\text { 70), plus the change in other current liabilities (item } 72 \text { ). After } \\
\text { subtracting depreciation (item 178) we scale by total assets }\end{array}$ \\
\hline LEV & leverage & $\begin{array}{l}\text { Short plus long term debt (items } 9 \text { and 34) scaled by total assets } \\
\text { (item 6) }\end{array}$ \\
\hline Cashdiv & cash dividends & $\begin{array}{l}\text { sum of preferred and ordinary cash dividends (item } 19 \text { and } 21 \text {, } \\
\text { respectively) }\end{array}$ \\
\hline DIV & dividend dummy & dummy equals 1 if variable "cashdiv" is larger than zero \\
\hline deltasales & $\begin{array}{l}\text { average trailing } 3 \text { year } \\
\text { sales growth }\end{array}$ & change in total sales (item 12) \\
\hline deltaSP & $\begin{array}{l}\text { average change in share } \\
\text { price }\end{array}$ & change in fiscal year end share price (item 199) \\
\hline deltacash & average change in cash & change in cash and short term investments (item 1) \\
\hline TA & $\begin{array}{l}\text { book value of total } \\
\text { assets }\end{array}$ & book value of balance sheet total assets (item 6) \\
\hline TS & total sales & book value of balance sheet total assets (item 12) \\
\hline Equity & Equity issue dummy & $\begin{array}{l}\text { equals } 1 \text { if the change in number of shares outstanding in the prior } \\
\text { year was larger than } 10 \%\end{array}$ \\
\hline CAPX3y & $\begin{array}{l}3 \text { year average capital } \\
\text { expenditures }\end{array}$ & average of capital expenditures over the last three years (item 128) \\
\hline Earn & earnings & earnings is measured as operating income after depreciation (75); \\
\hline $\mathrm{CF}$ & earnings - accruals & cash flow is earnings minus accruals, scaled by TA \\
\hline
\end{tabular}




\section{Chapter 4}

\section{Laddered IPOs: A Case of Ineffective Regulation? ${ }^{1}$}

We study the effect of regulation on financial markets using the case of mysterious disappearance of lawsuits for laddering in initial public offerings (IPO) in 2001. We argue that this sharp reduction, far from being the outcome of a successful regulatory sweep, in fact was due to the investment banks changing the form of the game and that laddering still goes on with the same characteristics, but largely unnoticed by the Courts. We first show that underpricing is instrumental for laddering to occur and that IPOs have ex post not been underpriced optimally for deterring litigation. The underwriter exploits the asset management arm of the financial conglomerate it belongs to in order to support the price after the IPO. If we compare laddered IPOs to a matched sample of other similar but non-laddered IPOs, we see that in laddered IPOs, the probability of the affiliated conglomerate to have a stake is significantly higher (up to twice as high). No similar behavior is detected in case of non-laddered IPOs. A direct implication of this underwriter involvement is the fact that the performance of the laddered IPO is higher than that of other IPOs. Laddered firms display a similar risk-adjusted aftermarket performance as the nonladdered sample. Laddering keeps the price artificially high so as to allow the insiders to trade by selling their shares after the IPO and the expiration of the lockup period without negatively affecting the stock price. Indeed, laddered IPOs display abnormal - compared to the other IPOs and with respect to the average life of the stock - trading activity by the insiders as the lockup periods expire. This higher market activity by the insiders is not accompanied by higher price impact. We then show that after 2001, when no lawsuits were any longer filed, this overall behavior still persists. We build a model to predict laddering out-of-sample and show that "hidden laddered" IPOs display significant higher insider trading activity and a higher stake of the conglomerate affiliated with the underwriter. This trading takes place at convenient trading conditions with low price impact.

\footnotetext{
${ }^{1}$ Large parts of this chapter are based on Bodnaruk, Braun, and Massa (2010)
} 


\subsection{Introduction}

What is the effect of regulation on financial markets? It is often argued that regulation rarely achieves its goal as the regulated subjects respond in a way that minimizes the effects of regulation. We study this topic by focusing on one specific case study: the decision in 2000 of the SEC to clamp down on stock market manipulation by enforcing Regulation $M$ that was largely dormant until then ${ }^{2}$. This led to an exogenous change in the degree of enforcement against the practice called "laddering". This form of price manipulation involves the investment bank artificially pushing the secondary market price at the IPO in order to please the issuer and secure a larger allotment. To achieve this, the underwriting investment bank allocates IPO shares to privileged investors conditional on these same investors ("ladderers", hereafter) agreeing/committing to purchase additional shares in the aftermarket at predetermined dates. This behavior is deceitful for the uninformed investors who are unaware of laddering if the price declines after the IPO.

The SEC enforcement implied that a total of 312 firms that went public in 1998-2000 as well as their underwriters were subsequently sued for "laddering". After this clampdown in which the SEC began to enforce Regulation M, only a handful of IPOs which went public in 2001 or afterwards were sued for laddering. This has been hailed as a successful intervention of regulatory authorities. In this paper, we argue the opposite. We will show that the action of the regulatory authorities far from preventing laddering from taking place did instead make investment banks change the form of the game and pursued laddering strategies through other means.

We will proceed in two steps. First, we identify the drivers of laddering and relate them to stock underpricing. In particular, we show that laddering is implemented by the investment banks to help the pre-IPO insiders of the firm. Then, we use these determinants in the period when laddering has apparently disappeared to explain underpricing as a function of the very same determinants. We argue that this provides indirect evidence that alternative ways have been indentified to reach the same results that are less likely to originate lawsuits.

In order to identify the drivers of laddering, we start by relating the first day stock return (underpricing) to laddering. If underpricing is instrumental for investment banks to achieve their goals, this would induce a positive correlation between laddering and underpricing. And indeed, using an instrumental variable

\footnotetext{
${ }^{2}$ Section 101 of Regulation M under the Securities and Exchange Act of 1934 has been amended in 1997 in order to specifically proscribe market manipulation in the form of laddering.

${ }^{3}$ The first laddering lawsuit was filed against VA Linux on 11 January 2001.
} 
specification to control for endogeneity (Lowry and Shu, 2002), we document that more underpriced IPOs were more likely to be sued for laddering. ${ }^{4}$

Next, we study how the underwriter can implement laddering. We argue that the underwriter can use the firepower of the asset management arm of the financial conglomerate it belongs to to support the price after the IPO. We therefore investigate the investment in the laddered IPO firms by the members of the financial conglomerate affiliated with the underwriter. We track the ownership in IPO firms by the underwriter from the quarter after the IPO up to one year after. We show that in laddered IPOs, the probability that asset managers affiliated with lead underwriters hold a stake in the IPO firms and the size of their position is significantly higher (up to about twice as high) compared to non-sued IPOs or firms facing litigation in the context of material misstatements and omissions in their IPO prospectuses (Section 11). This can be observed right after the IPO and for at least a year after and holds both univariately and multivariately. Overall, laddered IPOs enjoy a much stronger direct support by the affiliated conglomerate: the underwriter keeps a significant fraction of the shares outstanding within the affiliated financial conglomerate to stabilize the price and to create favorable trading conditions.

A direct implication of this underwriter involvement is the fact that even though the prices of laddered IPOs have been artificially propped up, laddered IPOs do not underperform other IPOs. Indeed, if we construct a portfolio of laddered IPO firms and compare its net of risk performance in calendar time to that of a portfolio of all non-sued IPOs or a portfolio of similar non-sued IPOs we do not observe either economic or statistical difference between them.

We then look at the potential beneficiaries of the laddering strategy and we identify them in the insiders of the issuing firms. We argue and show that laddering keeps the price artificially high so as to allow the insiders to trade by selling their shares after the IPO and both before and the expiration of the lock-up period without negatively affecting the stock price. We document that this allows the insiders in laddered IPOs to reduce their ownership in the company prior to lock-up period expiration with little price impact. In particular, we show that insiders of laddered firms sell their shares significantly more often than insiders in non-sued firms. This holds whether we compare laddered firms to all non-sued firms or to a subsample of non-sued firms with similar characteristics. We consider dollar trading volume and

\footnotetext{
${ }^{4}$ Laddering is not limited to "hot" IPOs, it also extends to "cold" IPOs. And indeed, Griffin, Harris, and Topaloglu (2007) show that a reputable underwriter can also ladder cold IPOs with the threat of excluding the prospective investor from future offerings. Benefits are that the insiders of "cold IPO firms" can also sell at stabilized prices. A necessary condition for this to succeed is that the underwriter's IPOs have to be on average underpriced.
} 
the number of transactions executed. We include open market transactions as well as option exercises.

The results clearly show that insiders in laddered IPOs sell their shares much more often than insiders in other IPO firms not only after the lock-up period expiation, but also within the lock-up period. While this does not require prior notice to the public, it requires underwriter's approval. ${ }^{5}$ In $38.33 \%$ of laddered IPOs insiders sell their shares prior to lock-period expiration. This is significantly more often than $32.79 \%$ in the case of Section 11 IPOs, $29.25 \%$ for the full sample of non-sued IPOs and $24.11 \%$ for similar non-sued IPOs. When we look at insiders selling activity over one month after the lock-up period expiration in $37.63 \%$ of laddered IPOs insiders sell some of their shares. This should be compared to $27.87 \%, 20.57 \%$ and $25.53 \%$ for Section 11 , all non-sued and similar non-sued IPOs respectively.

This higher trading activity by the insiders is not accompanied by higher price impact. If we consider the stock price reaction to the sales of the insiders, we see that the stock price reaction around insider sales is similar for laddered IPOs and for other IPO groups. This result is robust to whether we consider insider sales done at any point in time or only sales executed prior to lock-period expiration. This evidence suggests that laddering is a way of providing price support to the insiders that lasts for the length of the lock-up period and beyond that and allows them to sell with minimal market impact.

Overall, these findings provide a rationale for laddering and relate it to underpricing. Then, we use our findings to test whether after 2001 laddering has completely disappeared - as the number of lawsuits would suggest - or whether it just changed shape. We therefore use the characteristics that identify the laddered IPO in sample till 2001 and build a model that predicts laddering. We then apply this model out-of-sample after 2001. In particular, we focus on the firms that have been identified as "laddered" and we determine whether they display the same characteristics that distinguished laddered firms. The results are striking: "predicted laddered" IPOs display significantly higher insider trading activity and a higher stake of the conglomerate affiliated with the underwriter. The magnitude of the effect is comparable to the actual laddered IPOs.

Moreover, "hiddenly-laddered IPOs" are characterized by the same selling activity of the insiders before and after the expiration of the lock-up period. As well

\footnotetext{
${ }^{5}$ An example of this can be found in eBay (Ticker symbol: EBAY. IPO date: 24 September 1998) Inc. IPO prospectus "The representatives of the several underwriters acting together may, in their sole discretion and at any time without notice, release all or any portion of the securities subject to lock-up agreements."
} 
as for the openly laddered IPOs of the previous decade, this trading takes place at convenient - in the sense of low price impact - trading conditions. This provides some suggestive evidence of the fact that, even if lawsuits have stopped, a phenomenon very similar to laddering is still taking place. We interpret it as suggesting that the regulatory changes just made it more difficult for investors to detect malpractices and to eventually file lawsuits.

Our results link to three main strands of the literature. The first deals with IPOs. We study a particular class of IPOs - the laddered ones. They have specific characteristics that differentiate them from other IPOs - higher underpricing, higher price support from the conglomerate affiliated with underwriter through a direct stake and higher insider trading, but comparable performance and price impact of insider trading.

Our results directly relate to the strand of IPO literature arguing that underpricing of IPOs could be seen as a way of buying litigation protection (Lowry and Shu, 2002). When we consider IPOs sued for material misstatement and omissions in the IPO prospectus according to Section 11 of the Securities and Exchange Act ("Section 11 IPOs") we confirm earlier findings by Lowry and Shu (2002) that these IPOs - unlike laddered IPOs - are underpriced optimally, i.e. that magnitude of underpricing is not related to the likelihood of litigation. In the case of laddering, the ex-ante likelihood of being sued for stock price manipulation was lower than ex-post likelihood. Indeed, even though Regulation $M$ has been in place since 1934 and was amended in 1997 to specifically address the practice of laddering, there were only a handful of IPOs sued for it prior to 2000 even though anecdotal evidence suggests that this practice has been widespread for a number of years prior to that. ${ }^{6}$ That resulted in a positive relation between underpricing and litigation for laddered IPOs.

Second, we contribute to the literature on financial conglomerates. Ritter and Zhang (2007) show that lead underwriters allocate hot IPOs to affiliated funds, and Ellis, Michaely, and O'Hara (2000) show that NASDAQ market makers belonging to a financial group support the stock price of the firms whose IPOs have been underwritten by an investment bank belonging to the same group. Acharya and Johnson (2007), and Ivashina and Sun (2010) provide evidence of bank insider trading by showing that lending banks use private information regarding corporate

\footnotetext{
${ }^{6}$ Our database on securities litigation suggests three lawsuits which were filed prior to 2001: on 22 July 1996, 11 April 1997, and 21 August 1998. Documents in Re: Initial Public Offerings Securities Litigation suggest that market manipulation and tie-in agreements (i.e. "laddering") are not a new phenomenon: hot issue periods between 1959 and 1963, 1967-1971, 1979-1983 have also witnessed practices of tie-in agreements (See Report of the Securities and Exchange Commission concerning the hot issues markets, at 4-28, Aug. 1984). For further details please refer to:

http://news.findlaw.com/hdocs/docs/ipo/ipolit21903opn.pdf
} 
clients to trade credit default swaps or equity. Massa and Rehman (2005) show that mutual funds use the inside information available to the affiliated banks lending to firms around the time the loan is granted. We provide indirect evidence of coordinated behavior of financial conglomerates in the case of IPOs.

Third, we contribute to the debate on the effects of regulation. Our results show that the change in regulation almost completely eliminated the lawsuits, without eliminating the behavior behind them. This has important normative implications as it seems to suggest that the regulatory changes far from protecting the shareholders in fact allowed investment banks and firms to stave off lawsuits. This qualifies as evidence of "captive regulation".

The remainder of the paper is organized as follows. In Section 2, we describe the data and the construction of the main variables. In Section 3, we provide evidence of the relation between laddering and underpricing. In Sections 4 and 5, we relate laddering to the investment banks' behavior and to the insiders' behavior respectively. In Section 6, we look out of sample and we study how laddering persisted even in the absence of lawsuits. A brief conclusion follows.

\subsection{Data}

\subsubsection{Data Sources}

We focus on NASDAQ IPOs done between 1995 and 2007. The choice of our sample period is motivated by the availability of lawsuit data. We deliberately choose to focus on NASDAQ IPOs for several reasons. First, this provides us with a relatively homogenous sample of firms going public: high growth opportunities, short balance sheet history and low asset tangibility. Second, investors trading in NASDAQ stocks represent a particular group of risk-seeking clientele. Third, according to Ellis, et al. (2000) only on NASDAQ the underwriting investment bank also has the opportunity to become the active market maker for the aftermarket trading. In fact, Ellis et al. (2000) argue that the lead underwriter of NASDAQ IPOs always becomes the market-maker, the most active dealer and a significant provider of post-IPO liquidity.

In order to identify IPO firms as being laddered or not we rely on two online databases. The Securities Class Action Clearinghouse from Stanford Law School lists the name, filing date and nature of allegations towards the firm and if applicable the names of the involved investment banks. ${ }^{7}$ We cross-check and verify this with information from the website of IPOSecuritiesLitigation.com. Between

\footnotetext{
${ }^{7}$ Available online via http://securities.stanford.edu
} 
1995 and 2007 we identify 292 NASDAQ IPOs where the investment bank(s) have been sued for manipulative underwriting and/or allocation practices.

Additionally, we identify IPO firms which have been sued for false and misleading statements or a failure to disclose material information in the public offering prospectus (sued under Section 11). This is a kind of lawsuits studied by Lowry and Shu (2002) over 1988 to 1995 time period. We were able to identify 61 of such firms during our sample period.

Data on IPO firms is obtained from SDC Global New Issues Database. We exclude closed end funds, unit offerings, REITs, financial firms, reverse LBOs and spin-offs. In order to be included in our database, firms need to have sufficient information on initial return. Firm age and underwriter reputation rankings have been obtained from the website of Jay Ritter (http://bear.cba.ufl.edu/ritter/) whereas accounting and performance variables come from CRSP/COMPUSTAT merged database. Missing pieces of information on lock-up length have been hand-collected. A complete description of our variables can be found in Appendix A and B. Our total sample comprises 2,469 firms with 2,320 firms having complete data.

For our analysis on post IPO insider selling behavior we rely on Thomson Reuters Insider Transactions database. We focus only on open market purchases and disposals (Thomson Reuters Transaction codes "P" and "S") of derivative and nonderivative securities by insiders with cleanse indicators of " $R$ ", " $H$ ", or " $C$ " in order to obtain a reasonable level of accuracy. ${ }^{8}$ Moreover, we group insiders into level 1 and level 2 insiders according to the classification of Thomson Reuters. The classification of Level 1 insiders is in line with the definition of Cicero (2009). These two groups might have potentially different access to inside information, which is why we decide to contrast these two groups.

We also require sufficient information on the length and time of expiration of the lock-up period. Since SDC data is insufficient for this item for more than $20 \%$ of our sample, we hand-collect missing information from individual firm prospectuses from SEC Edgar. Our filtering process of insider transaction data closely follows the method as in Bebchuk, Grinstein, and Peyer (2010).

We identify equity ownership by underwriting investment banks by aggregating positions of their asset management affiliates from Spectrum 13F. Given that different divisions of a financial conglomerate (banks, insurance firms, mutual fund families, etc.) often appear in $13 \mathrm{~F}$ filings as separate entities lacking

\footnotetext{
${ }^{8}$ The Cleanse Indicator indicates Thomson's level of confidence concerning the accuracy of a particular record contained in the database
} 
common identifiers, we constructed a database that groups the different divisions of individual financial groups under single umbrellas. This database has been assembled manually from various public sources. ${ }^{9}$ For a more detailed description of conglomerate construction and the descriptive statistics of conglomerates' characteristics see the description of a "brand" construction in Bodnaruk, Massa, and Simonov (2009).

\subsubsection{Descriptive Statistics of Laddered IPOs}

We start with some univariate statistics. We track the distribution of sued firms across years and industries and discriminate between IPOs sued for material misstatements and omissions (Section 11 IPOs) and laddered IPOs. The results are shown in Table 4.1. Two noteworthy patterns emerge from Panel A. First, laddered IPOs clearly peak during the tech bubble between 1998 and 2000 and almost completely disappear thereafter. By contrast, Section 11 IPOs are more evenly distributed over our sample period. Second, the general IPO activity declines after 2000 reflecting the cold issue period after the burst of the internet bubble. Panel B shows distribution of IPOs and IPO litigation activity across industries. "Science", "Manufacturing" and "Communication, Computers \& Electronics" stand out in terms of number of IPOs, the latter also being the one with most instances of litigation. Overall, we observe that $14.30 \%$ of 2,469 IPOs between 1995 and 2007 have been sued for either laddering or for material misstatements and omissions under Section 11 . This value is significantly higher than the $8 \%$ litigation frequency reported by Lowry and Shu (2002).

We present descriptive statistics of offering and aftermarket characteristics for IPO firms in Table 4.2. Laddered IPOs have much larger first day returns and are much likely to have their offer price updated than both non-sued IPOs and Section 11 IPOs. They are also larger and have lower leverage, but raise similar proceeds to Section 11-sued IPOs. Laddered IPOs are younger firms, underwritten by more reputable investment banks, more likely to be venture capital backed and to be high tech firms. They also have larger post-IPO volume and turnover. The average laddered firm has negative earnings (strongly negative PE ratio) and a poor operating margin. This provides some indication and outlook on how these firms might perform in the aftermarket and why laddering might be in the issuer's interest.

\footnotetext{
${ }^{9}$ We used the directory of investment advisers maintained by the SEC (www.adviserinfo.sec.gov), Morningstar's directory of mutual fund family websites (www.advisor.morningstar.com), and the websites of financial groups and mutual fund families. All affiliations, transaction dates, and missing information were double-checked using extensive web querying.
} 


\subsection{Laddering and Underpricing}

\subsubsection{Methodology}

We now examine the relation between litigation risk and IPO underpricing. We distinguish between two types of lawsuits - laddering and Section 11. We expect that firms that ex-ante correctly anticipate their likelihood of being sued for a particular type of violations would chose to underprice shares optimally - i.e. the magnitude of underpricing would not affect the probability of litigation. At the same time, if the likelihood of being sued for a particular violation is underestimated and underpricing is beneficial to the company insiders and investment banks, this would ascertain a positive relation between underpricing and litigation.

Our task is not simple as firms choose underpricing in such a way as to minimize the likelihood of being sued and the decision by shareholders to file a suit is dependent on the observed underpricing. We thus face a problem of joint estimation of underpricing and litigation.

\section{Table 4.1: Distribution of sample firms across years and industries}

The sample consists of completed IPOs between 1995 and 2007 that are in the Securities Data Company (SDC) database. Closed-end funds, unit offerings, REITs, financial firms, reverse LBOs, ADRs and spinoffs are excluded. Firms must also have data on initial returns. The final sample consists of 2,469 firms. Sued firms represent those IPOs that are listed in the Shareholder litigation database from Cornerstone Research (http://securities.stanford.edu) and IPO Securities Legislation (www.iposecuritieslitigation.com). Panel A classifies the total number of IPOs and the number of IPOs that were sued by year. Panel B classifies the firms by industries (where industries are by SIC code).

\begin{tabular}{lcccc}
\hline \hline $\begin{array}{c}\text { Panel } A: \\
\text { by Year }\end{array}$ & $\begin{array}{c}\text { No } \\
\text { of IPOs }\end{array}$ & \% sued “laddering” & $\begin{array}{c}\text { \% sued } \\
\text { LS-type }\end{array}$ & $\begin{array}{c}\text { \% sued } \\
\text { (pooled) }\end{array}$ \\
\hline 1995 & 298 & $0.34 \%$ & $2.01 \%$ & $2.35 \%$ \\
1996 & 486 & $0.41 \%$ & $2.47 \%$ & $2.88 \%$ \\
1997 & 309 & $0.00 \%$ & $2.27 \%$ & $2.27 \%$ \\
1998 & 165 & $4.24 \%$ & $3.64 \%$ & $7.88 \%$ \\
1999 & 407 & $41.77 \%$ & $0.25 \%$ & $42.01 \%$ \\
2000 & 334 & $32.93 \%$ & $1.80 \%$ & $34.73 \%$ \\
2001 & 46 & $0.00 \%$ & $4.35 \%$ & $6.52 \%$ \\
2002 & 38 & $0.00 \%$ & $7.89 \%$ & $7.89 \%$ \\
2003 & 35 & $0.00 \%$ & $5.71 \%$ & $5.71 \%$ \\
2004 & 107 & $0.00 \%$ & $3.74 \%$ & $3.74 \%$ \\
2005 & 87 & $1.15 \%$ & $2.30 \%$ & $3.45 \%$ \\
2006 & 103 & $0.97 \%$ & $4.85 \%$ & $5.83 \%$ \\
2007 & 53 & $0.00 \%$ & $7.55 \%$ & $7.55 \%$ \\
\hline \hline
\end{tabular}




\begin{tabular}{|c|c|c|c|c|c|}
\hline $\begin{array}{l}\text { Panel B: } \\
\text { By Industry }\end{array}$ & SIC Codes & $\begin{array}{l}\text { Total } \\
\text { \# of } \\
\text { IPOs }\end{array}$ & $\begin{array}{l}\text { \# of IPOs } \\
\text { sued }\end{array}$ & $\begin{array}{c}\text { \# of } \\
\text { Section } \\
11 \text { IPOs }\end{array}$ & $\begin{array}{c}\# \text { of } \\
\text { Laddered } \\
\text { IPOs }\end{array}$ \\
\hline Agriculture and Mining & $100-1299,1400-1499$ & 7 & 0 & 0 & 0 \\
\hline Apparel & $2200-2399,3100-3199$ & 13 & 1 & 1 & 0 \\
\hline $\begin{array}{l}\text { Communications, } \\
\text { Computers and } \\
\text { Electronics }\end{array}$ & $3570-3570,3600-3699$ & 1139 & 256 & 28 & 228 \\
\hline Construction & $1500-1799$ & 12 & 1 & 0 & 1 \\
\hline Finance & $6000-6499,6700-6799$ & 6 & 0 & 0 & 0 \\
\hline Food & $2000-2099$ & 20 & 0 & 0 & 0 \\
\hline Health & $\begin{array}{l}8000-8099 \\
2400-2499,2600-2699,2800-\end{array}$ & 60 & 3 & 3 & 0 \\
\hline Manufacturing & $\begin{array}{l}2899,3000-3099,3200-3569 \\
3580-3599,3900-3999\end{array}$ & 268 & 12 & 7 & 5 \\
\hline Oil and Gas & $\begin{array}{l}1300-1399,2900-2999,4600- \\
4699,4920-4929\end{array}$ & 51 & 3 & 3 & 0 \\
\hline Printing and Publishing & $2700-2799$ & 13 & 0 & 0 & 0 \\
\hline Recreation & $7000-7099,7800-7999$ & 40 & 6 & 3 & 3 \\
\hline Science & $\begin{array}{l}3800-3899,8710-8719,8730- \\
8739\end{array}$ & 262 & 15 & 3 & 12 \\
\hline Services & $\begin{array}{l}6500-6599,7200-7369,7380- \\
7399,7600-7699,8100-8399 \\
8720-8729,8740-8749\end{array}$ & 242 & 30 & 5 & 25 \\
\hline Trade & $5000-5999$ & 229 & 20 & 6 & 14 \\
\hline Transportation & $\begin{array}{l}3700-3799,4000-4299,4400- \\
4599,4700-4799,7510-7549\end{array}$ & 83 & 4 & 2 & 2 \\
\hline Utilities & $4910-4919,4930-4979$ & 10 & 0 & 0 & 0 \\
\hline Other & & 14 & 2 & 0 & 2 \\
\hline Total & & 2469 & 353 & 61 & 292 \\
\hline
\end{tabular}

We proceed with adopting a similar approach as in Lowry and Shu (2002) by assuming that both IPO underpricing and litigation risk are endogenously and simultaneously determined in a system of equations. In particular, if IPOs which are ex-ante more likely to be sued will be underpriced more, the degree of the underpricing is endogenous to the likelihood of litigation. Properly controlling for this endogeneity should eliminate the relation between underpricing and likelihood of litigation. We measure underpricing with the percentage difference of the offer price and the closing price on the first day of trading - the first day return. 


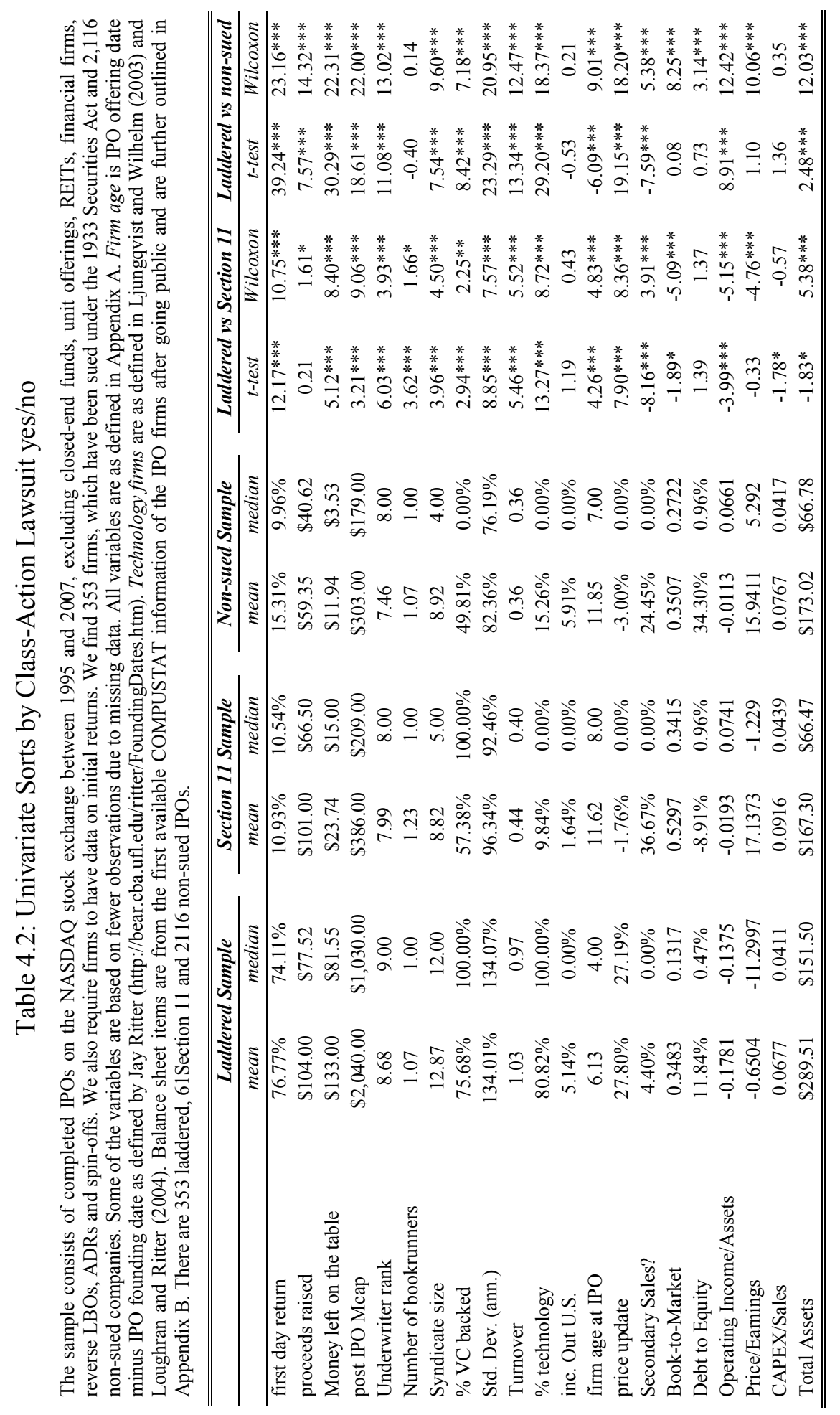


This ideal case would, however, require that the ex-ante likelihood of litigation is correctly estimated. In the case of laddering, the ex-ante likelihood of being sued for stock price manipulation was lower than ex-post likelihood. Indeed, even though Regulation M was in place since 1934 and was amended in 1997 to specifically address the practice of laddering, there were only a handful of IPOs sued for it prior to 2000 even though anecdotal evidence suggests that this practice has been widespread for a number of years prior to that. Therefore, if larger underpricing was instrumental for investment banks to achieve their goals (at the expense of investors) and if investment banks underestimated the threat of litigation for laddering, then they should have underpriced their IPOs excessively as this would have allowed them to benefit from price manipulation most. This would induce a positive correlation between laddering and underpricing.

Since we distinguish between laddering and Section 11 lawsuits we end up with the system of three equations, which we will outline below.

Insurance effect:

underpricing $=\gamma_{1 A}$ laddering litigation risk $+\gamma_{1 B}$ Section 11 Litigation Risk $+\theta_{1} X+\beta_{1} X_{1}+\varepsilon_{1}$

\section{Laddering litigation deterrence:}

Laddering Litigation Risk $=\gamma_{2}$ underpricing $+\theta_{2} X+\beta_{2} X_{2}+\varepsilon_{2}$

\section{Section 11 litigation deterrence}

Section 11 Litigation Risk $=\gamma_{3}$ underpricing $+\theta_{3} X_{3}+\varepsilon_{3}$

Maddala (1983, p.244-245) shows that a system of two equations using a continuous variable in the first stage and a dichotomous variable in the second stage is problematic as the parameters in the second equation cannot be fully recovered. To address this issue, in a two-stage probit model, the specification should be:

Underpricing $=\gamma_{1} \sigma_{2}$ litigation risk $^{* *}+\theta_{1} X+\beta_{1} X_{1}+\varepsilon_{1}$

litigation risk ${ }^{* *}=\frac{\gamma_{1}}{\sigma_{2}}$ underpricing $+\frac{\theta_{1}}{X_{1}} X+\frac{\beta_{2}}{\sigma_{2}} X_{2}+\frac{\varepsilon_{2}}{\sigma_{2}}$,

where $\sigma_{2}^{2}=\operatorname{Var}\left(\varepsilon_{2}\right)$. In our case, we face a system of three equations. Since laddering litigation neither directly affects Section 11 litigation nor vice versa, this boils down to:

Underpricing $=\gamma_{1 A} \sigma_{2}$ laddering lawsuit ${ }^{* *}+\gamma_{1 B} \sigma_{3}$ Section 11 Lawsuit $^{* *}+\theta_{1} X+\beta_{1} X_{1}+\varepsilon_{1}$ (6) 
Laddering Lawsuit ${ }^{* *}=\frac{\gamma 2}{\sigma_{2}}$ underpricing $+\frac{\theta_{2}}{\sigma_{2}} X+\frac{\beta_{2}}{\sigma_{2}} X_{2}+\frac{\varepsilon_{2}}{\sigma_{2}}$

Section 11 Lawsuit $^{* *}=\frac{\gamma_{3}}{\sigma_{3}}$ underpricing $+\frac{\theta_{3}}{\sigma_{3}} X+\frac{\beta_{3}}{\sigma_{3}} X_{3}+\frac{\varepsilon_{3}}{\sigma_{3}}$

The estimation consists of two stages. In the first stage, we regress underpricing, laddering risk and Section 11 risk on all the exogenous variables in the system including $\mathrm{X}_{1}, \mathrm{X}_{2}$ and $\mathrm{X}_{3}$ using OLS and probit, respectively. In the second stage, we substitute the predicted values from the first stage estimation for corresponding variables in regressions (6) - (8) and then estimate them with OLS and probit. Even though we cannot separately estimate $\gamma_{1 \mathrm{~A}}, \gamma_{1 \mathrm{~B}}, \gamma_{2}$ and $\gamma_{3}$ we can at least test whether these are statistically different from zero.

In the first stage regressions, the dependent variables are a laddering dummy (Section 11 dummy), which equals one if the firm was sued for laddering (material misstatements and omissions in the IPO prospectus) and zero otherwise, and underpricing, which is equal to the first day return relative to the IPO offer price.

In order to estimate our system of equations we need to identify predictive variables specific to each of our dependent variables. Thus, $\mathrm{X}_{1}$ has to have at least one variable which is not in $X_{2}$ and $X_{3}$. Similar logic should follow for $X_{2}$ and $X_{3}$. We use the following overidentifying restrictions. In equation (1) [underpricing], $X_{1}$ includes a dummy for venture capital (VC) backing and the size of underwriting syndicate. It is well known that general partners at VC firms are very sensitive to timely exits. ${ }^{1}$ Gompers and Lerner (1998) additionally suggest that underpricing is not a first order concern for VCs as venture capital funds rarely sell their shares at the IPO, but instead distribute shares to the limited partners in the fund at the postIPO market prices. Lin and Smith (1998) argue that VCs would like to establish a reputation for not selling overpriced shares and are willing to tolerate underpricing. All of this suggests that VCs are more likely to tolerate underpricing. Hence, VCbacking is a variable which conceptually explains underpricing, but is not related to the occurrence of litigation.

As a second variable which identifies underpricing, we include the logarithm of the size of the underwriting syndicate. Corwin and Schultz (2005) argue that larger syndicates lead to better information production which reduces information asymmetry in IPOs and sets a better offer price. At the same time there

\footnotetext{
${ }^{1}$ One reason being that they have to sell their shares (usually at the discount) in firms that did not get an exit at the time the fund was liquidated. In some cases they have to forgo their shares in such firms entirely (Kandel et al, 2010).
} 
does not seem to be any relation between syndicate size and either types of litigation.

To indentify equation (2) [laddering litigation risk], $\mathrm{X}_{2}$ includes stock turnover of matched firms. Since turnover is not measurable until after the IPO we use prior year share turnover. ${ }^{2}$ Turnover equals $\left[1-\prod_{t}\left(1-\right.\right.$ volume traded $_{t} /$ total shares $_{\mathrm{t}}$ )] over the one year prior to the IPO. The motivation behind this variable is as follows. The laddering practice by design generates significant trading due to investors meeting laddering "contracts" and high demand in the secondary market (Griffin, Harris, and Topaloglu, 2007). This will induce a positive correlation between turnover and laddering probability. Lowry and Shu (2002) used stock turnover as overidentifying restriction for Section 11 litigation. However, in our sample Section 11 litigation and share turnover appear to be unrelated.

To indentify equation (3) [Section 11 litigation risk], $\mathrm{X}_{3}$ includes the presence of insider sales (secondary sales) dummy. If company insiders do not reveal material information during pre-IPO process, this results in inflated IPO offer price. Insiders would then have incentives to sell (some of) their shares at such inflated price at the IPO (Grinblatt and Hwang, 1989). Secondary sales should therefore be positively related to the Section 11 lawsuit probability.

There are a number of control variables $(\mathrm{X})$ that are common to all three equations. We measure firm size with the market capitalization of the IPO on the first day of trading. Larger firms are more likely to get sued ("deep pockets hypothesis"). According to Michaely and Shaw (1994) larger issues are harder to sell and therefore should result in higher underpricing. We also include firm age (measured relative to the IPO firm's founding date) in all three regressions because there is less information asymmetry for mature firms, they are also easier to value, which results in less underpricing.

In the case of the estimation of the probability of laddering, we posit that underwriters pick to ladder opaque firms with high informational asymmetry. A similar line of reasoning (both for lawsuit probabilities and underpricing) applies for the IT dummy variable. Underwriter rank measures the reputation of the bookrunner(s) in the syndicate and is expected to provide certification to the issue and hence less underpricing. ${ }^{3}$ Reputable underwriters are also high quality repeat players in the IPO market. We also include the average standard deviation of the same matched sample of firms, which is an approximation for future stock price volatility.

\footnotetext{
${ }^{2}$ The matched sample consists of firms in the same three-digit SIC code with market capitalization within $80-120 \%$ of the IPO firm's market value at the close of the first day of trading.

${ }^{3}$ For the role of underwriter reputation and IPO underpricing over time, please refer to Loughran and Ritter (2004).
} 
High risk firms are more likely to be sued because higher volatility increases the probability of extreme losses.

Since our database spans 13 years of going public activity with different degrees of underpricing, we also include an indicator variable whether the IPO took place during the tech bubble years (i.e. between 1999 and 2000). Finally, Benveniste and Spindt (1989) and Hanley (1993) show that price update also tends to be related to underpricing. Moreover, a price update variable captures the "hotness" of the issue and this can affect laddering probability as well.

\subsubsection{Results without controlling for endogeneity}

We first report the results on the relation between underpricing and litigation risk without controlling for endogeneity. They are reported in Table 4.3. The first column tests the insurance effect: do firms with higher litigation risk purchase more insurance by underpricing more? We estimate an OLS regression of underpricing on laddering lawsuit dummy, Section 11 lawsuit dummy and control variables described above. The results suggest that there's a positive effect of laddering lawsuit litigation risk on underpricing, implying that firms with higher laddering lawsuit risk underprice their shares more. Consistent with Lowry and Shu (2002), we find that the relation between Section 11 litigation risk and underpricing is negative.

Columns two and three report on litigation deterrence effects. ME reports the marginal effects. The question is whether firms which choose higher levels of insurance (underprice more) reduce their likelihood of being sued. It appears that higher underpricing makes IPO firms more likely to be sued for laddering. This is inconsistent with a deterrence effect.

The effect of underpricing on Section 11 litigation likelihood is instead the opposite: companies buying more litigation protection are less likely to be sued for Section 11 violations. This is in line with deterrence effect and corroborates the findings of Lowry and Shu (2002). We are, however, hesitant to make any inferences from these results as our analysis could be potentially affected by the endogeneity bias. We now proceed to perform the simultaneous-system analysis which should take care of endogeneity concerns. 


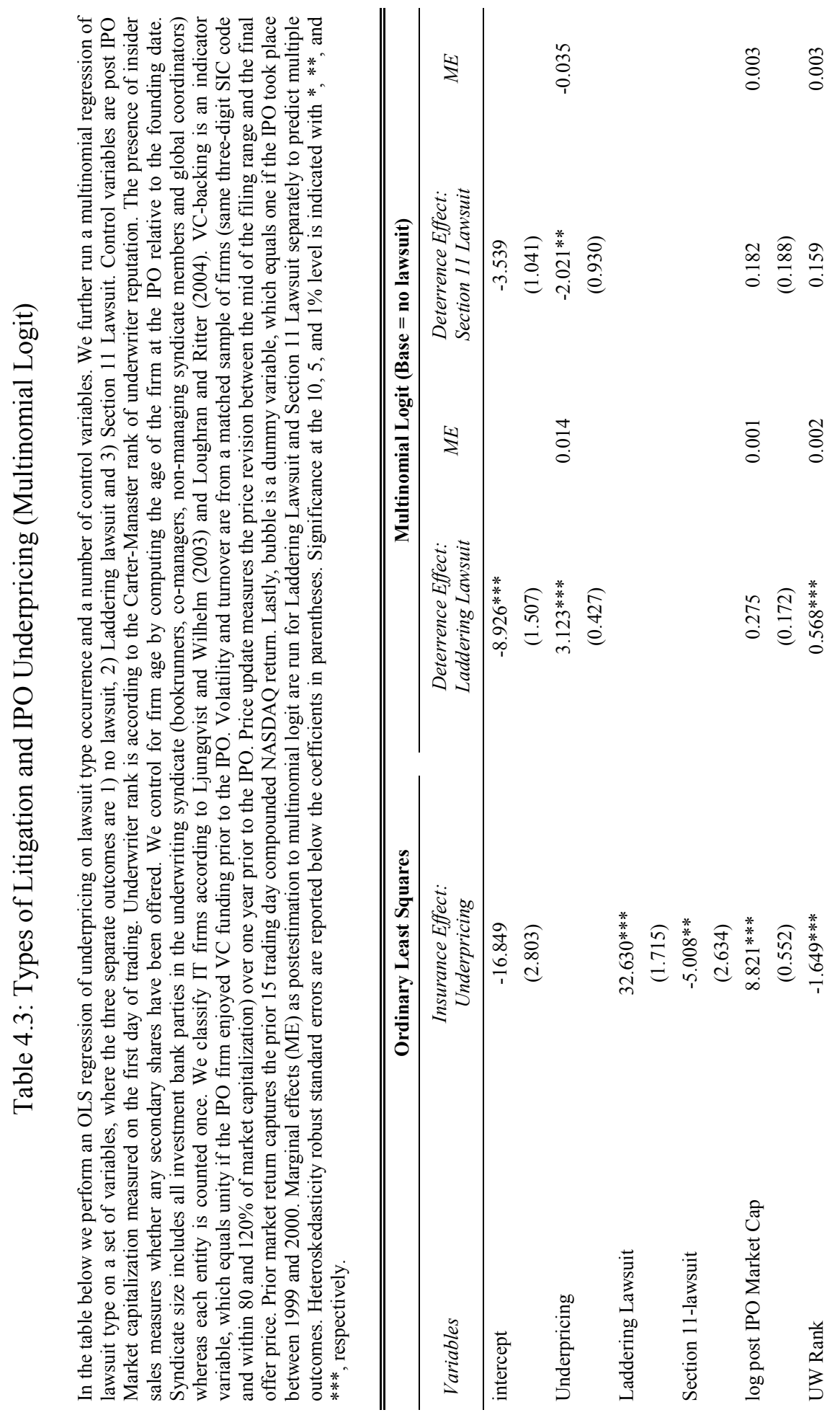




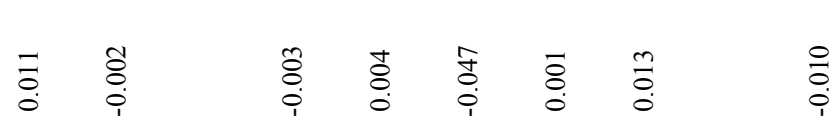

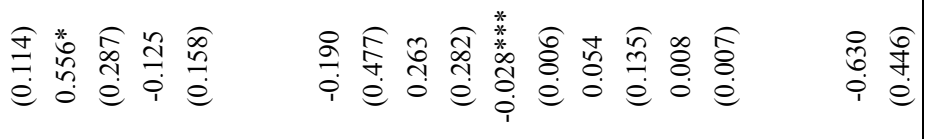

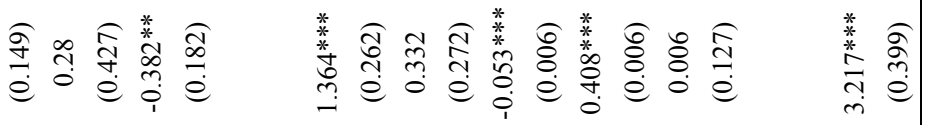

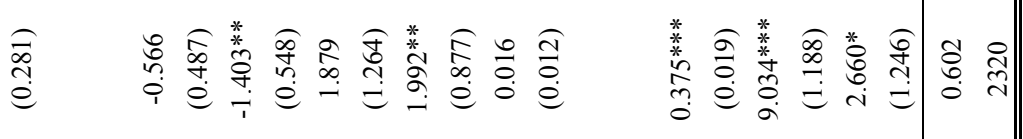

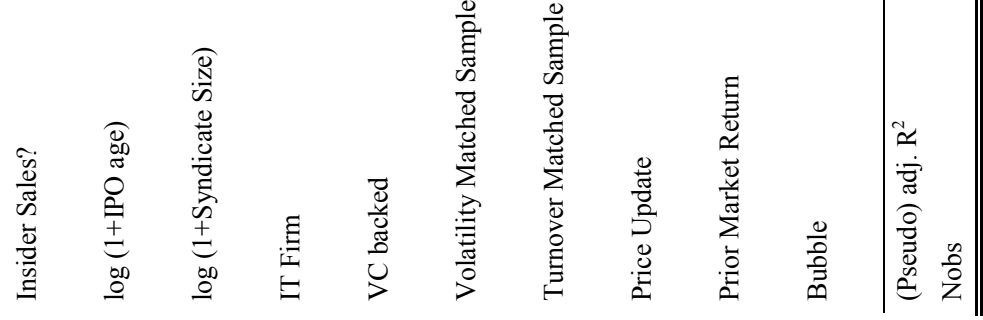




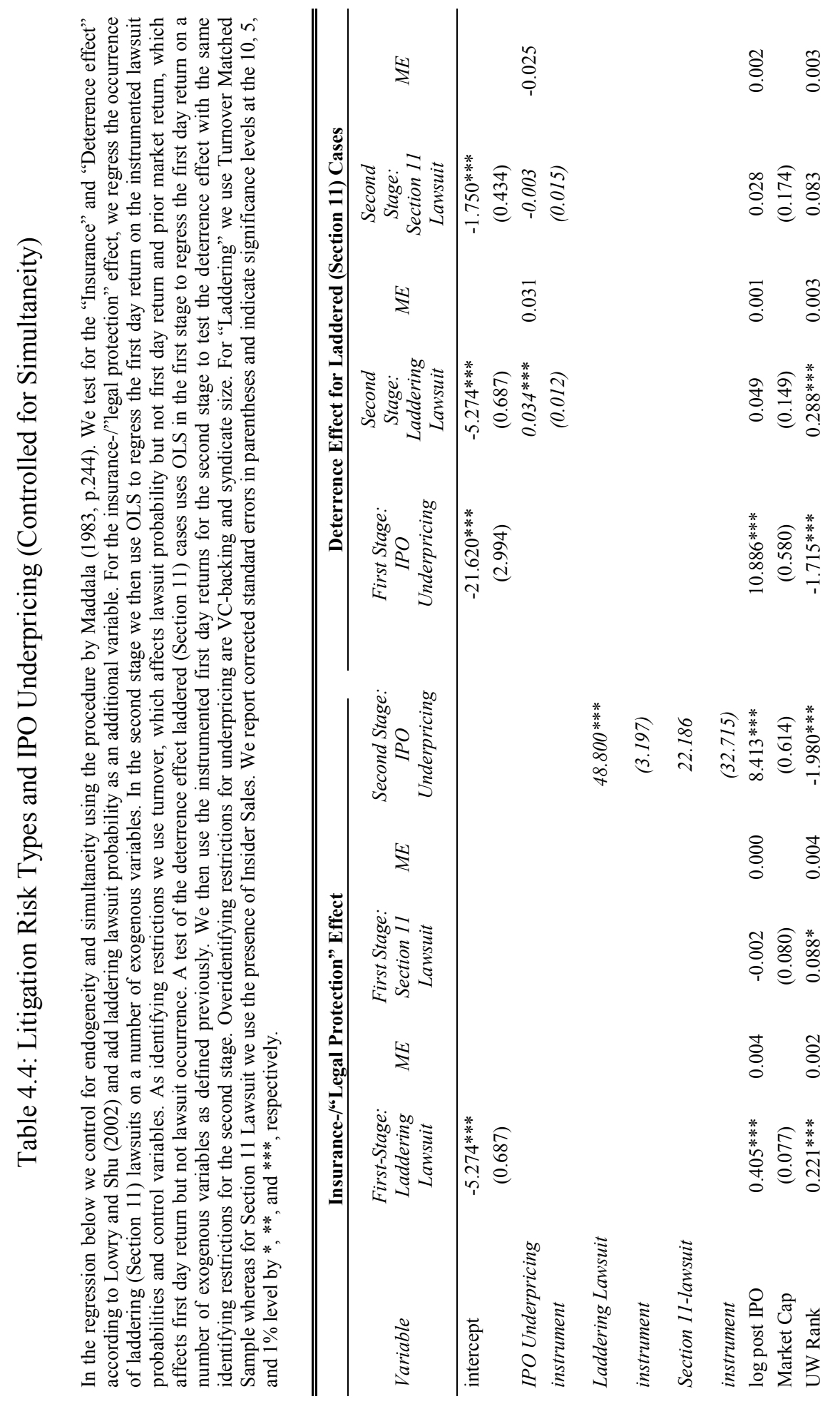




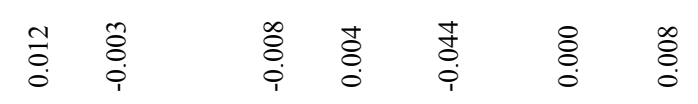

影|

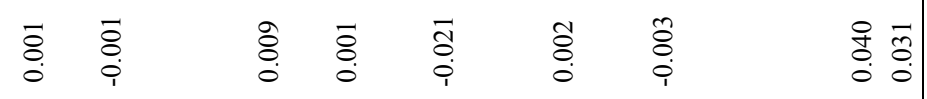

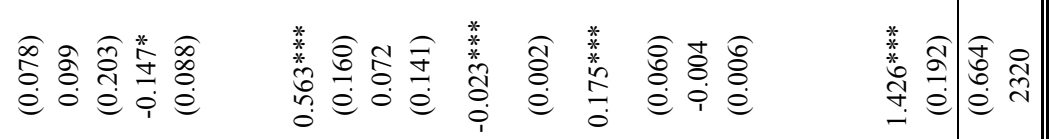

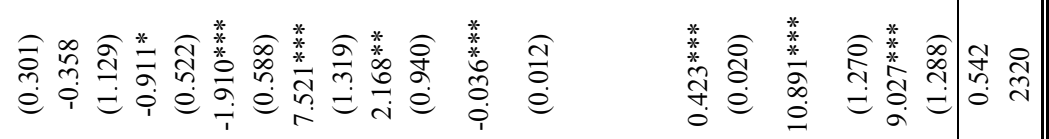

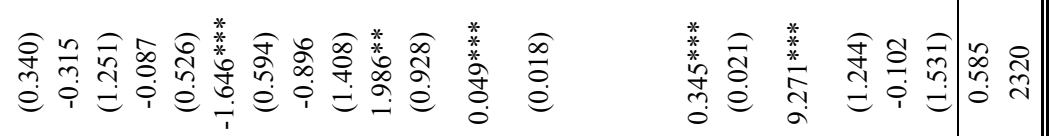

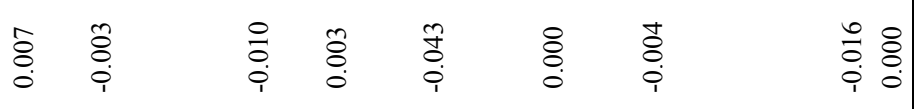

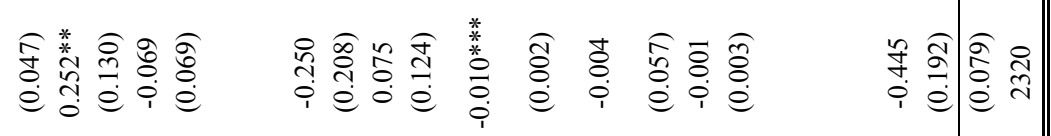

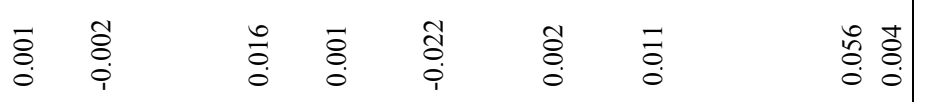

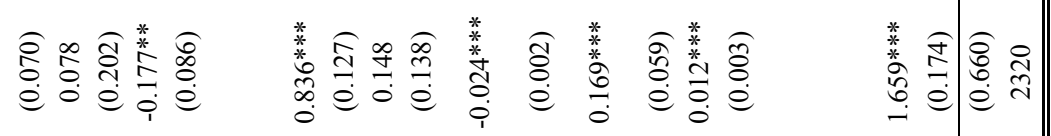

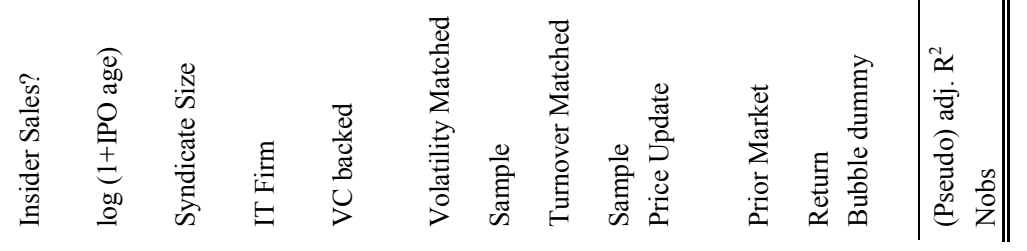




\subsubsection{Results after controlling for endogeneity}

To control for endogeneity of underpricing and litigation risk we reestimate equations (1)-(3) using the simultaneous-equation approach we described above. The results are reported in Table 4.4. Columns 1, 2, and 4 report the results of first-stage regressions where the dependent variables (underpricing, laddering litigation and Section 11 litigation) are regressed on all of our exogenous variables $\left(\mathrm{X}_{1}, \mathrm{X}_{2}, \mathrm{X}_{3}\right.$, and $\left.\mathrm{X}\right)$. Columns 3,5 , and 6 present the coefficients from second stage regressions from insurance and deterrence effects. The explanatory variables in the second stage are similar to those used in Table 4.3, with the exception that we now substitute the lawsuit and underpricing for their fitted values from first stage regressions. Inferences on the relation between litigation risk and underpricing are based on second stage regressions.

The results clearly show that in terms of the insurance effect, companies with higher likelihood of laddering lawsuit underprice their shares by a greater amount. The result is significant at the $1 \%$ level. Companies with higher likelihood of being sued for Section 11 violation are also more likely to underprice their shares; however, the effect is not significant.

When we turn our attention to litigation deterrence effect, we observe that IPO underpricing is not related to Section 11 litigation. The effect of underpricing on laddering litigation, however, is very different: companies which underprice their shares more are also more likely to be sued for laddering. The result is significant at $1 \%$ level and suggests that laddered IPOs were underpriced in excess to what was ex-post optimal from the litigation perspective.

\subsection{Laddering and Investment Bank Behavior}

The previous results show that laddering is related to a higher first day return. Laddering can be implemented by the financial conglomerate, which is affiliated with the underwriter by taking a direct stake in the IPO firm. We therefore, now investigate the investment in the laddered IPO firm of the members of the financial conglomerate affiliated with the underwriter. To do this, we study how performance of "laddered" firms compare to that of non-sued IPOs and to Section 11 IPOs and then we provide some evidence of investment bank's aggregate investment behavior in laddered IPOs. 


\subsubsection{Laddering and Stock Performance}

To analyze the performance of the IPO stocks, we refer back to the descriptive statistics reported in Table 4.2. They showed that laddered firms are significantly larger in total assets and significantly worse in operating performance. This suggests that we are facing two operationally and fundamentally different sets of firms. Effectively, this can result in self-selection with respect to the underwriting investment bank that the issuer might choose and the IPO (aftermarket-) pricing. To address this issue, we perform a matching sample estimation. We identify a group of non-sued IPOs, which are similar to laddered IPOs along a number of firm-specific characteristics. Matching on the basis of these variables therefore tackles potential concerns of endogeneity with respect to the likelihood of being laddered. We proceed as follows. We construct a propensity matched sample of non-sued IPOs based on the variables suggested by Hillion and Vermaelen (2004). These include total assets, operating income before depreciation/Assets, profit margin, return on assets, OIBD/Sales, CAPEX/Sales, and Market-to-Book ratio. We are able to identify matches to 258 (out of 292) laddered IPOs in our sample. We then test the difference in performance between laddered IPOs and the control group. We report the results of our matching procedure in Table 4.5. They show that our sample and control group are very similar along the matching characteristics.

We investigate long-term stock performance of IPO firms by constructing calendar time portfolios (Fama, 1998). At the beginning of the month following the IPO, we add the firm to the corresponding portfolio. We consider five portfolios: all IPOs, laddered IPOs, Section 11 IPOs, full subsample of non-sued IPOs and subsample of non-sued IPOs propensity matched to laddered IPOs. We consider five different holding periods: $6,12,24$, and 36 , and 48 months. To ensure that performance is corrected for risk we regress excess returns on these portfolios on Fama-French factors augmented by Carhart (1997) momentum factor. Results are reported in Table 4.6. The results show that laddered IPOs perform relatively well compared to other IPO groups. They consistently outperform Section-11 IPOs. The difference in monthly abnormal returns is 419 basis points (bp), $242 \mathrm{bp}$, and $298 \mathrm{bp}$, for 12, 24 and 36 month holding periods for equally weighted portfolios (corresponding outperformance is $396 \mathrm{bp}, 310 \mathrm{bp}$, and $197 \mathrm{bp}$ for value-weighted portfolios) and is significant at least at $5 \%$ level. Additionally, performance of laddered IPOs is statistically indistinguishable from that of non-sued IPOs. This holds when we compare laddered IPOs to a full sample of non-sued IPOs or to a subsample of matched non-sued IPOs and is consistent across investment horizons and observation weighting. This might be evidence of price support via laddering for the insiders. 


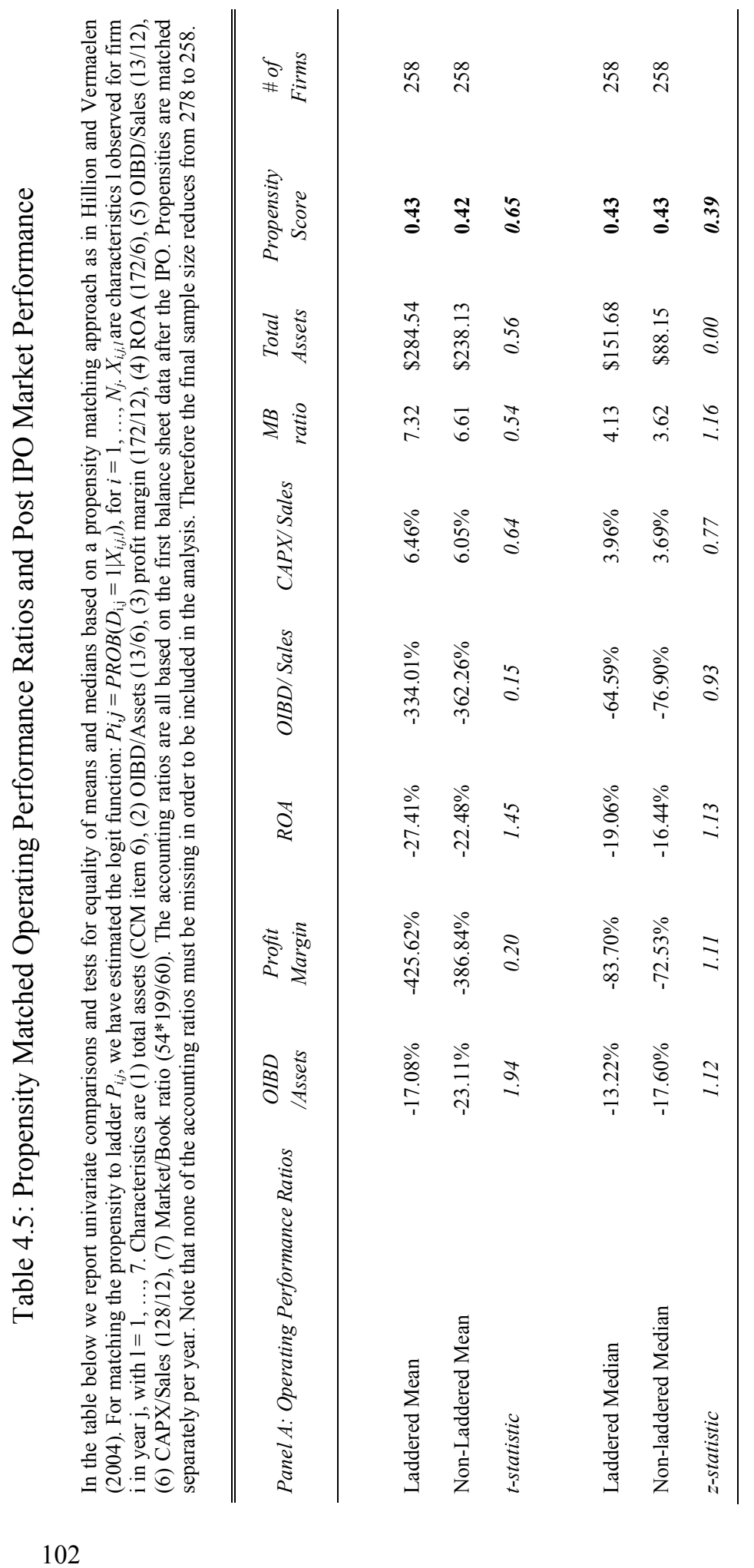




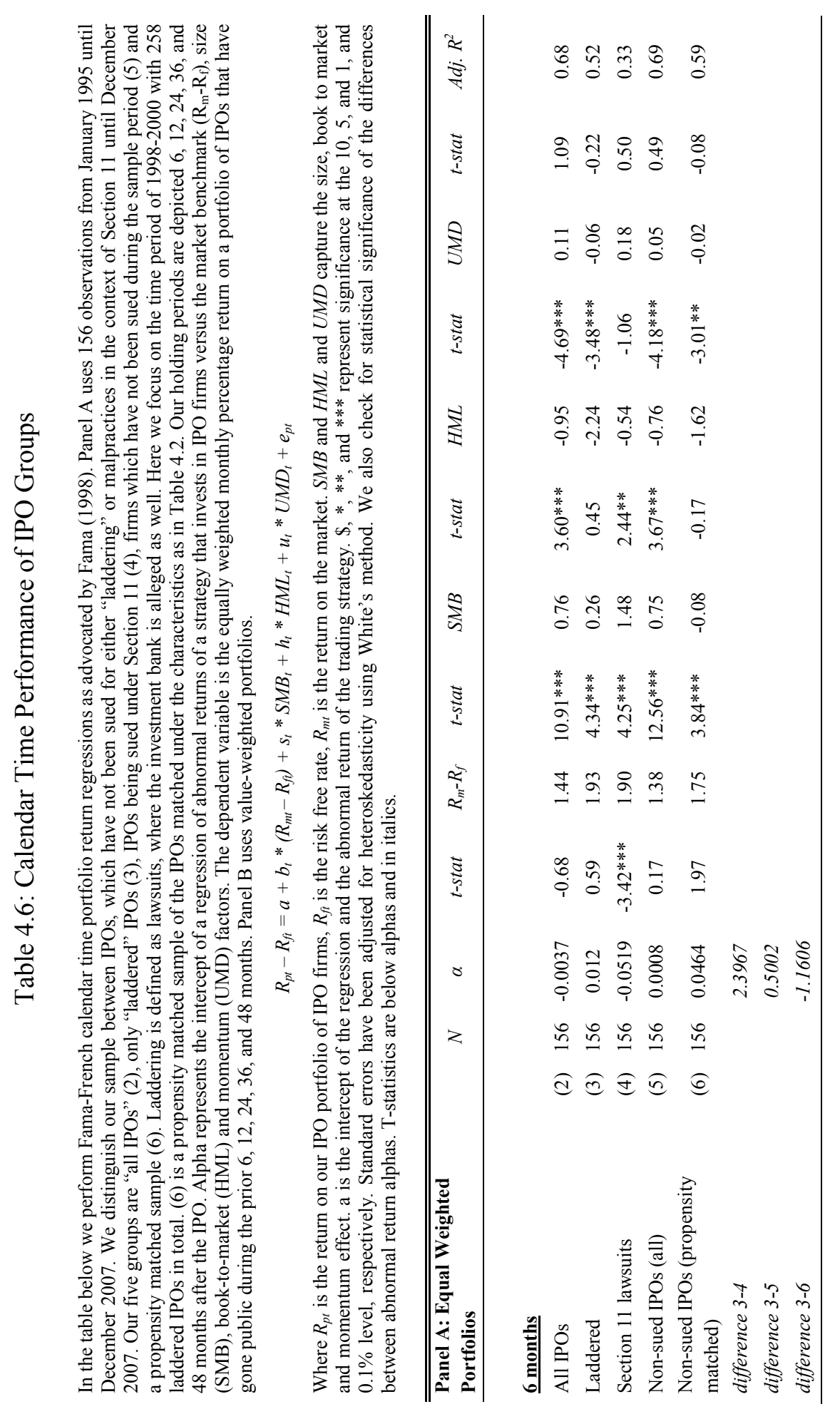




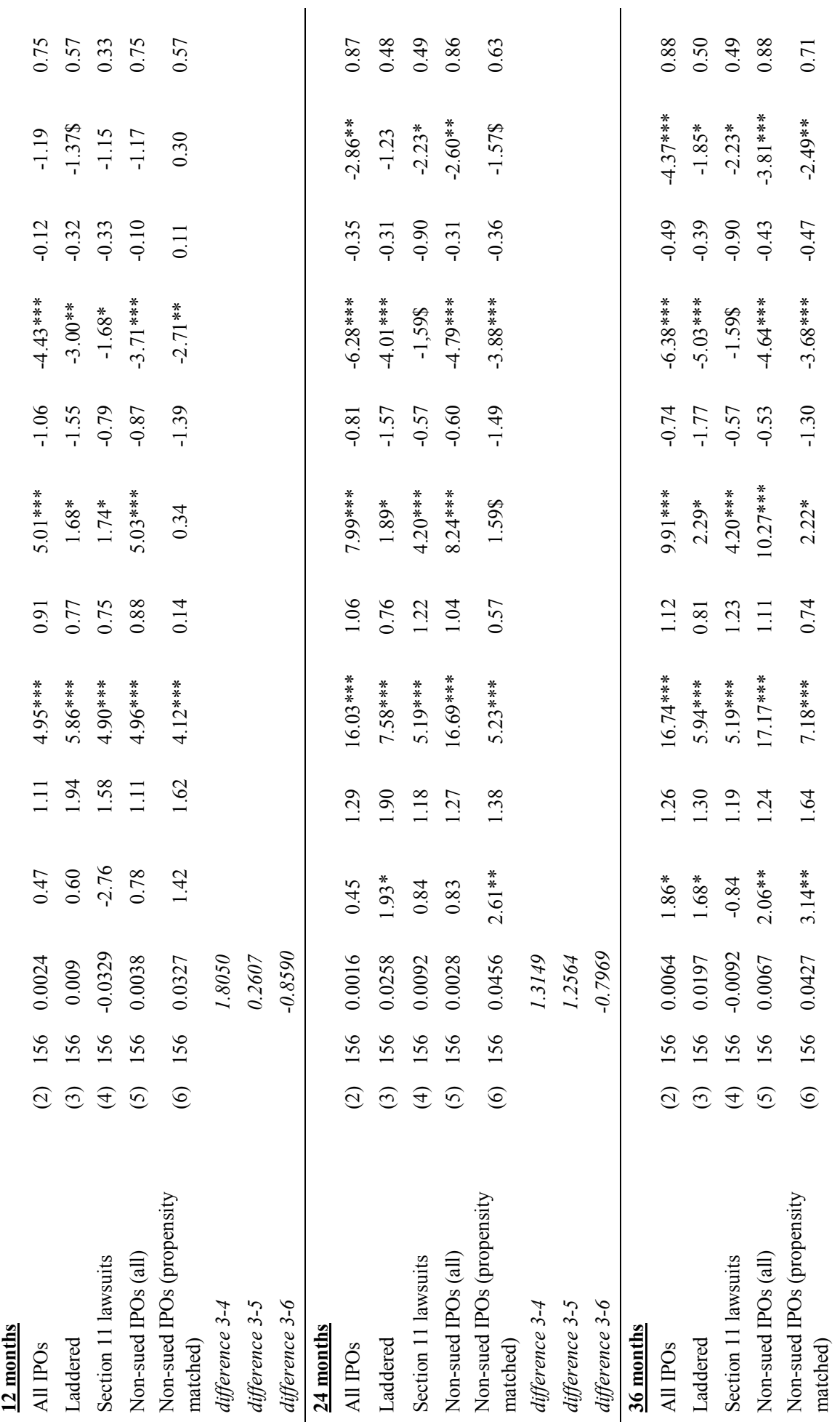




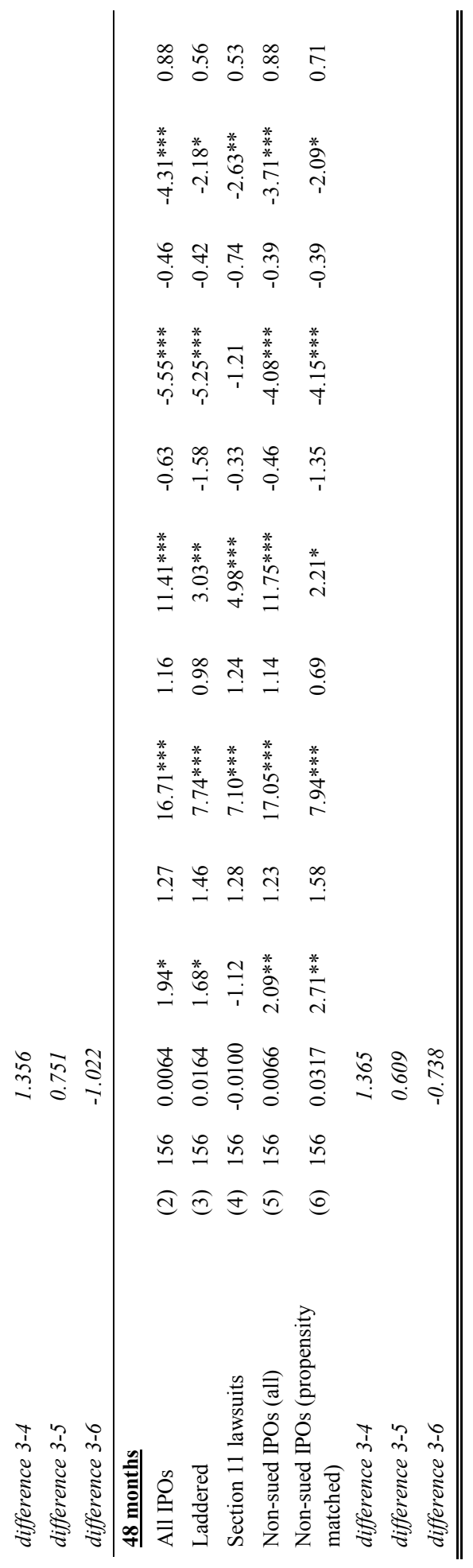




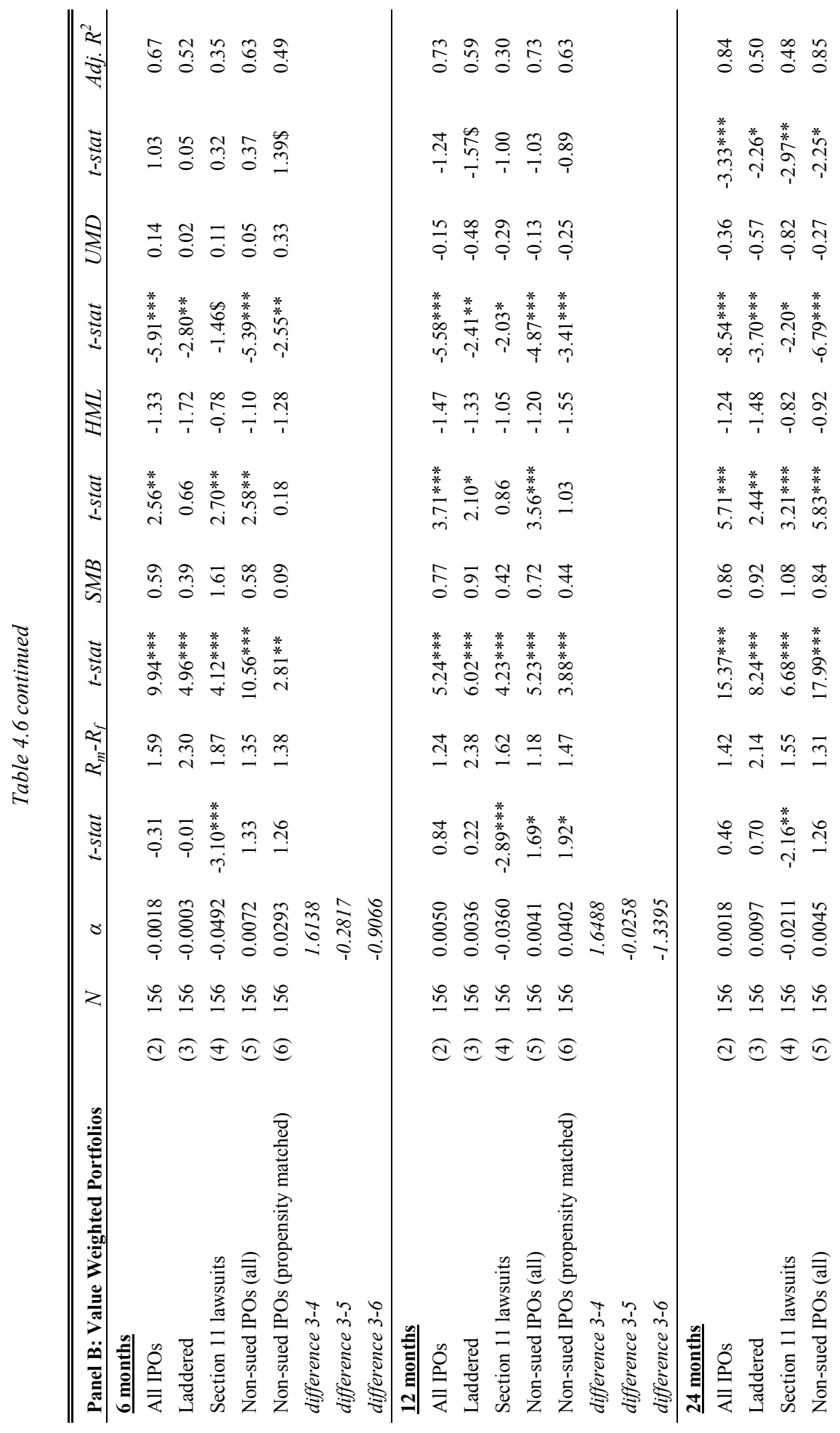




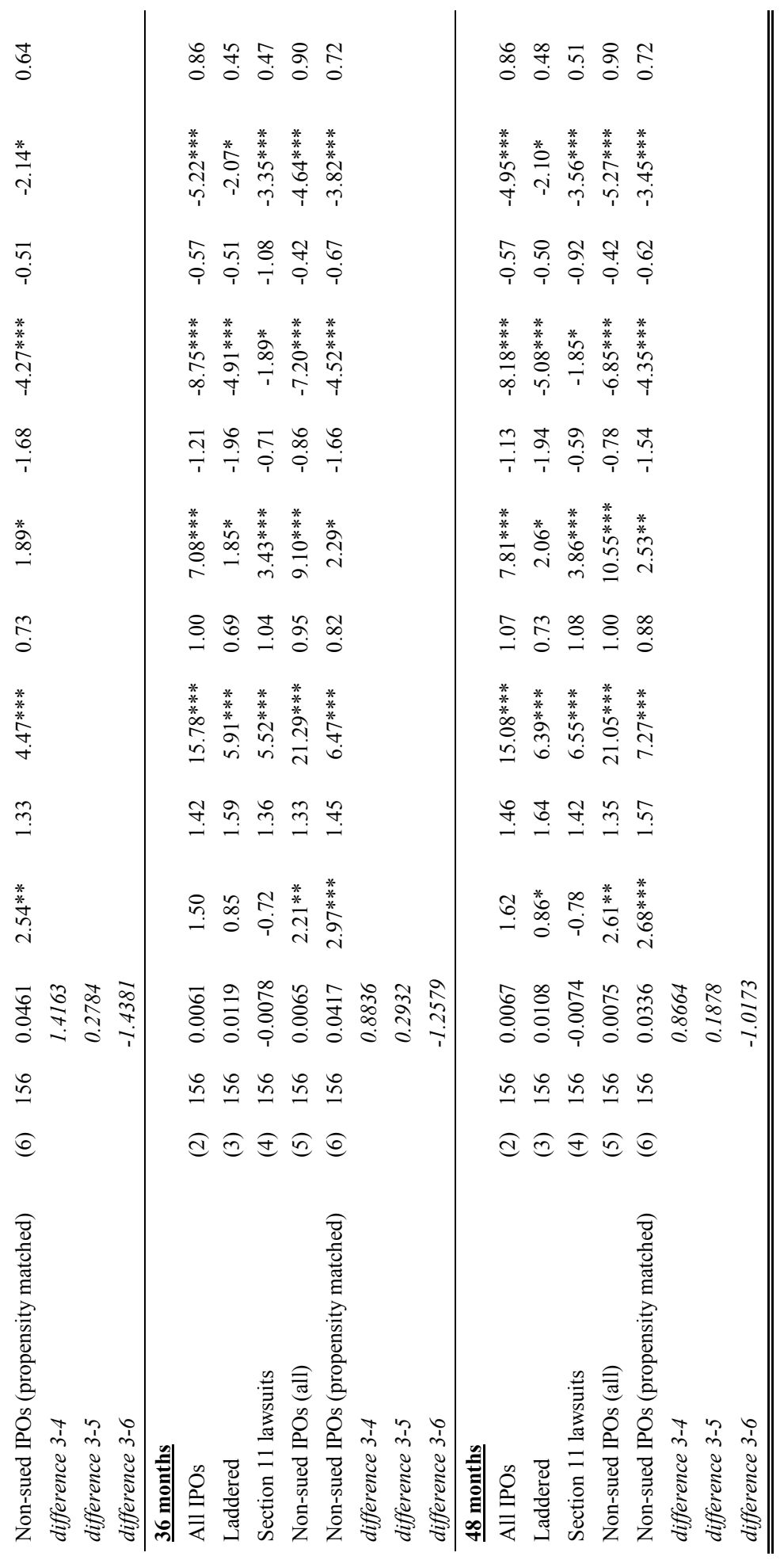




\subsubsection{Laddering and Investment Bank Ownership}

We then directly focus on the investment behavior of the underwriter and proceed as follows. We look at the probability that the investment bank and its financial group invest in the IPO firm. We identify holdings of investment banks and their affiliates ("underwriter ownership") in the underwritten IPO firm at the end of the quarter immediately after IPO $\left(\mathrm{q}_{0}\right)$ until one year later $\left(\mathrm{q}_{4}\right)$ and relate it to postIPO litigation. We distinguish between firms which have been sued for laddering, sued within Section 11 and non-sued IPOs.

The results for the univariate analysis are reported in Table 4.7. We find that in the laddered IPOs, the likelihood that asset managers affiliated with lead underwriter have a stake in the firm is significantly higher than in other types of IPOs. In particular, from Panel A we see that the difference in likelihoods of observing underwriter ownership in laddered IPOs and in non-sued IPOs is $22.6 \%$ (or 96.8\% more relative to unconditional mean) than non-sued IPOs to enjoy a direct investment of the affiliated conglomerate immediately after IPO. This difference in probabilities is $24.0 \%$ in the first quarter after the IPO, $27.9 \%$ in the second quarter, $29.6 \%$ in the third quarter, and $29.6 \%$ in the fourth quarter.

If we consider fraction of shares outstanding (Panel B) the difference in ownership stakes between underwriters in laddered and non-sued IPOs is about $0.30 \%$ (or $114.57 \%$ relative to unconditional mean) - right after the IPO $(0.31 \%$, $0.18 \%, 0.38 \%, 0.36 \%$ after one, two, three and four quarters after the IPO correspondingly). In terms of dollar stake (Panel C) ownership by investment banks is between 5.7 and 13.1 times larger in laddered IPOs than in non-sued firms during one year following the IPO. We find similar results on underwriter ownership when we compare laddered and Section 11 IPOs.

The results for multivariate tests reported in Table 4.8 are consistent with our univariate findings. In particular, being laddered increases the likelihood of underwriter stake immediately after going public by $11.4 \%$ relative non-sued IPOs, and by $9.1 \%, 13.5 \%, 15.1 \%$ and $14.3 \%$ after $1,2,3,4$ quarters correspondingly.

Similarly, underwriters hold on average $0.88 \%$ larger ownership stake as measured by fraction of number of shares in laddered IPOs than non-sued IPOs outstanding immediately after the IPO. This difference in ownership stands at $0.75 \%, 0.61 \%, 0.89 \%$, and $0.67 \%$ for $1,2,3$, and 4 quarters after going public. As in our univariate analysis, Section 11 IPOs do not appear to be different from non-sued IPOs in terms of underwriter ownership. Our results are confirmed in Tobit analysis when we regress the dollar volume of the investment bank stake on the occurrence of either laddering or Section 11 IPOs. 


\section{Table 4.7: Univariate Analysis of Post IPO Underwriter Ownership}

We define the probability of underwriter ownership as all holdings of all entities of the financial conglomerate $j$, which are affiliated with the lead underwriter, company $i$ at time $t$. We distinguish between firms which have been sued according to allegations involving misbehavior of the investment bank ("Laddered IPOs") and firms being sued in the sense of Lowry and Shu (2002), which are termed "Section 11 IPOs". Panel A investigates the percentage of cases in which the brand of the underwriting investment bank holds shares in the IPO firm. Panel B looks at the market value of shares relative to the total market capitalization of the IPO firm at that time. Panel C reports the dollar volumes of the brand's position in millions of dollars.

\begin{tabular}{|c|c|c|c|c|c|c|}
\hline $\begin{array}{l}\text { Panel A: Probability } \\
\text { of IB stake in IPO } \\
\text { Firm }\end{array}$ & $N$ & $\begin{array}{l}\text { IB holdings } \\
\text { during IPO } \\
\text { Quarter }\end{array}$ & $\begin{array}{l}\text { IB holdings } \\
\text { at } Q 1\end{array}$ & $\begin{array}{l}I B \text { holdings } \\
\text { at } Q^{2}\end{array}$ & $\begin{array}{l}\text { IB holdings } \\
\text { at Q3 }\end{array}$ & $\begin{array}{l}\text { IB holdings } \\
\text { at } Q 4\end{array}$ \\
\hline Laddered IPO & 238 & 0.42 & 0.508 & 0.559 & 0.601 & 0.655 \\
\hline Section 11 IPO & 34 & 0.265 & 0.265 & 0.324 & 0.324 & 0.353 \\
\hline \multirow[t]{2}{*}{ Non-sued IPO (all) } & 1151 & 0.194 & 0.268 & 0.28 & 0.305 & 0.359 \\
\hline & t-test & & & & & \\
\hline \multirow[t]{3}{*}{ Test for differences } & $1-3$ & $6.64 * * *$ & $6.86 * * *$ & $7.99 * * *$ & $8.56 * * *$ & $8.75 * * *$ \\
\hline & $1-2$ & $1.87^{*}$ & $2.92 * * *$ & $2.69 * * *$ & $3.17 * * *$ & $3.41 * * *$ \\
\hline & $2-3$ & 0.92 & -0.05 & 0.52 & 0.23 & -0.07 \\
\hline $\begin{array}{l}\text { Panel B: Fractional } \\
\text { Shares Held (Frsh) }\end{array}$ & $N$ & $\begin{array}{l}\text { IB Frsh at } \\
\text { IPO Quarter }\end{array}$ & $\begin{array}{c}I B \\
\text { Frsh } \\
\text { at } Q 1\end{array}$ & $\begin{array}{c}I B \\
\text { Frsh } \\
\text { at } Q^{2}\end{array}$ & $\begin{array}{c}I B \\
\text { Frsh } \\
\text { at Q3 }\end{array}$ & $\begin{array}{c}I B \\
\text { Frsh } \\
\text { at } Q 4\end{array}$ \\
\hline Laddered IPO & 238 & $0.51 \%$ & $0.62 \%$ & $0.51 \%$ & $0.73 \%$ & $0.72 \%$ \\
\hline Section 11 IPO & 34 & $0.28 \%$ & $0.34 \%$ & $0.36 \%$ & $0.58 \%$ & $0.39 \%$ \\
\hline \multirow[t]{2}{*}{ Non-sued IPO (all) } & 1151 & $0.21 \%$ & $0.31 \%$ & $0.33 \%$ & $0.35 \%$ & $0.36 \%$ \\
\hline & t-test & & & & & \\
\hline \multirow[t]{3}{*}{ Test for differences } & $1-3$ & $2.34 * *$ & $1.94 *$ & 1.14 & $2.46^{* *}$ & $2.29 * *$ \\
\hline & $1-2$ & 0.97 & 1.21 & 0.74 & 0.49 & 1.51 \\
\hline & $2-3$ & 0.51 & 0.08 & 0.02 & 0.77 & -0.02 \\
\hline $\begin{array}{l}\text { Panel C: Dollar } \\
\text { (DVOL) Volume of } \\
\text { Position }\end{array}$ & $N$ & $\begin{array}{l}\text { IB DVOL at } \\
\text { IPO Quarter }\end{array}$ & $\begin{array}{c}I B \\
D V O L \\
\text { at } Q 1\end{array}$ & $\begin{array}{c}I B \\
D V O L \\
\text { at } Q 2\end{array}$ & $\begin{array}{c}I B \\
D V O L \\
\text { at } Q 3\end{array}$ & $\begin{array}{c}I B \\
D V O L \\
\text { at } Q 4\end{array}$ \\
\hline Laddered IPO & 238 & $\$ 10.09$ & $\$ 14.85$ & $\$ 12.75$ & $\$ 24.03$ & $\$ 26.37$ \\
\hline Section 11 IPO & 34 & $\$ 0.48$ & $\$ 0.49$ & $\$ 0.69$ & $\$ 0.73$ & $\$ 0.36$ \\
\hline \multirow[t]{2}{*}{ Non-sued IPO (all) } & 1151 & $\$ 0.77$ & $\$ 2.60$ & $\$ 1.48$ & $\$ 1.89$ & $\$ 2.48$ \\
\hline & t-test & & & & & \\
\hline \multirow[t]{3}{*}{ Test for differences } & $1-3$ & $5.29 * * *$ & $2.62 * *$ & $5.54 * * *$ & $4.71 * * *$ & $4.12 * * *$ \\
\hline & $1-2$ & $2.55 * *$ & $2.06 * *$ & $2.91 * * *$ & $2.32 * *$ & $2.12 * *$ \\
\hline & $2-3$ & -0.25 & -0.23 & -0.37 & -0.38 & -0.49 \\
\hline
\end{tabular}




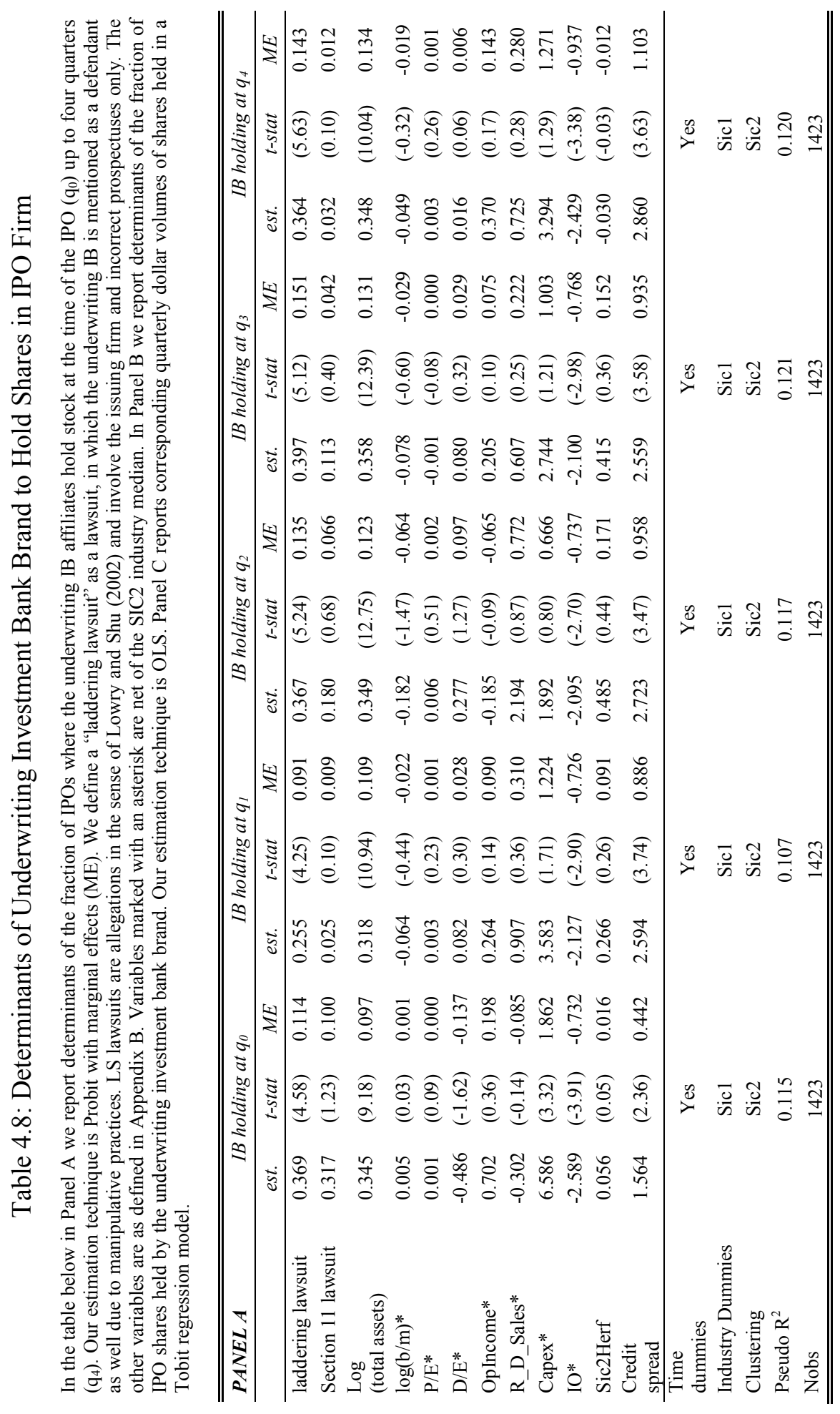




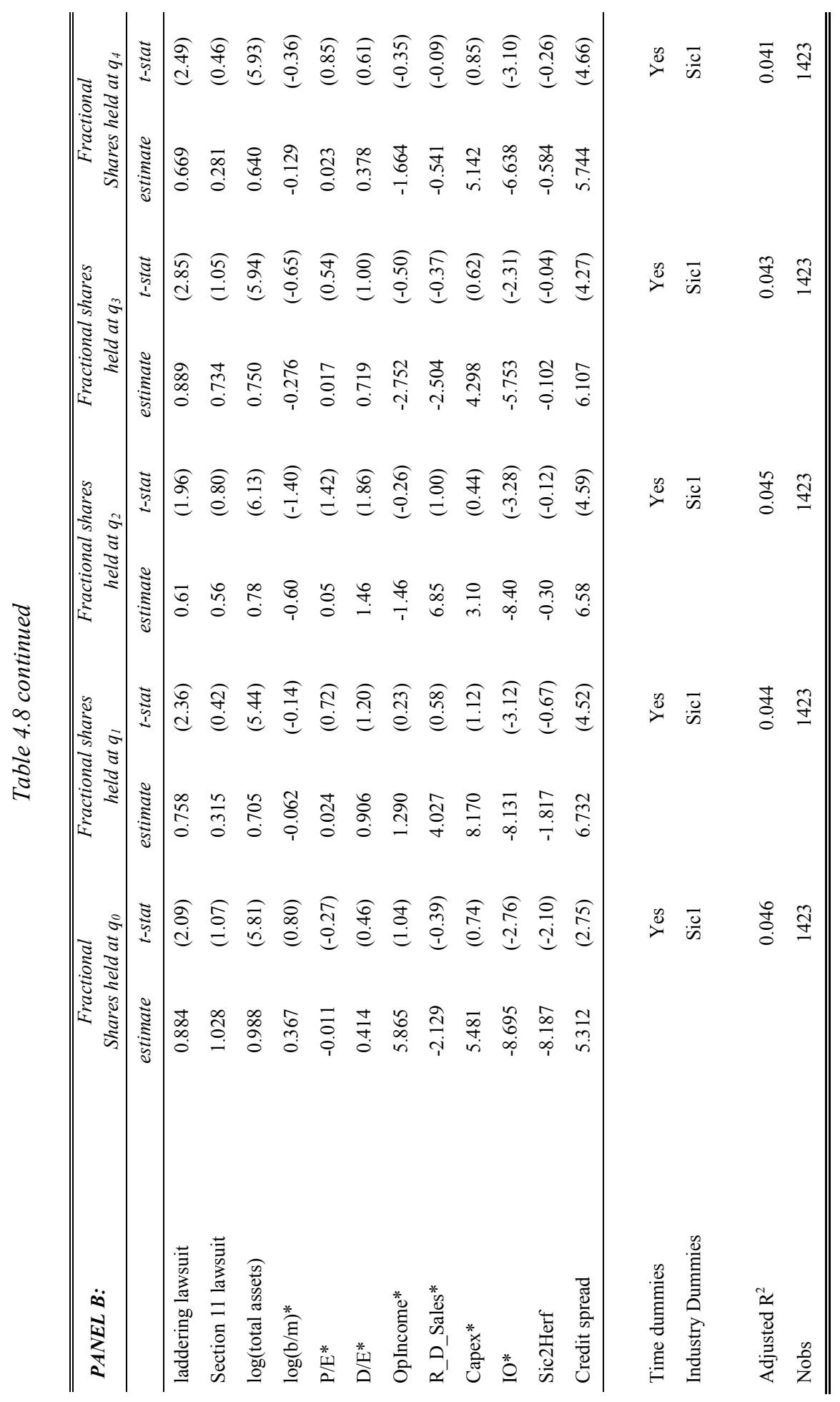




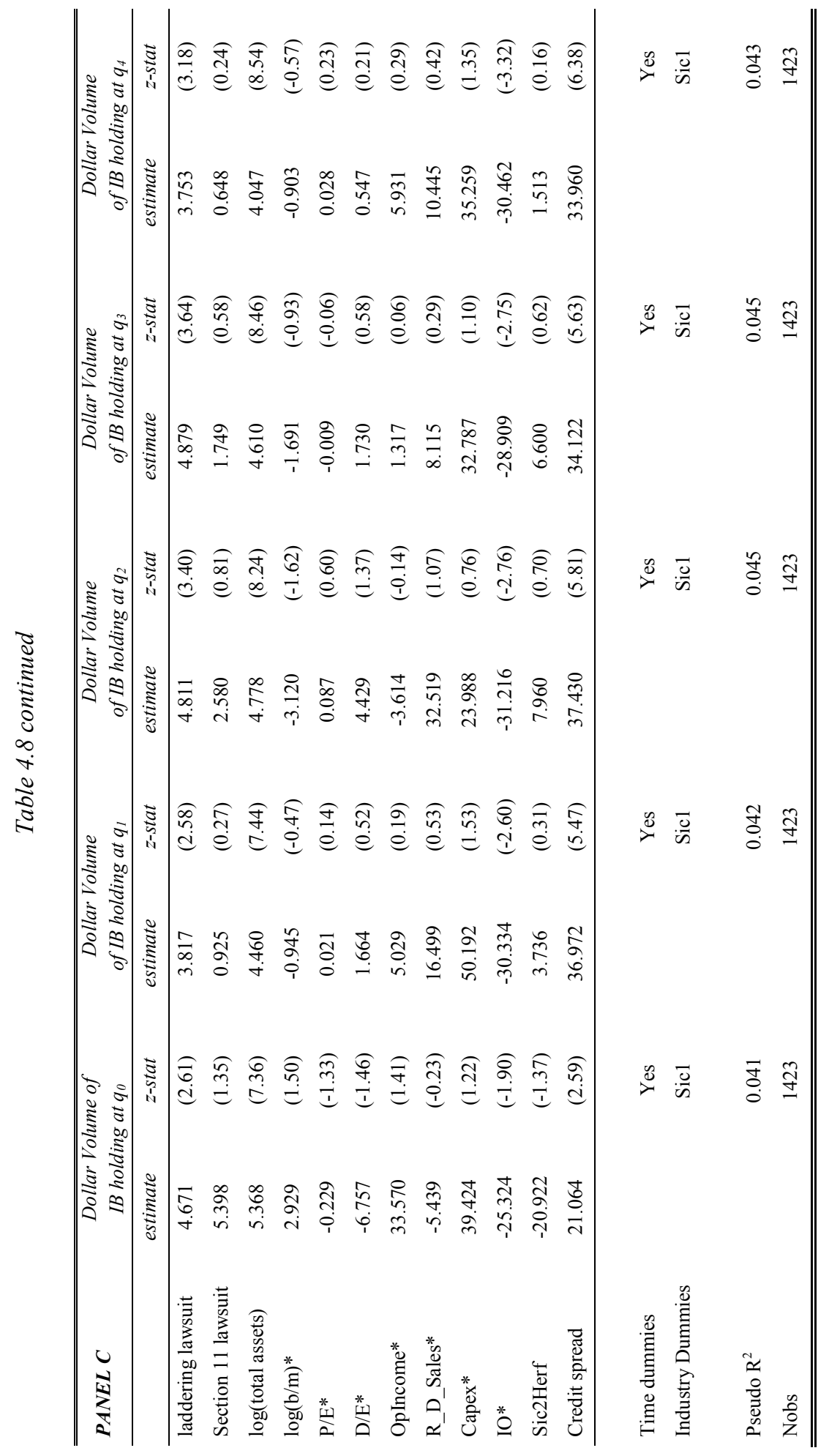




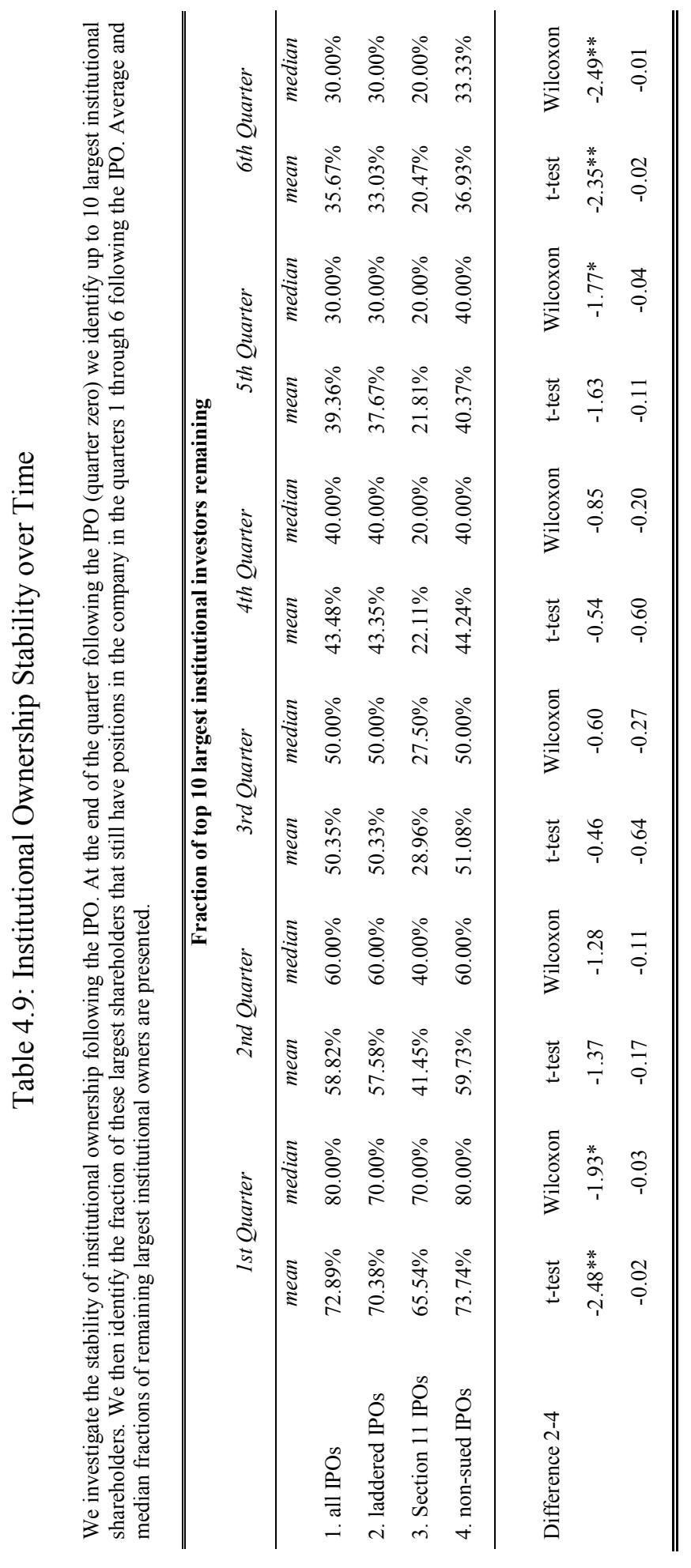


Furthermore we also note in Table 4.9 that the institutional share ownership is remarkably stable. We do so by identifying the ten largest investor "brands" in our IPO groups and investigate their ownership stability. Only in the fifth quarter after the IPO, large institutional ownership in laddered IPOs becomes outnumbered by a matched sample of non-laddered IPOs. This stability in ownership further contributes to price stability in the aftermarket. Overall, these results suggest that laddered IPOs enjoy a much stronger direct support by underwriting investment banks.

\subsection{Laddering and Insider Behavior}

We now investigate the potential beneficiaries of the investment bank's behavior: the insiders of the IPO firms. We consider the trading activity both prior and post lock-up expiration and its impact on stock price. As we argued above, if laddering is a way of helping the insiders by getting the investment bank involved to stabilize the price and allow the insiders to sell with limited price impact, we expect the insiders to avail of this option by trading more intensely after the IPO and such trades to have limited impact.

\subsubsection{Laddering and Insider Trading}

We start by looking at insider trading behavior and market-wide trading volume of the IPO stock. We compare insider trading in laddered IPOs to that of other IPO groups - Section 11 IPOs, full sample of non-sued IPOs as well as comparable non-sued IPOs. ${ }^{1}$ We consider both dollar trading volume, the number of transactions executed and insider sales to purchase index (ISPI) (e.g., Lang and John, 1991, Damodaran and Liu, 1993). With respect to post IPO stock trading volumes (cf. Table 4.10), differences during the lock-up period are less pervasive. After the expiration of the lock-up, however, trading volumes differ significantly. There is significantly higher trading volume 180 days after the IPO.

For each of these groups of IPOs, we look at the transactions of the insiders after the IPO. We follow Thomson Reuters and define 4 levels of insider transactions. ${ }^{2}$ We only consider insider transactions from level 1 and level 2 . The reasons is that only level 1 and 2 insiders resemble corporate executives and key decision makers with potential access to inside information.

\footnotetext{
${ }^{1}$ In our matched firm analysis a non-sued IPO can be a match for several laddered IPOs due to limited size of the control group on NASDAQ, i.e. we allow double-counting. The results are qualitatively unaffected when we remove multiple observations of matched firms.

${ }^{2}$ For the description of insider classification please refer to Thomson Reuters manual. 


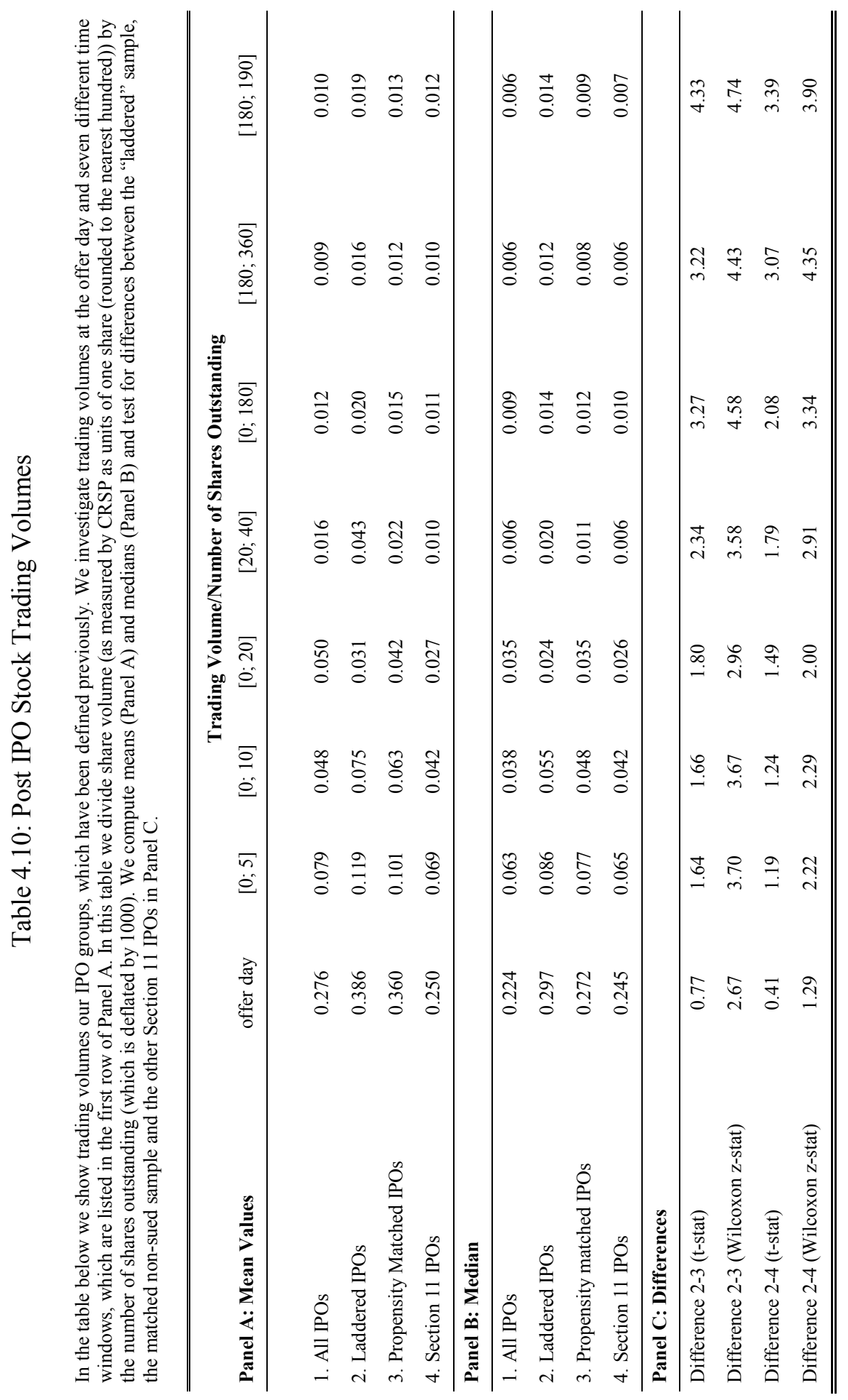


We consider open market transactions and include option exercises. We restrict our sample to Thomson Reuters cleanse indicators " $R$ ", " $H$ ", and "C". We consider both the transaction volumes - i.e., transaction price times the number of shares tendered - and the transaction trades - i.e., the counts of every trade of an officer as a single observation aggregated during the respective time period.

The results for the number of transactions are reported in Table 4.11. We find that in $38.33 \%$ of laddered IPOs insiders sell their shares prior to lock-period expiration. This is significantly more often than $32.79 \%$ in the case of Section 11 IPOs, $29.25 \%$ for full sample of non-sued IPOs and $24.11 \%$ for similar non-sued IPOs. When we look at insiders selling activity over one month after the lock-up period expiration in $37.63 \%$ of laddered IPOs insiders sell some of their shares. This should be compared to $27.87 \%, 20.57 \%$ and $25.53 \%$ for Section 11 , all non-sued and similar non-sued IPOs respectively.

\section{Table 4.11: Summary Statistics of Insider Trading Activity}

We show summary statistics of insider open market and private trading in private trading in the time periods of IPO until lock-up expiration (usually 180 days): 30, 90, and 180 days post lock-up expiration. Insider transaction data is obtained from Thomson Reuters. The sample covers the period of 1995-2007. Our five sample groups are as defined in earlier tables. Sample size is 1983 for non-sued IPOs, 287 for laddered IPOs, 61 for Section 11 IPOs, and 253 for our propensity matched sample, respectively.

\begin{tabular}{|c|c|c|c|c|}
\hline $\begin{array}{l}\text { Panel A: non-sued } \\
\text { (Group 1) }\end{array}$ & [IPO; lock-up] & [lock-up; 30] & [lock-up; 90] & [lock-up; 180] \\
\hline Number of firms & 1983 & 1983 & 1983 & 1983 \\
\hline $\begin{array}{l}\% \text { of firms with } \\
\text { insider purchases }\end{array}$ & $56.68 \%$ & $10.29 \%$ & $22.19 \%$ & $34.75 \%$ \\
\hline $\begin{array}{l}\% \text { of firms with } \\
\text { insider sales }\end{array}$ & $29.25 \%$ & $20.57 \%$ & $38.93 \%$ & $51.79 \%$ \\
\hline $\begin{array}{l}\text { Number of } \\
\text { Insider Purchases }\end{array}$ & 6721 & 767 & 2677 & 5190 \\
\hline $\begin{array}{l}\text { Number of } \\
\text { Insider Sales }\end{array}$ & 3803 & 5505 & 19924 & 44978 \\
\hline $\begin{array}{l}\text { average \# of } \\
\text { purchase per firm }\end{array}$ & 3.39 & 0.39 & 1.35 & 2.62 \\
\hline $\begin{array}{l}\text { average \# of } \\
\text { purchase per firm }\end{array}$ & 1.92 & 2.78 & 10.05 & 22.68 \\
\hline $\begin{array}{l}\text { Average Dollar Volume } \\
\text { Purchases per Firm }\end{array}$ & $\$ 441,001.40$ & $\$ 33,414.24$ & $\$ 106,087.10$ & $\$ 196,517.20$ \\
\hline $\begin{array}{l}\text { Average Dollar Volume } \\
\text { Sales per Firm }\end{array}$ & $\$ 3,167,308.00$ & $\$ 1,270,806.00$ & $\$ 3,292,976.00$ & $\$ 5,878,545.00$ \\
\hline \multicolumn{5}{|l|}{$\begin{array}{l}\text { Panel B: laddered } \\
\text { firms (Group 2) }\end{array}$} \\
\hline Number of firms & 287 & 287 & 287 & 287 \\
\hline $\begin{array}{l}\% \text { of firms with } \\
\text { insider purchases }\end{array}$ & $60.28 \%$ & $13.59 \%$ & $24.39 \%$ & $33.80 \%$ \\
\hline $\begin{array}{l}\% \text { of firms with } \\
\text { insider sales }\end{array}$ & $38.33 \%$ & $37.63 \%$ & $59.23 \%$ & $71.43 \%$ \\
\hline
\end{tabular}




\begin{tabular}{|c|c|c|c|c|}
\hline $\begin{array}{l}\text { Number of } \\
\text { Insider Purchases }\end{array}$ & 1254 & 127 & 239 & 548 \\
\hline $\begin{array}{l}\text { Number of } \\
\text { Insider Sales }\end{array}$ & 1149 & 1516 & 3713 & 7364 \\
\hline $\begin{array}{l}\text { average \# of } \\
\text { purchase per firm }\end{array}$ & 4.37 & 0.44 & 0.83 & 1.91 \\
\hline $\begin{array}{l}\text { average \# of } \\
\text { purchase per firm }\end{array}$ & 4.00 & 5.28 & 12.94 & 25.66 \\
\hline $\begin{array}{l}\text { Average Dollar Volume } \\
\text { Purchases per Firm }\end{array}$ & $\$ 1,735,925.00$ & $\$ 482,109.60$ & $\$ 1,986,091.00$ & $\$ 2,093,420.00$ \\
\hline $\begin{array}{l}\text { Average Dollar Volume } \\
\text { Sales per Firm }\end{array}$ & $\$ 14,173,705.00$ & $\$ 7,952,907.00$ & $\$ 18,289,255.00$ & $\$ 36,987,250.00$ \\
\hline \multicolumn{5}{|l|}{$\begin{array}{l}\text { Panel C: Section } 11 \\
\text { Firms (Group 3) } \\
\end{array}$} \\
\hline Number of firms & 61 & 61 & 61 & 61 \\
\hline $\begin{array}{l}\% \text { of firms with } \\
\text { insider purchases }\end{array}$ & $50.82 \%$ & $21.31 \%$ & $39.34 \%$ & $45.90 \%$ \\
\hline $\begin{array}{l}\% \text { of firms with } \\
\text { insider sales }\end{array}$ & $32.79 \%$ & $27.87 \%$ & $36.07 \%$ & $45.90 \%$ \\
\hline $\begin{array}{l}\text { Number of } \\
\text { Insider Purchases }\end{array}$ & 182 & 37 & 133 & 173 \\
\hline $\begin{array}{l}\text { Number of } \\
\text { Insider Sales }\end{array}$ & 107 & 1383 & 1490 & 1661 \\
\hline $\begin{array}{l}\text { average \# of } \\
\text { purchase per firm }\end{array}$ & 2.98 & 0.61 & 2.18 & 2.84 \\
\hline $\begin{array}{l}\text { average \# of } \\
\text { purchase per firm }\end{array}$ & 1.75 & 22.67 & 24.43 & 27.23 \\
\hline $\begin{array}{l}\text { Average Dollar Volume } \\
\text { Purchases per Firm }\end{array}$ & $\$ 419,453.60$ & $\$ 16,258.19$ & $\$ 101,163.80$ & $\$ 131,990.40$ \\
\hline $\begin{array}{l}\text { Average Dollar Volume } \\
\text { Sales per Firm }\end{array}$ & $\$ 3,335,340.00$ & $\$ 1,698,010.00$ & $\$ 2,395,274.00$ & $\$ 3,489,346.00$ \\
\hline \multicolumn{5}{|l|}{$\begin{array}{l}\text { Panel D: Matched } \\
\text { Sample (Group 4) }\end{array}$} \\
\hline Number of firms & 253 & 253 & 253 & 253 \\
\hline $\begin{array}{l}\% \text { of firms with } \\
\text { insider purchases }\end{array}$ & $60.08 \%$ & $16.21 \%$ & $23.72 \%$ & $31.23 \%$ \\
\hline $\begin{array}{l}\% \text { of firms with } \\
\text { insider sales }\end{array}$ & $28.46 \%$ & $31.23 \%$ & $44.66 \%$ & $56.52 \%$ \\
\hline $\begin{array}{l}\text { Number of } \\
\text { Insider Purchases }\end{array}$ & 1137 & 214 & 345 & 585 \\
\hline $\begin{array}{l}\text { Number of } \\
\text { Insider Sales }\end{array}$ & 501 & 761 & 1476 & 2789 \\
\hline $\begin{array}{l}\text { average \# of } \\
\text { purchase per firm }\end{array}$ & 4.49 & 0.85 & 1.36 & 2.31 \\
\hline $\begin{array}{l}\text { average \# of } \\
\text { purchase per firm }\end{array}$ & 1.98 & 3.01 & 5.83 & 11.02 \\
\hline $\begin{array}{l}\text { Average Dollar Volume } \\
\text { Purchases per Firm }\end{array}$ & $\$ 1,727,802.00$ & $\$ 40,539.68$ & $\$ 108,165.20$ & $\$ 152,865.40$ \\
\hline $\begin{array}{l}\text { Average Dollar Volume } \\
\text { Sales per Firm }\end{array}$ & $\$ 4,509,162.00$ & $\$ 624,337.90$ & $\$ 3,393,728.00$ & $\$ 5,461,906.00$ \\
\hline \multicolumn{5}{|l|}{$\begin{array}{l}\text { Panel E: Differences in } \\
\text { Selling Volume (t-stats) }\end{array}$} \\
\hline (Group 2 - 4) & $2.62 * * *$ & $4.17 * * *$ & $4.70^{* * *}$ & $5.37 * * *$ \\
\hline (Group 2 - 3) & $2.06 * *$ & $1.74^{*}$ & $2.45^{* *}$ & $2.78 * * *$ \\
\hline (Group 1 - 2) & $8.01 * * *$ & $8.22 * * *$ & $9.77 * * *$ & $11.50 * * *$ \\
\hline
\end{tabular}


When we look at transaction dollar volume sales we observe that insider sales in laddered IPOs are also significantly larger. In particular, prior to lock-period expiration insiders in laddered IPOs on average sold over 14 million dollars worth of stock, which is more than twice as any other IPO group. Results are very similar if we look at insider selling post lock-up period. When we consider insider sales-topurchase index (ISPI) in Table 4.12, we see that insiders in laddered IPO are significantly more likely to be net sellers of their shares than insiders in other IPO groups. ${ }^{33}$ For example, if we condition that there has been at least $1(1.5,2)$ insider transactions per week in the pre-lock-up period there are $2.79 \%(2.09 \%, 1.39 \%)$ of laddered IPOs whose insiders are net sellers over this period. This is significantly more than $0.50 \%(0.10 \%, 0.10 \%)$ in the case of non-sued IPOs, $0 \%(0 \%, 0 \%)$ for Section 11 IPOs and $1.19 \%(0 \%, 0 \%)$ for similar non-sued IPOs. The results are economically and qualitatively even stronger if we consider post-lock up period.

\subsubsection{Laddering and the Market Impact of Insider Trading}

What are the stock price implications of this behavior? We look at the stock price reaction to the sales of the insiders conditioning on whether the IPO is laddered. We estimate abnormal stock performance of IPO firms around the selling activity by insiders. The problem with defining abnormal returns for short-horizon event studies in IPOs is 1) the absence of an estimation period for computing expected returns and 2 ) the difficulty of obtaining a set of comparable companies. Recall from Tables 4.2 and 4.5 that our analysis deals with young growth companies with little or no history of profitability. One solution is to compare stock performance subsequent to an event to the performance of the own stock price during a reasonably distant comparison period.

\footnotetext{
${ }^{33}$ We use a measure of standardized intensity of insider trading according to John and Lang (1991) and Damodaran and Liu (1993). We aggregate insider trades over a pre-defined time period $t$, where $t$ is the number of days elapsed a) between offer date and lock-up expiration (for early releases) and b) between lock-up expiration until maximum 180 trading days. The measure is computed the following way: ISPI1 $=(\mathrm{NP}-\mathrm{NS}) /(\mathrm{NP}+\mathrm{NS})$, where $\mathrm{NP}$ is the aggregate number of insider purchases in time interval $\mathrm{t}$ and $\mathrm{NS}$ is the corresponding number of insider sale transactions. This index is bounded between -1 and +1 . The interpretation of e.g. 0.2 would be that in $20 \%$ of the total number of transactions, insider purchases exceeded insider sales. A value of e.g. -1 means that of all transactions, $100 \%$ were sales transactions. However due to the bounded nature of this measure, a very low number of transactions can potentially result in very high/low values of the ISPI. This is why, in line with previous studies, we adopt the use of so-called threshold values for the insider transactions to be informative. We specify minimum levels of transactions per trading week which have to be exceeded for the insider trading behavior to be informative. So a threshold of 2 for a [IPO; lock-up] period implies that there should be at least 2 transactions per trading week for a company to have its ISPI1 index calculated.
} 


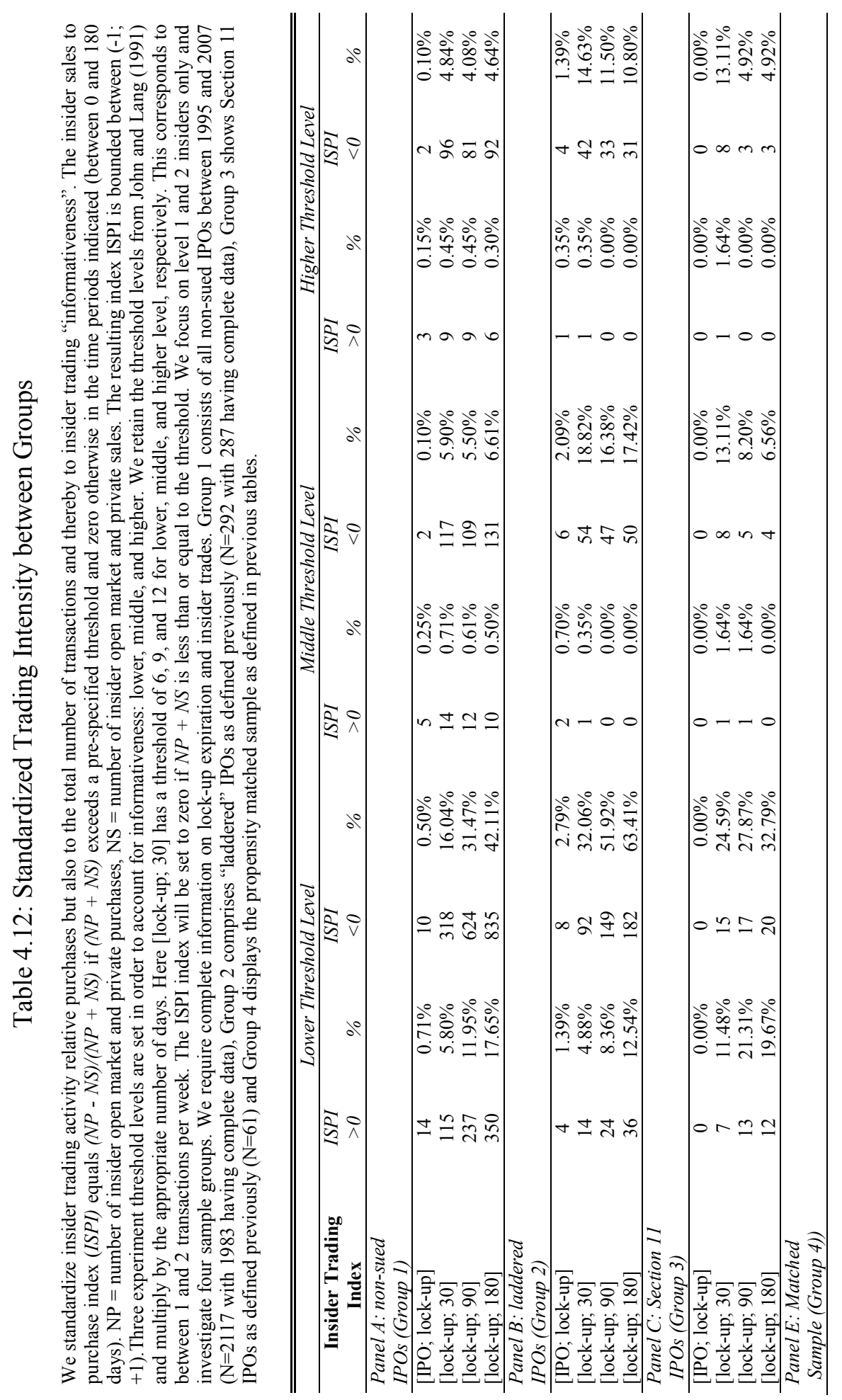




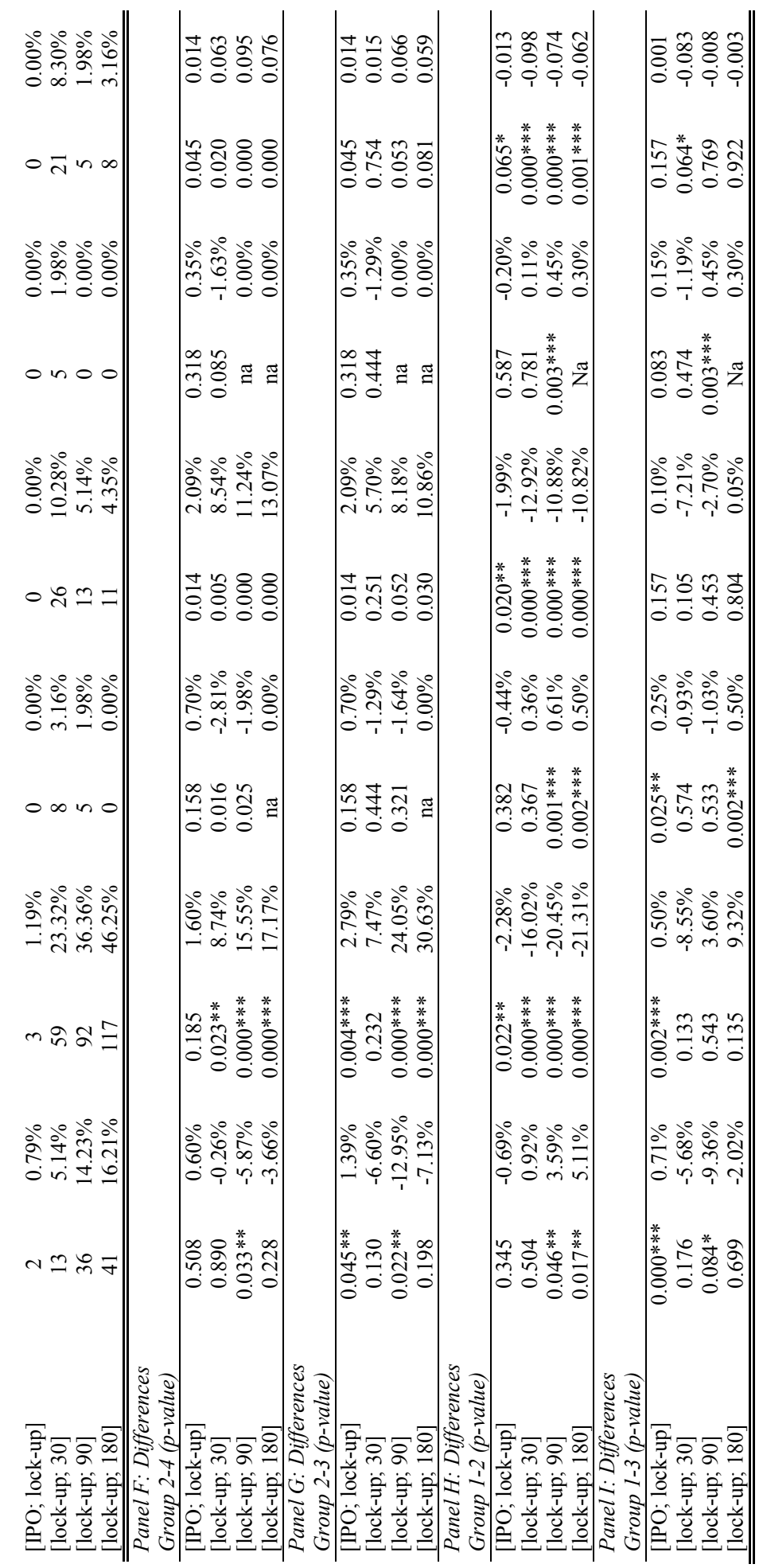


We define the abnormal return as the cumulative return on the company stock less return on the company over the control window. In such a way we aim to adjust for the systematic differences in exposure to risk factors between companies in difference IPO groups. We consider a $(-1 ;+1)$ days event window with a $(-6 ;-4)$ days control window, as well as a $(-3 ;+3)$ days event window with $(-10 ;-4)$ days control window. We report the results in Table 4.13 . They show that the stock price reaction around insider sales is very similar for laddered IPOs and non-sued IPOs. This holds true whether we consider insider sales over two year period after the IPO or pre-lock period sales only. This provides evidence that higher trading activity by the insiders is not accompanied by higher price impact. Laddering appears to be a way of providing price support to the insiders that lasts for the length of the lock-up period and beyond that and allows the insiders to sell with minimal market impact.

\section{Table 4.13: Stock Market Reaction to Insider Sales}

We estimate abnormal stock performance of IPO companies around sales by insiders. $\mathrm{fCAR}_{3}$ is the cumulative return on the company stock over the $(-1 ;+1)$ days window around the date of sale less return on the company over days $(-6 ;-4)$. $\mathrm{fCAR}_{7}$ is the cumulative return on the company stock over the $(-3 ;+3)$ days window around the date of sale less return on the company over days $(-10 ;-4)$. All other variables are as defined previously.

\begin{tabular}{lccccc}
\hline \hline \multicolumn{2}{l}{ Panel A: all insiders sales over 2 years following IPO } \\
\hline & $n$ & mean & median & mean & median \\
\hline 1. all IPOs & 93803 & $0.00 \%$ & $0.00 \%$ & $-0.44 \%$ & $-0.18 \%$ \\
2. laddered IPOs & 20634 & $0.10 \%$ & $0.04 \%$ & $-0.38 \%$ & $-0.42 \%$ \\
3. Section 11 IPOs & 1684 & $-0.33 \%$ & $-0.06 \%$ & $-1.24 \%$ & $-0.54 \%$ \\
4. non-sued IPOs & 71485 & $-0.02 \%$ & $0.00 \%$ & $-0.44 \%$ & $-0.12 \%$ \\
\hline Difference 2-4 & & t-test & Wilcoxon & t-test & Wilcoxon \\
& & 1.24 & 0.4 & 0.45 & -0.65 \\
& & $--0.22)$ & -0.35 & -0.65 & $(-0.26)$ \\
\hline
\end{tabular}

Panel B: early releases (pre-lock-up termination sales)

\begin{tabular}{lccccc}
\hline & \multicolumn{2}{c}{$\mathrm{fCAR}_{3}$} & \multicolumn{2}{c}{$\mathrm{fCAR}_{7}$} \\
& $\mathrm{n}$ & mean & median & mean & median \\
\hline 1. all IPOs & 1192 & $-0.37 \%$ & $0.00 \%$ & $-0.32 \%$ & $-0.04 \%$ \\
2. laddered IPOs & 307 & $-0.04 \%$ & $0.81 \%$ & $-0.34 \%$ & $0.92 \%$ \\
3. Section 11 IPOs & 21 & $4.61 \%$ & $2.50 \%$ & $5.35 \%$ & $0.31 \%$ \\
4. non-sued IPOs & 864 & $-0.60 \%$ & $-0.05 \%$ & $-0.45 \%$ & $-0.18 \%$ \\
\hline Difference 2-4 & & t-test & Wilcoxon & t-test & Wilcoxon \\
& & 0.57 & -0.86 & 0.07 & 0.13 \\
& & -0.58 & -0.2 & -0.95 & -0.45 \\
\hline \hline
\end{tabular}




\subsection{Laddering again?}

Now that we have defined the main characteristics of laddering, we use them to ask whether the regulatory changes in 2000 determined a disappearance of this phenomenon. We proceed as follows. First, we determine whether we can predict the likelihood of the firms being laddered during the period of 2001-2007 based on the estimated parameters from a binary probit model regressing the likelihood of IPOs being laddered during the period of 1995-2000. Then, we focus on the firms that have been identified as "laddered" and we determine whether they display the same characteristics that distinguished laddered firms.

We start by verifying that characteristics that we identified as drivers of laddering (high underpricing, high underwriter rank, etc) are indeed helpful to predict laddering. To do this, we estimate the relation between likelihood of laddering and its characteristics for 1995-1998 and use the obtained coefficients to construct the predicted values of likelihood of IPO laddering for 1999-2000 period. We find that there is a significant relation between predicted values of laddering and actual laddering - the correlation stands at 62.16\%. Moreover, 15 (28) of top 15 (30) companies with highest likelihood of laddering have actually been sued for laddering subsequently. This provides in-sample validation of our predictive model.

Also, if we relate the probability of being laddered to some of the observable characteristics that define the economics of laddering - trading by insiders and involvement of underwriter - we see that the predicted laddered IPOs display patterns which resemble the characteristics of the firms which went public prior to 2001 and were sued for laddering. In Table 4.14, we show that firms that rank high on the predicted likelihood of laddering have much higher instances of insider trading, dollar volume of these transactions is higher and insider net trading behavior as measured by ISPI index is more heavily tilted toward net selling of company stocks. In particular, in $52.5 \%{ }^{1}$ of companies in the upper quartile of the likelihood of being insiders are net sellers within 90 days after the expiration of the lock-up. This compares to $38.5 \%, 28.2 \%$ and $33.6 \%$ for the second, third and fourth quartile. Similar results could be observed when we compare dollar volume or the number of transactions being executed. If we condition on at least 1.5 (2) transaction per week to take place, results are even more extreme: $28.8 \%(27.1 \%)$ of companies in the top quartile of the probability distribution of being laddered are net sellers within 90 days after lock-up expiration. This compares to $12 \%$ (11\%), 9.4\% (7.6\%), and $12 \%(6.9 \%)$ for the third, second, and bottom quartile respectively. The unconditional average (between 2001 and 2007) ranges at $38.2 \%$ for the same time interval and at $15.6 \%$ and $12.4 \%$, if we condition on weekly minimum transactions.

\footnotetext{
${ }^{1}$ Not reported in Table 4.15 but available upon request 


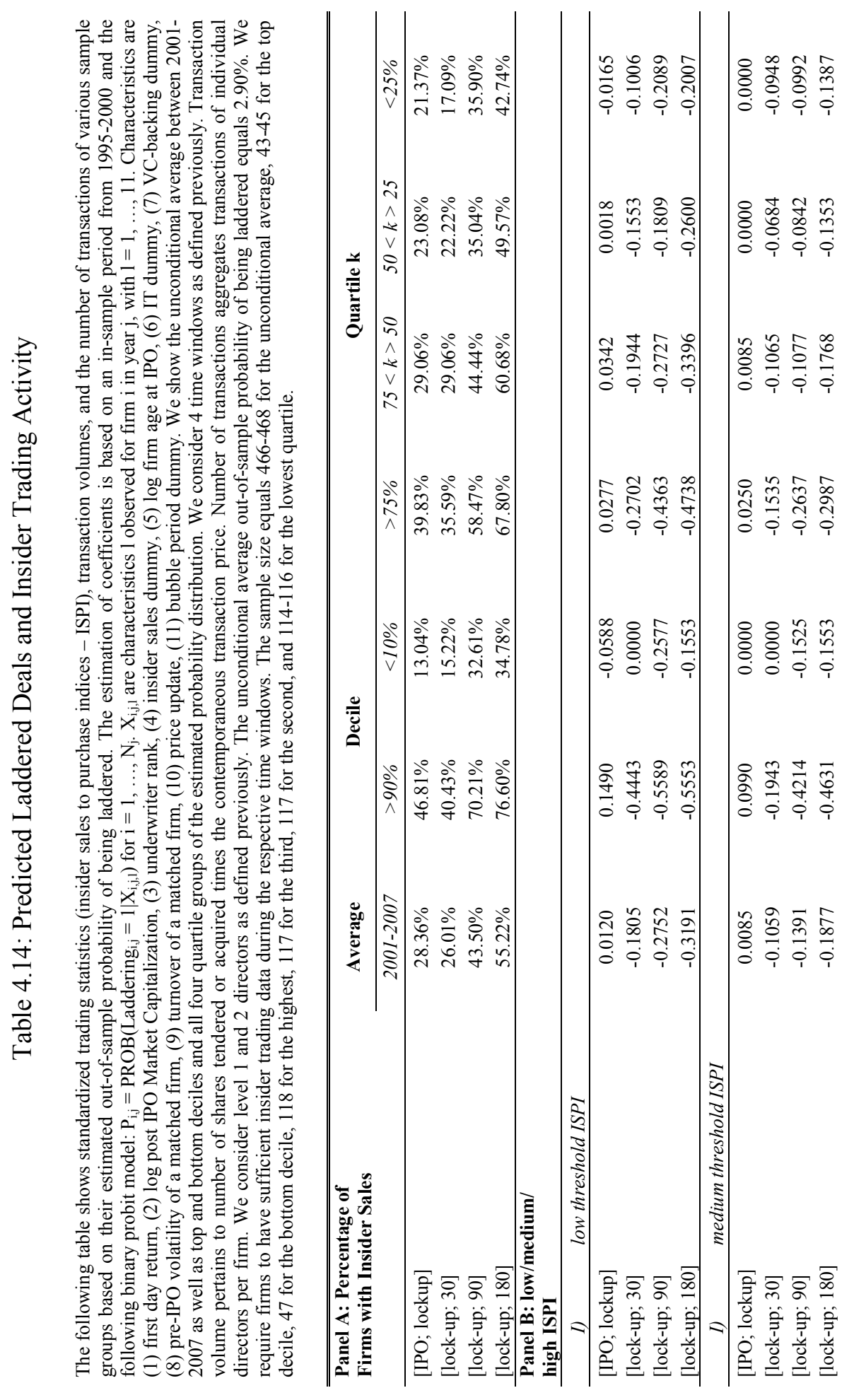




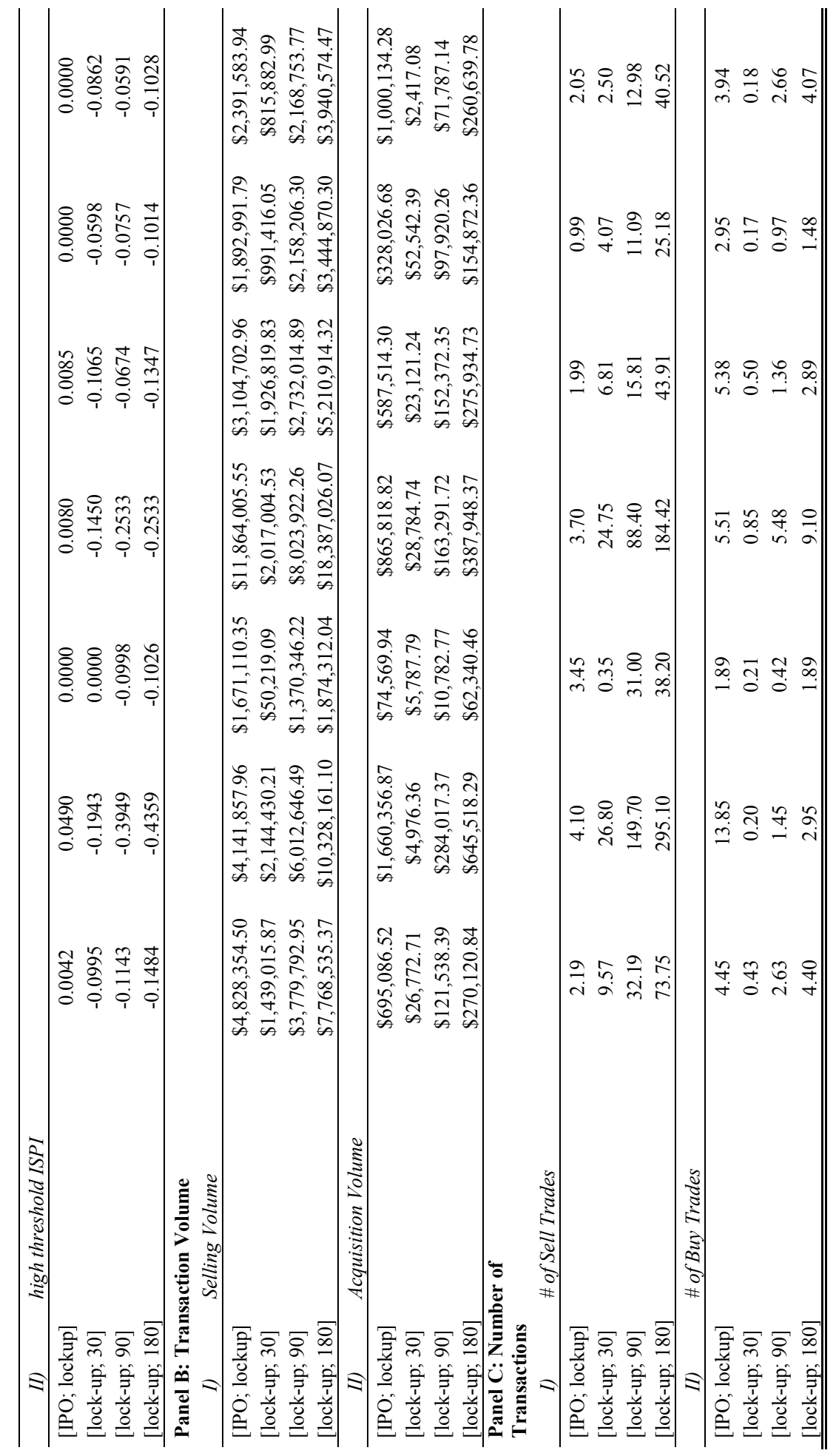




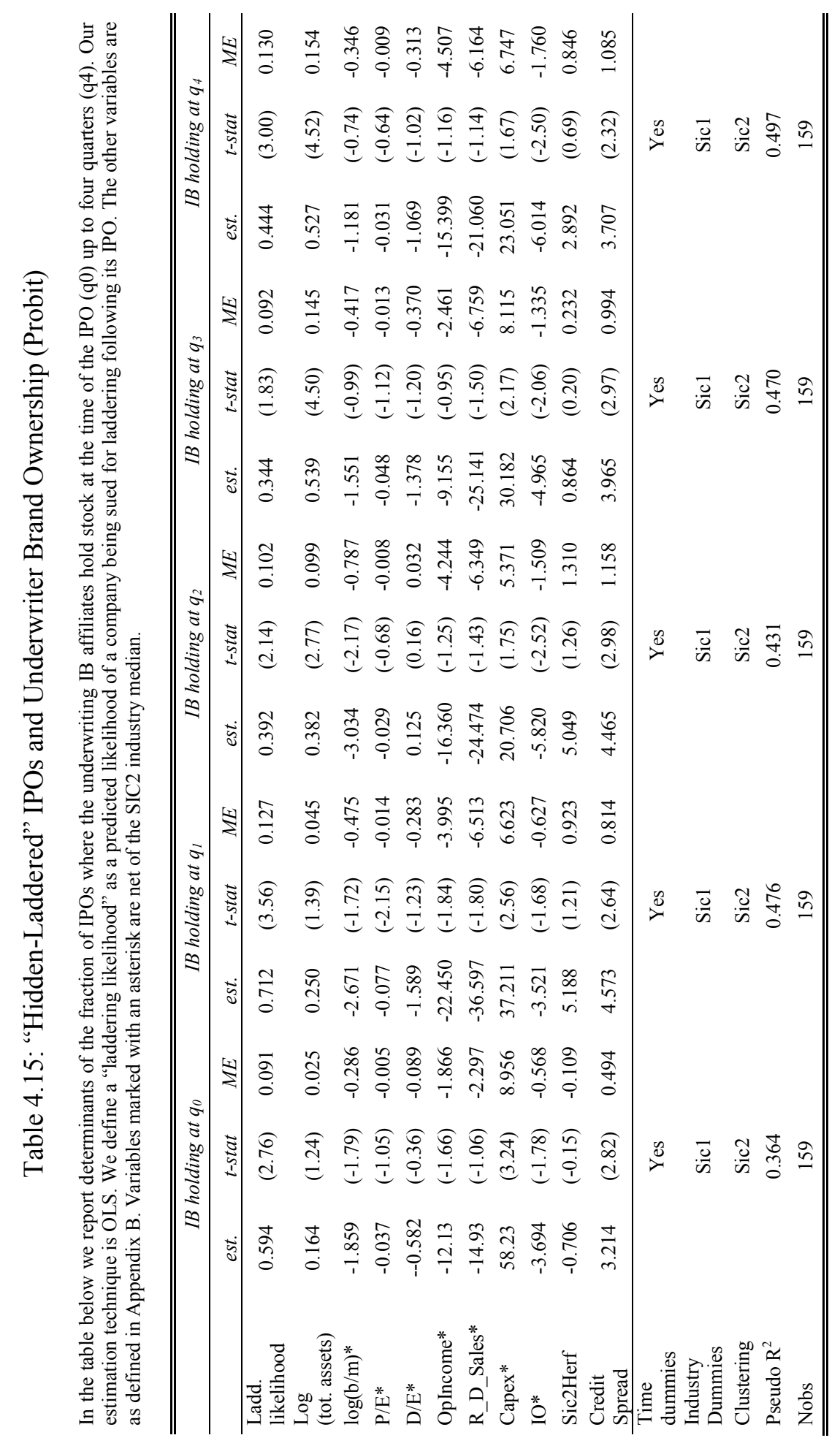


In Table 4.15, we relate the out-of-sample likelihood of laddering to brand underwriter ownership for the sample of IPOs in 2001-2007. In a multivariate setting we find that companies which are likely to have been laddered in this time period have a much more significant underwriter ownership than companies with low predicted likelihood of laddering. If we consider IPOs with a one standard deviation higher predicted laddering likelihood, then underwriter ownership in these companies in the quarter right after the IPO is $9.1 \%$ more likely and $12.7 \%(10.2 \%$, $9.2 \%, 13.0 \%$ ) one (two, three, four) quarter after. The difference in ownership is even more significant if we compare top quartile of laddering likelihood firms with firms in the third and fourth quartiles.

As additional check, we study the effects of insider selling after the IPO. Similar to the analysis in Section 5.2 we estimate abnormal stock performance of IPO firms around sales by insiders and relate them to the likelihood of laddering. As before, we define the abnormal return as the cumulative return on the company stock less return on the return on the company over the control window. The results indicate that there is no economic or statistical difference in stock market reaction to insider sales across laddering likelihood groups. This holds if we consider a twoyear window after the IPO as well as if we focus on the pre-lock period sales only. All these results suggest that a phenomenon very similar to laddering is still taking place and the regulatory changes just made it more difficult for investor to file lawsuits.

\subsection{Conclusion}

We study the effect of regulation on financial markets using the case of "laddered IPOs". In 2001, authorities deliberately started to clamp down on laddering and changed the degree of enforcement of Regulation M, which was amended in 1997 to proscribe market manipulation. In the period 1998-2000, a yearly average 104 of lawsuits were filed, which almost completely vanished after 2001. We argue that this sharp reduction, far from being the outcome or a successful regulatory sweep, in fact was due to the investment banks changing the form of the game. In fact, laddering still goes on with the same characteristics, but largely unnoticed by the Courts and investors.

To make this point, we first identify the drivers of laddering. We document the relation between laddering and underpricing and show that in the presence of lawsuits, underwriters used the first-day price return to avoid the probability of being sued. However, ex post, the likelihood of litigation was higher than ex ante, which is why underpricing was not optimal. We document a positive correlation between laddering and underpricing. Next, we provide evidence of how the underwriter can implement laddering. We argue that the underwriter exploits the 
asset management arm of the financial conglomerate it belongs to in order to support the price after the IPO. We compare laddered IPOs to a matched sample of other similar but non-laddered IPOs and we show that in the laddered IPOs, the probability of the affiliated conglomerate to have a stake is significantly higher (up to twice as high) compared to non-sued IPOs or laddered firms. Being laddered raises the fraction held by the affiliated underwriting group. In particular, laddered IPOs are $11.4 \%$ more likely to enjoy a direct investment of the affiliated conglomerate in the first quarter after the IPO, 9.1\% higher in the second quarter, $13.5 \%$ higher in the third quarter and $15.1 \%$ higher in the fourth quarter. No similar behavior is detected in case of non-laddered IPOs. A direct implication of this underwriter involvement is the fact that the performance of the laddered IPO is higher than that of other IPOs. Laddered firms display a better aftermarket performance in terms of raw excess returns than the non-laddered sample.

We then look at the potential beneficiaries of the laddering strategy and we identify them in the insiders. Laddering keeps the price artificially high so as to allow the insiders to trade by selling their share after the IPO and the expiration of the lock-up period without negatively affecting the stock price. Laddered IPOs display abnormal - with respect to the other IPOs and with respect to the average life of the stock - trading activity by the insiders as the lockup period expires. This higher trading activity by the insiders is not accompanied by higher price impact. The stock price reaction around insider sales is always lower for laddered IPOs than for the other ones. This holds across the different windows and is economically significant. For laddered IPOs the abnormal return is even lower than average.

We then ask whether this type of price support persists even after 2001, when no lawsuits were any longer filed. To address this issue, we use the characteristics that identify the laddered IPO in sample till 2000 and build a model that predicts laddering and we apply this model out-of-sample from 2001 onwards. We show that "hiddenly-laddered" IPOs display significant higher insider trading activity and a higher stake of the conglomerate affiliated with the underwriter. This trading takes place at convenient - in the sense of low price impact - trading conditions. 


\section{Appendix A: Variables used in the Analysis}

\begin{tabular}{|c|c|c|}
\hline Variable & Definition & source \\
\hline $\begin{array}{l}\text { Bookrunner(s) } \\
\text { rank }\end{array}$ & $\begin{array}{l}\text { Average rank of joint bookrunners (min. 1, max. 9) according to } \\
\text { underwriter reputation by Carter and Manaster (1990) }\end{array}$ & $\begin{array}{l}\text { SDC and Jay } \\
\text { Ritter }\end{array}$ \\
\hline $\begin{array}{l}\text { Bubble } \\
\text { dummy }\end{array}$ & $\begin{array}{l}\text { Time dummy equaling unity if IPO took place between } 1999 \text { and } \\
2000 \text {, zero otherwise }\end{array}$ & $\mathrm{SDC}$ \\
\hline firm age & logarithm of the IPO firm age at the date of the primary offering & Jay Ritter \\
\hline $\begin{array}{l}\text { first day } \\
\text { return }\end{array}$ & $\begin{array}{l}\text { change between the IPO offer price and the closing price on the stock's } \\
\text { first day of trading (i.e. IPO underpricing) }\end{array}$ & SDC and CRSP \\
\hline $\begin{array}{l}\text { internet/high- } \\
\text { tech IPO }\end{array}$ & $\begin{array}{l}\text { dummy equaling unity if IPO firm's primary SIC is classified as an } \\
\text { internet- or high-tech firm according to Ljungqvist and Wilhelm } \\
\text { (2003) and Loughran and Ritter (2004) }\end{array}$ & $\begin{array}{l}\text { SDC and Jay } \\
\text { Ritter }\end{array}$ \\
\hline $\begin{array}{l}\text { lawsuit filed } \\
\text { (dummy) }\end{array}$ & $\begin{array}{l}\text { dummy variable equaling one if the IPO firm was sued for "Section } \\
\text { 11-type" allegations or "laddering-type" allegations }\end{array}$ & $\begin{array}{l}\text { Stanford Law } \\
\text { School }\end{array}$ \\
\hline $\begin{array}{l}\text { Section } 11 \\
\text { (dummy) }\end{array}$ & $\begin{array}{l}\text { dummy variable equaling one if the IPO firm was sued under Section } \\
11 \text { of the Securities Act of } 1933 \text { as in Lowry and Shu (2002) }\end{array}$ & $\begin{array}{l}\text { Stanford Law } \\
\text { School }\end{array}$ \\
\hline $\begin{array}{l}\text { Laddering } \\
\text { (dummy) }\end{array}$ & $\begin{array}{l}\text { dummy variable equaling one if the IPO firm was sued for allegations } \\
\text { of "laddering-practices" from the underwriting investment bank }\end{array}$ & $\begin{array}{l}\text { Stanford Law } \\
\text { School }\end{array}$ \\
\hline $\begin{array}{l}\text { Money left on } \\
\text { the table }\end{array}$ & $\begin{array}{l}\text { Equals the variable number of shares offered times the first day closing } \\
\text { price minus proceeds raised. }\end{array}$ & SDC and CRSP \\
\hline $\begin{array}{l}\text { Number of } \\
\text { bookrunners }\end{array}$ & Number of joint book-runners in an IPO deal & SDC \\
\hline $\begin{array}{l}\text { Post IPO } \\
\text { Market } \\
\text { Capitalization }\end{array}$ & $\begin{array}{l}\text { Post IPO Market Cap is the number of shares outstanding after the IPO } \\
\text { times the first day closing price }\end{array}$ & CRSP \\
\hline $\begin{array}{l}\text { post IPO } \\
\text { std.dev. }\end{array}$ & $\begin{array}{l}\text { the annualized standard deviation of stock returns over one year from } \\
\text { day } 22 \text { after the IPO }\end{array}$ & CRSP \\
\hline $\begin{array}{l}\text { post IPO } \\
\text { turnover }\end{array}$ & $\begin{array}{l}\text { equals }\left[1-\prod_{t}\left(1-\text { volume }_{\text {traded }} / \text { total }_{\text {share }}\right)\right] \text {, computed for the } \\
\text { year after the IPO }\end{array}$ & CRSP \\
\hline $\begin{array}{l}\text { pre-IPO } \\
\text { Std.dev. }\end{array}$ & $\begin{array}{l}\text { annualized volatility of a matched sample over the one year prior to the } \\
\text { IPO to proxy for the IPO firm's standard deviation and stock turnover }\end{array}$ & CRSP \\
\hline $\begin{array}{l}\text { pre-IPO } \\
\text { Turnover }\end{array}$ & $\begin{array}{l}\text { average stock turnover of a matched sample over the one year prior to } \\
\text { the IPO to proxy for the IPO firm's standard deviation and stock } \\
\text { turnover }\end{array}$ & CRSP \\
\hline Price update & $\begin{array}{l}\text { Price update equals the percentage change between the midpoint of the } \\
\text { file range and the offer price (partial adjustment; Hanley, 1993) }\end{array}$ & SDC and CRSP \\
\hline $\begin{array}{l}\text { Prior } \\
\text { NASDAQ } \\
\text { return }\end{array}$ & $\begin{array}{l}\text { equals the compounded value-weighted NASDAQ market return over } \\
\text { the } 15 \text { trading days prior to the IPO }\end{array}$ & CRSP \\
\hline syndicate size & $\begin{array}{l}\text { Total number of (joint-) bookrunners, co-managers, global } \\
\text { coordinators and syndicate members }\end{array}$ & $\mathrm{SDC}$ \\
\hline VC backing & $\begin{array}{l}\text { dummy variable, which equals unity if the firm was backed by a } \\
\text { venture capitalist (VC) prior to the IPO }\end{array}$ & $\mathrm{SDC}$ \\
\hline
\end{tabular}




\section{Appendix B: Variable Description}

Variables marked with * are computed net of the SIC2 industry median.

\begin{tabular}{|c|c|}
\hline Variable Name & description \\
\hline $\log$ (total assets) & Total Assets, Compustat item 6 \\
\hline $\log (b / m)^{*}$ & $\begin{array}{l}\text { Book to Market }(\mathrm{B} / \mathrm{M}) \text { is the ratio of debt to equity for the prior fiscal year } \\
\text { (COMPUSTAT items } 9 / 60 \text { ) }\end{array}$ \\
\hline $\mathrm{P} / \mathrm{E}^{*}$ & $\begin{array}{l}\text { Price to Earnings }(\mathrm{P} / \mathrm{E}) \text { is the ratio of the year-end stock price to earnings per } \\
\text { share for the prior fiscal year (COMPUSTAT items } 24 / 58) \text {. }\end{array}$ \\
\hline $\mathrm{D} / \mathrm{E}^{*}$ & $\begin{array}{l}\text { Debt to Equity (D/E) is the ratio of debt to equity for the prior fiscal year } \\
\text { (COMPUSTAT items } 9 / 60 \text { ) }\end{array}$ \\
\hline OpIncome* & Ratio of operating income to total assets: CCM data $13 /$ data 6. \\
\hline R_D_Sales* & $\begin{array}{l}\text { Ratio of research and development expenses relative to total sales of the firm: } \\
\text { CCM data } 46 \text { / data } 12\end{array}$ \\
\hline Capex* & Ratio of capital expenditure to total assets of the firm: CCM data 128/ data 6 . \\
\hline $\mathrm{IO}^{*}$ & $\begin{array}{l}\text { End of the year fraction of shares outstanding owned by institutional fund } \\
\text { managers: Spectrum 13f. }\end{array}$ \\
\hline Sic2Herf & $\begin{array}{l}\text { Sum of the squared market share of each firm in the same industry during a } \\
\text { year. Market share is defined as the total sales of the firm in a given year } \\
\text { divided by the total sales of the industry in the year. The industry is defined at } \\
\text { the two-digit SIC code level, where the SIC codes have been obtained from } \\
\text { CRSP Monthly Stocks (SICCD). The sales data comes from CCM: data } 12 \text {. }\end{array}$ \\
\hline Credit spread & $\begin{array}{l}\text { Difference between yields to maturity on corporate bond and Treasury with } \\
\text { similar maturity: estimated from Lehman Brothers Bond Database data and } \\
\text { FRED }\end{array}$ \\
\hline
\end{tabular}





\section{Chapter 5}

\section{Industry competition, ownership structure and shareholder activism ${ }^{1}$}

We study shareholder activism by means of proxy proposals in the United States from 1997 to 2006. Using a new dataset of 9,082 shareholder proposals, we investigate the determinants of being targeted by shareholder activists and the corresponding voting results. Our dataset is distinctive from others as it also includes withdrawn and omitted shareholder proposals. By including those proposals in our analyses, we circumvent a selection bias towards only those proposals that actually go to a vote. We hypothesize that a lack of industry competition in combination with higher managerial entrenchment by fewer shareholder rights increases the likelihood of being targeted. Our empirical results support this hypothesis. Concerning the actual voting outcomes of shareholder proposals, we find that insiders' equity holdings are significantly and negatively correlated with the voting outcomes. Managers of firms that are operating in highly concentrated industries with few shareholder rights actively vote against shareholder proposals.

\section{$5.1 \quad$ Introduction}

We demonstrate that entrenchment and the firm's exposure to the degree of industry competition jointly influence the occurrence and efficiency of shareholder activism in the form of proxy proposals. Using this channel, shareholders can monitor and pressure management and boards to pursue actions that increase firm value and in turn supposedly lead to improved shareholder value. This is an important corporate governance mechanism in the United States. Rule 14a-8 of the Securities Exchange Act of 1934, the so-called shareholder proposal rule, allows individuals and institutional investors to file proposals to be included in the proxy statement that strive for a change in the companies' operations, governance

\footnotetext{
${ }^{1}$ This chapter is based on Bauer, Braun, and Viehs (2010).
} 
structures or social policies. We hypothesize that firms with low competition and weak governance are more likely to be targeted by shareholders. Concerning the success rate of the voting process, the roles of the outside shareholder base and insider holdings of voting rights are pivotal. Our study does not only investigate the magnitude and frequency but also the actual outcome of shareholder proposals.

The extent of shareholder activism has been increasing. Both small individual shareholders, so-called gadfly investors, and institutional shareholders are becoming more active in trying to influence and change managerial actions and corporate governance structures. Examples are Carl Icahn and his confrontational request to remove the entire board of directors of Yahoo! in 2008 or the Rockefeller family who strived for the separation of the positions of the chairman of the board and the CEO at Exxon Mobile in spring 2008.

Managers are exposed to several monitoring mechanisms. Firstly, the managerial labor market is designed to ensure that they maximize firm value. The extent to which managers are exposed to takeover threats and the accompanying shareholder wealth effects have been widely researched in the literature (cf. Gompers, Ishii and Metrick, 2003). Secondly, these insights have been extended by the degree of industry competition acting as an alternative or complimentary corporate governance mechanism in motivating and disciplining managers to exert optimal effort (cf. Hart, 1993, Giroud and Mueller, 2009; 2010). Industry competition as a governance device makes economic sense since competition in the industry reduces managerial slack and room for opportunistic behavior. We therefore assume the threat to be driven out of business to be equivalent to being taken over. Both eventually result in the manager's position to be endangered. Industry competition as a purely exogenous governance mechanism cannot be altered by shareholders. This implies that shareholder activism is more likely to occur in industries where the firm competes with very few companies for market share. We define competition as the Herfindahl-Hirschman Index (sum of each firms' squared percentages of the industry's total revenue; henceforth HHI) corresponding three digit SIC code.

We posit that if both industry competition and the managerial labor market fail to discipline managers, shareholders will adopt a different way of trying to influence managerial behavior and corporate governance structures, namely voice engagement through proxy proposals. By raising their voice, shareholders can prevent managers from enjoying a quiet life, a concept which has been put forward by Bertrand and Mullainathan (2003). Our paper assumes that already the mere filing of shareholder proposals is costly for managers to deal with. On the one hand this is due to negative publicity. For the manager this is a public signal for underperformance. On the other hand it also resembles a significant opportunity cost 
for managers to deal with and actively block proposals. This costliness also siphons resources and time from the annual general meeting agenda. This makes shareholder activism a pervasive nuisance for the entrenched manager. We argue that the occurrence of shareholder proposals is particularly strong for poorly governed firms that are not exposed to fierce industry competition and the managerial takeover market. In the absence of punishment for poor performance, shareholders' optimal response in these firms is to propose steeper incentives for managers. Figuratively speaking, the absence of "sticks", requires managers to be awarded "carrots" in order to exert optimal effort. However, carrots in the form of option packages involve the downside of equity compensation. As a result, corporate insiders might own a larger fraction of voting rights, which could be abused to enforce certain corporate policies that are not in the interest of shareholders. Consequently, we also investigate in how far insiders' voting rights influence the voting outcomes of shareholder proposals. More specifically, we study whether managers use their voting rights to vote against shareholder proposals.

We start by showing who gets targeted. First, we observe an increasing trend of shareholder proposals between 1997 and 2006 on aggregate. Secondly, companies are more likely to receive shareholder proposals if they are both poorly governed and if the disciplining force of a highly competitive industry is absent. This finding is particularly strong for shareholder proposals that pertain to internal governance and compensation, which is in line with shareholders' optimal response. Thirdly, the outside shareholder base and its structure play a significant role with respect to the occurrence and frequency of shareholder proposals.

Next we look at what affects whether activism is successful, i.e. how this depends on insider ownership and institutional ownership. Our analysis of the voting outcomes of shareholder proposals shows that shareholdings of corporate insiders are stronger correlated with the voting outcomes than holdings of outside investors. Insiders of firms, where both shareholder rights and industry competition are absent, apparently use their voting rights to block shareholder proposals. We find a significantly negative relation between our measure for insider ownership and the number of votes cast in favor of proposals. This result is robust to different measures of competition and governance quality. These findings indicate that managers in these firms are not able to shirk because corporate insiders receive negative publicity from activism and have to actively vote against proposals. This holds especially in the presence of steeper incentives. We argue that shareholders of poorly governed firms recognize that managers of those companies have more discretion and thus shareholders use "voice" engagement in the form of proxy proposals to discipline and monitor managers. 
Our results have several implications. If corporate insiders actively vote to block shareholder proposals, our results help to explain why previous studies find that the proxy proposal mechanism is ineffective in monitoring managers. The results of our empirical analysis ultimately relate to two different streams of literature on (1) shareholder activism and (2) industry competition as an alternative or complimentary corporate governance mechanism. To the best of our knowledge, no previous study explicitly investigates the impact of industry competition in combination with managerial entrenchment on the presence and effectiveness of shareholder activism. So far literature on shareholder activism has mainly focused on firm and ownership characteristics to draw inferences about the determinants of the likelihood of receiving a proposal and the corresponding voting results. In particular, the insider and outsider shareholder base influences the voting results of shareholder proposals (Gordon and Pound, 1993; John and Klein, 1995; and Gillan and Starks, 2000). Furthermore, the chances of being targeted by proposals are affected by the firm's past performance and its size (John and Klein, 1995 and Karpoff, Malatesta and Walkling, 1996). Previous studies find no significant relation between the insider holdings of voting rights and the likelihood of receiving a proposal.

Institutional shareholders play an important role in the proxy proposal process both as proposal sponsors and as shareholders per se (Smith, 1996, Wahal, 1996, Kahn and Winton, 1998, Gillan and Starks, 2000). These investors have more incentives and power to induce other (institutional) shareholders to vote with them. Consequently, proposals sponsored by institutions display the strongest voting support. They are also more effective when it comes to private negotiations with management which might eventually lead to changes in corporate policies or governance structures (Carleton, Nelson and Weisbach, 1998 and Chidambaran and Woidtke, 1999). Especially proposals that have been withdrawn prior to the annual meeting because of private negotiations provide evidence of bargaining power of institutional investors and/or management. Withdrawn proposals also reflect management's ability to shirk since it will negotiate about a possible withdrawal if it feels that those proposals erode managerial power or expose managers to negative publicity. Given that managers are able to successfully negotiate about a proposal withdrawal, they are in a comfortable position. Omitting these proposals from the analysis causes a serious bias towards ex post unsuccessful proposals, which we address.

An emerging body of literature questions the absolute measure of corporate governance and proposes the addition of a moderating factor into the analysis, namely the degree of industry competition. Theoretical work by Hart (1993) provides the foundation for the argument that industry competition can mitigate principal-agent conflicts. The key notion in this concept is that good governance 
only matters relatively to industry- or geographic peers. Giroud and Mueller (2010) report that highly concentrated industries benefit from good corporate governance practices whereas in competitive industries this effect is not observable. Likewise, Giroud and Mueller (2009) show that on average, firms in highly concentrated industries suffer from exogenous shocks that weaken governance structures of firms. In contrast, firms in highly competitive industries are not affected by these shocks. Further, they find that managers of firms in highly concentrated industries can enjoy a quiet life. Lastly, a firm's governance quality has to be evaluated against its operating environment (John and Kadyrzhanova, 2008). Ultimately, the evidence on industry competition as a governance mechanism alludes to a relation between the level of competition and the corporate governance quality of firms. We provide direct evidence on relative governance by showing that managers of poorlygoverned firms in highly concentrated industries are prevented from exerting no effort as shareholders become active and exert control. We show that only if managers hold substantial fractions of voting rights and they use those rights to vote against shareholder proposals, they are in a dominant position. A logical reaction is to exploit the voting rights in management proposals. However, shareholders are still able to attach negative publicity to their activism, which is what management aims to avoid.

Our paper contributes to the existing literature in numerous ways. Firstly, we examine the determinants of being targeted by shareholder proposals. Here, we contribute by studying the joint effects of industry competition and the managerial labor market (i.e. antitakeover provisions) on the occurrence of proposals. Our second contribution is to study under which circumstances corporate insiders are in a comfortable position when the disciplining forces from the takeover market and industry are absent. To shed light on this hypothesis, we study if insider holdings of voting rights are used to block shareholder proposals that eventually go to a vote at annual general meetings. If insider holdings of voting rights significantly relate to the voting outcome, we provide indicative evidence of managers that actively vote against shareholder proposals. However, if shareholders succeed at annual meetings with their resolutions, we argue find evidence of optimal contracting, and managers are still controlled. We therefore provide evidence on the efficiency of shareholder activism in the presence of insider holdings conditional on the firm's competitiveand governance environment. Our third contribution is the uniqueness of our data. Our shareholder proposal database includes shareholder proposal information from 1997-2006. This database is distinctive from others because it also includes information about withdrawn and omitted shareholder proposals. Withdrawn proposals have been subject to private negotiations between corporate managers and proposal sponsors prior to the annual meeting. Eventually, they are withdrawn from the voting process. Omitted proposals, on the other hand, have been removed from the voting agenda because they violate SEC regulations. In other words, these 
proposals are not put to a vote but they still occur. Existing studies on shareholder proposals (see for example Gordon and Pound, 1993 or Gillan and Starks, 2000) suffer from a selection bias in the sense that they focus only on proposals which management admitted to the voting process. These proposals have a low ex ante probability of receiving a majority. Restricting the analysis to these instances neglects the bulk of firms, where no such proposal has been filed from the investor base. More importantly it neglects firms, where proposals have been withdrawn for private negotiation. Hence, we investigate all companies in the COMPUSTAT universe, which have complete financial and ownership information available, irrespective of whether they have been targeted or not to circumvent this selection bias. The results of our paper cast doubt on prior studies' conclusion of ineffective shareholder voting. Shareholder proposals do not have to be voted on successfully to be effective. In our setup, the mere filing of proposals is sufficient for preventing managerial entrenchment and can be regarded as effective.

The remainder of our paper is organized as follows. In the next section we present our economic model and hypotheses. Section three presents our data and data sources. In section four we present descriptive statistics about shareholder proposals and our sample firms. In section five we perform our empirical analyses. Section six discusses our results and concludes.

\subsection{Economic Framework and Testable Hypotheses}

We conjecture that two important governance mechanisms influence the occurrence of shareholder proposals and the associated voting outcomes. The first channel is exogenous in nature and cannot be changed by shareholders, namely the competitive environment a company is acting in. As a proxy for the competitiveness of the industry we use the industry concentration level as measured by the Herfindahl-Hirschman Index based on the 3-digit SIC code. As a second channel, we argue that the firm's governance quality determines a firm's vulnerability towards shareholder proposals. We use the firm's exposure to the takeover market as a proxy for the governance quality (i.e. the Governance Index as constructed by Gompers, Ishii and Metrick, 2003; henceforth G-index). A higher exposure to the takeover market lowers managerial entrenchment and increases the extent of shareholder rights. We follow Gompers, Ishii and Metrick (2003) and Giroud and Müller (2009) to classify companies as either "democratic" (G-index $\leq 5$ ) or "dictator" (G-index $\geq 14$ ) companies that are exposed to either a highly "competitive" or "concentrated" industry ${ }^{2}$.

\footnotetext{
${ }^{2}$ Gompers, Ishii and Metrick (2003) set up the G-index which comprises 24 antitakeover provisions (ATPs). The authors add one point for each ATP in place. They classify companies as "democratic" if the G-index is smaller or equal to 5. On the other hand, "dictator" firms are companies that have a G-index 
We develop an economic framework to derive our testable hypotheses. This two-dimensional theoretical model illustrates how industry competition and the level of managerial entrenchment jointly influence the probability of being targeted by shareholder proposals.

\section{Figure 5.1: Economic Model}

This figure shows the economic model, which provides the theoretical foundation for our paper. We distinguish firms along two dimensions: shareholder rights and the degree of industry competition it is part of. In particular, we investigate dictatorship firms (G-index $\geq 14)$ and democracy firms (G-index $\leq 5)$ operating in highly concentrated (top quintile of the industry Herfindahl-Hirschman index) or highly competitive industries (bottom quintile of the industry Herfindahl-Hirschman index). Depending on the number of punishing devices companies have in place ("sticks") the likelihood of being targeted by shareholder proposals varies. Most importantly, the upper right quadrant displays the highest likelihood of being targeted since other disciplining tools are absent.

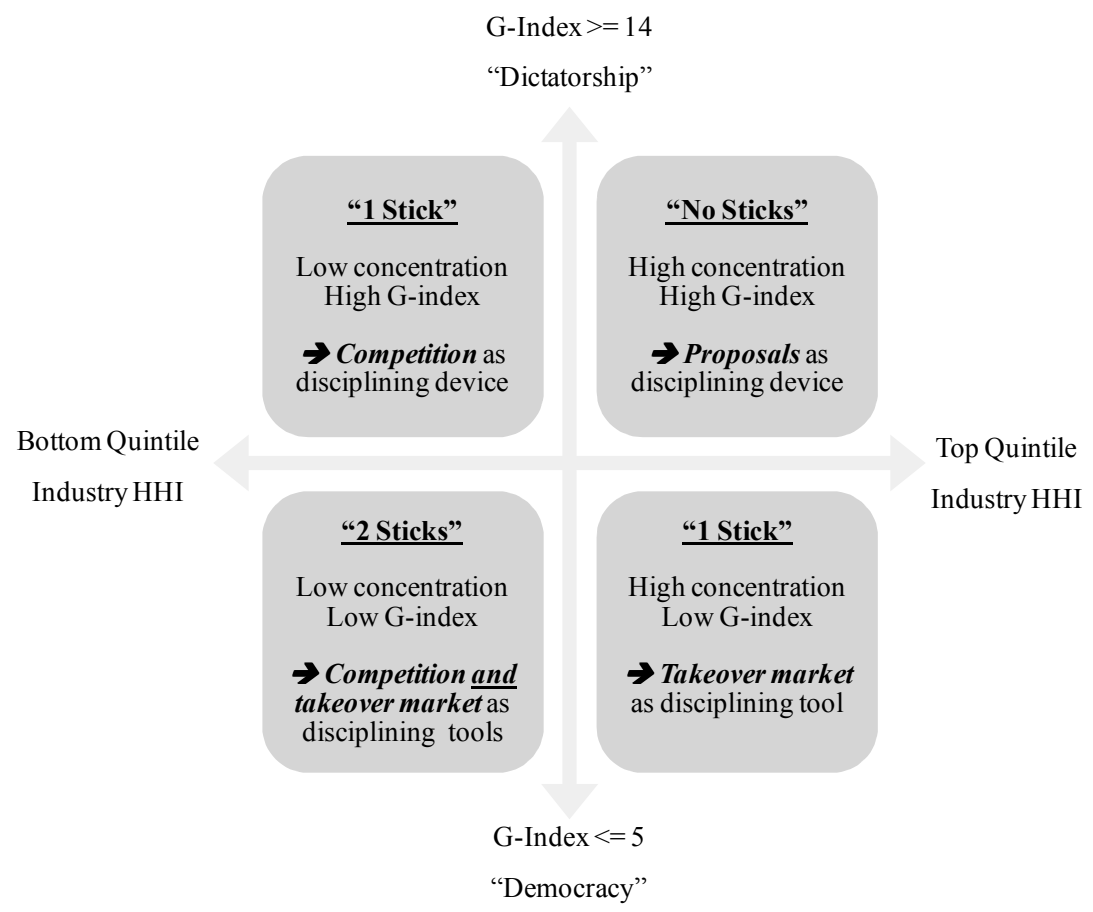

We follow Gompers, Ishii and Metrick (2003) and Giroud and Mueller (2009 and 2010) to classify companies as either "democratic" or "dictator" companies that are exposed to either a highly "competitive" or "concentrated"

larger or equal to 14. Firms are operating in a highly concentrated industry if the Herfindahl-Hirschman Index (HHI) of the respective SIC 3-digit industry belong to the highest quintile. Correspondingly, firms are part of a highly competitive industry if the HHI of the SIC 3-digit industry belongs to the lowest quintile. 
industry. Concerning our industry concentration measure, we adopt the same measure as Giroud and Mueller. Accordingly, industries in the top quintile with respect to the Herfindahl-Hirschman Index of the respective 3-digit SIC code are considered to be "highly concentrated". Correspondingly, industries in the lowest quintile of the Herfindahl-Hirschman Index are considered as "highly competitive" industries. Consequently, we differentiate between four different types of firms: dictatorship/concentrated industry (Q1: Poorly-governed firms), democracy/concentrated industry $(Q 2)$, democracy/competitive industry (Q3: Wellgoverned firms) and dictatorship/competitive industry (Q4).

Based on our model, we hypothesize the following. First, we hypothesize that firms in $Q 1$ are highly prone to shareholder proposals because those firms are lacking disciplining forces from both the takeover market and competition. Shareholders realize that managerial discretion is highest in those firms and decide to file proposals which call for a change in governance structures or incentive policies. In contrast, firms which belong to $Q 2$ or $Q 4$ exhibit relatively lower vulnerability towards shareholder proposals because in either case at least one governance mechanism is effectively present. Firms in $Q 3$ are least likely to be targeted by shareholders. The reason for this claim is that industry competition in this quadrant is high and those companies also exhibit more shareholder rights implying that both monitoring mechanisms are working properly, making it unnecessary for shareholders to file proposals. Hence, we conjecture:

H1: Firms with low shareholder rights and weak industry competition (Q1 firms) are more likely to receive shareholder proposals.

Firms located in the upper right quadrant should also exhibit steeper incentives in the form of option packages. This is because in the absence of punishing or disciplining devices from the takeover market and the industry, managers need to be given pecuniary incentives in the form of option incentives in order to exert effort:

H1a: Firms, which face little industry competition and have low shareholder rights, will have steeper incentives in the form of options than their well-governed counterparts. As a response, shareholders will file proposals on internal governance and compensation.

Thirdly, we posit that the outside shareholder base is an important determinant for the occurrence and frequency of shareholder proposals. The economic rationale is the following. A larger shareholder base - both in terms of the actual number of common shareholders as well as the density and structure of institutional shareholdings - increases the probability of one shareholder actually becoming active and file a proposal. Furthermore, if the ownership concentration 
among institutional shareholders is high as well, collusion between those shareholders occurs more easily. Correspondingly, we claim that the probability of being targeted with shareholder proposals increases with a concentrated institutional ownership and a larger shareholder base:

H1b: Higher institutional ownership concentration and a large shareholder base positively relate to the magnitude of filing shareholder proposals.

Concerning the voting outcomes of admitted shareholder proposals, we argue that the internal shareholder base is a key determinant. Implicit collusion for insiders is simple because they share common interests, objectives and incentives. We hypothesize insiders to be reluctant to accept intervention into the corporate strategy or governance structure and indicate a preference to entrench. Hence, we argue that insiders of firms in concentrated industries with strong takeover protection will exploit their holdings of voting rights in order to actively vote against shareholder proposals. Management's alternative to blocking shareholder proposals would be to propose compensation structures themselves via management proposals. In unreported tests on managerial-sponsored compensation proposals, we find that these proposals have an unconditional acceptance rate of more than $95 \%$.

H2: The voting outcomes of admitted shareholder proposals are negatively related to insiders' equity holdings.

\subsection{Data}

\subsubsection{Shareholder Proposals and Annual Meeting Information}

We use a unique dataset which provides information on all shareholder proposals brought forward to $S \& P 1500$ companies between 1997 and 2006 . The data come from RiskMetrics (formerly IRRC) and consist of annual meeting dates, information about the proposal content, proposal filers, proposal status and corresponding voting results. In total, our dataset includes 9,082 shareholder proposals addressing corporate governance and corporate social responsibility issues. These proposals have been put to a vote, have been withdrawn prior to the annual meeting for private negotiations, or they have been omitted from the proxy statement because they violate SEC proxy rules. We argue that previous studies suffer from a selection bias in that they neglect withdrawn and omitted shareholder proposals. We circumvent this bias because we include withdrawn and omitted proposals in our empirical analysis to study the actual probability of being targeted by shareholders. 
We manually classify both proposal topics and sponsors into different groups. The coarse classification is into four main categories: Corporate governance, corporate social responsibility (CSR), mixed issues and other proposals. In the following empirical analysis we focus on the former two categories only. Following Karpoff, Malatesta and Walkling (1996), Gillan and Starks (2000), Gompers, Ishii and Metrick (2003) and Becht, Bolton and Röell (2005), we break down corporate governance proposals into finer sub-classes. Corporate governance proposals consist of external corporate control proposals, internal governance proposals and takeover resolutions. External governance proposals mostly consist of resolutions related to anti-takeover devices and the market for corporate control in general. Most internal proposals deal with the board of directors, voting issues and executive compensation. Furthermore, we split up CSR proposals into social and environmental proposals, which deal with current buzzwords like human rights, health, diversity and climate change.

Furthermore, we distinguish between four different sponsor groups: Individual investors (e.g. Evelyn Davis, the Rossi Family, etc.), institutional investors (e.g. asset managers, investment companies, pension funds, etc.), coordinated activists (religious and other interest groups) and unions (e.g. AFL-CIO, Teamsters, United Brotherhood of Carpenters, etc.) as proposal sponsors. Appendix A contains examples of each proposal topic and sponsor category.

\subsubsection{Insider Ownership Data}

A cornerstone of our study concerns the ownership structure of our sample companies. We are interested in the fraction of voting rights owned by corporate insiders (i.e. the board) and whether these voting rights are used to block shareholder proposals at annual meetings. Pieces of insider ownership information come from RiskMetrics which include detailed director information and amounts of voting rights owned by each individual director. However, when two or even more directors have voting power over a set of stock owned by a trust, foundation, or another company, RiskMetrics assigns the corresponding voting rights to each director sitting on the board. This means, that the insider stock ownership sometimes exceeds $100 \%$ because of multiple assignment of the stakes. Hence, we recalculate the ownership data if the holdings exceed a pre-specified threshold of $80 \%$ using proxy statements of the relevant companies in order to get a more accurate measure of director holdings. We employ the following three-step methodology to recalculate insider stock ownership which is based on Hermalin and Weisbach (1991) and DeAngelo and DeAngelo (1985): (1) Shareholdings owned by a trust, foundation or another company are considered to be managerial holdings if directors and/or officers of the holding company are also sitting on the board of this particular company in which their company owns a stake; (2) To avoid double counting, we 
assign the ownership owned by a trust, foundation or company to only the director with the highest hierarchical position in the sample company; (3) In cases where the positions of the directors are unidentifiable, we attribute the stock ownership to only one director.

We then merge RiskMetrics' data with COMPUSTAT's Execucomp database to identify the incumbent CEO of the relevant companies. Following those steps we are able to calculate our proxies for insider holdings: Overall board ownership, the CEO holdings and the Herfindahl-Hirschman Index of the board's holdings of voting rights as a concentration measure of insider holdings.

\subsubsection{Shareholder Base Data}

Next to insider holdings of voting rights we are also interested in the effects of the outside ownership structure on both the occurrence of shareholder proposals and the outcomes of proposals that are put to a vote. We use Thomson Reuters 13(f) flings to retrieve data on the holdings of institutional investors and construct the following variables. We count the number of institutional $5 \%$ holders as well as the concentration of institutional ownership with the following measure:

$$
H H I_{j t}=\sum_{i=1}^{N_{j}} s_{i j t}^{2}
$$

where $H H I$ is the Herfindahl-Hirschman Index of percentages held by institutional investors (as designated by the Thomson Reuters institutional holdings 13f database) of firm $j$ in year $t$. We sum the squared percentages of each institutional investor $i$ at time $t$ across $N$ investors in firm $j$. We use the average of four quarterly filings per company and investor. Naturally, the index is bounded between zero and one. We further have a ratio of total institutional share ownership, which is common practice in the literature. The economic logic behind counting the number of institutional blockholders is that more large shareholders are either more likely to disagree or to collude over shareholder proposals depending on the proposal content and sponsor identity.

In addition to that we break down the institutional ownership structure further. Bushee (2008) has further sub-classified the Thomson Reuters database into eight distinct investor groups: (1) bank investors, (2) insurance companies, (3) independent investment advisors, (4) investment companies, (5) corporate pension plans, (6) public pension plans, (7) university funds and endowments, and (8) miscellaneous. Due to potential ambiguities we summarize group (3) and (4). We also compute the dollar values of the holdings in order to account for differences in market valuations and firm sizes. The economic intuition behind disaggregate institutional investor holdings is as follows. There are certain investor groups which 
are more likely to suffer from conflicts of interest and are subject to higher disagreement. Other investor groups, as for example corporate pension funds and insurance companies, tend to outsource their proxy voting and are likely to vote with the management recommendation possibly because of existing business ties with target companies (cf. Cornett et al., 2007 and Chen et al., 2007).

\subsubsection{Firm, Industry and Governance Characteristics}

We obtain relevant firm level data from COMPUSTAT. This data include information about the company's cash position, size, market-to-book ratio, dividend yield, past performance and leverage. We approximate firm age with the first listing date on CRSP. RiskMetrics is the source for the G-index, our measure for the governance quality, and the dual-class status of our sample firms. In our analyses we also control for managerial incentives. To do so, we use the "scaled wealthperformance sensitivity" developed by Edmans, Gabaix and Landier (2009). This variable takes into account that managerial effort is multiplicative with respect to firm size. It measures the CEO's wealth change (in U.S. dollars) for a percentage point change in firm value, irrespective of firm size and industry. To obtain a measure for the industry concentration level, we calculate the Herfindahl-Hirschman Index for every 3-digit SIC industry, based on all COMPUSTAT firms. We calculate the HHI by summing all squared market shares (based on total sales) of all firms in the respective 3-digit SIC industry.

\subsection{Descriptive Statistics}

\subsubsection{Shareholder Proposals over Time}

As our dataset covers the time period between 1997 and 2006 we can investigate the evolvement of shareholder activism over time. Figure II shows the number of proposals per year and per sponsor group over time. It also shows the average voting result in a given year. Several observations emerge from the evolution of proposals. Initially individual investors file by far the highest fraction of proposals, which gradually declines until 2006. Contemporaneously, activism by institutional investors has almost monotonically increased between 1997 and 2006. This result can be explained from a general increase in institutional ownership from 50 to over $70 \%$ during our sample period (cf. Gillan and Starks, 2007) in U.S. stock markets. Further striking findings are the sharp increase of filed proposals by union funds after the passage of the Sarbanes Oxley Act in 2002 and the seemingly reduced importance of coordinated activist groups over time. Concerning the success of proposals, we recognize a steady increase in average voting results, indicating that shareholder activism through proxy proposals became more successful. 


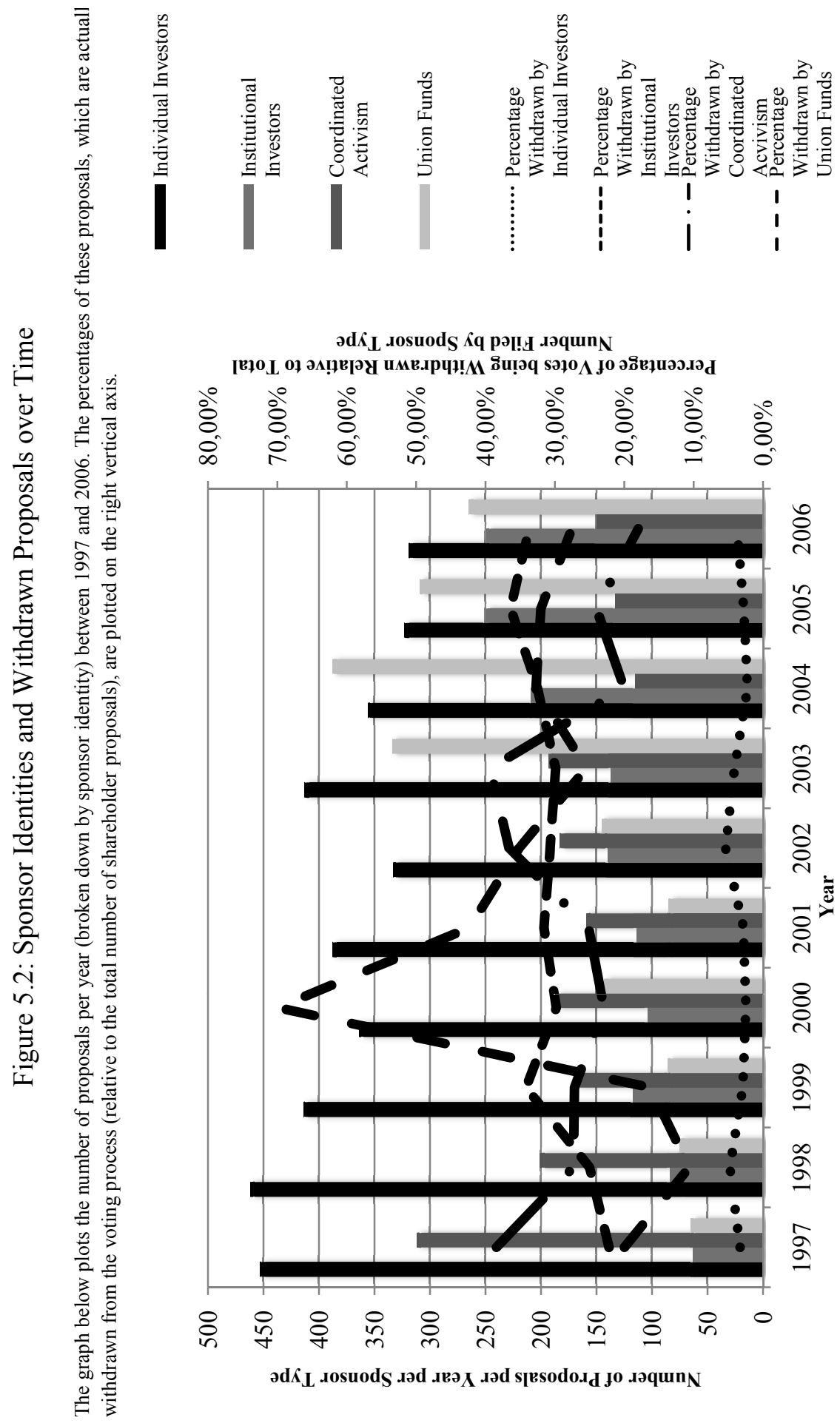




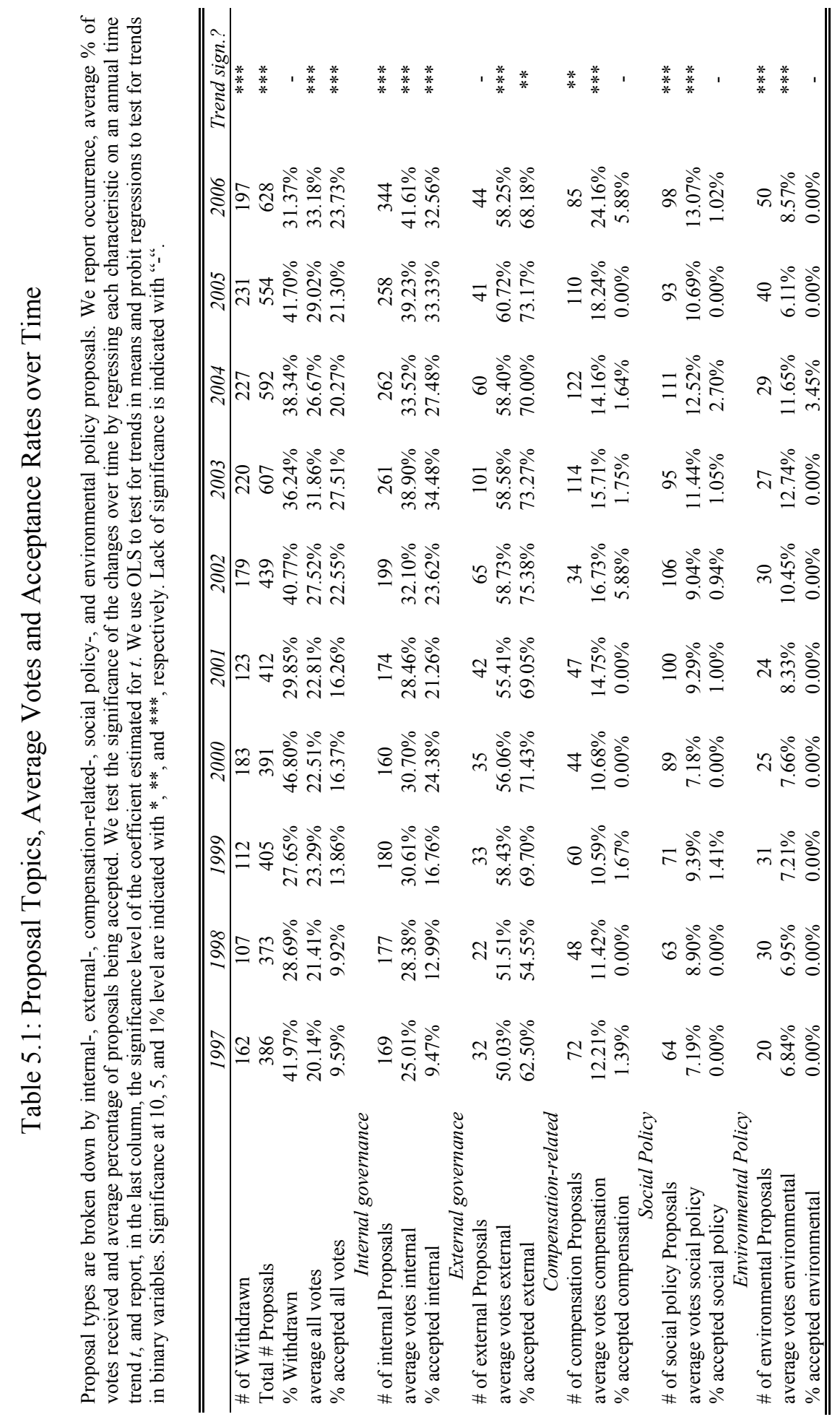


Investigating the voting results and success rates of the different subsets of shareholder proposals sheds further light on both the efficiency and effectiveness on shareholder activism. Eventually, proposals sponsored by individuals are less likely to be withdrawn from the actual voting process in contrast to institutional activism. The stems from the fact that institutional investors have more bargaining power in the negotiation process with management and insiders are more likely to have an incentive not to expose voting on e.g. takeover defenses. This result is also consistent with earlier research on negotiations on shareholder proposals (see for example Chidambaran and Woidtke, 1999). Further striking findings are the sharp increase of filed proposals by union funds after the passage of the Sarbanes Oxley Act in 2002. Moreover, these proposals also bear a remarkable withdrawal rate, which also points at strong bargaining positions of these types of investors. The significantly lower percentage of withdrawn proposals filed by individuals is either to be explained by their low ownership stake or by a tendency to pursue private objectives and to file frivolous proposals.

Aforementioned investor groups can file proposals of various types. We follow a coarse subdivision of proposal topics into governance and corporate social responsibility (CSR), a division commonly used in the literature (cf. Campbell, Gillan, and Niden, 1999). Focusing on the types of proposals being filed and their success rates sheds further light on both the efficiency and effectiveness on shareholder activism. We also test for significance of trends over time. The results can be seen in Table 5.1.

The number of withdrawn proposals increases over time. However, as the total number of observations increases disproportionately, we fail to observe a significant time trend. We observe the largest number of proposals from the area of internal governance. However, proposals with the highest success rate (both in terms of average votes in favor and fraction of proposals accepted) are those on external governance. This might be due to a higher awareness and the fact that takeover defenses are more pervasive and as such are easier to vote on since there is less disagreement. Even though the average percentage of votes in favor of compensation-related proposals has significantly increased (almost doubled) over time, only a tiny fraction eventually get accepted. This already gives a first indication of managerial preferences to set their own pay (Bertrand and Mullainathan, 2001, Bebchuk, Fried and Walker, 2002). The lower part of Table 5.1 shows that proposals on CSR (social- and environmental policy) only play a negligible role in terms of their effectiveness even though occurrence and frequency have increased over time. The low success rate might also be attributed to disagreement among shareholder groups and absent awareness among investors that CSR related proposals could affect shareholder wealth. 


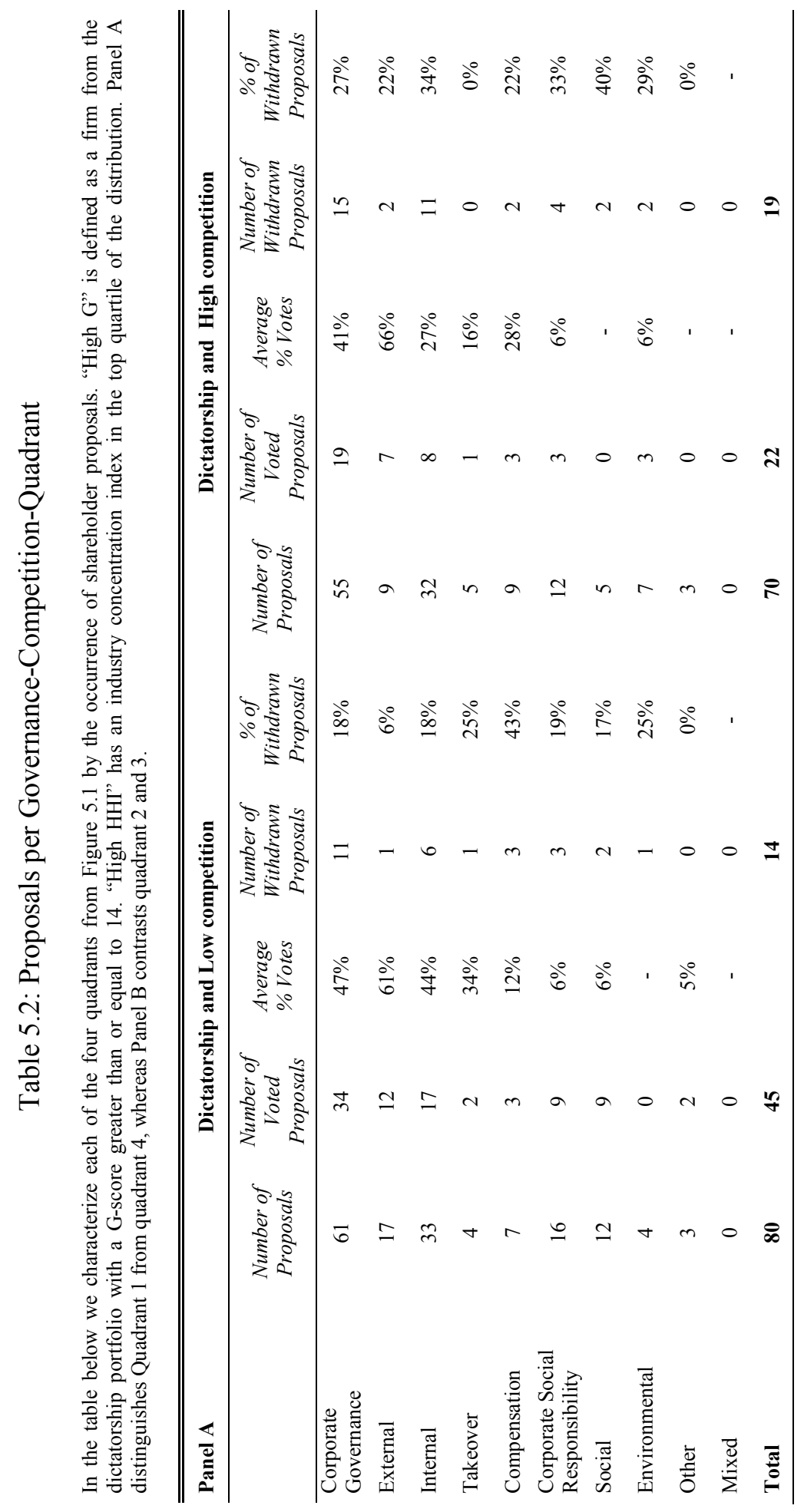

146 


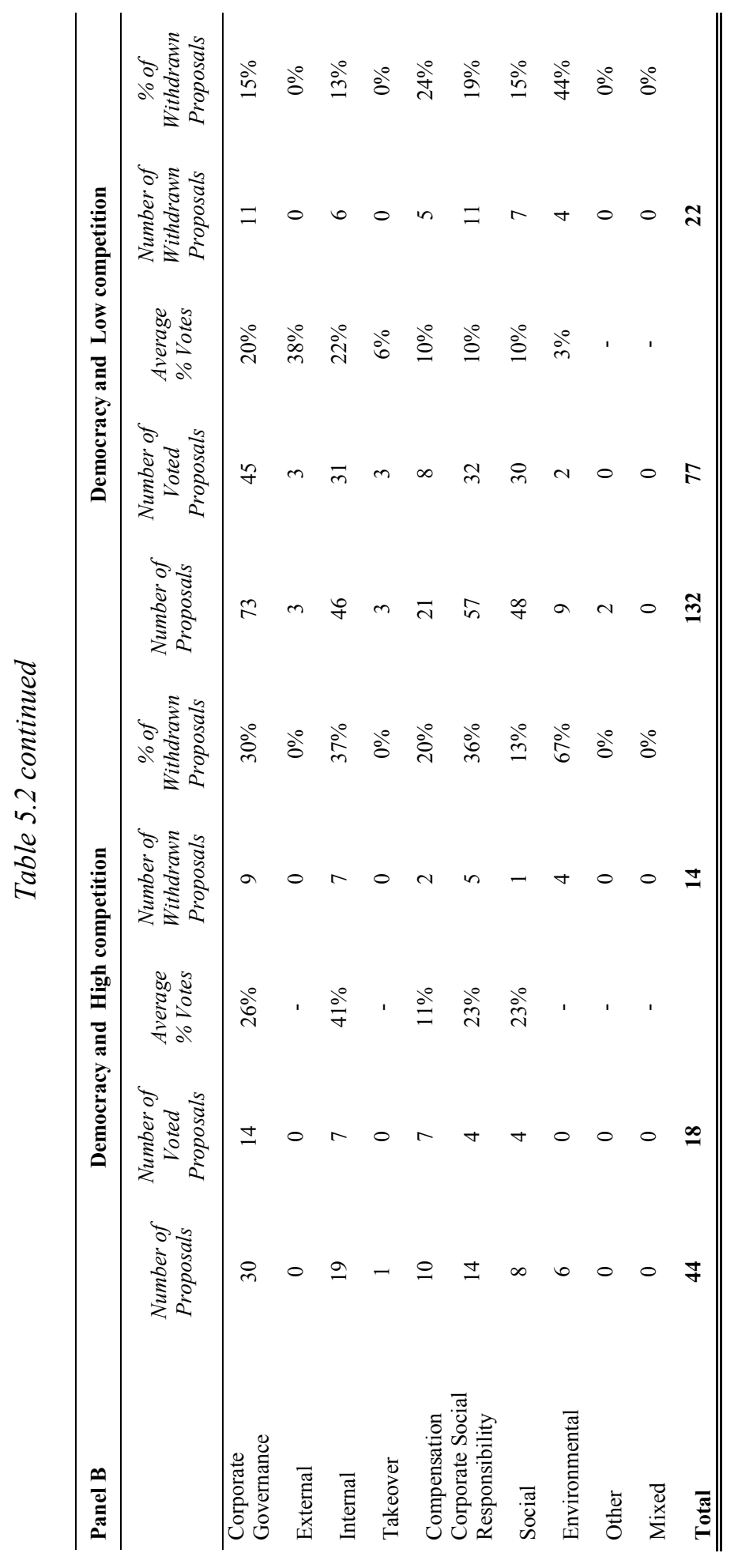




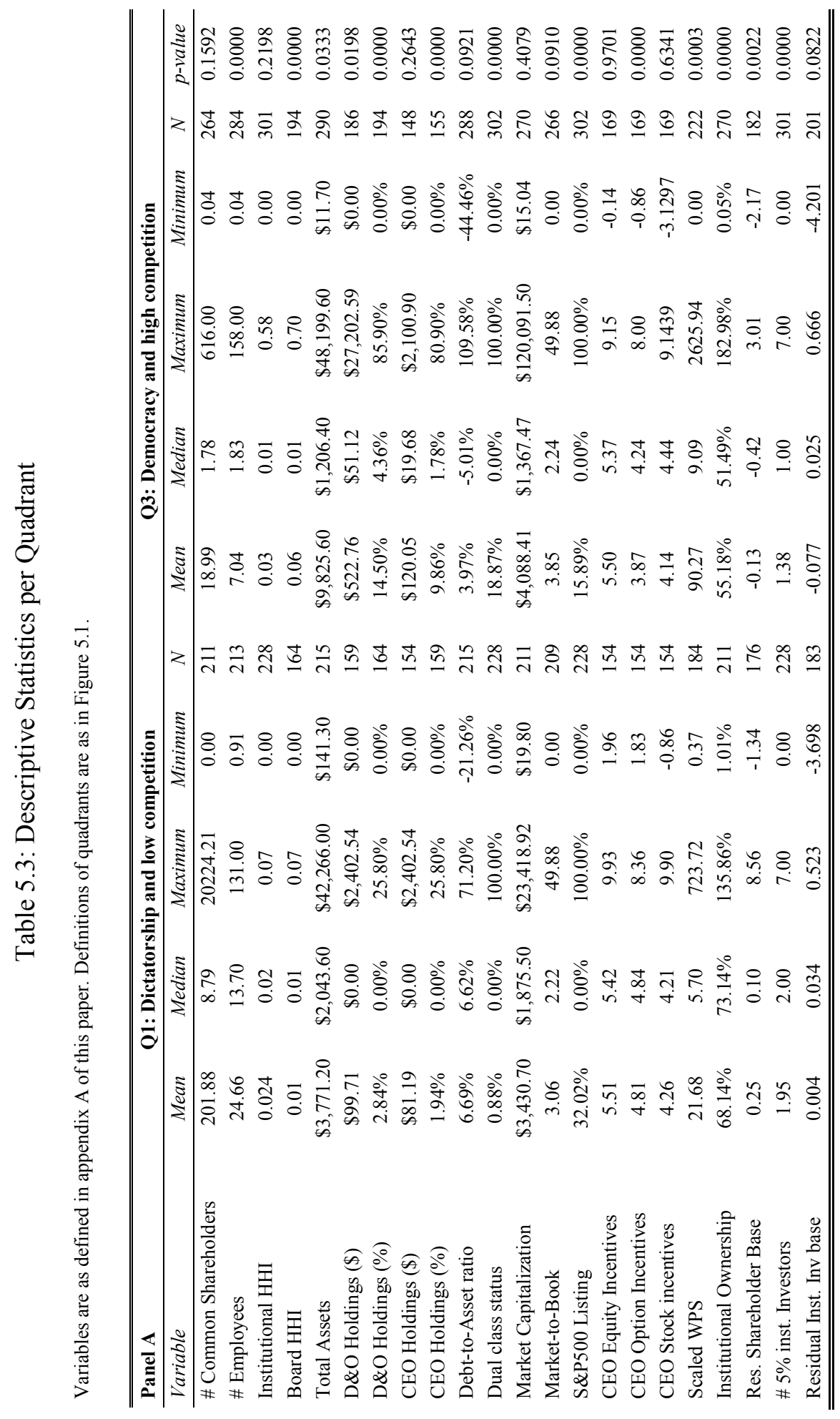




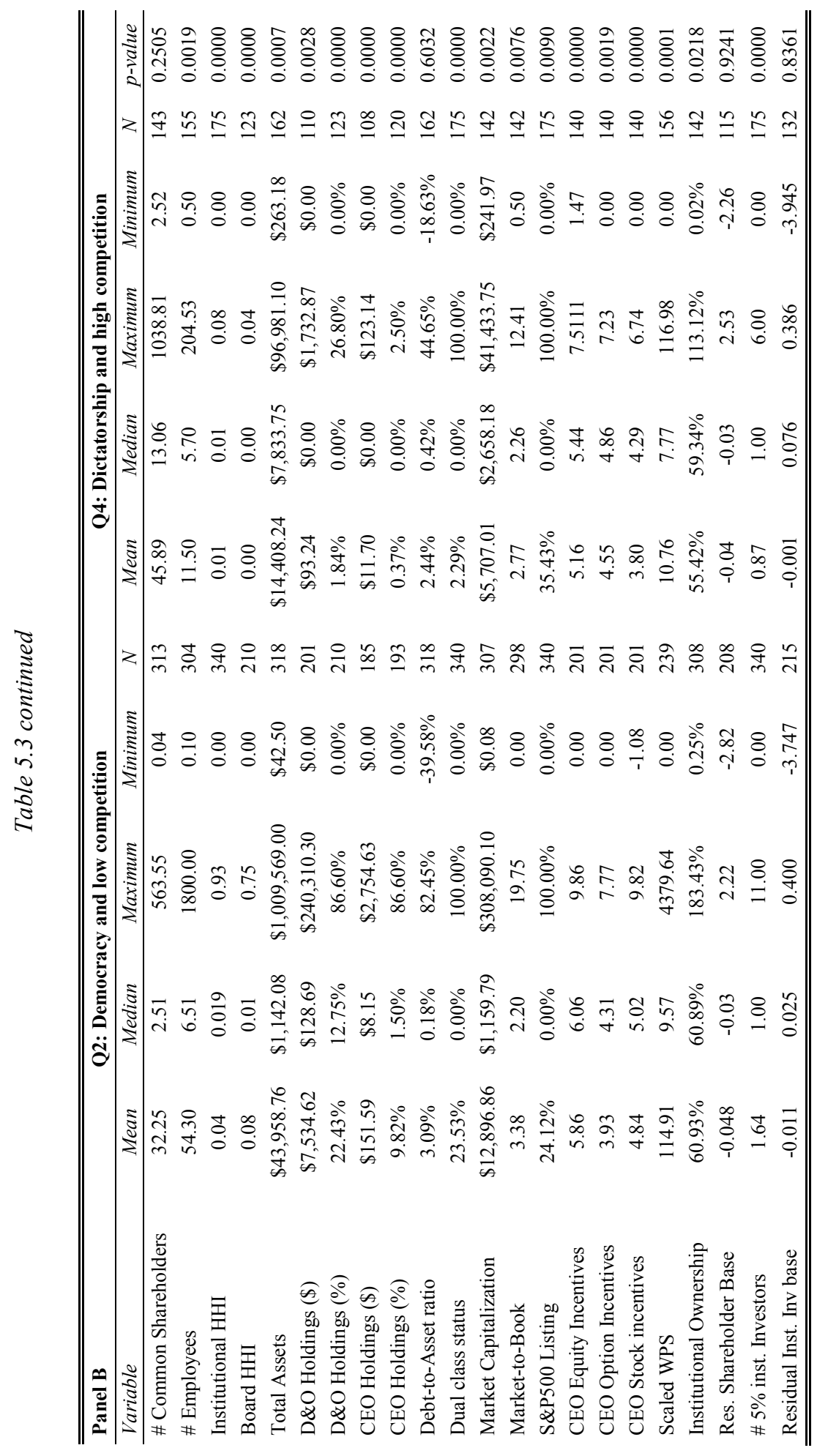




\subsubsection{Governance and Industry Competition}

We investigate four extreme samples based on their prevalent level of shareholder rights and industry competition. We provide preliminary evidence to our empirical predictions based on Figure 5.1. In the following we take a closer look both at proposal- and company characteristics per quadrant to check for patterns.

We note in Table 5.2 that there is the strongest occurrence of shareholder proposals in the quadrant with strong shareholder rights (a low G-Index) and high industry concentration (high HHI). This gives a first indication on whether shareholders experience activism via vote as a disciplining device or not. If they did, we would have expected to observe the majority of shareholder proposals to occur in the upper right quadrant (high G-Index and high HHI) of our economic model. In the first quadrant, which exhibits little shareholder rights and low competition a significant portion of compensation proposals are eventually withdrawn from the proxy forms. Remarkably, we also see that this quadrant also has the highest percentage of votes in favor of the proposal without controlling for other factors.

Turning to company-, stock-, and ownership characteristics of these four quadrants Table 5.3 sheds further light on the economic conditions for shareholder proposals to be successful. In Panel A we only compare the extreme groups of firms, i.e. the quadrant where both disciplining devices are absent with those firms where both competition and external governance are well-developed. Most striking differences between those two groups lie in the level of stock option incentives. Managers of poorly-governed firms ( $Q 1$ firms) have significantly more option incentives than well-governed firms. This is in line with the empirical predictions of our economic model in Figure 5.1 (Q3 firms). According to Hall and Liebman (1998) and Chapter 3 of this dissertation, remuneration in the form of stock options has become the dominant form of explicit incentives for CEOs. Moreover, important differences with respect to the ownership structure are the outside shareholder- and the institutional investor base. Surprisingly, firms in the extreme governance and competition quadrant hardly have a dual class status and are fairly similar in market capitalization. Institutional ownership is the highest in this quadrant just like the average number of institutional $5 \%$ blockholders. With respect to the inside ownership structures, we see that dictatorship firms in low competition industries do not hold larger fractions of company stock, neither in percentage nor in dollar terms. We acknowledge that the institutional investor base is not homogeneous and different investment strategies also determine the extent to which these owners become active. In the following subsection, we investigate in how far these differences with respect to the investor base and governance characteristics of firms contribute the presence and effectiveness of shareholder activism in the form of proxy proposals. 


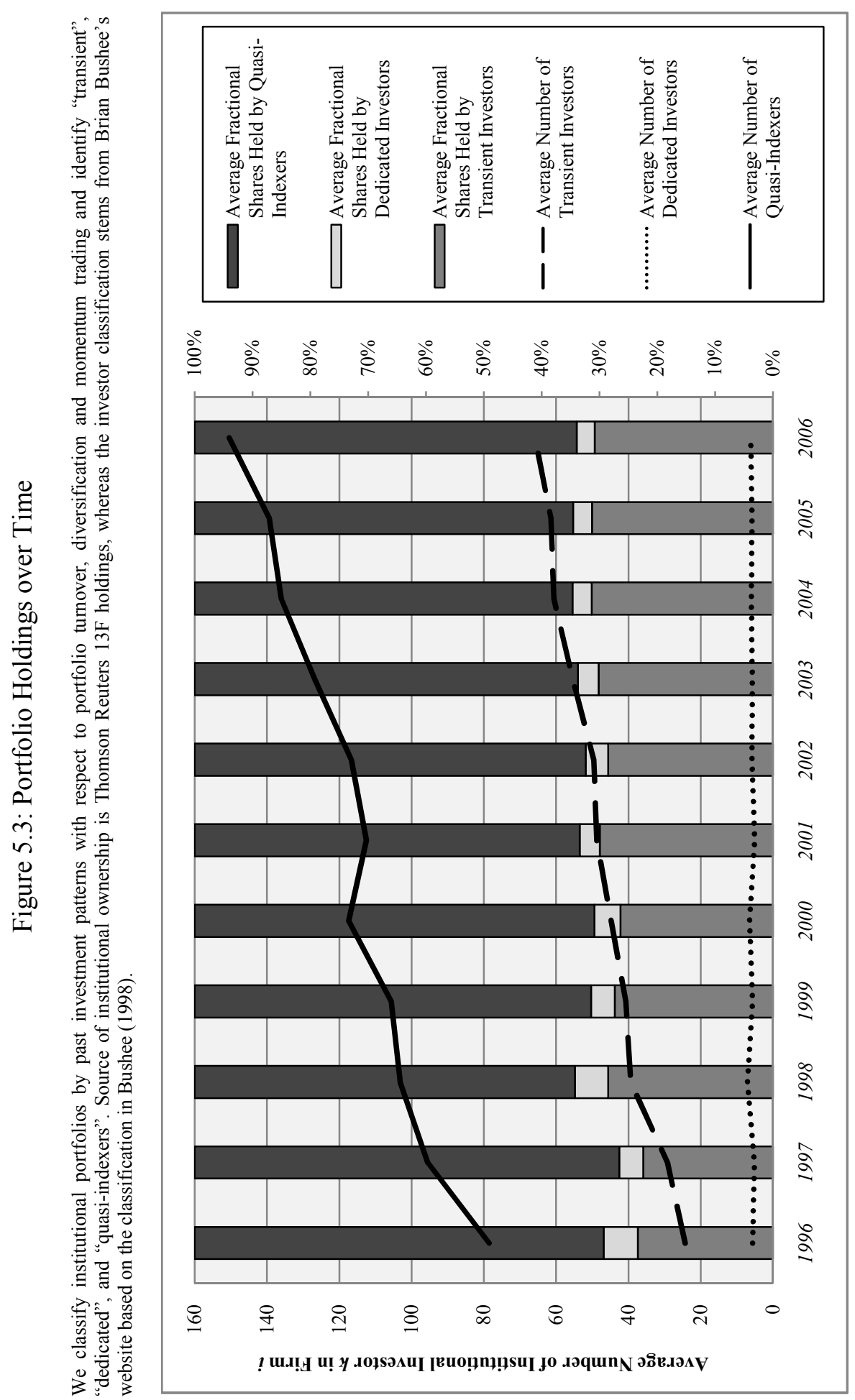




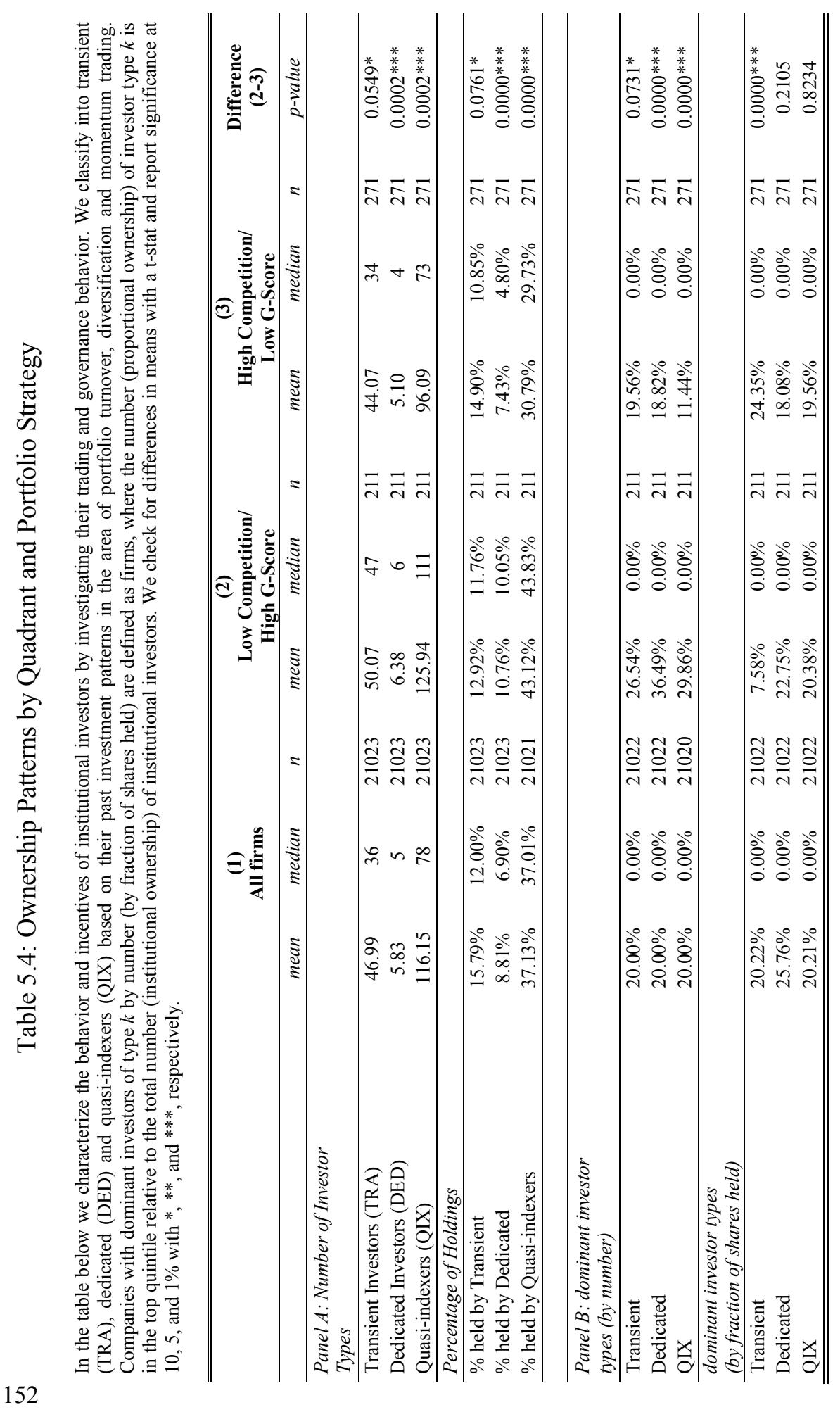




\subsubsection{The Heterogeneity of the Institutional Investor Base}

Institutional investors can be characterized and distinguished along their portfolio holdings and their investment strategies. We classify into transient (TRA), dedicated (DED) and quasi-indexers (QIX) based on their past investment patterns in the area of portfolio turnover, diversification and momentum trading. Investors from the TRA bracket hold small stakes in numerous firms and trade frequently basing their trades on signals.

DED investors have large, long-term holdings, which are concentrated in only few firms. These investors stem more from Japanese and German origins (Porter, 1992). QIX investors use buy-and-hold indexing strategies, which are characterized by a high degree of diversification and low portfolio turnover (Bushee, 1998). ${ }^{1}$ All of these institutions face a trade-off in enforcing either of the two governance mechanisms of "voice" and "exit". The shape and the extent of this trade-off hinges upon the size of the investor type's stake, the liquidity of the stock, the impounded effect of exit on stock prices and the expected costs of monitoring from free-riding of other investors. Under the assumption that "exit", "voice" and "no action" are the only available options of shareholder activism, we would expect that "transient" institutions are more likely to use "exit" rather than "voice". Its effectiveness on stock price is however mitigated by the small stakes that this investor group holds. By contrast, "dedicated" investors have stronger incentives to file shareholder proposals even though selling will depress share prices stronger because of large stakes. This is however mitigated by dedicated investors' long-term horizons. Their strength of activism by voice is further mitigated by concerns that other investor groups will free-ride on their monitoring effort (Admati and Pfleiderer, 2009). Lastly, quasi-indexers are in essence restricted from exit strategies due to exogenously given portfolio strategies and investment policies. Moreover, exit actions have a limited price impact due to small stakes and are therefore less credible as a disciplining and control device. Since these investors are broadly diversified they have to carefully evaluate and monitor their portfolios to screen for activism targets.

A closer look at Figure 5.3 confirms the result by Gillan and Starks (2007) of a steadily increasing institutional ownership in the U.S. Here, we further break down into the number of investor types and the fraction of institutional ownership by investor type $k$. The average number of quasi-indexers increases almost monotonously over time from less than 80 to over 150 . More than doubling in quantity, transient investors also become more dominant market players, whereas the role of dedicated investors remains fairly unchanged. Focusing on ownership by

\footnotetext{
${ }^{1}$ Please refer to http://accounting.wharton.upenn.edu/faculty/bushee/IIclass.html for more details.
} 
investor types, we see that the proportions shift more towards transient institutions. Still, the average fractional shares held by quasi-indexers constitute almost two thirds of total institutional ownership.

In Table 5.4 we present univariate analyses of our two extreme groups from Table 5.2 along the degree of external governance and industry competition. Several observations can be made. Unconditional on the governance-industry competition quadrant we confirm that quasi-indexers constitute by far the largest fraction of institutional ownership - both in terms of the number of investor type $k$ in the institutional investor base and in terms of the proportional holdings. If we subdivide groups into low (high) competition and high (low) score on external governance, we see that group 2 is held disproportionally by quasi-indexers and dedicated investors hold twice the proportional ownership in group 2. Panel B investigates the presence of dominant investor types. Most importantly we note that there are more transient institutions in group 2 however they surpass group 3 in terms of fraction of shares held. Group 2 is held disproportionally by quasi-indexers and dedicated investors. Given the fact transient investors only constitute a negligible fraction of proportional ownership in group 2, we would expect dedicated investors or quasi-indexers to become more active with voice due to their inability or unwillingness to follow the Wall Street Rule.

\subsection{Methodology and Empirical Results}

In this section we present our methodology of our empirical analyses and the corresponding empirical results. For the ongoing multivariate analysis, we restrict ourselves to a classification of investors by institutional type rather than the portfolio holdings and investment strategy from subsection 5.4.3. We do this to be more consistent in our second stage estimation. This is because we do not find a sound conceptual reason why investment strategies should be related to the outcome of shareholder proposals. Therefore we can use the same ownership structure variables in both regressions: the occurrence and magnitude and the outcome of shareholder proposals. ${ }^{2}$

\subsubsection{The Ownership Structure and Shareholder Activism}

\subsubsection{Determinants of the Shareholder Base and Structure}

We hypothesize that ownership concentration of insiders plays a more relevant role in voting outcomes than the outside shareholder structure. The

\footnotetext{
${ }^{2}$ For the sake of completeness we also ran the regressions with our TRA, DED, and QIX variables. Because the interpretation is more difficult and results are fairly weak in magnitude, we decided to suppress them.
} 
economic rationale behind this expected relation is the following. On the one hand, a larger shareholder base - both in terms of the actual number of common shareholders as well as the density and structure of institutional shareholdings increases the probability of one shareholder actually becoming active and file a proposal. On the other hand, this larger shareholder base also results in a higher likelihood of disagreement among shareholder groups and collusion becomes harder. Institutional blockholders are also unlikely to solve the collective action problem to overcome coordination obstacles since multiple blockholders will have multiple objectives and are more likely to disagree. By contrast, insiders have more common objectives and incentives. We hypothesize insiders to be reluctant to accept interventions into the corporate strategy or governance structure and indicate a preference to shirk or exert little effort.

We evaluate the role, which the structure of corporate shareholdings plays in the occurrence, the frequency and the outcome of shareholder proposals. For that purpose we need to find suitable measures of 1) ownership stakes held by corporate insiders, 2) the number of institutional investors that hold stock in the company, and 3 ) the number of common shareholders in total. The problem with these variables is that they are strongly endogenous to firm- and stock characteristics. For the last two variables, we therefore follow the methodology by Grullon, Kanatas, and Weston (2004) and Bodnaruk and Östberg (2009) and extract the residuals from the following regression. We regress the skewness-adjusted number of common shareholders (COMPUSTAT item \#100, measured in millions) on firm age, market capitalization, return on assets, market-to-book ratio, the inverse of share price, the stock's liquidity (monthly average trading volume), past year return and past year volatility. These variables are chosen because firm- and stock characteristics attract different groups of investor clienteles and therefore cause different degrees of ownership concentration. As an example, an established NYSE blue-chip firm with low volatility attracts more (institutional) investors than a young and risky firm with little profitability record. We control for exchange listing and industry grouping according to Fama-French 12-classification. The same regression is run for the number of institutional investors with the same control variables. Results of the regression are below.

Consistent with the literature on ownership structure we note that larger and more liquid firms are more likely to have a broader base of common shareholders. Surprisingly, we find that price matters for the base of common shareholders but turns out insignificant for the institutional shareholder base. Transaction costs seem to matter more for the common shareholder base than for institutional investors which is in line with economic intuition. We find that glamour stocks are more likely to have a large investor base and have more institutional investors. Being very liquid in terms of trading volume plays a significant role both for the common as 
well as for the institutional shareholder base. From this regression we extract the residual values and use them for ongoing analysis in later stage regressions of shareholder proposal occurrence, frequency and outcome.

\section{Table 5.5: Determinants of Shareholder Base}

We regress the logarithm of the number of common shareholders (in millions) on the following variables: logarithm of market capitalization (number of shares outstanding times share price), logarithm of firm age, return on assets (operating income before depreciation divided by total assets), logarithm of market to book ratio, the inverse of the share price, the firm's liquidity of the stock (monthly trading volume), its past year return and volatility (standard deviation of monthly returns). We control for exchange trading status and have NYSE as the base variable. We incorporate industry dummies according to the Fama French 12 industry classification. Our estimation technique is OLS and we adjust standard errors for heteroskedasticity. Significance at 10,5 and $1 \%$ level are denoted with *,**, and ***, respectively.

\begin{tabular}{|c|c|c|c|c|}
\hline \multirow[t]{2}{*}{ Variables } & \multicolumn{2}{|c|}{$\begin{array}{c}\log (1+\text { Number of } \\
\text { Common Shareholders })\end{array}$} & \multicolumn{2}{|c|}{$\begin{array}{c}\log (1+N u m b e r \text { of } \\
\text { Institutional Investors })\end{array}$} \\
\hline & Coefficient & $t$-Statistic & Coefficient & $t$-Statistic \\
\hline intercept & $-2.603 * * *$ & -20.584 & $0.550 * * *$ & 11.574 \\
\hline Firm Age & $0.148^{* * *}$ & 10.047 & $0.137 * * *$ & 27.415 \\
\hline Market Capitalization & $0.314 * * *$ & 21.740 & $0.336 * * *$ & 64.715 \\
\hline $\mathrm{ROA}$ & 0.004 & 0.492 & 0.002 & 1.529 \\
\hline Market to Book & $0.194 * * *$ & 13.154 & $0.054 * * *$ & 10.364 \\
\hline 1/Price & $0.061 * *$ & 2.113 & -0.002 & -0.283 \\
\hline Liquidity & $0.164 *$ & 1.850 & $0.215^{* * *}$ & 5.140 \\
\hline Past year return & 0.000 & 0.184 & $0.000 * * *$ & 6.107 \\
\hline Volatility & $-0.942 * * *$ & -8.197 & $-0.471 * * *$ & -10.625 \\
\hline AMEX traded & -0.061 & -0.965 & $0.071 * *$ & 2.423 \\
\hline NASDAQ traded & $1.568 * * *$ & 4.471 & $-0.749 * * *$ & -2.835 \\
\hline Industry FF 12 controlled & \multicolumn{2}{|c|}{ yes } & \multicolumn{2}{|c|}{ yes } \\
\hline Adjusted $\mathrm{R}^{2}$ & \multicolumn{2}{|c|}{0.420} & \multicolumn{2}{|c|}{0.758} \\
\hline Number of Observations & \multicolumn{2}{|c|}{14537} & \multicolumn{2}{|c|}{15195} \\
\hline
\end{tabular}




\section{Table 5.6: CEO and Director and Officer Holdings}

We regress the dollar value of CEO and director and officer holdings on a number of firm-, governance, and ownership variables. All variables are as defined previously. Separate chair equals 1 if the function of CEO and chairman of the board is separated. Board size and percentage of independent directors is obtained from the RiskMetrics "board and directors" tape. Our estimation technique is OLS and we adjust standard errors for heteroskedasticity. Significance at 10, 5 and $1 \%$ level are denoted with *,**, and ***, respectively.

\begin{tabular}{|c|c|c|c|c|}
\hline & \multicolumn{2}{|c|}{$\begin{array}{c}\text { Log(1+CEO dollar } \\
\text { Holdings })\end{array}$} & \multicolumn{2}{|c|}{$\begin{array}{c}\text { Log(1+Director and Officer } \\
\text { Dollar Holdings) }\end{array}$} \\
\hline & coefficient & $t$-stat & coefficient & $t$-stat \\
\hline intercept & $7.585 * * *$ & 22.415 & $9.736 * * *$ & 28.772 \\
\hline \multicolumn{5}{|c|}{ Firm Variables } \\
\hline Firm Age & $-0.148 * * *$ & -3.853 & $-0.262 * * *$ & -6.630 \\
\hline Market Capitalization & $0.204 * * *$ & 4.884 & $0.420 * * *$ & 9.220 \\
\hline ROA & $-0.018 * * *$ & -3.114 & $-0.010 *$ & -1.644 \\
\hline Market to Book & $-0.224 * * *$ & -6.426 & $-0.276^{* * *}$ & -7.288 \\
\hline 1/Price & $-0.854 * *$ & -2.356 & $-0.986^{* *}$ & -2.200 \\
\hline Liquidity & $-0.658 * * *$ & -8.118 & $-0.545^{* * *}$ & -6.774 \\
\hline past year return & $0.002 * * *$ & 4.468 & $0.002 * * *$ & 3.823 \\
\hline Volatility & $0.318 * * *$ & 3.648 & $0.424 * * *$ & 4.578 \\
\hline Debt-Equity Ratio & 0.000 & 1.238 & 0.000 & -0.348 \\
\hline \multicolumn{5}{|c|}{ Governance Variables } \\
\hline Dual Class & $1.025 * * *$ & 10.600 & $1.270 * * *$ & 14.125 \\
\hline Separate Chair & $-1.055^{* * *}$ & -23.102 & $0.153 * * *$ & 3.050 \\
\hline G-Index & $-0.041 * * *$ & -4.556 & $-0.049 * * *$ & -4.965 \\
\hline Board Size & $-0.142 * * *$ & -12.880 & $-0.053 * * *$ & -4.569 \\
\hline$\%$ Independent Directors & $-0.021 * * *$ & -14.904 & $-0.037 * * *$ & -24.183 \\
\hline \multicolumn{5}{|c|}{ Ownership Variables } \\
\hline Institutional Ownership & $-0.556 * * *$ & -4.709 & $-1.592 * * *$ & -12.313 \\
\hline Shareholder Base & $-0.317 * * *$ & -13.548 & $-0.452 * * *$ & -18.346 \\
\hline \multicolumn{5}{|l|}{ Exchange control } \\
\hline NYSE dummy & 0.123 & 0.539 & $-0.338 *$ & -1.646 \\
\hline Industry FF 12 controls & \multicolumn{2}{|c|}{ yes } & \multicolumn{2}{|c|}{ yes } \\
\hline Adjusted $\mathrm{R}^{2}$ & \multicolumn{2}{|c|}{0.251} & \multicolumn{2}{|c|}{0.284} \\
\hline Number of Observations & \multicolumn{2}{|c|}{9052} & \multicolumn{2}{|c|}{9690} \\
\hline
\end{tabular}

As a third group of potential holders of voting rights we turn to the role of corporate insiders. In order to correct for biases in firm sizes, we multiply each director's share of ownership with the year end stock price in order to arrive at share ownership corrected for dollar values. By construction, it is more difficult for CEOs 
of large blue chip stocks to accumulate significant holdings at high share prices, which is why we account for market capitalization. There is a rich body of literature pointing towards the endogeneity of insider holdings and executive compensation (see for example Demsetz and Lehn, 1985 and Demsetz and Villalonga, 2001). For that reason we decide to run the same regression as before for share holdings of 1) the CEO of the firms and 2) holdings of all directors and officers of the firm. We complement the set of stock- and firm characteristic by a list of governance variables, which were shown to have explanatory power on insider holdings (Core, Holthausen, and Larcker, 1999).

We find that for insider holdings many of the previously observed coefficients of the shareholding structure are different. Insiders are more likely to hold larger fractions in value stocks and hold a larger fraction if the stock trades at low levels. Insiders also hold volatile stocks, which have performed well over the past year. With respect to governance variables we observe that a dual CEO holds more shares and thus controls more of the voting rights. A very strong variable is whether the firm has dual class status: in this case both the CEO and directors and officers hold a significantly larger fraction of the voting rights. Managers in firms with weak shareholder rights hold fewer shares. This is not necessarily in contrast to our empirical predictions where we expected poorly-governed firms to have steeper incentives as other corporate governance tools are absent. Our analysis is concerned with the degree to which managers use the voting rights they are bestowed with, not the absolute value of holdings. Moreover, we find that more independent directors on the board result in a lower degree of equity participation. This finding is indicative of the claim that independent directors are more likely to act in the interest of corporate shareholders and thus restrict the use of excessive equity incentive practices.

From this section we conclude that there are significant stock and company characteristics affecting the internal and external shareholder base of a company. In the following we will evaluate the effects of this shareholder base on the occurrence, frequency and outcome of shareholder activism in the form of proxy voting.

\subsubsection{Empirical Results: Determinants of Being Targeted}

To shed light on the probability and the magnitude of being confronted with shareholder proposals of any kind, we adopt a pooled cross sectional specification of the following kind:

$$
\text { \# of proposals } \text { prt }_{i}=\alpha_{i}+\beta_{i} \text { Firm }_{i t}+\gamma_{i} \text { Owner }_{i t}+\delta_{i} \text { Governance }_{i t}+\text { Control }
$$

In this specification, the dependent variable is the number of proposals a company $i$ receives in year $t$. It is important to note that the number of proposals of firm $i$ in 
year $t$ refers to the total number of proposals received by the firm, including the withdrawn and omitted proposals. Firm represents a vector of several firm characteristics. We include the firm's cash position, age, total assets, market-to-book ratio, the dividend yield, past performance, leverage and the shareholder base as firm characteristics. Owner represents a vector of ownership variables. Here, we control for the institutional shareholder base and the disaggregate holdings of certain institutional investor types. Governance is a vector which comprises several different governance variables. This vector includes the variables of main interest: the governance index, managerial incentives and our industry concentration measure, the HHI based on the 3-digit SIC code. Furthermore, we control for industry (Fama-French's 12 industries classification), stock exchange and year effects. In the following, we present the results of our Tobit specifications of equation 2 .

Table 5.7 presents the results of four different censored Tobit specifications. We examine subsets of proposals in order to distinguish the informational content of those proposals. We expect that different proposal topics cause different results regarding our variables of major interest. Model 1 uses all shareholder proposals in our sample (that is, corporate governance and CSR proposals); Model 2 includes corporate governance proposals only, while Models 3 and 4 use external and internal control proposals, respectively. Recall, that we conjecture that the shareholder base and the governance quality are of particular importance for the filing decision of proposals on any topic. Hence, the variables of major interests are those on the shareholder base and the governance quality of firms. More specifically, Residual Shareholder Base and HHI (institutional) represent our proxies for the size of the shareholder base and the level of concentration of institutional holdings while the interaction term G-index*Industry $H H I$ represents the most relevant variable concerning the governance quality of firms.

The results in Table 5.7 support hypothesis H1: Weakly-governed firms are more likely to receive a shareholder proposal. In all four models, the effect of the interaction term G-index*Industry HHI on the mere number of filed proposals is positive. This indicates that companies which are not exposed to fierce competition and the takeover market are more likely to be targeted by shareholder proposals. The effect is significant in three out of four models. Only for external corporate control proposals, the effect is insignificant. This alludes to the fact that shareholders most likely recognize that the exposure towards the takeover market is hardly changeable for weakly-governed firms and hence, shareholders do not put forward proposals of this category. 


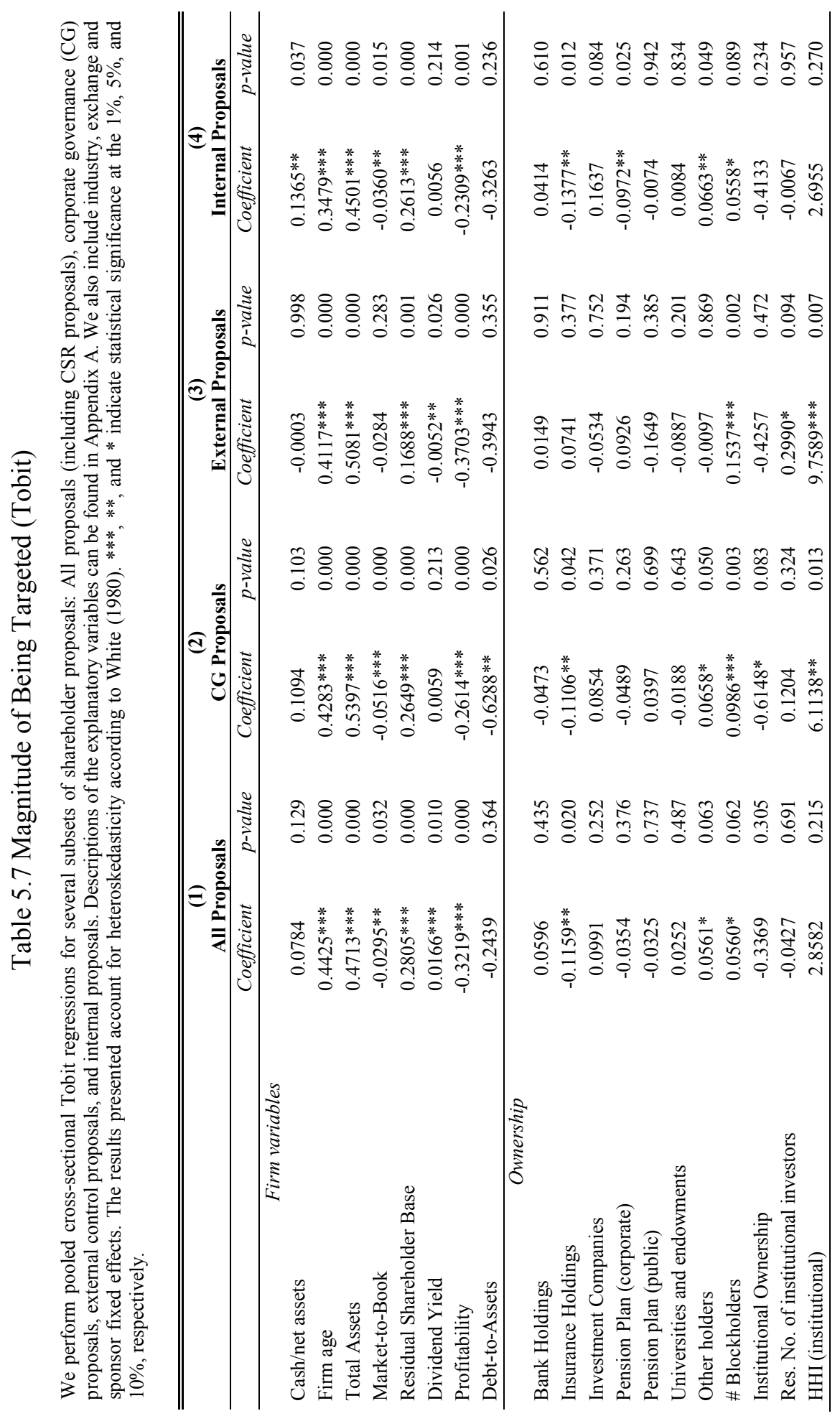




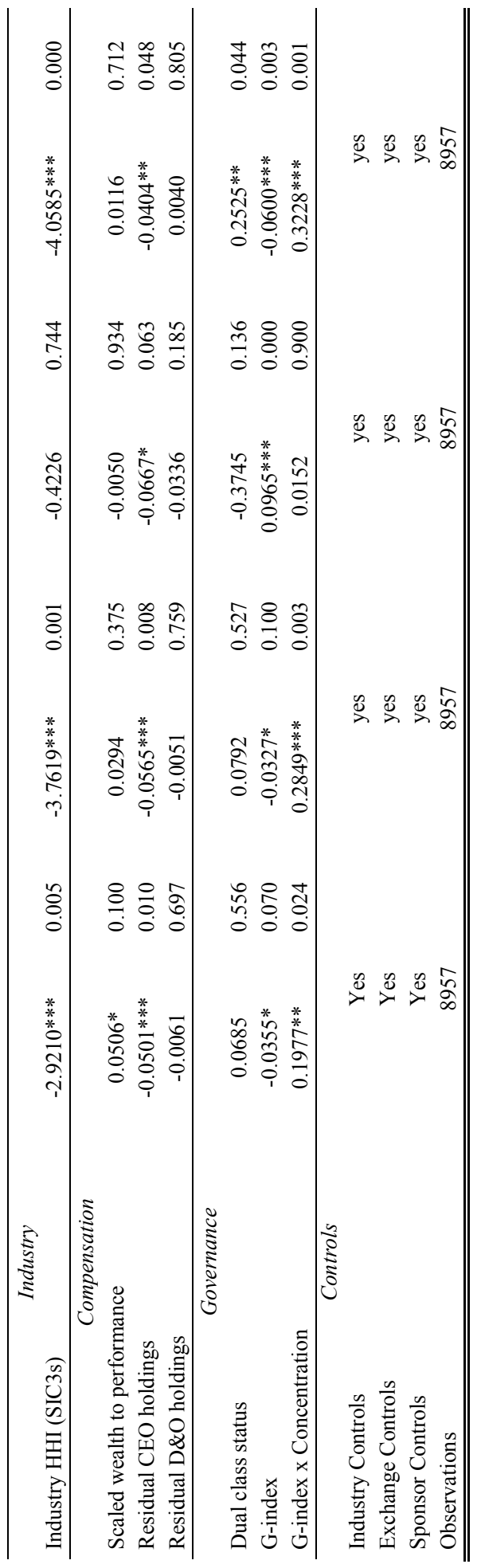


Concerning the ownership structure of firms, we find a positive and a highly significant coefficient on Residual Shareholder Base indicating that a larger shareholder base increases the probability that a shareholder files a proposal. This result holds for all four models. Furthermore, we find that the concentration of institutional shareholdings is always positively related to the number of shareholder proposals a company receives in a particular year. Though the effect is insignificant in models 1 and 4, this result is suggestive of the fact that a higher concentration of shareholdings among institutions increases the likelihood that collusion on corporate issues between them occurs. This in turn, increases the probability that one institution submits a proposal. Overall, these results support hypothesis $H 1 b$ which states that the structure of the shareholder base influences the occurrence of shareholder proposals.

The coefficients on the remaining control variables are generally consistent with the extant literature on shareholder activism. We find that the likelihood of receiving shareholder proposals increases with poor past performance and firm size. Moreover, our results indicate that mature companies are more likely to be targets of shareholder initiatives. The effects of our disaggregate dollar holdings of institutions remain inconclusive. Except for the negative effect of shareholdings of insurance companies (significant in three models), no pattern in disaggregate institutional holdings is observable.

We conclude from this section that the presence of shareholder activism crucially depends on the governance environment of corporations. More specifically, if the disciplining forces from the takeover market and industry competition are absent, the magnitude of shareholder activism increases. That is, shareholder activism can be seen as a substitute for other governance mechanisms that are entirely absent or have failed. However, the analyses so far only give an indication about the presence of shareholder activism; that is in how far shareholders become active at annual general meetings. The results do not show if other shareholders vote with "activist" shareholders or not. In other words, the results do not show how successful and efficient shareholder activism is or which factors influence the efficiency of shareholder proposals. We investigate this issue in the following section.

\subsubsection{Voting outcomes of shareholder proposals}

Having identified the determinants of being targeted by shareholder proposals we continue with the examination of proposals' voting outcomes. Voting outcomes are of particular interest as they amplify managers' abilities to "enjoy a quiet life" when fierce industry competition and the exposure towards the takeover market are absent. Table 5.8 presents the results of our analysis of the voting 
outcomes. As before, we adopt a pooled-cross sectional approach. The models are estimated using ordinary least squares with heteroskedasticity-consistent standard errors. We adopt the following specification

$$
\% \text { votes }_{i t}=\alpha_{i}+\beta_{i} \text { Firm }_{i t}+\gamma_{i} \text { Owner }_{i t}+\delta_{i} \text { Governance }_{i t}+\text { Controls }
$$

where the dependent variable is the percentage of votes cast in favor of a particular shareholder proposal. The explanatory variables are defined as before. In this section, we are particularly interested in the effect of insiders' holdings of voting rights on the voting outcomes of shareholder sponsored proposals, especially when other corporate governance tools are absent. Hence, the variables of major interest are: Board HHI, which measures the concentration of holdings among board members; Q1 dummy, which equals unity if the company is part of the upper right quadrant in our economic model; and the interaction term Q1 dummy*Board HHI, which measures the joint effect of poor governance quality in combination with equity holdings of board members.

Overall, the empirical results of Table VII support hypothesis $H 2$ as insiders' equity holdings are negatively related to the voting outcomes of shareholder proposals: The coefficient on Board HHI is negative and significant in all four models. The economic magnitude, however, is largest for internal control proposals. This result implies that as more voting rights are concentrated among board members, the lower the voting outcomes get. In other words, insiders' holdings of voting rights are voted against shareholder proposals of any kind; they significantly suppress the voting outcomes. This effect becomes even stronger when taking the governance quality of firms into account. Proposals submitted to firms that are poorly-governed in terms of their exposure towards the takeover market and industry competition, receive significantly less votes when insider ownership concentration is high. Voting results of external governance proposals, however, are not negatively related to the interaction term $Q 1$ dummy*Board HHI.

Several other variables do influence the voting outcomes of shareholder proposals. In particular, the number of blockholders, \# Blockholders, overall institutional holdings, Institutional ownership, and the ownership concentration among institutions, HHI (institutional), significantly influence the voting outcomes of proposals. These results stand in sharp contrast to Gordon and Pound (1993) who find that institutional shareholdings do not significantly affect voting outcomes of shareholder proposals. We further find a negative relationship between the scaledwealth-to performance measure (as developed by Edmans, Gabaix and Landier, 2009) and the voting outcomes in all four models. As the scaled-to-wealthperformance measure the incentives provided to managers, irrespective of firm size, it measures in our context how managerial incentives affect the voting outcomes. The significant negative relation between incentives and voting results could stem 
from two sources. First, managers of poorly-governed firms are given more pecuniary incentives in the form of stock or stock options which are subsequently used to vote against shareholder proposals. Second, as a result of more incentives, managers' and shareholders' interests are well aligned so that there is no need for shareholders to vote on proposals.

\subsubsection{Robustness checks}

In this section we test if our previous findings are robust to different specifications of the empirical models. The corporate governance literature has pointed out that there are other direct measures for managerial entrenchment (see for example Bebchuk and Cohen, 2005, Bebchuk, Faleye, 2007, Cohen and Ferrell, 2009 and John and Litov, 2009). This stream of literature claims that the so-called entrenchment index (E-index) and the presence of a classified board are also appropriate measures for managerial entrenchment. Hence, we expect to find the same results when it comes to the determinants of being targeted by shareholder proposals. Tables 5.9 and 5.10 present the results for the occurrence of shareholder activism. In Table 5.9 we replace our initial measure for managerial entrenchment, the G-index, with an indicator variable which equals to one if the firm has a classified board and zero otherwise (classified board). As can be seen from the table, our results essentially remain the same. All variables in each specification display the same signs as in the initial analysis. In Table 5.10 we replace the G-index with the E-index. The E-index comprises a subset of "entrenchment" measures only which are also included in the overall G-index (Bebchuk, Cohen and Ferrell, 2009). Again, we find the same results as before indicating that our results indeed show that poorly-governed firms have a higher likelihood of being targeted by shareholder proposals.

Our main result with respect to voting outcomes of shareholder proposals holds even when controlling for different measures of insider holdings of voting rights. In Table 5.11 we replace our measure for ownership concentration within the board with the total percentage of voting rights owned by corporate insiders. The results in Table 5.11 show that our main conclusion remains the same: Insiders' voting rights significantly reduce the number of votes cast in favor of shareholder proposals and is most pronounced for internal governance proposals. The voting outcomes of external governance related shareholder proposals are also negatively related to insider holdings. However, our variable of interest - the interaction term between $Q 1$ and insider holdings is positive but insignificant implying that voting outcomes of external governance proposals at poorly governed firms are not significantly reduced by insider's voting behavior at annual general meetings. 


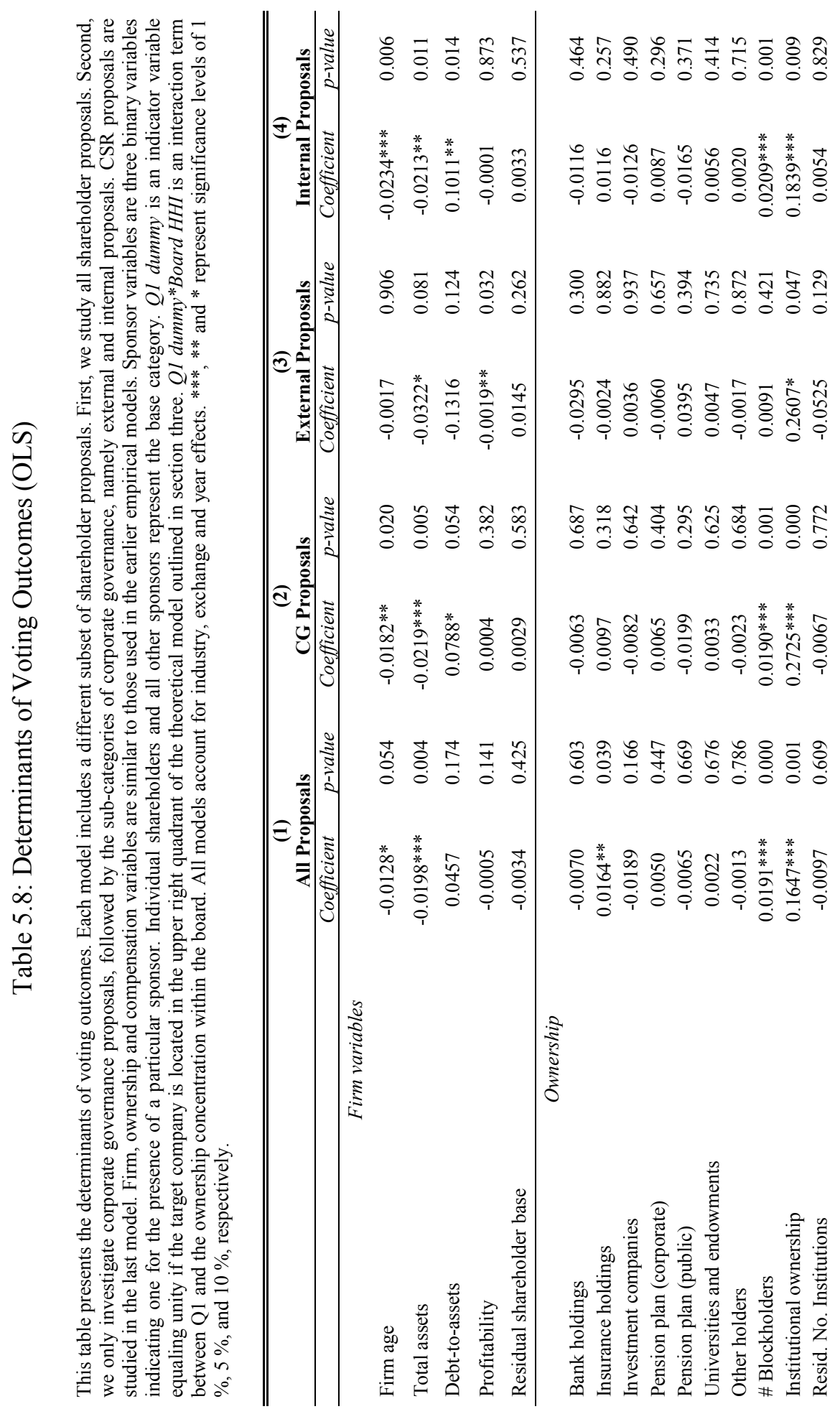




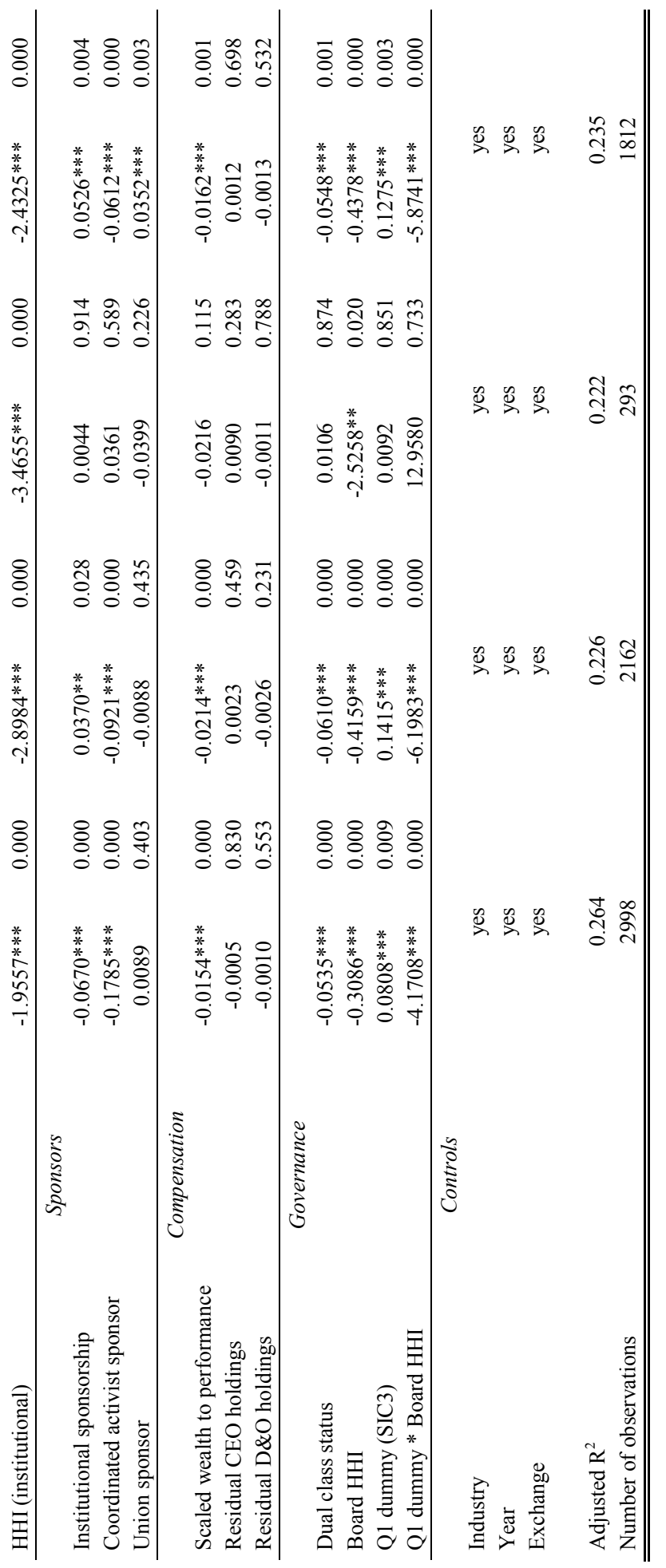




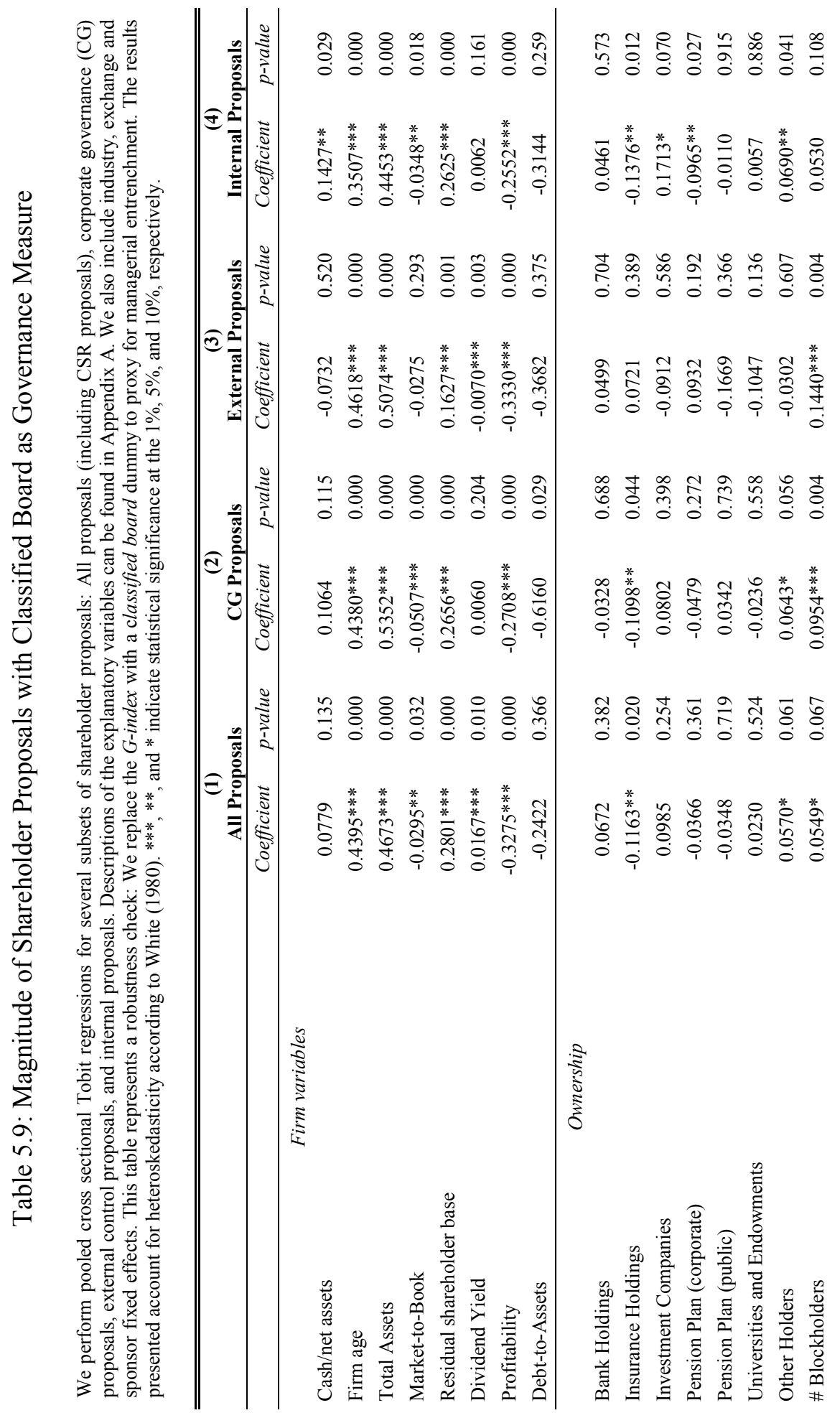




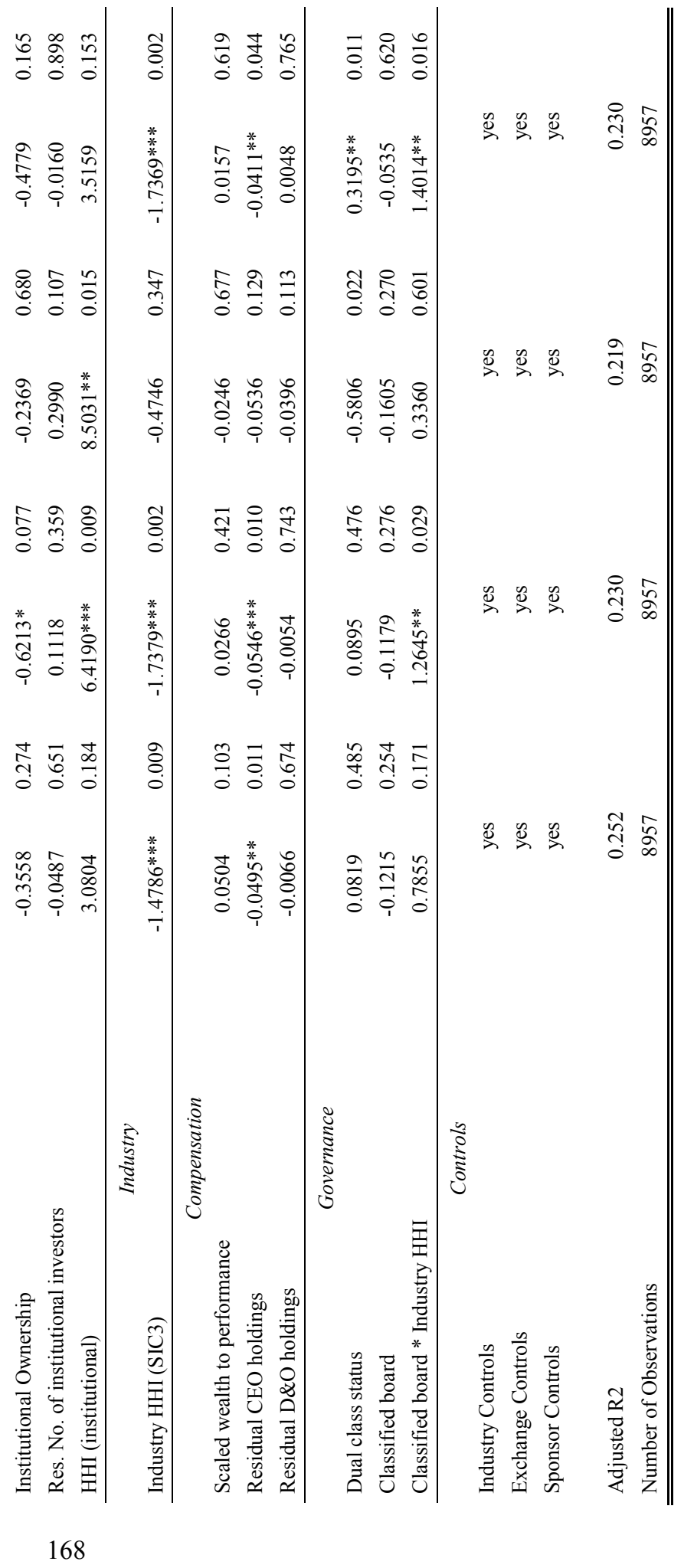




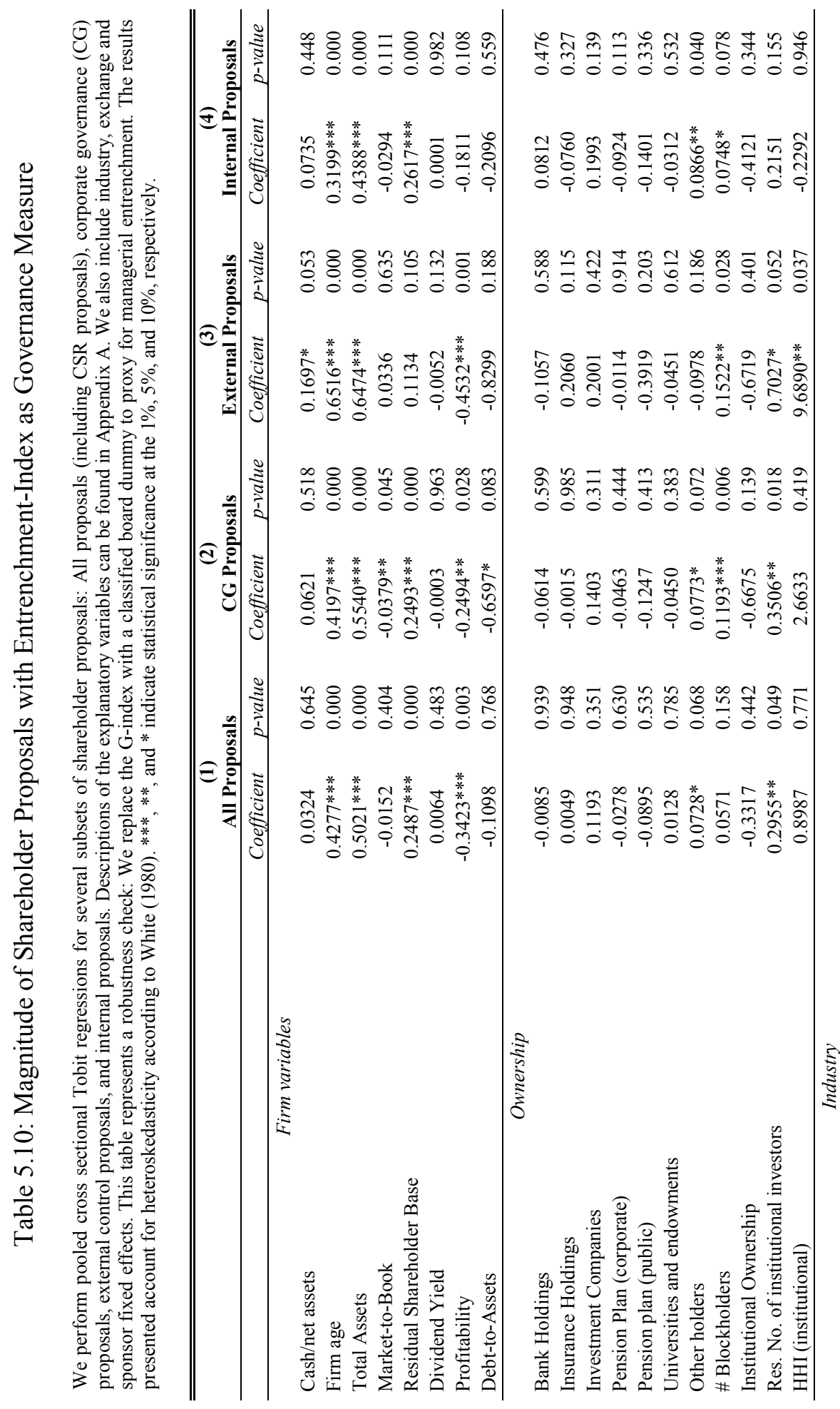




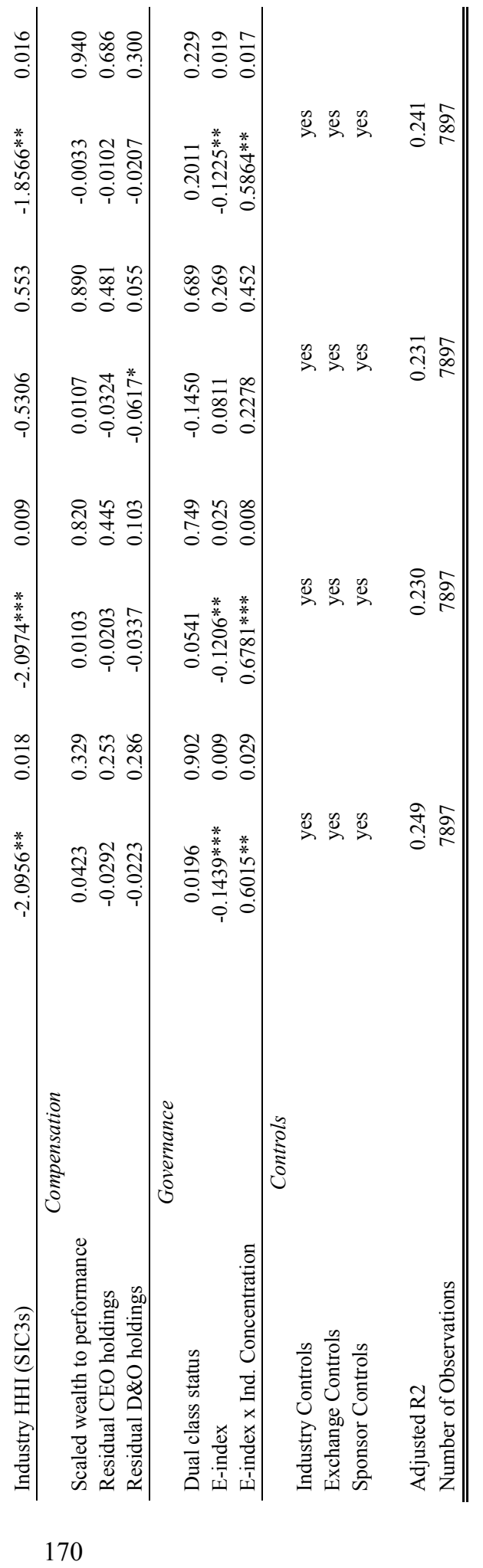




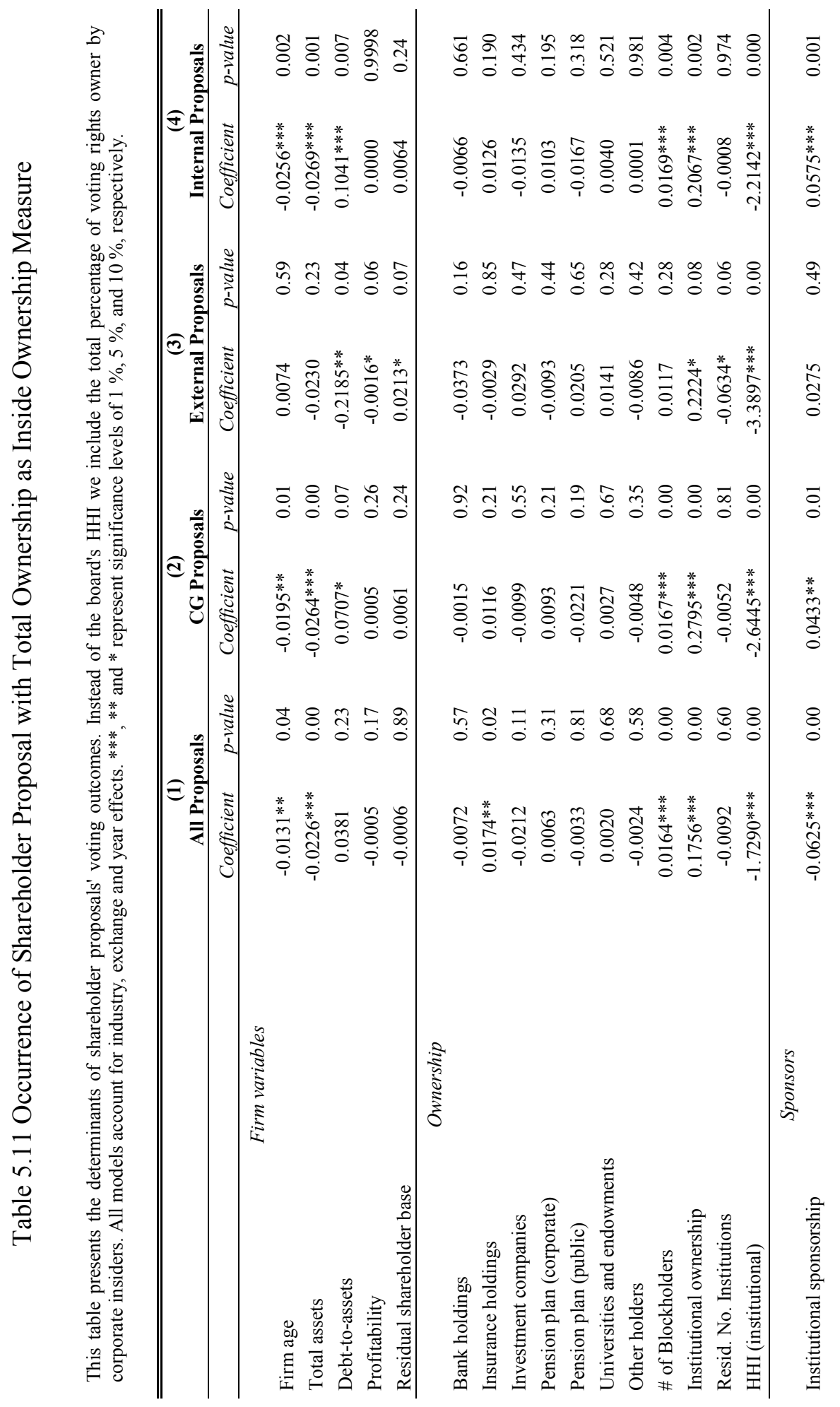




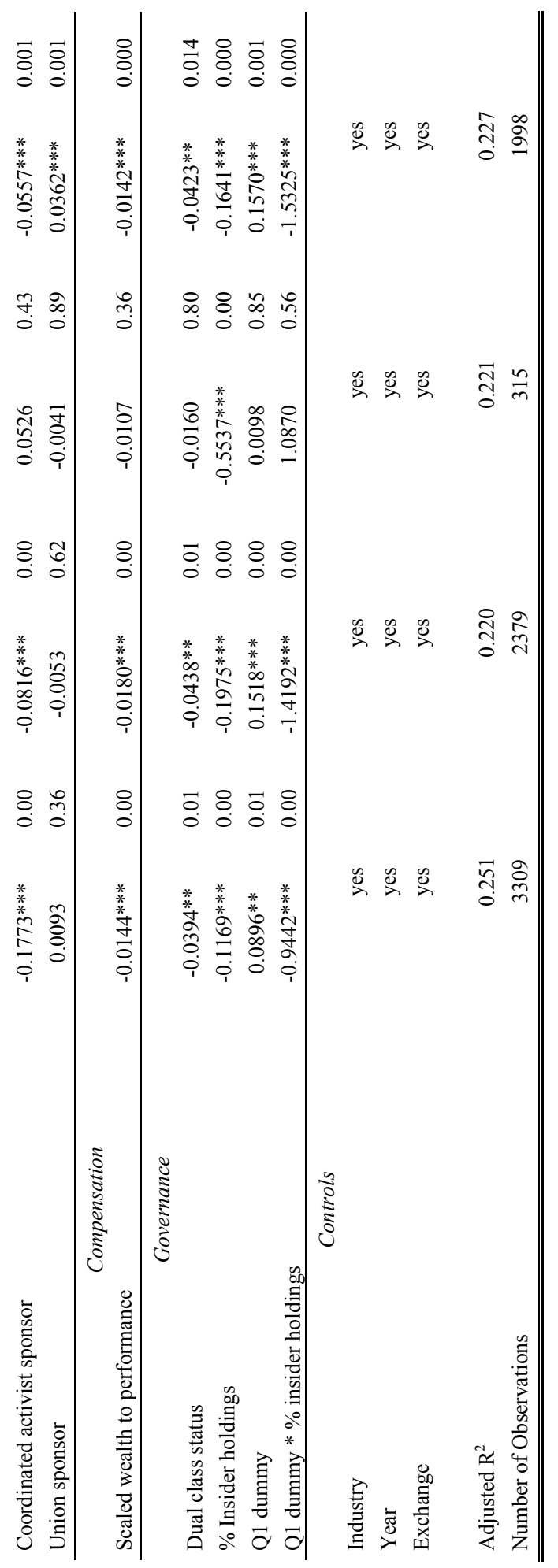


In an unreported further robustness test - inspired by Morck, Shleifer and Vishny (1988) - we also use piecewise linear insider ownership variables. Specifically, following Morck, Shleifer and Vishny, we define three board ownership thresholds: below $5 \%$, from $5 \%$ to $25 \%$ and more than $25 \%$. The results display lower statistical significance but all coefficients confirm a negative relation with voting outcomes of shareholder proposals. We conclude that managers are blocking shareholder proposals.

\subsection{Discussion and Concluding Remarks}

In this paper, we shed light on the determinants of the occurrence and the efficiency of shareholder activism in the form of shareholder proxy proposals in the United States. Specifically, we investigate whether the presence of industry competition and shareholder rights are mitigating factors for the emergence of shareholder activism. Our results indicate that managers have steeper equity incentives as soon as the disciplining forces of the industry competition and takeover market are absent. Most importantly, we find that the odds of receiving a shareholder proposal significantly increase when industry competition and the exposure towards the takeover market are low. Hence, we conclude that poorly governed firms, in terms of the competitive environment and the vulnerability towards takeovers, are exposed towards shareholder proposals which strive for changes in governance structures. Lastly, managers in firms, which lack pressure from the takeover market and competition at the same time, are not able to shirk. These managers are frequently exposed to shareholder activism, which is costly to deal with. The voting outcomes of shareholder proposals at poorly governed firms are significantly suppressed by corporate insiders. As they have to vote actively against such proposals during annual meeting, we conclude that corporate insiders are not able to shirk. Concerning the number of withdrawn proposals, we do not find evidence that the number of withdrawn proposals is significantly higher for poorlygoverned firms. Our results are robust to other measures of shareholder rights or industry competition.

Our results show that there is a positive relation between the firm's governance quality and the likelihood of being targeted by shareholders. Furthermore, we find that insider holdings of voting rights are used to vote against certain shareholder proposal types. Essentially, our results support the view that shareholder proposals can be the last resort of monitoring and influencing managerial behavior or corporate governance structures. Which implications can be inferred from those results and how can we reconcile our results with the existing literature on corporate governance and shareholder activism? 
Neither the probability of being targeted nor the voting outcome itself is consistently and significantly influenced by the institutional shareholder structure. Our results contribute to the existing literature on the efficiency of institutional shareholder oversight. Cornett, Marcus, Saunders and Tehranian (2007) show that only institutions without a business relationship with the target firm are efficient monitors of managers. Likewise, Chen, Harford and Li (2007) provide evidence that only independent institutional shareholders with a clear long-term focus can efficiently monitor management. Our results are different. In particular, we show that the heterogeneity of institutional shareholders causes neither a change in the probability of being targeted nor in the voting outcomes of the proposals brought forward at annual meetings. Overall, the findings regarding institutional shareholdings show that institutional investors are pursuing different interests when it comes to monitoring. Furthermore, as the relationship between institutional holdings and the likelihood of being targeted as well as the voting outcomes is very weak, we argue that institutional investors might rather pursue the Wall-Street Walk and vote with their feet to express their dissatisfaction with corporate managers instead of actively engaging at annual meetings (in the jargon of Parrino, Sias and Starks, 2003). Unfortunately, the "exit" option is outside of our framework.

Our results are important for several parties. First of all, proxy advisory firms which advise shareholders on how to vote at annual meetings can make use of our results and shape their advices in such a way that even poorly governed firms are exposed to potentially successful shareholder activism in the form of proxy proposals. Second, boards of directors that are in charge of designing executive compensation contracts can use our results as a foundation for designing "optimal" contracts. In this respect, an optimal compensation structure would imply that managers are awarded with less stock option packages or other equity-based compensation. To prevent suppressed voting outcomes for shareholder proposals due to a substantial equity ownership by corporate insiders, it is necessary to reduce the share of equity based compensation and raise fixed salaries accordingly. Third, the importance of our paper for regulators offers promising further research avenues in this field. More specifically, our results do have implications for the SEC's design of the proxy proposal process. In particular, as most of the shareholder proposals do not win a majority of votes, it is questionable in how far the proxy proposal process is an efficient monitoring mechanism in the first place. In combination with the fact the shareholder proposals are not binding for companies even if they receive a majority of votes, the economic rationale of this "monitoring" device is debatable. The SEC might consider a change in the voting rules for shareholder proposals, i.e. making shareholder proposals which reach a certain voting threshold binding for U.S. corporations. The enforcement of such a change will definitely change the role of proxy proposals as a corporate governance device. 


\section{Appendix A: Proposal Topics and Sponsor Categories}

\begin{tabular}{ll}
\hline \hline Proposal topics (content) & Topic examples \\
\hline Corporate governance & $\begin{array}{l}\text { Separate chairman/CEO, introduce confidential voting, } \\
\text { repeal classified board, limit director tenure, introduce } \\
\text { confidential voting. } \\
\text { Redeem or vote on poison pill, eliminate supermajority } \\
\text { provision, vote on takeover provisions, restore right to call a } \\
\text { special meeting. }\end{array}$ \\
External governance proposals & $\begin{array}{l}\text { Sell the company, reject merger, spin off division, spin off } \\
\text { tobacco business. }\end{array}$ \\
Takeover & $\begin{array}{l}\text { Label gene-engineered food, adopt sexual orientation anti- } \\
\text { bias policy, implement ILO standards and third-party } \\
\text { monitoring, issue sustainability report, adopt code of conduct } \\
\text { for China operations. }\end{array}$ \\
Social proposals & $\begin{array}{l}\text { Endorse Ceres principles, report on global climate change, } \\
\text { report on supplier environmental standards, reduce } \\
\text { radioactive emissions, develop renewable energy } \\
\text { alternatives. }\end{array}$ \\
\hline \hline Environmental proposals & $\begin{array}{l}\text { Sponsor examples } \\
\text { Proposal sponsors (identities) }\end{array}$ \\
\hline
\end{tabular}

Prop sal sponsors (identities)

Institutional investors

Individual investors

Coordinated activists
California Public Employees' Retirement System, New York City Pension Funds, Calvert Asset Management Co., Domini Social Investments, LongView Funds, Connecticut Retirement Plans \& Trust Funds, Northstar Asset Management, Trillium Asset Management.

Evelyn Davis, Davis family, Gilbert brothers, Rossi family, Lucian Bebchuk.

Interfaith Center on Corporate Responsibility, Medical Mission Sisters, Human Life International, Episcopal Church, Rainforest Action Network, People for the Ethical Treatment of Animals, Pro Vita Advisors.

United Brotherhood of Carpenters and Joiners of America, Service Employees International Union, Plumbers \& Unions
Pipefitters National Pension Fund, Utility Workers Union of America, AFL-CIO, International Brotherhood of Electrical Workers, International Brotherhood of Teamsters. 


\section{Appendix B: Central Variables Used in the Analysis}

\begin{tabular}{|c|c|}
\hline Variable Name & Definition and Source \\
\hline \# Common Shareholders & $\begin{array}{l}\text { Common shareholder base: defined as the number of common shareholders } \\
\text { listed in COMPUSTAT in millions (item \# 100) }\end{array}$ \\
\hline \# Employees & $\begin{array}{l}\text { Number of employees employed by the firm as listed on COMPUSTAT } \\
(\# 29)\end{array}$ \\
\hline Institutional HHI & $\begin{array}{l}\text { Institutional ownership concentration: sum of squared percentages held by } \\
\text { institutional investors. (source: Thomson Reuters } 13 \mathrm{~F} \text { ) }\end{array}$ \\
\hline Board HHI & $\begin{array}{l}\text { Insider ownership concentration: sum of squared percentages of ownership of } \\
\text { corporate insiders (source: RiskMetrics and 10K filings on SEC Edgar) }\end{array}$ \\
\hline Total Assets & Balance sheet total assets from COMPUSTAT (item \# 6) \\
\hline D\&O Holdings (\$) & $\begin{array}{l}\text { Dollar value of director and officer holdings at year end (percentage holdings } \\
\text { times year end stock price) }\end{array}$ \\
\hline D\&O Holdings $(\%)$ & $\begin{array}{l}\% \text { of voting rights held by directors and officers (source: RiskMetrics and } \\
10 \mathrm{~K} \text { filings from SEC Edgar) }\end{array}$ \\
\hline CEO Holdings (\$) & $\begin{array}{l}\text { Dollar value of chief executive officer holdings at year end (percentage } \\
\text { holdings times year end stock price) }\end{array}$ \\
\hline CEO Holdings $(\%)$ & $\begin{array}{l}\% \text { of voting rights held by CEO (source: RiskMetrics and } 10 \mathrm{~K} \text { filings from } \\
\text { SEC Edgar) }\end{array}$ \\
\hline Debt-to-Asset ratio & $\begin{array}{l}\text { Long-term debt plus debt in current assets to total assets (COMPUSTAT item } \\
\# 9 \text { plus \# } 34 \text { over \# 6) }\end{array}$ \\
\hline Dual class status & $\begin{array}{l}\text { Equals unity if the firm has been incorporated with at least a dual class share } \\
\text { (source: RiskMetrics) }\end{array}$ \\
\hline Market Capitalization & $\begin{array}{l}\text { Year end market capitalization: number of shares outstanding times stock } \\
\text { price (COMPUSTAT item \# } 25 \text { times \# 199) }\end{array}$ \\
\hline Market-to-Book & Market Capitalization over book value of equity (COMPUSTAT item \# 60) \\
\hline S\&P500 Listing & Equals unity if the firm belongs to the S\&P500 index \\
\hline \multicolumn{2}{|l|}{ CEO Equity Incentives } \\
\hline CEO Option Incentives & $\begin{array}{l}\text { increases with a } 1 \% \text { change in stock price. Constructed for his entire equity } \\
\text { portfolio ("total"), his "option" portfolio, and his "stock" portfolio. Please } \\
\text { refer to Core and Guay }(1999,2002)\end{array}$ \\
\hline \multicolumn{2}{|l|}{ CEO Stock incentives } \\
\hline Scaled WPS & $\begin{array}{l}\text { Scaled wealth to performance measure from Edmans, Gabaix, and Landier } \\
(2009) \text {. }\end{array}$ \\
\hline Institutional Ownership & $\begin{array}{l}\text { Percentage of outstanding common stock held by institutional investors. } \\
\text { (source: Thomson Reuters } 13 \mathrm{~F} \text { ) }\end{array}$ \\
\hline Res. Shareholder Base & $\begin{array}{l}\text { Residual of a regression of \# Common Shareholders on financial and firm } \\
\text { variables (see Table 5.6) }\end{array}$ \\
\hline \# 5\% inst. Investors & $\begin{array}{l}\text { Number of institutional investors that hold at least } 5 \% \text { of outstanding } \\
\text { common stock }\end{array}$ \\
\hline Residual Inst. Inv base & $\begin{array}{l}\text { Residual of a regression of \# Common Shareholders on financial and firm } \\
\text { variables (see Table 5.6) }\end{array}$ \\
\hline
\end{tabular}




\section{Chapter 6}

\section{The Emerging Market for European Corporate Governance: The Relationship between Governance and Capital Expenditures, 1997-2005}

We examine European corporate governance with respect to the relationship between shareholder value and capital investment. Based upon Europe's largest listed companies, it is shown that Anglo-American conceptions of shareholder value are increasingly important for European firms whatever their home jurisdictions and inherited traditions. Using annual capital expenditures as a proxy for corporate managers' commitment to shareholder value it is shown contra arguments to the effect that the map of European corporate governance regimes is fixed and virtually immutable, even large firms from paradigmatic stakeholder regimes believed focused upon long-term value increasingly act to maximize short-term shareholder value. We divide Europe into three regions based on ownership concentration, legal systems, board structures, and the presence of corporate governance codes. In this multi-jurisdictional setting, we compare the effects of different elements of corporate governance on capital expenditures in each region. Our analysis shows that the overall effect of investor-sensitive corporate governance on capital expenditures is consistently negative notwithstanding differences in the formal nature and quality of governance standards between regions. We explain this finding by reference to the governance standards of United Kingdom: a market for corporate governance that has come to dominate its continental European neighbors.

\subsection{Introduction}

There is a growing European market for corporate governance. Large continental companies appear to be adopting shareholder-friendly practices more

\footnotetext{
${ }^{1}$ This chapter is based on Bauer, Braun, and Clark (2008), published in the Journal of Economic Geography.
} 
consistent with global financial market imperatives than their national traditions. In particular, we argue in this paper that the market for corporate control is increasingly important in promoting short- and medium-term shareholder value. Whatever the formal significance of concentrated ownership regimes in continental European countries, managers appear to be discounting long-term stakeholder value. Whereas Dore (2000) contrasts the Anglo-American approach of revenue and cash distribution to shareholders with the continental European (especially German) approach of retained earnings and investment, we seek to show that large European firms are more short-term oriented than hitherto acknowledged.

By convention, there are two approaches to the study of corporate governance and shareholder value. The first, believed practiced by continental European and Japanese firms, assumes concentrated ownership and capital intensity with investment focused on the generation of long-term value. According to Dore (2000, p. 187), in this type of regime "profits represent the cash available for investments or wage increases rather than the size of the capitalists 'take'." This model of governance seeks to satisfy multiple 'insider' stakeholders assuming that short-termism would otherwise undermine long-term competitiveness. By contrast, in Anglo-American governance systems investors and portfolio managers favor the short-term distribution of excess cash over retained earnings (Aguilera, Rupp et al., 2007). In part, this is due to a distrust of managers who are suspected of hubris and a propensity for empire-building. Equally, investors might not be able to estimate the economic benefits of medium- and long-term investment. These stylized facts have dominated research on comparative corporate governance over past few decades (see Gordon and Roe, 2004, Hopt et al. 1998, and McCahery et al., 2002).

Case studies have challenged the robustness of these 'facts'. For example, it has been shown that when global investors demanded greater transparency and board independence at Royal Ahold, management responded with board reform (Clark, Wójcik and Bauer, 2006). Likewise, it is apparent that shareholder pressure led to Jürgen Schrempp's resignation at Daimler Chrysler AG; his vision of a 'world corporation' was not realized with consequent poor rates of return for global investors. As a result, the Chrysler unit was sold-off to the U.S. private equity firm Cerberus in May 2007. Global institutional investors including hedge-funds have routinely targeted large European blue-chip companies cross-listed at international exchanges. In play are both the short-term trajectory of company stock market prices and the governance of those companies recognizing that board structure and performance are intimately related to the sensitivity of external constituents to targeted firms (Becht et al., 2003).

In this paper, we argue that it is not plausible to assume an immutable European map of corporate governance regimes; in fact, there is evidence that the 
management behavior of Europe's largest firms is increasingly consistent with the market for corporate control (Clark and Wójcik, 2007). In doing so, we go beyond case studies to a systematic analysis of 395 European firms testing for regimespecific differences in the relationship between corporate governance, management behavior and shareholder value. To do so, we use annual capital expenditures as a proxy for manager behavior. Research in the U.S. using this variable showed that lower capital expenditures lead to higher market valuation and stock market performance (Gompers, Ishii, and Metrick, 2003). In a related paper, Titman, Wei, and Xie (2004) showed that U.S. investors react positively to reductions in capital expenditures because investors infer that lower capital expenditures will produce higher distributed dividends in the future. Basically, institutional investors are suspicious of managers of companies with weak shareholder rights, believing managers invest for their own benefit (see, for example, Bertrand and Mullainathan, 2003 and Yermack, 2006).

Here, we assume that manager commitment to shareholder value is manifested in the pattern of corporate capital expenditures. This relationship is evaluated in relation to investor-sensitive elements of corporate governance while controlling for other factors influencing companies' investment decisions. Disaggregate data is used to measure corporate governance based upon a proprietary database made available from a commercial rating agency. In particular, we test this relationship across European governance regimes using three 'regions' based upon inherited legal traditions, market structure, and the prevalence of formal codes of governance. In the empirical sections of the paper, we test for the existence of a continental European approach to shareholder value and capital expenditures. We hypothesize (1) there is a significant effect of corporate governance on management behavior, and (2) managers have adopted practices consistent with the preferences and actions of global portfolio investors.

Our study contributes to the interdisciplinary literature on corporate governance and economic geography in two ways. First, we provide evidence to the effect that corporate governance has an impact on management behavior and performance. We show that governance, and the range of takeover defenses in particular, can affect managers' capital expenditures. ${ }^{2}$ Companies with a high score on overall investor-sensitive corporate governance and low takeover barriers invest less than their industry peers. Second, we find that these results hold across Europe notwithstanding the historical significance attributed to three different regimes of

\footnotetext{
${ }^{2}$ Throughout, we refer to the elements of corporate governance relevant to institutional investors and the formal models of governance embedded in nation-state rules and regulations. In effect there is a distinction made between the theory and practice of corporate governance, emphasizing the latter in relation to the former. Hence, our study is relevant to debate in economic geography over the varieties of capitalism and path dependence (Peck and Theodore, 2007), and argument in governance studies over the political structure of national traditions (see Monk, 2008 and Roe, 2006).
} 
corporate governance. As a result, it is contended that managers are adopted practices consistent with the interests of global investors even if convergence between national models of corporate governance is less systematic than hoped for by global portfolio investors. Even managers domiciled in countries with less well established governance codes and limited takeover markets appear to be adjusting to Anglo-American expectations regarding shareholder value. In these ways, the United Kingdom is the litmus-test for European corporate governance.

The paper is organized in the following manner. Section two presents theoretical aspects of the debate about corporate governance and convergence, and explains how governance and patterns of corporate capital expenditures may be related. We also summarize what is expected in terms of the empirical results. Thereafter, the data on governance and corporate financial performance are explained as is the methodology used to test the research hypotheses. Section four summarizes the empirical results, which are discussed in more detail in section five both in general and from the perspective of economic geography. Lastly, the conclusion draws implications for future research and notes possible short-comings in the analysis.

\subsection{Theory of European Corporate Governance}

Corporate governance differs across countries in terms of ownership concentration and board structures, legal heritage, and management authority. Nonetheless, Shleifer and Vishny (1997) distinguish between two generic regimes. Dispersed ownership regimes typically have an active market for corporate control, where short-term shareholder value is the company's primary objective. If typical of Anglo-American countries, continental Europe is characterized by concentrated ownership and controlling 'insiders' who directly monitor and discipline management. In theory, companies in this type of regime embrace the concept of medium- and long-term stakeholder value (Burkart and Panunzi, 2008). Unlike continental Europe, public companies in the United Kingdom and Ireland tend to have highly dispersed owners such that almost everyone is an 'outsider' such that the threat of being taken over is, presumably, the disciplining force on management. Continental Europe firms also carry the burden of more detailed and rigid regulations compared to the principles approach that holds sway in the UK.

In response to the governance scandals of the first years of the decade, it appears that many larger European firms have adopted more shareholder-friendly practices. Companies either signal increasing commitment to governance quality by cross-listing on international exchanges or by their voluntary compliance with higher transparency and investor-friendly standards. It is often contended that superior systems of corporate governance are to be found in the United States and in 
the United Kingdom; it is widely believed that as global capital markets become more integrated and more correlated in terms of performance, continental European companies are likely to converge to international best-practice standards of governance. $^{3}$ According to Clark and Wójcik (2007, p. 34), it is also widely believed that best-practice is considered by market agents to be a "perfected version of Anglo-American corporate governance with its primary objective of maximizing shareholder value $[. .$.$] and firms' access to external funds."$

Just as European corporate governance has been changing in response to globalization, institutional investors through their corporate engagement strategies have become important in accelerating change. In a number of cases, institutional investors have sought to influence the corporate governance and transparency of blue chip companies (Hebb, 2006). More generally, investors have become more explicit about their evaluation of corporate governance deliberately referencing international standards in the assessment processes. ${ }^{4}$ On the basis of governance best-practice, they have lobbied management to improve their practices and governments to develop national codes consistent with global standards. Consequently, the shareholder value perspective has become more significant irrespective of the legal environment in which target companies are headquartered. Given that Anglo-American standards of corporate governance are often invoked as representative of "best-practice", we hypothesize that large continental European firms increasingly behave like UK-based companies with regard to capital expenditures and retained earnings.

To illustrate, consider the recent history of Royal Ahold and Daimler Chrysler. Between 1998 and 2001, the Dutch retailer Royal Ahold engaged in worldwide acquisitions totaling 16.4 billion Euros (Wrigley and Currah, 2003). Most acquisitions took place in South America but were rather unsuccessful when judged by the return on capital invested. Deficient corporate governance practices, lax internal controls, and media-hype had ceded the CEO considerable control over investment decisions. A clinical study by de Jong et al. (2008) reveals that the company's shareholders viewed most of these investments as indicative of CEO hubris and his penchant for empire building. Another, more recent, instance is DaimlerChrysler AG. Its former CEO's idea of a 'world corporation' involved global acquisitions and diversification into unrelated fields. Shareholder disapproval of this strategy and perceived excess investing resulted in inferior stock market

\footnotetext{
${ }^{3}$ The idea of global best-practice is contested in economic geography, given the path-dependence of national traditions and institutions (see Gertler, 2001). Here, we refer to a decision-relevant reference point for institutional investors rather than an absolute measure of institutional quality that dominates the design of national governance systems.

${ }^{4}$ We note that institutional investors tend to evaluate "good corporate governance" from the perspective of their equity holdings, thereby neglecting creditors. In this paper, we focus on the former evaluation process (see Cremers et al. 2007 on the relationship between bondholders and corporate governance).
} 
performance in the years subsequent to the acquisitions. Institutional investors became impatient with the strategy of global expansion and diversification; poor operating performance led to the disposal of the Chrysler unit in 2007.

The cases of Royal Ahold and DaimlerChrysler demonstrate institutional investors' skeptical views about corporate investment in fixed assets. Assuming managers invest in order to create shareholder value, capital expenditures (CAPEX) and the value of earnings retained or distributed to shareholders are deemed indicative of incumbent managers' approaches towards value creation. Capital expenditures are, of course, vital for any company-in theory, CAPEX sustain a firm's competitiveness assuming that discounted future cash flows exceeding costs. Here, we demonstrate empirically that there is a systematic link between the measured quality of the elements of investor-sensitive corporate governance and the relative value of CAPEX holding constant capital demand, cash flow, and cash availability. If expectations of best-practice governance exert a disciplining influence on managers' investment decisions and constrains the potential for empirebuilding, by this logic managers should identify only profitable projects against rigorous internal controls.

It is entirely possible, of course, that such discipline or the threat of discipline encourages risk-averse behavior resulting in chronic under-investment. This need not be beneficial over the long-term for investors and other stakeholders including employees (Stein 1988). However, institutional investors typically manage such risks through portfolio diversification so that long-term investor commitment is unusual. As a consequence, local stakeholders may be the losers in these circumstances; managers face a trade-off between serving institutional investors, long-term competitiveness, and playing favorites with local stakeholders. ${ }^{5}$

Our hypothesized relationships are explored with reference to three European governance regions or regimes. We test for the existence of differences in the proposed relationship across regimes, consistent with those that suppose that the differentiated map of corporate governance produces systematic differences is financial structure and performance (see La Porta et al. 2002). We also allow for the possibility that shared financial market imperatives drive manager behavior such that whatever the formal differences between European regimes of corporate governance, managers are increasingly sensitive to the significance of CAPEX for institutional investor expectations (the argument underpinning Clark and Wójcik 2007). If we can show that across European regimes of governance the sign on the relationship between corporate governance and capital expenditures is the same, this

\footnotetext{
${ }^{5}$ Recent papers that have addressed companies' relationship to local stakeholders and employees include Pagano and Volpin (2005) and Cestone and Cespa (2007) who provided evidence of managers exploiting their relationships with stakeholders.
} 
will be used as evidence for convergence in management behavior. Even though there are different types of governance codes across Europe, many of which are not equally legally binding, it could be observed that managers in companies from 'weaker' governance regimes opt for behavior consistent with Anglo-American standards.

Countries like France and The Netherlands have established, long-standing and firm governance codes. Disclosure on whether companies comply (mostly based on the doctrine of "comply or explain") with these codes can be either a function of prevalent local listing requirements or embedded in national law. In other countries like Sweden and Norway, formal codes of governance that match or mirror international standards have only recently been introduced. So as to capture these developments, we use three European regions designed to reflect differences in board structure, governance codes, and legal traditions. This allows us to compare the effect of governance on capital expenditures across European regions before pooling the samples into continental European and pan-European samples. That corporate governance codes may have an effect on firm investment has been readily noted in the literature. Chhaochharia and Grinstein (2007) analyzed the consequences of the Sarbanes-Oxley Act for U.S.-listed companies' share price performance and market valuation. They concluded that the effect is positive for large-cap companies and less positive for small firms. Our analysis focuses on largecap stocks in Europe which are the subjects of governance strategies by investment institutions.

Prior work by Gompers, Ishii, and Metrick (2003) sought to explain the financial outperformance of well-governed U.S. companies over badly governed counterparts. They showed that well-governed companies engage in less capital expenditure and less acquisitions. However, their estimate of governance quality was rather idiosyncratic. Furthermore, it would be difficult to show that their measure is recognized as such in the actions of institutional investors. Titman, Wei, and Xie (2004) also investigated the capital investment and return relationship concluding that shareholders view a reduction in capital expenditures positively. Here, by contrast, we take a direct approach to the issue of governance quality and use data provided by a dedicated governance rating agency. In particular, we investigate four elements of investor-sensitive corporate governance plus an overall governance score: the rights and duties of shareholders, the range of takeover defenses, disclosure on corporate governance, and board structure and functioning. The rating database which we use is based upon the FTSE EuroTop 300 largest European companies. Large institutional investors use this database to inform their investment decisions. Hence, our analysis directly reflects elements that institutional investors believe important when considering investment strategies. 
We motivate our analysis in the following way. Firms with higher overall scores on investor-sensitive corporate governance should be more prudent on CAPEX. The subscores on the range of takeover defenses and board structure and functioning should, in theory, also lead to more prudent capital investment. If managers are entrenched and isolated from the market for corporate control, they will face less pressure to create short-term shareholder value. Expectations about the direction of association on the rights and duties of shareholders and disclosure on corporate governance cannot be made a priori but we expect these variables to affect investment decisions. With more rights, managers may grant (minority) shareholders more power to influence corporate strategy. Since disclosure on corporate governance includes the transparency of remuneration practices, this element helps investors hold managers accountable on investment. Board structure and functioning is the fourth category in the database and refers to the quality and robustness of internal controls. If managers face vigilant supervision and audits, they may invest more efficiently and be less prone to conceal perks.

Most importantly, we expect the effect of investor-sensitive corporate governance variables on capital expenditures to be similar across Europe despite being tested in a multi-jurisdictional setting. In continental Europe, controlling insider shareholders are supposed to be the disciplining force affecting management behavior whereas in the UK this influence is typically located in the market for corporate control. There is ongoing debate as to whether market agents view reductions in CAPEX positively or negatively. Royal Ahold's stock price had shown adverse movements before the actual date of earnings restatement, which indicates that some financial analysts had made negative assessments about the consequences of lavish corporate spending (see generally Yermack, 2006). The problems of the continental European model of corporate governance were widely recognized in the late 1990s, even before they became apparent in Ahold and DaimlerChrysler. Given the leverage of institutional investors, and empirical evidence to the effect that shareholders prefer lower capital expenditures, we expect managers to adopt Anglo-American practices even if nation-specific regimes remain wedded to political interests (compare Roe, 2006). 


\subsection{Study Data and Methodology}

\subsubsection{Data}

Institutional Shareholder Services (ISS) Europe (formerly Deminor Ratings S.A.) provides scores on European corporate governance standards. ${ }^{6}$ The time horizon of the database is unusual in that no other European scoring system focused on investor-sensitive categories of governance covers the same period. Four broad categories sum to a Total governance score. The first category "rights and duties of shareholders" (RDS) can be described as the extent to which (minority) shareholders are able to influence a company's actions. The second category "range of takeover defenses" $(T D)$ charts the potential barriers to hostile takeovers thereby protecting management from the market for corporate control. "Disclosure on corporate governance" (DCG) summarizes the availability and quality of financial and nonfinancial information. Lastly, "Board structure and functioning" $(B S F)$ evaluates board diversity, experience and the independence of board members, as well as the insider/outsider mix and remuneration practices.

Scores range from zero to ten and are updated by Deminor on a yearly basis. The available data used in our paper ranges from 2000-2005. Excluded from the analysis are twenty companies from Austria, Greece, Portugal and Luxemburg since firms from those countries are not continuously rated. In order to increase the time horizon and thereby upgrade the statistical validity of our tests, we extended the ratings backwards by three additional years by holding 2000 scores constant to 1997. Since ratings hardly changed over the period 2000-2002, we believe that this is a reasonable approach. Deminor covered a total 395 companies over the six year period, which gave us a total of 3950 firm-level observations with the backward extension. We are aware that using this database depends upon the skill and expertise of the rating agency. But we contend that Deminor has proven to be an effective analyst both for individual companies and across European regions. In any event, Deminor measures are more systematic and consistent on crucial issues than other similar approaches extant in the literature (compare with Gompers et al., 2003).

The main users of the database are institutional investors, who use the ratings as a baseline for their investment decisions. Information gathered by analysts to produce these ratings is publicly available if sometimes difficult to collate and synthesize so as to reflect market information rather than inside

\footnotetext{
${ }^{6}$ In the following we refer to the governance database as the "Deminor" database. A detailed description of the database and its categories can be found in Appendix A (see also Clark and Wójcik, 2007 and Wójcik 2006).
} 
information (Wilhelm and Downing, 2001). The database is comprehensive and ratings do not place equal weight on the measured provisions as in Gompers et al.'s (2003) synthetic self-constructed G-score. The Deminor rating algorithm takes into account approximately 300 characteristics to arrive at a weighted rating score. Bauer, Otten, and Günster (2004) have used the Deminor database to investigate the possible outperformance of well-governed over badly governed European companies. Renders and Gaeremynck (2006) used the same information to study the link between governance and operating performance from an accounting perspective. Lastly, Wójcik, Clark, and Bauer (2005) used the database to check for differences in governance ratings for cross-listed firms.

The second database comes from Worldscope. Capital expenditures (CAPEX) were derived from firms' cash flow statements and counts as 'additions to fixed assets'. Data was obtained on firm's total assets $(T A)$ and sales revenues $(S R)$ with, as well, data for control variables including trailing three-year-sales-growth $(S G 3 Y)$, the price-to-book ratio $(P B)$, and Tobin's $q$. Additionally, we utilized cash flow to sales ratio $(C F S)$, and firm's cash ratio $(C R)$ which is defined by Dittmar and Smith (2007) as the ratio of cash and cash equivalents over net assets (balance sheet total assets minus cash and cash equivalents). Finally, we included a debt-to-assets ratio $(D A)$ variable to capture capital-structure effects. Tobin's $q$ is the market value of assets divided by the replacement value of assets. Market value is approximated by the sum of the book value of assets and the market value of firm equity. From this, the book value of equity is subtracted. The replacement value of the assets is simply the book value of assets. Although there are more sophisticated measures of capturing Tobin's metric, we assume that this is a reasonable approximation. ${ }^{7}$ Log $P B$ represents the natural logarithm of the ratio of the market value of equity and book value of equity (plus balance sheet deferred taxes). Since the variables are ratios, currency effects are not considered. Even though a sizeable number of companies in the sample went through major restructuring during this period with name changes, merger activities, and bankruptcies our database remains robust over the sample period. Table 6.1 shows how our sample is distributed across western European countries.

\footnotetext{
${ }^{7}$ For a detailed discussion of different measures of Tobin's $q$, we refer to Erickson and Whited (2001) and Perfect and Wiles (1993).
} 


\section{Table 6.1: Overview of countries in the sample and data size}

Note covered countries in the sample, average number of companies per country from 2000-2005 and regional belonging. Criteria of belonging to any of the three regions have been shown in section 3.2. of the text. The last row shows the total average number of companies in the sample and per region. The date of issuance of the prevailing governance codes was according to the index of codes and principles of the European Corporate Governance Institute's website (WWW.ecgi.org). If two dates are stated in column two the most recent date refers to a revision.

\begin{tabular}{|c|c|c|c|c|c|}
\hline (1) & (2) & (3) & (4) & (5) & (6) \\
\hline Country & $\begin{array}{l}\text { date of issuance of first } \\
\text { governance code }\end{array}$ & $\begin{array}{c}\text { average \# of } \\
\text { companies }\end{array}$ & Region 1 & Region 2 & Region 3 \\
\hline Belgium & 1998 & 10 & $X$ & & \\
\hline Denmark & $2000 / 2005$ & 5 & & $\mathrm{X}$ & \\
\hline Finland & 2003 & 5 & & $X$ & \\
\hline France & $1995 / 1998$ & 40 & $\mathrm{X}$ & & \\
\hline Germany & $1998 / 2002$ & 30 & $\mathrm{X}$ & & \\
\hline Ireland & 2000 & 5 & & & $\mathrm{X}$ \\
\hline Italy & $1999 / 2003$ & 23 & & $\mathrm{X}$ & \\
\hline Norway & 2004 & 4 & & X & \\
\hline Spain & $1998 / 2003$ & 12 & & $\mathrm{X}$ & \\
\hline The Netherlands & $1997 / 2003$ & 20 & $X$ & & \\
\hline Sweden & 2005 & 17 & & $X$ & \\
\hline Switzerland & 2003 & 17 & & X & \\
\hline United Kingdom & $1992 / 2000$ & 82 & & & $\mathrm{X}$ \\
\hline TOTAL & & 270 & 100 & 83 & 87 \\
\hline
\end{tabular}

The heterogeneity of nation-wide corporate governance codes and prescriptions in the countries under investigation is illustrated by Column 2. We investigate three distinct European regions in order to test for statistically significant differences in the relationship between corporate governance and investment. The country with the most robust corporate governance code is the United Kingdom. Since the UK stock market is highly liquid and because ownership is dispersed takeover barriers are low, and the market for corporate control is active (Burkart and Panunzi, 2006). Moreover, according to La Porta et al. (2002) the UK's common law heritage plays a significant role in underpinning market liquidity. Therefore, as suggested by Tirole (2001), firms in the UK are more likely to embrace the concept of shareholder value: it is the reference jurisdiction for much of continental Europe.

Most continental European companies are located in civil law systems. Furthermore, continental Europe is often characterized as being bank-driven whereas the UK and Ireland are deemed governed by financial markets. The broad 
concept of stakeholder society, which is prevalent in continental Europe, suggests a more complex objective function than that summarized by the phrase shareholder value (see Jensen, 2000). Germany is often invoked as the best example of this type of governance system, where stakeholders like banks, labor unions, and community representatives sit with executives on companies' supervisory boards (Dore 2000). As such, region one is comprised of two-tier structured systems, whereas both region two and the United Kingdom and Ireland have unitary boards. As shown in column two of Table 6.1, the three regions have different histories of corporate governance codes and thus may function differently. Formal differences in corporate governance are manifested in countries' Deminor ratings as shown in Table 6.2. The lower part also shows descriptive statistics on a regional level.

As expected, the United Kingdom together with Ireland had by far the highest total scores on investor-sensitive corporate governance. As noted above, this is due to the active market for corporate control and the limited significance of takeover defenses. Consequently, scores on the $T D$ category are very high. The particularly low scores on $T D$ in Italy, Spain, and Denmark are probably due to the frequent presence of golden shares and ownership ceilings. ${ }^{8}$ In columns 3 and 4, both UK and Ireland take leading positions. Due to large supervisory boards and limited commitment to independent boards of directors, Germany scores very low on $B S F$. Surprisingly, Germany scores high on $R D S$, which might be partly attributable to employee codetermination laws. If we focus on the time-series behavior of our relevant corporate governance and capital expenditures variables, we can confirm the growing importance of governance in the raw data. Since we assume Deminor scores represent institutional investors' awareness of corporate governance standards, we interpret an increasing score as growing importance. The TOTAL score strictly and monotonously increases in every corporate governance region, whereas the variable of scaled and adjusted capital expenditures does not increase. The industries covered in the sample are listed in Table 6.3. The table reveals differences in corporate governance ratings among European industrial sectors. Both telecoms and utilities score comparatively low on the range of takeover defenses. One explanation is that governments frequently own golden shares in firms in these sectors which renders any takeover attempt as burdensome for the acquirer thereby protecting incumbent management.

\footnotetext{
${ }^{8}$ A "golden share" is defined as the government having the final decision over changes in control (i.e. takeovers) or major financial decisions if it judges to endanger national interests (Damodaran 2002). 


\subsubsection{Methodology}

Capital expenditures are subject to both industry- and country effects and are sensitive to company size. ${ }^{9}$ Consequently, the dependent variable capital expenditures was standardized by sales revenue $(S R)$ so as to account for firm size. This standardized measure of CAPEX is also held to the industry median value as in Gompers et al. (2003) since service and financial companies invest less in fixed assets than highly capital intensive basic industrial companies. Industry classifications are based on the Global Industry Classification Standard of ten sectors retrieved through Worldscope. A finer industry classification was not used so as to have more significant median adjusted values. In addition to controlling for sector effects, we account for country differences using dummy variables.

The association between CAPEX and investor-sensitive corporate governance measures is evaluated using the following pooled OLS model:

$$
C A P E X_{i t}=\alpha_{i}+\sum_{j=1}^{J} \beta_{j} G_{0} v_{j, i t}+\sum_{k=1}^{K} \gamma_{k} C_{k, i t}+\varepsilon_{i t},
$$

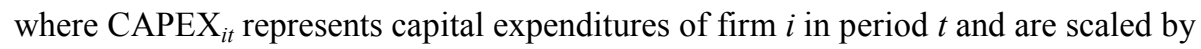
sales revenue and net of the industry median value. $C$ is a vector of $i$ control variables in period $t$. For the CAPEX regressions, these are the logarithm of price to book ratio $(\log P B)$, Tobin's $q, S G 3 Y, C F S, C R$, one-year lagged $C R$ and debt-toassets ratio $(D A)$. Furthermore, dummy variables capture country-specific differences and equal unity if a company is located in a specific country (zero otherwise). Unlike Gompers et al. (2003) we opt for a pooled framework so as to utilize the database to the fullest extent. The model also uses time-fixed effects and adjusts for heteroskedasticity (White, 1980). The reason behind incorporating $\log$ $P B$, Tobin's $q$, and three-year sales growth is that all can be interpreted as proxies for growth opportunities (Tobin's $q)$, investment potential $(\log P B)$, and capital demand (SG3Y). CFS and CR capture cash flow effects and excess cash disposal for investments. On the other hand, Gov is the variable that captures the corporate governance dimensions of firm $i$ at time $t$.

\footnotetext{
${ }^{9}$ We note, for example, that the data for the United Kingdom (unlike rest of Europe) includes listed REITs (notably British Land, Land Securities, BAA, and others), whose very high CAPEX stand in contrast to the very low financial sector median value. There are also some privatized companies, notably Railtrack PLC, and very young companies, notably RyanAir, that have invested far more than mature firms in related sectors. Inevitably, as we look closer at the data there are bound to be these extremes.
} 


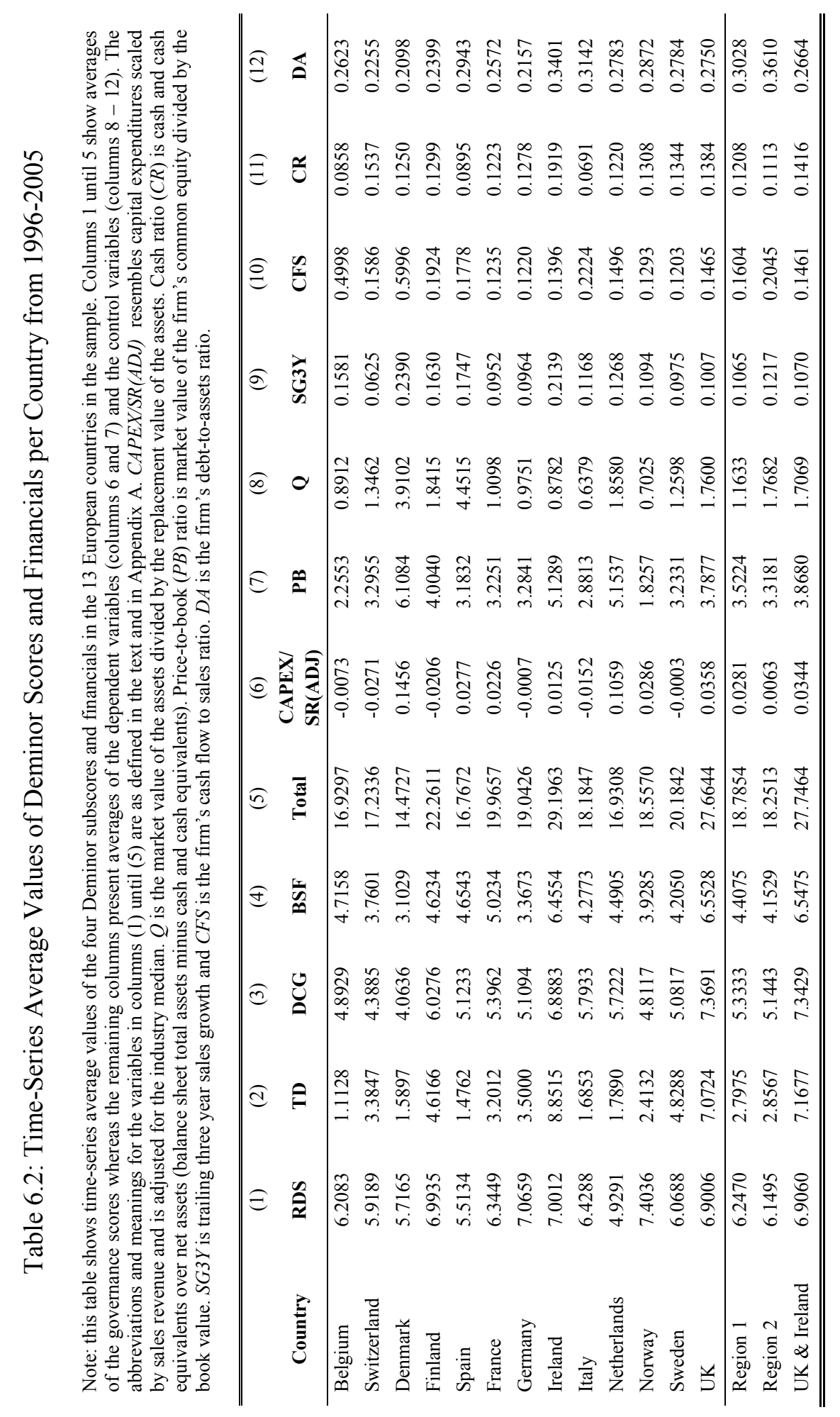




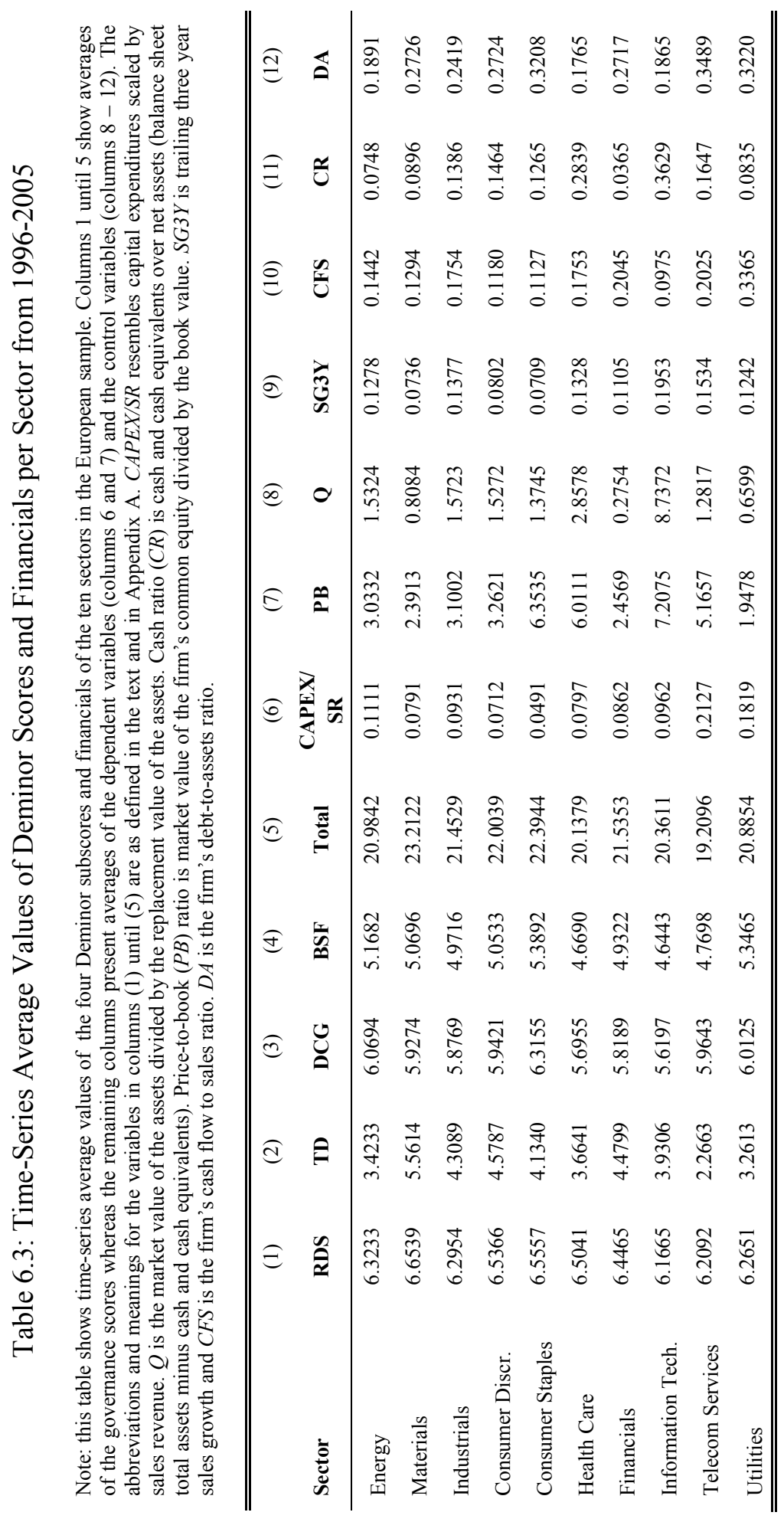




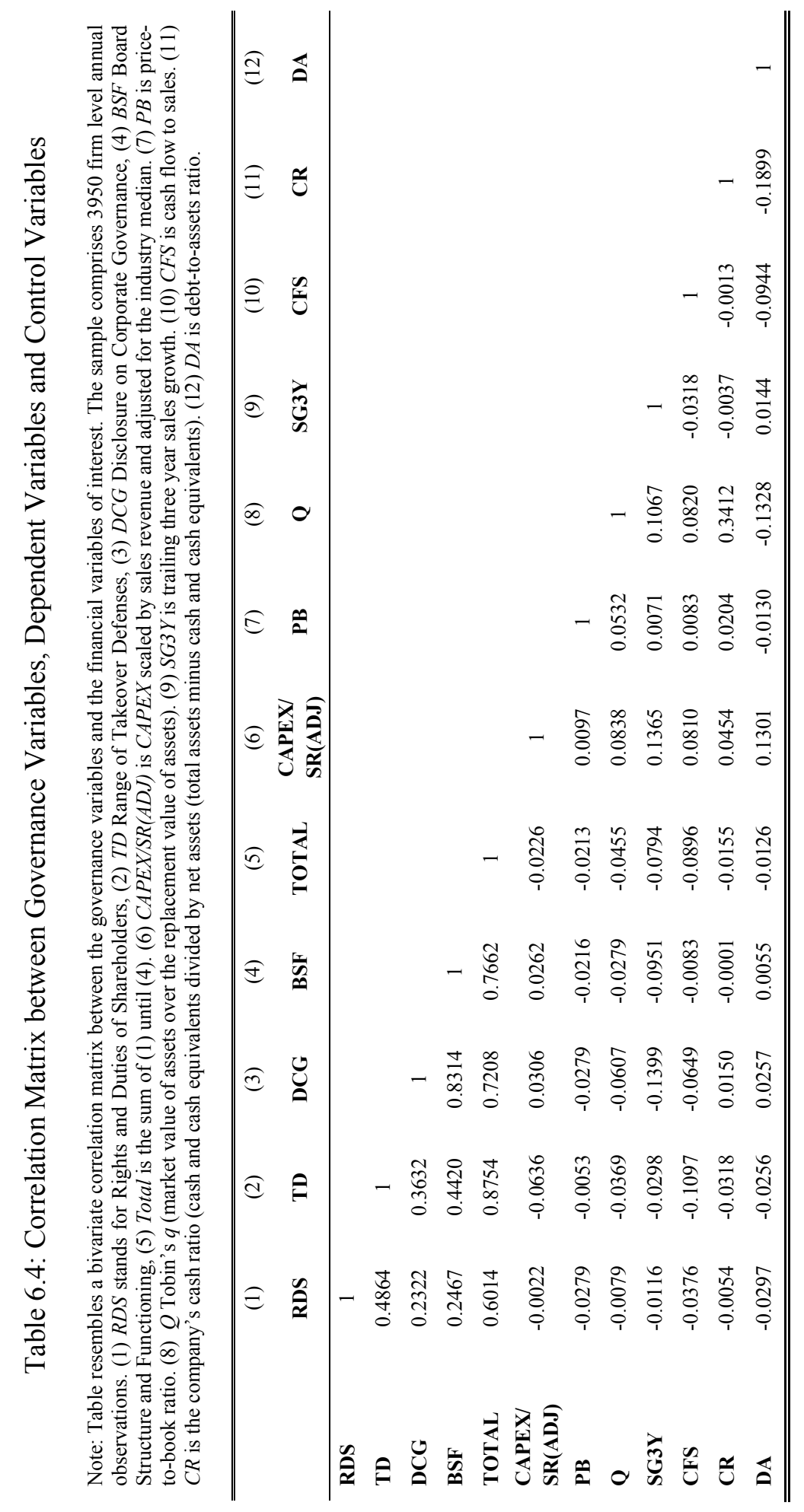


The four elements of corporate governance are highly correlated (see Table 6.4) and this limits the value of simultaneous incorporation of the variables into the regression equation. We observed a very strong correlation between the total score on corporate governance (Total) and the range of takeover defenses. On this count, this might be caused by the fact that many European companies' corporate governance are rated either lowly or very highly. Thus, a high score in this category may strongly influence the total score. Moreover, $B S F$ and $D C G$ correlate very highly with 0.83 , possibly hinting at the fact that those scores measure fairly similar items.

Potential concerns about endogeneity of corporate governance and capital expenditures are not apparent in the data. Even though one could assume larger companies (in terms of sales revenue or balance sheet total assets) would be more able to comply with international governance standards, correlations to firm size are below 0.1 . Papers investigating the endogeneity of corporate board structures have focused on the CEO's involvement in the selection process rather than the firm characteristics that may influence the selection process (see Hermalin and Weisbach 1988, 1998). In order to ensure methodological robustness, we use a cross-sectional regression approach as in Fama and MacBeth (1973) with the following model:

$$
C A P E X_{i t}=\alpha_{i}+\beta_{l} \text { Gov }_{i t}+\boldsymbol{y}_{i t} \boldsymbol{C}_{i t}+\varepsilon_{i t},
$$

Where Gov and $C$ are as outlined in the pooled OLS regression equation. The significance of the time series average is tested with a t-statistic for eight degrees of freedom. Since the results are qualitatively the same, we opted for the more powerful pooled OLS setting and report only those results.

\subsection{Results of Empirical Estimations}

Having elaborated on the databases and methodology used to test the research hypotheses, we turn to the empirical results. Table 6.5 below summarizes our expected results. Note that for some sub-aggregate scores we cannot infer the direction of statistical association. The results for the three regions are reported separately. If we observe similar effects despite different formal governance regimes and legal systems, this may be evidence for convergence in corporate management behavior in Europe. Region one including Belgium, France, Germany and The Netherlands is analyzed before we proceed to the one-tiered region two and the United Kingdom. 


\subsubsection{Findings for Region One}

This region is comprised of two-tiered systems of corporate governance and is made-up of countries with more established governance codes. Table 6.6 summarizes the regression results.

\section{Table 6.5: Research Objectives and Hypothesis Motivation}

Note: we list our expected/hypothesized statistical association of each corporate governance variable with the dependent variable (i.e. CAPEX) according to related prior studies or motivated from theory. We do not report our expected coefficients concerning the control variables since we are to our best knowledge the first to incorporate these to examine investment behavior.

\begin{tabular}{|c|c|c|c|}
\hline Category & $\begin{array}{c}\text { Expected } \\
\text { relationship }\end{array}$ & $\begin{array}{l}\text { Actual } \\
\text { relationship }\end{array}$ & $\begin{array}{l}\text { related literature/ } \\
\text { hypothesis motivation }\end{array}$ \\
\hline 1. Total & $?$ & - & $\begin{array}{l}\text { Offsetting effects within categories might blur the } \\
\text { overall effect on } C A P E X \text {, no inference on direction } \\
\text { of causality }\end{array}$ \\
\hline 2. $R D S$ & $-1+$ & $+/ ?$ & $\begin{array}{l}\text { Related to Gompers, Ishii, and Metrick (2003); } \\
\text { difference is the European market and focus on } \\
R D S \text { only. Therefore as such previously not } \\
\text { investigated. }\end{array}$ \\
\hline 3. $T D$ & - & - & $\begin{array}{l}\text { More takeover defenses lead to less pressure to } \\
\text { create shareholder value as a barrier to being taken } \\
\text { over. More entrenched managers fear losing their } \\
\text { job less. }\end{array}$ \\
\hline 4. $D C G$ & $-/ ?$ & $-1+$ & $\begin{array}{l}\text { Not investigated before; no causality inferred. } \\
\text { Directors more accountable for their decisions }\end{array}$ \\
\hline 5. $B S F$ & - & $-1+$ & $\begin{array}{l}\text { Clark, Wójcik, and Bauer (2006); Wrigley and } \\
\text { Currah (2003); notion that lax internal controls give } \\
\text { leeway in CAPEX. More frequent and rigid } \\
\text { controls and audits lead to fewer investments in } \\
\text { absolute terms. }\end{array}$ \\
\hline $\begin{array}{l}\text { Regional } \\
\text { differences }\end{array}$ & no & hardly & $\begin{array}{l}\text { Wójcik (2006), Coffee (2005) and Hebb (2006) } \\
\text { show differences between governance systems and } \\
\text { a trend towards convergence. }\end{array}$ \\
\hline
\end{tabular}

Table 6.6 reveals highly negative and significant results for Deminor's Total governance score, the range of takeover defenses $(T D)$, disclosure on corporate governance $(D C G)$, and board structure and functioning $(B S F)$. This suggests that these elements of corporate governance negatively affect capital expenditures in excess of the industry median. Hence, companies with less takeover defenses, companies which are more transparent, and companies with better internal controls 
invest less than their industry peers. Moreover, a high overall score on the quality of corporate governance contributes significantly to a reduction of CAPEX. What is remarkable, and contrary to expectations and prior research, is the positive coefficient on $R D S$. The multivariate regression involving all four governance variables confirms these findings. The lack of significance of $D C G$ in model 6 is possibly attributable to a high correlation with $B S F$.

\subsubsection{Findings for Region Two}

Having observed the results of the two-tier region one, we turn to the results for region two. Section 4.1 revealed negative effects on almost all corporate governance variables using industry-adjusted CAPEX. Recall that region two was constituted by one-tier governance systems drawn from continental European countries with recently established codes of corporate governance (see Table 6.1).

Table 6.7 reveals that region one findings are shared, to some extent, with region two. The Total's coefficient is not significant but is still slightly negative. The range of takeover defenses (TD) also bears a negative and significant effect in region two. This is manifested by the p-value which is below $5 \%$. Remarkably, both $D C G$ and $B S F$ are positive and significant, which stands in stark contrast to region one. Results from the multivariate regression equation are somewhat different. Even though $D C G$ is still positive, $B S F$ is now negative and not significant whereas $R D S$ is positive in this regression as it is in region one. We note that the model's fit in this region is better than region one.

\subsubsection{Findings for the United Kingdom and Ireland}

We have noted the different effects of $R D S, D C G$ and $B S F$ on capital expenditures in region one and region two. The coefficients on the two latter variables are opposite to what was observed for region one. Here, the results for the United Kingdom and Ireland are summarized. If we observe similar effects on overall governance as in regions one and two, we could interpret this as evidence of European convergence in corporate behavior. Table 6.8 summarizes the results of the regressions.

As observed in the previous results for the UK the Total coefficient is negative and significant. The coefficient on the rights and duties of shareholders is again positive but not significant. Confirming the findings from regions one and two, a high score on the range of takeover defenses has a negative impact on capital expenditures. $D C G$ and $B S F$ have negative and significant effects on capital expenditures. 


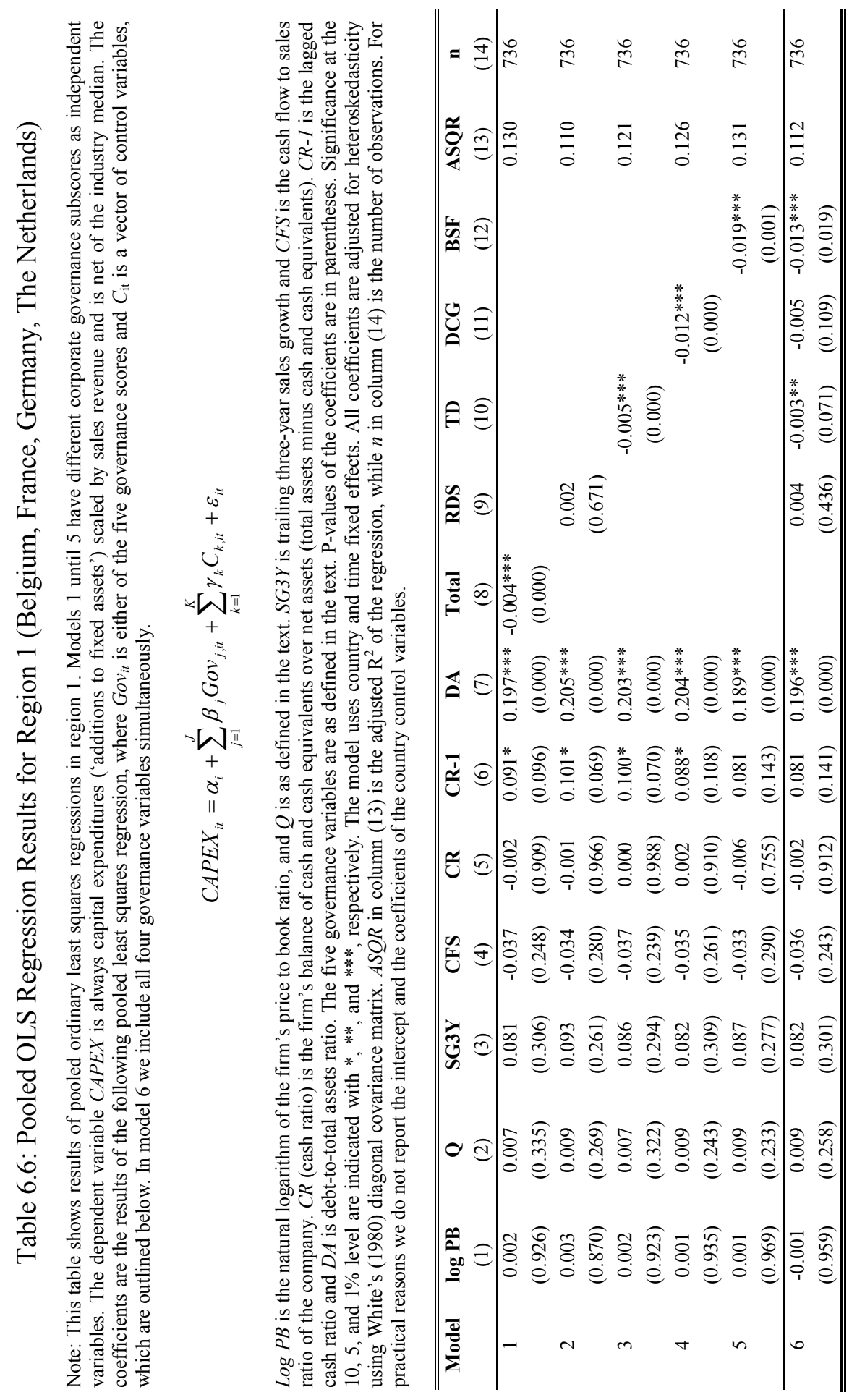




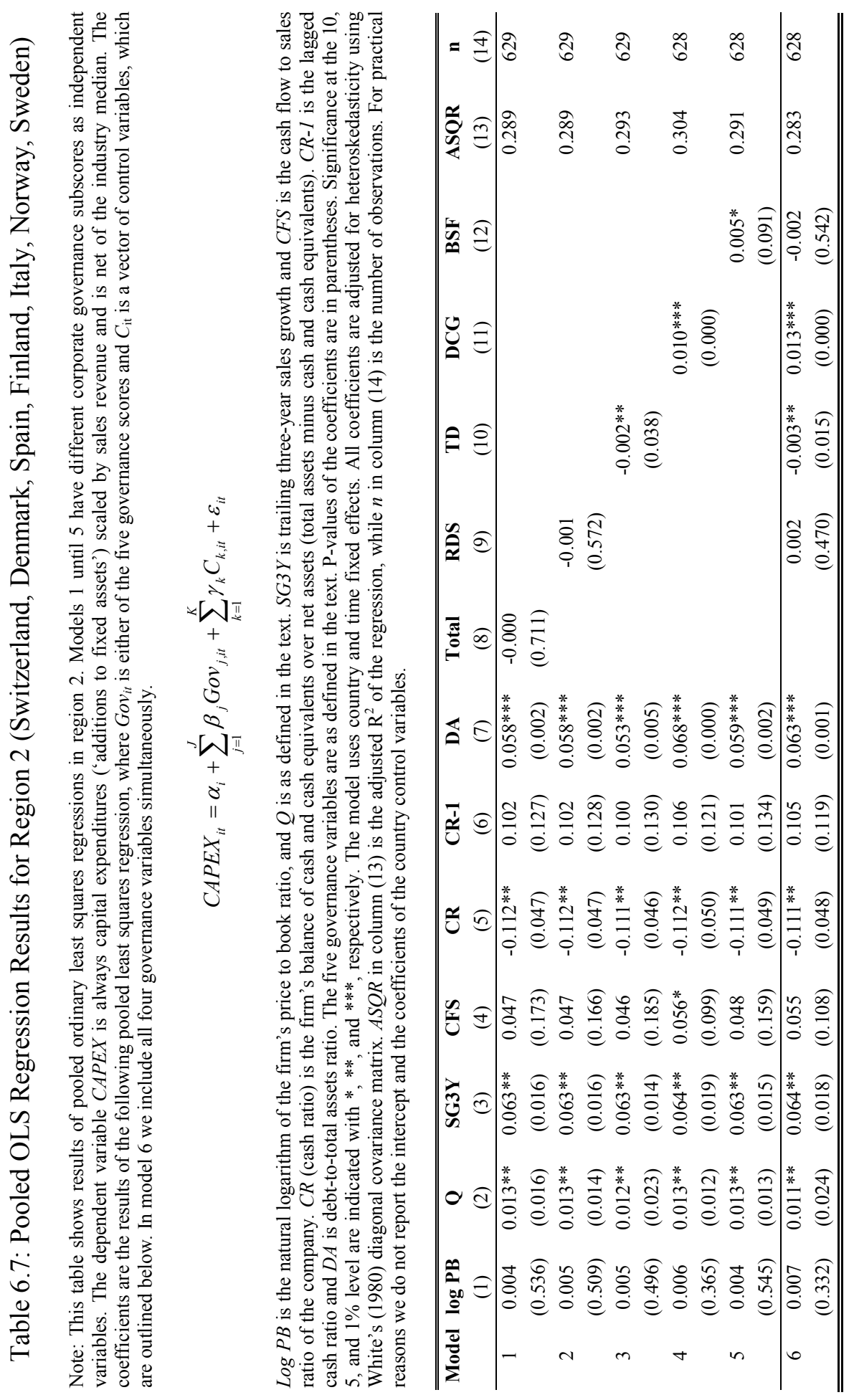




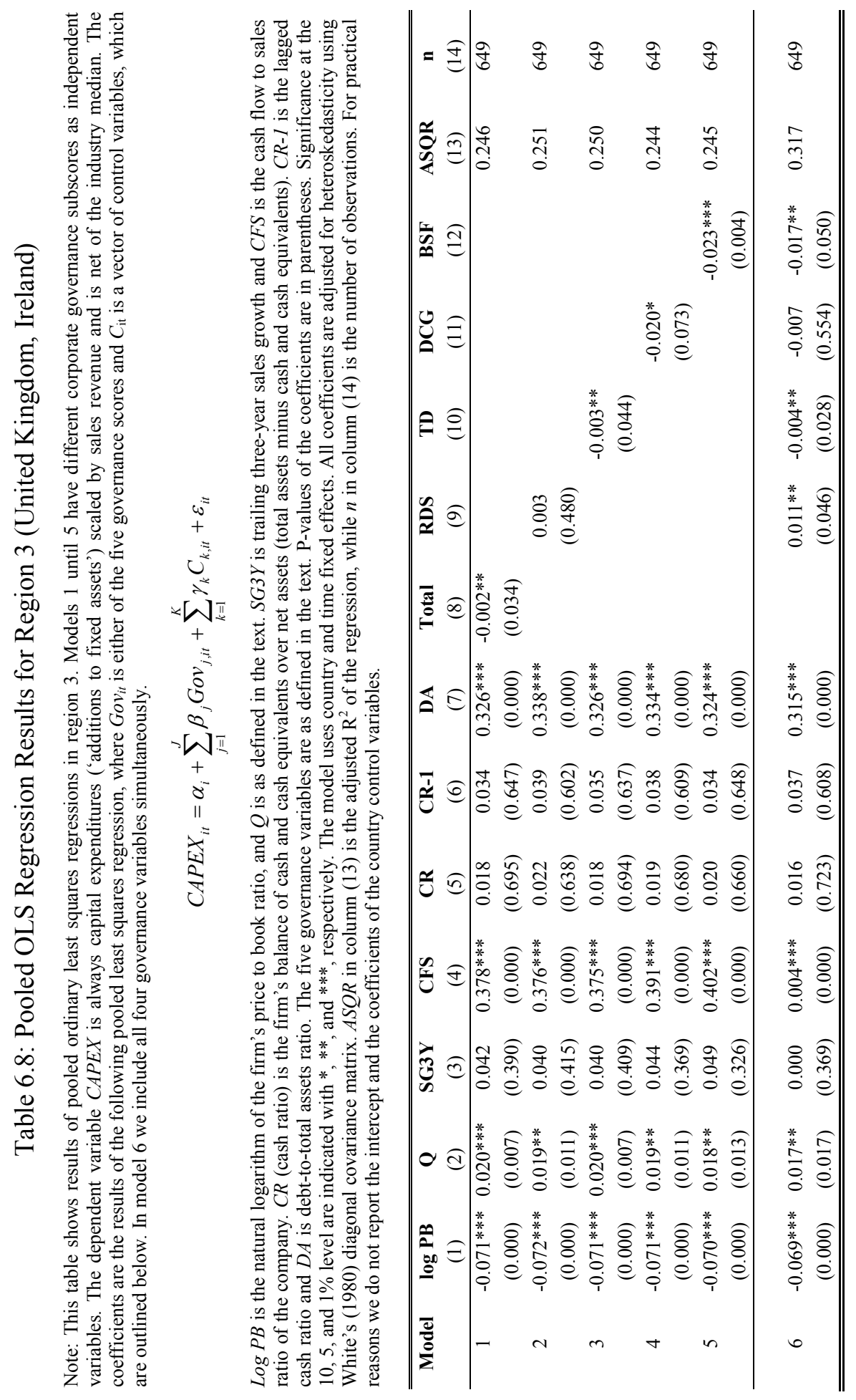


Results from model 6 strongly confirm these results. RDS is positive and significant in the multivariate regression, even though DCG loses its significance. In sum, the results from region three are more similar to region one than to region two. Furthermore, the range of takeover defenses and the Total governance score have consistently negative effects on CAPEX. Given the similar effects on this coefficient in regions one and two, we can suggest that there has been pan-European convergence in management behavior with respect to shareholder value and investment.

\subsubsection{Robustness Checks}

In order to examine how the distinction between region one and region two may affect our results, we tested the model for the whole of continental Europe. ${ }^{1}$ The results are shown in the following table. We observe that the same effects hold for regions one and two combined. The $R D S$ coefficient appears to drop-out in this grouping since the effect is inconclusive and far from conventional significance thresholds. The significance of the range of takeover defenses persists with a very low p-value. $D C G$ and $B S F$ continue to be negative and significant. The overall coefficient on Total is also negative and significant. In model 6, we note that the $R D S$ coefficient becomes more significant. Therefore, we conclude that the effects of region one dominate region two especially in the area of disclosure and board structure and functioning since the overall effect is negative. These findings are confirmed when the United Kingdom and Ireland are added to the sample. ${ }^{2}$ The effect of $R D S$ between the regions is apparently cancelled-out, which renders this coefficient insignificant. $T D$ still has a significantly negative effect, as does the Total coefficient. $B S F$ and $D C G$ are highly significant and negative. In the multivariate regression, the $R D S$ effect becomes positive and significant again, while $T D$ remains to be highly significant.

As an additional check on the robustness of the aforementioned findings, the analysis was conducted excluding financial companies (every company in the sample with a GICS code of 40$)$. Financial companies constitute a large part $(\sim 20 \%)$ of the dataset and might behave differently in terms of investment and some ratios are less straightforward to interpret (e.g. $\log B M$ ). The financial sector invests less in fixed assets than most other industries. Nevertheless, excluding financials and conducting the same analysis as shown in Table 6.10 hardly changes the results.

\footnotetext{
${ }^{1}$ We also tested to any differences in the results by subperiods. This is difficult given the fact that $1997-$ 2000 would include three static years of governance data. Nevertheless, the results were negative but weaker for 1997-2000 compared to 2001-2005.

${ }^{2}$ We do not report results of this analysis but they are available upon request.
} 

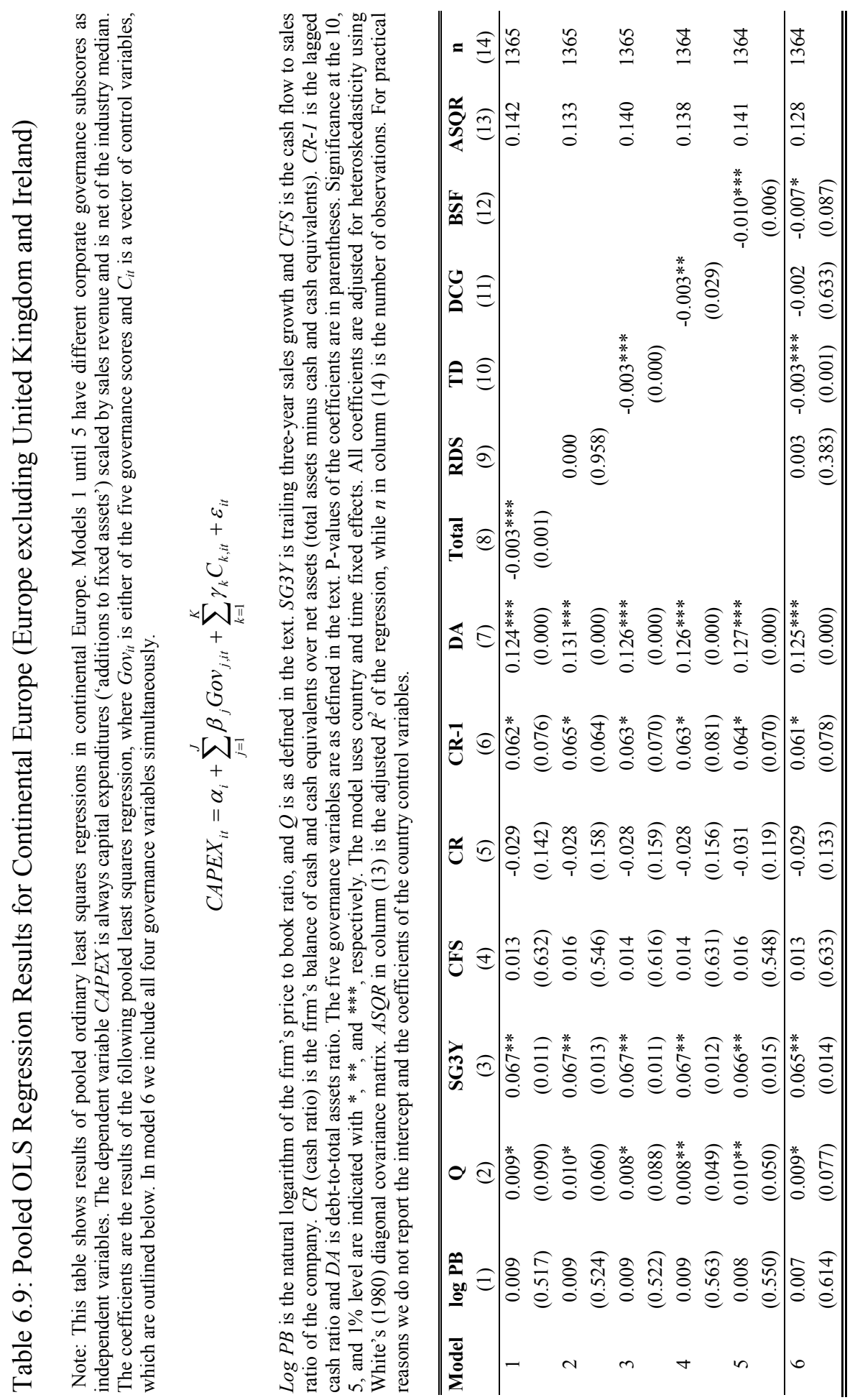


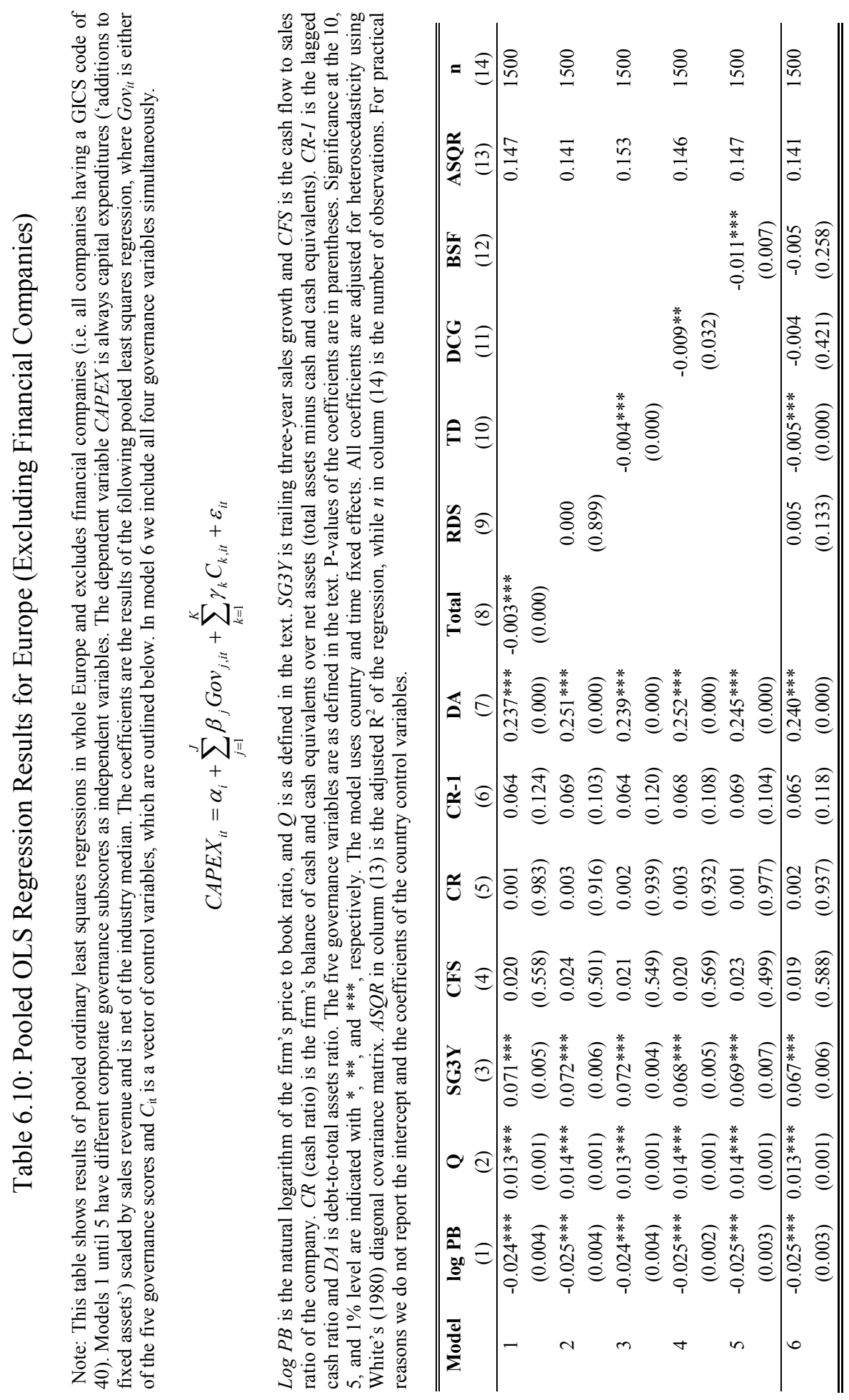


The Total governance score still has a highly significant coefficient with a p-value below $0.1 \%$. The same finding holds for the range of takeover defences and $B S F$ with p-values below $1 \%$. The $C G$ coefficient is significant with a p-value between $1 \%$ and $5 \%$. We observe a significantly positive coefficient the rights and duties of shareholders. Therefore, the inclusion of financial companies did not materially affect the results. Overall, the range of takeover defenses has a consistently negative and significant effect on industry adjusted capital expenditures. But we also observe different effects of $D C G$ and $B S F$ between the regions. The coefficient on the rights and duties of shareholders is positive but not significant. ${ }^{1}$

\subsubsection{Generalized Methods of Moments}

A potential concern in our analysis of the governance effect on capital expenditures is the of potential serial correlation in the residuals. ${ }^{2}$ This might cast doubt on the validity of OLS regressions since significance could be achieved by CAPEX hardly changing over time. In order to tackle this possible problem, we adopt an instrumental generalized methods of moments (GMM) approach as in Cochrane (2001) and Campbell, Lo, and MacKinley (1997). Unlike OLS or maximum likelihood estimation, GMM does not require the data generating process to be known. In order to estimate the parameters $\theta$, GMM can infer from sample moments to population moments without requirements such as the absence of heteroskedasticity or serial correlation. Hence the adoption of GMM results in very powerful and robust estimates. The general equation that minimizes the criterion function $q$ is as follows:

$$
q=\bar{m}(\theta)^{\prime} W_{n} \bar{m}(\theta)
$$

where $W$ (weighting matrix) is proportional to the variance of the moments $m$. Hence, the optimal weighting matrix equals $W_{G M M}=\left\{\operatorname{Asy} \cdot \operatorname{Var}\left[\sqrt{n} * \bar{m}_{n}(\theta)\right]\right\}^{-1}$. As instruments, we chose lagged values of the control variables in order to overidentify the moment equations $\bar{m}(\theta)$. As GMM weights we employed period weights and still account for heteroskedasticity using White's correction. Using this approach does not materially affect our results. ${ }^{3}$ We conclude that our findings are robust with respect to potential serial correlation in the error terms.

\footnotetext{
${ }^{1}$ We also conducted tests for the period of 2000-2005 and concluded that the backfilling procedure does not significantly statistically affect our results.

${ }^{2}$ We are grateful to Rik Frehen for suggesting this approach.

${ }^{3}$ Tables and results are available upon request.
} 


\subsection{Practice of European Corporate Governance}

Do more transparent companies with better internal controls and less takeover defenses invest less than their industry peers? Our results provide evidence that these elements of investor-sensitive corporate governance have significant negative effects on the capital expenditures of European companies. Moreover, we find, by and large, the same effects across the three European governance regions that are used to test for systemic regime effects. For portfolio investors dependent upon global financial markets for management discipline, there is a significant negative coefficient on the range of takeover defenses across all regions and in the aggregate pan-European sample. This particular score is more comprehensive than the Gompers, Ishii, and Metrick (2003) G-score since it incorporates ownership and capital structure. These findings are in-line with related findings by Daines and Klausner (2001) who point out that anti-takeover provisions increase agency costs. Moreover, they conclude that the return on investment is largest when the firm concerned has been subject to a hostile takeover. By their assessment, openness to the market for corporate control induces management to operate more efficiently (hence the $T D$ negative coefficient).

Intriguing results were also found for the coefficients on disclosure and board structure and functioning $(B S F)$ : it was shown that these coefficients had persistently negative effects on industry-adjusted CAPEX in region one and region three. While the former category refers to the transparency of firm governance, the latter variable captures the independence, the insider/outsider mix, and the committee formation of the board - consequently, the governance potential of a firm in relation to investment decision-making. Recall that poor board functioning and a lack of internal control systems were the governance failures that allowed empirebuilding at Royal Ahold. Less transparent governance allows management to exploit the ambiguities inherent in any governance regime and can allow managers to conceal value-destroying projects and perks.

Whereas our BSF's result matched our theoretical expectations of a negative relationship, in Table $6.5 \mathrm{DCG}$ 's negative coefficient was not inferred previously. Similarly, the positive coefficient on the rights and duties of shareholders is a finding that does not appear in prior research and may appear odd. Recent academic discussion reveals that the role that the rights and duties of shareholders may play in corporate governance is rather ambiguous. Some legal scholars argue that "active investor involvement [...] disrupts $[. .$.$] the centralization$ of essentially non-reviewable decision making authority in the board of directors" (Bainbridge 2006). The coefficient on $D C G$ is not significant in all settings and a deeper exploration is required in further research. 
Most importantly, our results have significant implications for understanding the nature and performance of competing European regimes of corporate governance. The study focused on three distinct European regions and investigated the relationship between corporate governance and shareholder value in each region and then across Europe. The overall effect of corporate governance (the Total score) on CAPEX is consistently negative. Results are very similar across the regions and in the pooled sample even though the underlying formal structures of corporate governance are quite distinct by nation-state. This result implies that managers of large firms tend to respond to common investor-driven standards of corporate governance irrespective of their home of incorporation. Apparently European companies opt less for retained earnings and more for the AngloAmerican approach of distributing excess cash flow to shareholders with variable payout ratios (compare Dore, 2000).

In effect, our results suggest that whatever the formal design and structure of a country's model of corporate governance, portfolio investors are able to exert pressure on the managers of large firms to act in ways consistent with shareholder value rather than stakeholder value (short-term rather than long-term value). This is an important finding since it tends to discount the significance of national rules and regulations in the face of global financial market imperatives (as suggested by Clark and Wójcik 2007).

In this regard, the most important governance effect was found for the variable that is the least regulated among the four categories throughout Europe, namely the range of takeover defenses $(T D)$. Even though EU recommendations to abstain from the use of anti-takeover measures exist, regulations to this effect hardly ever appear in European countries' corporate governance codes. ${ }^{4}$ The Spanish Aldama Report (2003), for example, points out that "the adoption of protective measures aimed at preventing takeovers [...] should also require the approval of the Shareholders' Meeting" (Section IV, 1.3). This constrains incumbents' ability to entrench but does not prohibit this behavior. Likewise, the Dutch Tabaksblat code (2003) does not include "best practice provisions on the permissible use of antitakeover measures in (hostile) takeover situations" (Section 56-59). Other governance codes of the countries in our sample do not address takeovers or merely recommend the procedures concerning the submission of takeover bids.

\footnotetext{
${ }^{4}$ In the EU, the 2004 Directive on takeover bids (Official Journal L 142, 30/04/2004) seeks to encourage the "proper functioning of financial markets" requiring (Article 3) that company boards "must act in the best interests of the company as a whole" when considering takeover bids while (Article 11) denies the use of defensive measures in such circumstances. However, it is also widely appreciated that the Directive (Article 12) also allows member-states the right to not require companies to comply with these regulations.
} 
Hence, the European market for corporate control is only loosely regulated but perhaps underestimated in terms of its effect on management behavior. That this result is strongest in region three is not surprising since the UK is characterized by a high degree of dispersed ownership and a relatively liquid stock market. Therein, the market for corporate control is an important disciplining force for managers of this region. Region one is made up by countries where transparency and objective board functioning have been heavily promoted recently. This might explain these variables' strong effects on CAPEX.

A further surprising finding is the positive and significant coefficients on $D C G$ and $B S F$ in region two. Apparently, companies incorporated in one-tier structured countries with recent governance codes invest more the more transparent they are and the more independent board and internal controls are managed. This result is opposite to that in regions one and three. However, when combining region one with region two in a pan-European sample, we note that the negative effects on these variables dominate the positive effects. Further, a negative effect for both $T D$ and Total in a region with different board structures a different legal system and a less established governance code gives in our view even stronger evidence of convergence in the practice of corporate governance. Returning to our question, whether the Anglo-American or the continental European approach dominates manager behavior, we clearly reject the latter. It seems that market-related elements of corporate governance have the effect of disciplining managers to distribute revenue rather than retain earnings.

\subsection{Conclusions}

Using a unique database on the governance ratings of European companies from 1997-2005 provided by Deminor, and combining it with financial data from Worldscope, we were able to establish a statistically significant negative relationship between investor-sensitive corporate governance and company investment. This is stronger in the continental European region that comprises predominantly two-tier structured companies whereas the unitary board region has a weaker but still consistent result. The results for the UK and Ireland are stronger in magnitude and were in the same direction. Here, the disciplining effect of the market for corporate control is especially pronounced. The effect still holds even if we pool all companies together into a pan-European dataset. In effect, the Anglo-American governance system serves as a market-reference point for the governance of large continental European firms. Robustness checks such as excluding financial companies do not alter our results. Moreover, we are able to show that our results are robust even in the case of serial correlation. 
In light of the fact that European policymakers have sought to 'reform' companies' governance structures by the introduction of governance codes, it is interesting that the least regulated element - the range of takeover defenses - is the most significant element disciplining corporate managers. Companies adopting fewer anti-takeover provisions spend significantly less than their industry peers. This suggests that the global market for corporate control is underestimated in terms of its disciplining effect on corporate managers. Equally, this suggests that theorists of corporate governance that emphasize the inherited governance traditions of nation-states may over-estimate the significance of formal regulatory structures. In effect, our results suggest that as global financial markets continue to integrate, and as portfolio investment managers expand their interests to the four corners of the globe, market-standards of governance may come to dominate formal regimes of governance in ways that discount the significance of the latter.

This conclusion, though tentative and obviously specific to our research, is underpinned by related findings with respect to companies' disclosure practices and the quality of board structures and their functioning. We are able to show that the more transparent are the governance practices of companies the less likely managers invest beyond the industry median. Similarly, our results suggest that betterfunctioning boards arrive at more market-sensitive investment decision-making. Therefore, the European market for corporate governance can serve as a substitute for national governance codes and regulations if companies converge to AngloAmerican practices so to appeal to the interests of institutional investors. Our analysis provides evidence to the effect that European companies increasing focus upon short-term shareholder value in ways consistent with Anglo-American practices.

Of course, our results should be treated with some caution. In their paper, Gompers et al. (2003) note that their G-score, which is constructed by enumerating entrenching- and anti-takeover devices, can be a symptom of corporate culture rather than management behavior. Thus, a low score on corporate governance need not necessarily be a consequence of management's intentions but can also be determined by (unknown) external variables. The authors also note that there might be some "hardly quantifiable variable" that determines corporate governance structures apart from managers' entrenchment motives. Similarly, an omitted-variable bias might affect our results if the variable is correlated with either of the regressors under examination. That is, CAPEX might also be driven by some other variable beyond being a value- or a growth stock $(\log B M)$, realizing growth opportunities (Tobin's $q)$, or satisfying investment demand $(S G 3 Y)$. Since we followed prior researchers' arguments and intuition, we are confident that we control for the most obvious factors. 
Some critics oppose the increased reliance on commercial databases that quantitatively rate firms' corporate governance structures and construct metrics out of qualitative information. Sonnenfeld (2004) argued that rating companies rely on myths rather than evidence in arriving at objective judgments. However, our use of the Deminor data is premised upon our own knowledge and experience with the data and our assessment of the skills and expertise of their team of specialists. In any event, we note that the database is used extensively by institutional investors to make their investment decisions. Even if the database were misleading on crucial issues, it is more robust than the method used by Gompers et al. (2003) and has the added virtue that it is, in fact, data which actually affects global investment decisionmaking. 


\section{Appendix A - Description of Deminor's rating algorithm}

The research enables the user to compare corporate governance standards and practices across companies with reference to four corporate governance categories (see Deminor Ratings S.A. Brochure, p. 5. Brussels, Belgium. Retrieved August 05, 2005 from the World Wide Web: www.deminor.org

Rights and duties of shareholders $(R D S)$ - Includes criteria concerning the respect of the one-share one-vote one-dividend principle, voting right restrictions, voting issues, shareholder proposals, voting procedures and maintenance of pre-emptive rights

Range of takeover defenses (TD) - Examines the presence and strength of antitakeover devices such as poison pills, golden parachutes, core shareholdings, extensive cross-shareholdings and co-option systems that could be used to protect the company from a hostile takeover and to disenfranchise shareholders. Further to this, the dilution effects and economic barriers to such instruments are examined.

Disclosure on corporate governance (DCG) - Analyses the transparency of a corporation as measured by the quantity and quality of non-financial information on its governance structure such as diversity and independence for board members, board committees, director remuneration, auditors' fees and rotation, accounting standards, information on major shareholders of the company, environmental Information, etc.

Board structure and functioning $(\boldsymbol{B S F})$ - Examines all issues relating to the governance of a board such as independent directors, division of the role of the chairman and chief executive, election of the board, director remuneration, the workings and authorities of board committees, etc. 


\section{Appendix B - Description of Control Variables}

Note: we define the control variables that we use throughout our statistical analysis. All of the data was taken from Worldscope. Since the statistical analysis makes exclusive use of ratios, we do not have to tackle currency effects between the European countries under investigation.

(1)

\begin{tabular}{|c|c|c|}
\hline Abbreviation & Variable & Description \\
\hline PB & Price-to-book ratio & $\begin{array}{l}\text { Price-to-book current - Price-Current / Book Value Per } \\
\text { Share }\end{array}$ \\
\hline SG3Y & $\begin{array}{l}\text { Trailing three-year } \\
\text { sales growth }\end{array}$ & $\begin{array}{l}3 \text { YR ANNUAL GROWTH represents ((Current Year's Net } \\
\text { Sales or Revenues / Net Sales or Revenues four years ago, } \\
\text { reduced to a compound annual rate) }-1) * 100\end{array}$ \\
\hline Q & Tobin's $q$ & $\begin{array}{l}\text { TOBIN'S Q - it is the market value of assets divided by the } \\
\text { replacement value of assets. The market value is } \\
\text { approximated by the difference between the sum of the book } \\
\text { value of assets and the market value and the book value of } \\
\text { equity. The replacement value of the assets is simply the } \\
\text { book value of assets }\end{array}$ \\
\hline CFS & $\begin{array}{l}\text { Cash flow to sales } \\
\text { ratio }\end{array}$ & $\begin{array}{l}\text { CASH FLOW TO SALES represents Funds from } \\
\text { Operations / Net Sales or Revenues } * 100\end{array}$ \\
\hline CR & Cash ratio & $\begin{array}{l}\text { Cash ratio - as defined by Dittmar and Smith (2007): cash } \\
\text { and cash equivalents divided by net assets (total assets minus } \\
\text { cash and cash equivalents) }\end{array}$ \\
\hline debt & $\begin{array}{l}\text { Balance sheet total } \\
\text { debt }\end{array}$ & $\begin{array}{l}\text { TOTAL DEBT represents all interest bearing and } \\
\text { capitalized lease obligations. It is the sum of long and short } \\
\text { term debt. }\end{array}$ \\
\hline TA & $\begin{array}{l}\text { Balance sheet total } \\
\text { assets }\end{array}$ & $\begin{array}{l}\text { TOTAL ASSETS represent the sum of total current assets, } \\
\text { long term receivables, investment in unconsolidated } \\
\text { subsidiaries, other investments, net property plant and } \\
\text { equipment and other assets. }\end{array}$ \\
\hline SR & Sales revenues & $\begin{array}{l}\text { NET SALES OR REVENUES represent gross sales and } \\
\text { other operating revenue less discounts, returns and } \\
\text { allowances. }\end{array}$ \\
\hline CAPEX & $\begin{array}{l}\text { Capital } \\
\text { expenditures }\end{array}$ & CAPITAL EXPENDITURES - Additions to fixed assets \\
\hline Country controls & & $\begin{array}{l}\text { Country dummy - variable equals one if company belongs } \\
\text { to a particular country and is zero otherwise }\end{array}$ \\
\hline
\end{tabular}





\section{Chapter 7}

\section{Conclusion}

The insights of this doctoral thesis shed new light on instances of stock market manipulation. That is, the ability of market participants to make use of international securities markets for public corporations in the presence of asymmetric information. Much of the work has been inspired from the literature on signaling and from both early evidence on agency relationships between managers and shareholders and more recent support on conflicts of interest between firms and financial intermediaries, such as underwriting investment banks. The theoretical and empirical evidence on diverging interests between managers and shareholders is overwhelming. Still, the question whether this enables rent-seeking by corporate decision-makers or whether we observe permutations of optimal contracting remains by and large unanswered.

The academic literature is largely divided on the question of managerial compensation. Whereas popular work by Bebchuk and Fried and most of David Yermack's contributions condemn "pay without performance" (2004), "flights of fancy" (2006a), "golden handshakes" (2006b), and "deductio ad absurdum" (2009), respectively, a camp of researchers finds less unanimous answers. Since Gabaix and Landier (2008), Edmans, Gabaix, and Landier (2009), and Edmans and Gabaix (2009) the discussion about optimal contracting in CEO compensation has been refueled. In a nutshell, CEO pay is simply a function of increasing firm size, growing competition in the market for managerial talent, or ramifications of managerial talent and human capital itself. As a consequence, CEO pay has not increased six fold since 1980 because CEOs are six times as greedy but more because corporations are six times larger and more valuable.

In order to be eligible for this compensation, managers have to comply with duties and to steer corporations for the maximization of shareholder value. In an 
international context, other stakeholders also have to be taken into account conditional on the prevalent governance system. This dissertation provides evidence on 1) how this shareholder (stakeholder-) value maximization done in an international context and which role institutional investors play and 2) the consequences of violations of fiduciary duties. Lastly, this research applies the setting of agency conflicts and asymmetric information to primary securities markets and explores the role of the investment bank and financial regulation. In the following subsection, I will reflect on every chapter's result with respect to the broad implications and avenues for future research.

\subsection{Summary of Main Findings}

The consequences for managers violating their fiduciary duties or market participants acting in self-interest are an escalating degree of litigation risk from outside shareholders and external parties. How this behavior affects long-term performance and corporate behavior is the focus of this dissertation. In hypothesis 1 of Chapter 2, I conjecture that individual directors can be disciplined by the filing of class-action lawsuits, whereas entire corporations cannot. This effect manifests into a long-term reversal of underperformance into outperformance for holding periods beyond 12 months. This effect is restricted to cases where individual directors have been sued for violation of duty of loyalty (insider trading, related party transactions). On average, the filing of a class-action lawsuit is a disruptive event but does this put the firm into financial distress? I do not find evidence of this to occur in hypothesis 3. In fact, expected default probability decreases after the filing of a lawsuit even though this risk is still more pronounced than the unconditional probability established by prior researchers (Bharath and Shumway, 2008). My results are also not an artifact of firms in the sample, which have already been facing problems before the actual filing of a lawsuit. In hypothesis 2, I do not find evidence that performance effects differ substantially between firms experiencing triggering events and firms that do not. The chapter acknowledges that a naïve approximation of KMV's distance to default is only one way of measuring bankruptcy risk, default probability, and possible financial distress. Bond and/or issuer credit ratings are supposedly more reliable with the drawback that they can only be implemented for two-thirds of my sample. Moreover, rating agencies face potential conflicts of interests as well due to the "issuer pays" system (Richardson and White, 2009). Chapter 2 therefore proposes and implements a cleaner and more unbiased solution to measuring financial health and solvency of corporations.

Chapter 3 suggests a different interpretation to the occurrence of classaction lawsuits: they are shareholders' response to dysfunctional out-of-equilibrium behavior of managers. Concerning monitoring and executive compensation, shareholders face various trade-offs. Shareholders neither have the power to enforce 
governance changes nor find more efficient compensation schemes than insiders themselves. Moreover, the benefits of remuneration in the form of stock options are pervasive. The consequence is that insiders find themselves in managerial discretion. Glitches in the corporate governance system and dispersed share ownership enable this purportedly problematic behavior of insiders to increase firm risk due to their stock option incentives. The solution to this problem is the existence of shareholder litigation: both as an ex ante threat and as an ex post "punishing" device. Since the filing of lawsuits is costly, the quest for more cost-efficient alternatives is intriguing. I find this in the passage of Sarbanes-Oxley Act (SOX) personal liability section in 2002. From that point onwards, CEOs could be held liable to a higher extent than before, which deters problematic behavior from option incentives in the presence of managerial discretion. On a macro level, compliance with SOX has been criticized for being increasingly burdensome and to put the U.S. stock market at a comparative disadvantage for newly listed (especially foreign issuers) vis-à-vis financial centers such as London, Paris, and Frankfurt (Doidge, Karolyi, and Stulz, 2009). On a micro level, SOX bears advantages for shareholders to enforce corporate control and to curtail managerial self-interest. For managers and companies, a higher risk of personal liability and litigation risk could render the U.S. as a less preferred place of business. More research from the strand of literature from economic geography is needed for that.

Chapter 4 switches from the agency relation between shareholders and managers to agency conflicts between companies and financial intermediaries. This is a timely and important research area. I adopt a setting of primary securities issuance markets and supposed cases of market manipulation during the hot issue market of 1998-2000. In the chapter I give an answer to the paramount degree of underpricing at the end of the 90s, which has exceeded levels far beyond what conventional models of IPO underpricing can explain. A suggestive answer is already provided in Loughran and Ritter (2004) but I look at the practice of "laddering" in greater detail. The underwriting investment bank makes use of its reputational capital and underprices in order to attract investors ("ladderers") into tie-in agreements, which they can secure a bigger allotment with. This is also to transfer the role of aftermarket price stabilization to the ladderers. The underwriting financial conglomerate further provides reinforcing price stabilization through its asset management arms. Unfortunately, I cannot prove the existence of commissions in the form of kick-back schemes but is fair to assume that the generation of these "soft-dollars" exists. In summary, the paper gives answers to how financial intermediaries can use information asymmetry and agency conflicts in financial markets for their own benefit. Financial regulators are largely powerless in curtailing these practices because powerful market participants are likely to change the rules of the game in response to regulation. 
Chapter 5 and 6 return to the shareholders' perspective again. In Chapter 5, I study the extent and the triggers of shareholder activism in the form of shareholder proposals and proxy voting. Shareholders respond to the absence of discipline from the managerial labor markets and market competition with the filing of shareholder proposals. To a large extent, these proposals are on compensation and incentives. On the downside however, this equity participation gives insiders the voting rights to block shareholder proposals. Potentially, this chapter offers an explanation to the valuation discount of companies in companies with high takeover defenses and concentrated industries. These companies suffer from a lack-of-control discount due to insiders' ability to block proposals, which inhibits shareholders' effective control. In the last chapter, I argue for a convergence of continental European corporate governance towards Anglo-Saxon standards due to institutional preferences of institutional investors. The response from these stock market pressures are an increasing aptitude to short-term shareholder value creation. Ultimately, the consequence of these alleged institutional pressures for managerial myopia could be adverse effects for local stakeholders. Anecdotal evidence from Nokia and Opel in Germany is undeniably supportive of this view.

\subsection{Implications of Empirical Results}

My dissertation has important implications for several parties. The first group, which is likely to benefit the most from my research, comprises shareholders. Their ability to monitor and to control managers in the presence of asymmetric information is ultimately influenced by the corporate governance landscape and the mechanisms at their disposal. According to my study, shareholder litigation and shareholder activism from proxy proposals are two of such options, which can be effective under given circumstances. Shareholder litigation is a viable option if other mechanisms have failed or are unavailable - especially for dispersed shareholders. Still, it is costly and long-term benefits should be carefully evaluated against shortterm direct and indirect costs. As proclaimed groups of active participants in the primary issues market, institutional investors but also retail investors can benefit from my findings in this dissertation. This is because they are long-term institutions, which are preferred targets in the solicitation of demand for IPO shares and the eventual allocation process. They have to be aware of the fact whether there is a rational explanation for IPO pricing and performance in the market or whether they are the product of manipulation.

For that reason, the regulator as a second group also benefits from my research. I do observe benefits from regulatory intervention in the form of the passage of Sarbanes-Oxley Act. This suggests that regulation in financial markets has been successful. But according to Chapter 4, this does not necessarily have to be the case across the board. Informational asymmetries and market frictions will 
continue to enable regulatory arbitrage and potential enrichment of more informed parties. It is therefore unlikely that regulation of financial markets by augmenting transparency of corporations, enabling a level playing field for market participants or by setting caps on executive compensation will achieve the desired outcomes.

I identify the third group of beneficiaries as corporate insiders and key decision-makers in financial institutions. The amount and the magnitude of litigation risk that they face in financial markets has substantial impacts to the decisions that they make. Especially, risk-taking propensity and the design of compensation schemes will be affected. Pre-IPO investors such as angel investors, venture capitalists, and manager founders can face the possibility that the commissioned investment bank acts in different interest. This will in turn affect the observed pricing of the IPO, the selling behavior and the post IPO performance. Chapter 4 provides indicative evidence for these variables.

The last group that my dissertation concerns is comprised of financial intermediaries in the market. Regulatory intervention by and large shapes the way in which investment banks are able to conduct their business. According to my study, there are consequences of litigation and there should be reputational penalties. The current financial crises and lessons from the past put serious challenges to the financial regulator and the social planner. The beginning of the millennium has been marked with governance scandals, which were followed by regulations on corporate governance. Although Sarbanes-Oxley was meant to curtail insider trading and concealment of material facts and to enforce disclosure rules and heighten personal liability of key decision makers, financial markets still witnessed subsequent cases of option backdating. It seems like regulated subjects behave in ways to circumvent and to mute the effects of regulation. Recent academic research has already unraveled the practice and the consequences of "lucky" option grants (Bebchuk, Grinstein, and Peyer, 2010) and option backdating (Heron and Lie, 2008, Cicero, 2009). We are unlikely to observe exactly this form of manipulation in the near future. In my view this shows the importance of academic research in this area if the outcomes are communicated in the proper way to the world of practitioners. A prominent lead example must be the pioneering work 33 researchers of the Accounting, Economics, and Finance Departments of New York University's Stern School of Business, which analyses the financial crisis and proposes solutions to prevent future systemic crises from happening (Acharya and Richardson, 2009).

I stress one final point that pertains to all the chapters, which are closely linked to corporate governance themes. Nowadays research to a large extent on the concept called "equity governance"; that is, management tries to maximize the value of outstanding claims. Since debtholders have a flat claim on the company's cash flows, this is not necessarily an issue. It does get severe in the case of subordinated 
debt when there are risk-shifting activities from shareholders to bondholders. This is what I address in Chapter 2 and 3, when risk-taking activities due to equity incentives put the company nearer towards financial distress (cf. 12.09 vs $8.95 \%$ expected default probabilities for sued versus the universe of U.S. stocks, respectively). This underscores the importance of "debt governance" in the context of managerial risk appetite. A closer alignment with the interests of debtholders is therefore pivotal to deterring situations of excess risk-shifting (Sundaram and Yermack, 2007). Anecdotal evidence for a lack of debt governance can again be found in the ongoing global financial crisis where banks (whose default is systemically relevant) have taken on too much risk, neglected subordinated creditors and (in the case of financial firms) the Federal Deposit Insurance Corporation (FDIC) as claimholders.

\subsection{Suggestions for Further Research}

Under a common and related topic, Chapter 2 and 3 give important avenues for future research in light of the financial crisis with respect managerial propensity for risk-taking due to asymmetric compensation schemes. Table 2.1 in Chapter 2 and Figure 2.1 in Chapter 3 both expose steep increases over time in response to decreasing stock markets. Since monitoring is costly for shareholders, they will be indifferent to risk-taking in times of high stock market valuations. The question that emerges from my finding is which portion of managerial risk appetite (probably induced by the compensation scheme) is necessary and in shareholders' interest and which component of this is "excessive"? Related to the effectiveness and potential of shareholder litigation in controlling managers, I have to acknowledge that the research presented in my dissertation is somewhat U.S.-centered. There are countries (e.g. Finland) in this world, where litigation risk from securities class actions is basically absent for companies. This does not mean that reputational risk from litigation risk is mute in those countries. A question deriving from these legal disparities is whether alternative mechanisms are more dominant in these countries.

A research area, which receives mounting awareness centers on conflicts of interest and coordinated behavior of financial institutions and financial conglomerates. The academic research around "forensic finance" (Ritter, 2008), Bodnaruk, Massa, and Simonov (2009) but also Bodnaruk, Braun, and Massa (2009) from this dissertation is both amplified and corroborated by anecdotal evidence from the ongoing financial crisis. Regulatory arbitrage, the "leverage game" (Acharya and Schnabl, 2009) and the credit rating agencies' roles are still largely unexplored (Richardson and White, 2009). More academic work on this is crucial for future research. From my perspective the most timely research avenues can be drawn from Chapter 4. The question about the legitimacy of tie-in agreements and the accompanying commissions business has not even been answered with the proposed 
global settlement of 586 million USD, which releases issuers and investment banks from any further liability. We could expect that the cost of settling any litigation risk does not exceed the benefits that investment banks have made from manipulating IPOs. A more fundamental question however emerges from my findings, which pertains more to the ramifications of laddering on a macro-level. If insiders (with or without explicit collusion with investment banks) and selected institutional investors seem to benefit from laddering, will it impose a dead-weight cost in the market? In other words, do uninformed investors lose more because of inflated stock prices than what initial investors, investment banks and corporate insiders could potentially gain from price inflation/stabilization? Related to this, the questions of awareness of other parties (venture capitalists) and implicit/complicit collusion seem to be important subjects to pursue further. Lastly, are tie-in agreements a practice, which involves the lead underwriter only, or is the entire syndicate involved? The answer to this question ultimately leads to acknowledging profit sharing and informational spillovers in financial markets.

With respect to one of the most researched subject areas in corporate finance, namely (the underpricing of) initial public offerings, my dissertation offers avenues for further research in the direction of conflicts of interest in the issuerunderwriter relation. On the one hand, reputation in investment banking seems to be an important asset. On the other hand, this does not get eroded from scandals: the supposedly most "active" investment banks in forensic finance are still the most reputable underwriters in our time (with the exception of Lehman Brothers for different reasons). In my dissertation I do find strong reputation effects for the filing of class-action lawsuits for corporations and for individuals - how can malpractices be with a much lesser effect for financial intermediaries?

Chapter 5 gives implications for future research with respect to the emergence of shareholder activism using shareholder proposals and proxy voting. It has to be acknowledged that the endogeneity of the (institutional) shareholder base is an incredibly tricky obstacle to overcome. Nevertheless, the ownership structure of a company has substantial effects on corporate decision-making (Bushee, 1998), takeover activity (Baker, Coval, and Stein, 2007), and even asset prices (Merton, 1987; recently Greenwood and Thesmar, 2010). Admati and Pfleiderer (2009) and Edmans and Manso (2010) have given analytical solutions to the trade-off involved in the forms of activism. Because large investors face this trade-off between becoming active monitors by selling the stock or by shareholder proposals, it is imperative to give empirical answers to what influences the choice for either form of activism. With the increasing emergence of databases, my dissertation sheds some new light on this issue but certainly more empirical work on this is needed. 
Chapter 6 focuses on international corporate governance. We can consider important avenues for future research with respect to corporate governance in emerging markets. Klapper and Love (2004) and Durnev and Kim (2005) have made considerable advances in this area but it is not clear yet in which direction corporate governance systems will develop. My research provides some evidence that the internationalization and the growing importance of the institutional investor base contribute to the fact that we are likely to see a convergence from bank-centered systems of corporate governance to market-based systems. It is however still uncertain which of the two systems firms from emerging markets will opt for due to differences in legal heritage and ownership rights (La Porta, Lopez-de-Silanes, Shleifer, and Vishny, 1998).

In summary, "stock market manipulation" as defined in this dissertation is commonly occurring in securities markets. The answer to the question whether this has had forensic backgrounds or not, is outside of the scope of this dissertation. Some practices like option backdating could effectively constitute a victimless crime but still they constitute a criminal act, which is condemned by criminal law. In essence the question of legitimacy boils down to whether an informed party ("insiders") benefits more than other market participants ("outsiders") due to access to proprietary information and whether there is a potential to abuse it. Non-forensic backgrounds are simply the extent to which insiders and managers are able to accommodate investor preferences with their corporate decisions that "manipulate" the stock price. For this dissertation, public equity markets are the experimental setting in which there is information asymmetry. That the consequences of this are systemically relevant is amplified by the financial crises and its ongoing externalities.

I close this section with a quote from a pioneering researcher in corporate finance. According to Jay Ritter (2008) “[...] researchers have to consider whether an empirical pattern has an innocuous explanation, or whether it represents a situation in which a small group of financial market insiders is benefiting at the expense of the broader investing public." This also casts doubt on the notorious citation, which introduces this dissertation because it disregards transparency and fairness in financial markets. Unfortunately, any finding in this direction is highly politicized (see the Wall Street Journal article by Maremont and Craig, 2008). This public and economic interest can undermine the actual second-guessing of the results that academics are interested in. Upon completion of this dissertation, I hope to have contributed to the clarification and to understanding manipulation in financial markets. 


\section{Bibliography}

Aboody, D., and R. Kasznik (2000), "CEO stock option awards and the timing of corporate voluntary disclosures", Journal of Accounting and Economics, 29 (1). $73-100$.

Acharya, V., and Johnson, T. (2007). Insider Trading in Credit Derivatives. Journal of Financial Economics, 84 (1). 110-141.

Acharya, V.V, and Schnabl, T. (2009). How Banks Played the "Leverage Game". In: Acharya, V.V., and Richardson, M. (eds.). Restoring Financial Stability How to Repair a Failed System. (New York: Wiley Finance).

Acharya, V.V., and Richardson, M. (2009). Restoring Financial Stability - How to Repair a Failed System (eds.). (New York: Wiley Finance).

Admati, A.R., and Pfleiderer, P. (2009). The "Wall Street Walk" and Shareholder Activism: Exit as a Form of Voice. Review of Financial Studies, 22 (7). 2645-2685.

Aggarwal, R. (2000). Stabilization Activities by Underwriters After Initial Public Offers. The Journal of Finance, 55 (3). 1075-1103.

Aggarwal, R. (2003). Allocation of Initial Public Offerings and Flipping Activity. Journal of Financial Economics, 68 (1). 111-135.

Aggarwal, R., Prabhala, N.P., and Puri, M. (2002). Institutional Allocation in Initial Public Offerings: Empirical Evidence. The Journal of Finance, 57 (6). 1421-1442.

Aggarwal, R.K., and Wu, G. (2006). Stock Market Manipulations. Journal of Business, 79 (4). 1915-1953.

Aggarwal, R.K., Purnanandam, A.K., and Wu, G. (2006). Underwriter Manipulation of Initial Public Offerings. Unpublished Working Paper. 
Agrawal, A. K. (2008). Corporate Governance Objectives of Labor Union Shareholders: Evidence from Proxy Voting. Working Paper.

Agrawal, A., and Chadha, S. (2005). Corporate Governance and Accounting Scandals. Journal of Law and Economics, 48 (2). 371-406.

Aguilera, R.V., Rupp, D.E., Williams, C.A., \& Ganapathi, J. (2007). Putting the 'S' Back in Corporate Social Responsibility: A Multilevel Theory of Social Change in Organizations. Academy of Management Review, 32 (3). 836863.

Akerlof, G.A. (1970). The Market for "Lemons". Quality Uncertainty and the Market Mechanism. Quarterly Journal of Economics, 84 (3). 488-500.

Alexander, J. (1991). Do the Merits Matter? A Study of Settlements in Securities Class Actions. Stanford Law Review 43. 497-588.

Alexander, J. (1993). The Lawsuit Avoidance Theory of Why Initial Public Offerings are Underpriced. UCLA Law Review, 41. 17-73.

Allen, F., Faulhaber, G. (1989). Signaling by Underpricing in the IPO Market. Journal of Financial Economics, 23 (2). 303-323.

Almeida, H., and Philippon, T. (2007). The Risk-Adjusted Costs of Financial Distress. The Journal of Finance, 62 (6). 2557-2587.

Armour, J., Black, B., Cheffins, B., and Nolan, R. (2009). Private Enforcement of Corporate Law: A Comparative Empirical Analysis of the UK and the U.S.. Working paper available on SSRN: http://ssrn.com/abstract $=1105355$

Andrade, G., and Kaplan, S.N. (1998). How Costly is Financial (Not Economic) Distress? Evidence from Highly Levered Transactions that Became Distressed. The Journal of Finance, 53 (5). 1443-1493.

Ashraf, R., Jayaraman, N., \& Ryan Jr., H.E. (2009). Conflicts of Interest and Mutual Fund Proxy Voting: Evidence from Shareholder Proposals on Executive Compensation. Financial Management Association 2009 Working Paper.

Bainbridge, S. M. (2006). Director Primacy and Shareholder Disempowerment Response. Harvard Law Review, 119. 1735-1758

Baker, M., Coval, J., and Stein, J.C. (2007). Corporate Financing Decisions when Investors take the Path of Least Resistance. Journal of Financial Economics, 84 (2). 266-298. 
Bates, T.W., Becher, D.A, and Lemmon, M.L. (2008). Board Classification and Managerial Entrenchment. Evidence from the Market For Corporate Control. Journal of Financial Economics, 87 (3). 656-677.

Bauer, R., and Braun, R. (2010). Long-Term Performance of Distressed Firms: The Role of Class-Action Lawsuits. Working paper: http://papers.ssrn.com/abstract $=1577189$.

Bauer, R., Braun, R., and Clark, G.L. (2008). The Emerging Market for European Corporate Governance: the Relationship between Governance and Capital Expenditures, 1997-2005. Journal of Economic Geography, 8. 441-468.

Bauer, R., Braun, R., and Moers, F. (2009). Sued or Glued? How to Align the CEO? Maastricht University and ECCE Working Paper.

Bauer, R., Braun, R., and Viehs, M. (2010). Industry Competition, Ownership Structure and Shareholder Activism. Working Paper available on SSRN http://papers.ssrn.com/abstract $=1633536$.

Bauer, R., Guenster, N. and Otten, R. (2004). Empirical Evidence on Corporate Governance in Europe. The Effect on Stock Returns, Firm Value and Performance. Journal of Asset Management 5 (2). 91-104.

Beatty, R., Ritter, J., (1986). Investment Banking, Reputation, and the Underpricing of Initial Public Offerings. Journal of Financial Economics 15, (1/2). 213232.

Bebchuk, L. A., \& Cohen, A. (2005). The Costs of Entrenched Boards. Journal of Financial Economics, 78 (2). 409-433.

Bebchuk, L. A., Cohen, A., \& Ferrell, A. (2009). What Matters in Corporate Governance? The Review of Financial Studies, 22 (2). 783-827.

Bebchuk, L.A., and Fried. J. (2004). Pay Without Performance: The Unfulfilled Promise of Executive Compensation. Cambridge Massachusetts: Harvard University Press.

Bebchuk, L., Grinstein, Y., and Peyer, U. (2009). Lucky CEOs and Lucky Directors. Forthcoming in The Journal of Finance.

Becht, M., Bolton, P., and Röell, A. (2003). Corporate Governance and Control. In: Constantinides, G., Harris, A., and Stulz, R. (eds.). Handbook of The Economics of Finance - Volume 1A: Corporate Finance. (Amsterdam: North-Holland Publishers). 
Benveniste, L., Spindt, P. (1989). How Investment Bankers Determine the Offer Price and Allocation of New Issues. Journal of Financial Economics, 24 (2). 343-362.

Bergstresser, D., and Philippon, T. (2006). CEO Incentives and Earnings Management. Journal of Financial Economics, 80 (3). 511-529.

Bertrand, M., and Mullainathan, S. (2000). Agents With and Without Principals. American Economic Review, 90 (2). 203-208.

Bertrand, M. and Mullainathan, S. (2001). Are CEOs Rewarded For Luck? The Ones Without Principals Are. Quarterly Journal of Economics, 116 (3). 901-932.

Bertrand, M., and Mullainathan, S. (2003). Enjoying the Quiet Life? Corporate Governance and Managerial Preferences. Journal of Political Economy, 111 (5). 1043-1075.

Bharath, S.T., and Shumway, T. (2008). Forecasting Default with the Merton Distance to Default Model. Review of Financial Studies, 21 (3). 1339-1369.

Bodnaruk, A., Braun, R., and Massa, M. (2009). Laddered IPOs: A Case of Ineffective Regulation? Working paper.

Bodnaruk, A., Massa, M., and Simonov, A. (2009). Investment Banks as Insiders and the Market for Corporate Control. The Review of Financial Studies, 22 (12). 4989-5026.

Bodnaruk, A. and Östberg, P. (2009). The Shareholder Base and Payout Policy. AFA 2009 San Francisco Meetings Paper.

Bohn, J., and Choi, S. (1996). Fraud in the New-Issue Market: Empirical Evidence on Securities Class Actions. University of Pennsylvania Law Review, 144. 903-982.

Boot, A.W.A., Gopalan, R., and Thakor, A.V. (2008). Market Liquidity, Investor Participation, and Managerial Autonomy: Why Do Firms Go Private? The Journal of Finance, 63 (4). 2013-2059.

Bowen, R.M., Rajgopal, S., and Venkatachalam, M. (2008). Accounting Discretion, Corporate Governance, and Firm Performance. Contemporary Accounting Research, 25 (2). 351-405. 
Brav, A., Géczy. C., and Gompers, P.A. (2000). Is the Abnormal Return Following Equity Issuances Anomalous? Journal of Financial Economics, 56 (2). 209-249.

Brav A., and Gompers, P.A. (1997). Myth or Reality? The Long-Run Underperformance of Initial Public Offerings: Evidence from Venture and Nonventure Capital-Backed Companies. The Journal of Finance, 52 (5). 1791-1821.

Brav, A., Jiang, W., Partnoy, F., \& Thomas, R. (2008). Hedge Fund Activism, Corporate Governance, and Firm Performance. The Journal of Finance, 63 (4), 1729-1775.

Brenner, M., Sundaram, R.K., and Yermack, D. (2000). Altering the Terms of Executive Stock Options. Journal of Financial Economics, 57 (1). 103-128.

Brown, S.J., and Warner, J.B. (1980). Measuring Security Price Performance. Journal of Financial Economics, 8 (3). 205-258.

Burkart, M., Gromb, D., and Panunzi, F. (1997). Large Shareholders, Monitoring, and the Value of the Firm. Quarterly Journal of Economics, 112 (3). 693728.

Burkart, M. and Panunzi, F. (2008). Takeovers. In Freixas, X., Hartmann, P., and Mayer, C. (eds.). Handbook of European Financial Markets and Institutions. (Oxford: Oxford University Press).

Bushee, B.J. (1998). The Impact of Institutional Investors on Myopic R\&D Investment Behavior. The Accounting Review, 73 (3). 305-333.

Campbell, C. J., Gillan, S. L., \& Niden, C. M. (1999). Current Perspectives on Shareholder Proposals: Lessons from the 1997 Proxy Season. Financial Management, 28 (1). 89-98.

Campbell, J.Y., Lo, A.W, and MacKinlay, C. (1997). The Econometrics of Financial Markets. Princeton University Press.

Caprasse, J.N. (2005). Trends \& Ratings 2003. Corporate Governance Research and Ratings. Available on: http://www.deminor.org/

Carhart, M. (1997). On the Persistence of Mutual Fund Performance. The Journal of Finance, 52 (1). 57-82. 
Carleton, W.T., Nelson, J.M. \& Weisbach, M.S. (1998). The Influence of Institutions on Corporate Governance through Private Negotiations: Evidence from TIAA-CREF. The Journal of Finance, 53 (4). 1335-1362.

Carter, R., Manaster, S. (1990). Initial Public Offerings and Underwriter Reputation. Journal of Finance, 45 (4). 1045-1067.

Carter, R., Dark, F., Singh, A. (1998). Underwriter Reputation, Initial Returns, and the Long-Run Underperformance of IPO Stocks. The Journal of Finance 53 (1). 285-311.

Carter, M., Lynch, L.J., and Tuna, I. (2007). The Role of Accounting in the Design of CEO Equity Compensation. The Accounting Review, 82 (2). 327-357.

Cestone, G., and Cespa, G. (2007). Corporate Social Responsibility and Managerial Entrenchment. Journal of Economics and Management Strategy, 16 (3). 741-771.

Chhaochharia, V., and Grinstein, Y. (2007). Corporate Governance and Firm Value: The Impact of the 2002 Governance Rules. The Journal of Finance, 62 (4). 1789-1836.

Chen, X., Harford, J. \& Li, K. (2007). Monitoring: Which Institutions Matter? Journal of Financial Economics, 86 (2). 279-305.

Chidambaran, N. K., \& Woidtke, T. (1999). The Role of Negotiations in Corporate Governance: Evidence from Withdrawn Shareholder-Initiated Proposals. NYU Center for Law and Business Research Paper No. 99-12.

Choi, S. J. (2007). Do the Merits Matter Less After the Private Securities Litigation Reform Act? The Journal of Law, Economics \& Organization, 23 (3). 598626.

Choi, S. and Pritchard, A.C. (2004). Should Issuers be on the Hook for Laddering? An Empirical Analysis of the IPO Market Manipulation Litigation. The John M. Olin Center for Law \& Economics Working Paper Series

Cicero, D. C. (2009). The Manipulation of Executive Stock Option Exercise Strategies: Information Timing and Backdating. The Journal of Finance, 64 (6). 2627-2664.

Clark, G.L. Wójcik, D., and Bauer, R. (2006). Geographically Dispersed Ownership and Inter-Market Stock Price Arbitrage - Ahold's Crisis of Corporate 
Governance and its Implications for Global Standards. Journal of Economic Geography 6. 303-22.

Clark, G.L, and Wójcik, D. (2007). The Geography of Finance. Oxford: Oxford University Press.

Cochrane, J. H. (2005). Asset Pricing (revised ed.). New Jersey: Princeton University Press.

Coffee, J.C. (2002). Racing Towards the Top? The Impact of Cross-Listing and Stock Market Competition on International Corporate Governance. Columbia Law Review, 102. 1757-131.

Collins, D.W., Maydew, E.L., and Weiss, I.S. (1997). Changes in the Value Relevance of Book Values over the Past Forty Years. Journal of Accounting and Economics 24, (1). 39-67.

Coffee, J.C. (2005). A Theory of Corporate Scandals: Why the USA and Europe Differ. Oxford Review of Economic Policy, 21 (2). 198-211.

Comment, R., and Schwert, W.B. (1995). Poison or Placebo? Evidence on Deterrence and Wealth Effects of Modern Anti-Takeover Measures. Journal of Financial Economics, 39. 3-43.

Core, J.E. (1997). On the Corporate Demand for Directors' and Officers' Insurance. Journal of Risk and Insurance, 64 (1). 63-87.

Core, J.E. (2000). The Directors' and Officers' Insurance Premium: An Outside Assessment of the Quality of Corporate Governance. Journal of Law, Economics, and Organization, 16 (2). 449-477.

Core, J.E., and Guay, W.R. (1999). The Use of Equity Grants to Manage Optimal Incentive Levels. Journal of Accounting and Economics, 28 (2). 151-184.

Core, J.E., and Guay, W.R. (2002). Estimating the Value of Employee Stock Option Portfolios and Their Sensitivity to Price and Volatility. Journal of Accounting Research, 40 (3). 613-630.

Core, J.E., Guay, W.R., and Verrecchia, R.E. (2003). Price versus Non-Price Performance Measures in Optimal CEO Compensation Contracts. The Accounting Review, 78 (4). 957-981. 
Core, J.E., Holthausen, R.W., and Larcker, D.F. (1999). Corporate Governance, Chief Executive Officer Compensation and Firm Performance. Journal of Financial Economics, 51 (3). 371-406.

Core, J.E., and Larcker, D.F. (2002). Performance Consequences of Mandatory Increases in Executive Stock Ownership. Journal of Financial Economics, 64 (3). 317-340.

Cornett, M.M., Marcus, A.J., Saunders, A., \& Tehranian, H. (2007). The Impact of Institutional Ownership on Corporate Operating Performance. Journal of Banking and Finance, 31 (6). 1771-1794.

Cosemans, M., Frehen, R., Schotman, P.C., and Bauer, R. (2009). Efficient Estimation of Firm-Specific Betas and its Benefits for Asset Pricing Tests and Portfolio Choice. Working Paper available online: http://ssrn.com/abstract $=1342326$

Cremers, K.J.M., Nair, V.B., and Wei, C. (2007). Governance Mechanism and Bond Prices. Review of Financial Studies, 20 (5). 1359-1388.

Cunningham, L. A. (1999). Commonalities and Prescriptions in the Vertical Dimension of Global Corporate Governance. Cornell Law Review 84. 1133.

Daines, R. (2001). Does Delaware Law Improve Firm Value? Journal of Financial Economics, 62 (3). 525-558.

Daines, R., and Klausner, M. (2001). Do IPO Charters Maximize Firm Value? Antitakeover Protection in IPOs. Journal of Law, Economics \& Organization 17 (1). 83-120.

Damodaran, A. (2002). Investment Valuation. New York: Wiley \& Sons.

Damodaran, A., and Liu, C.H. (1993). Insider Trading as a Signal of Private Information. Review of Financial Studies, 6 (1). 79-119.

Daniel, K., Grinblatt, M., Titman, S., \& Wermers, R. (1997). Measuring Mutual Fund Performance with Characteristic-Based Benchmarks. The Journal of Finance, 52 (3). 1035-1059.

Davis, G. F., \& Kim, E. H. (2007). Business Ties and Proxy Voting by Mutual Funds. Journal of Financial Economics, 85 (2). 552-570. 
DeAngelo, H. \& DeAngelo, L. (1985). Managerial Ownership of Voting Rights. A Study of Public Corporations with Dual Classes of Common Stock. Journal of Financial Economics, 14 (1). 33-69.

Dechow, P., Sloan, R.G., and Sweeney, A.P. (1996). Causes and Consequences of Earnings Manipulation: An Analysis of Firms Becoming Subject to Enforcement Actions by the SEC. Contemporary Accounting Research, 36 (1). 1-36.

Del Guercio, D., \& Hawkins, J. (1999). The motivation and impact of pension fund activism. Journal of Financial Economics, 52 (3). 293-340.

Demsetz, H. \& Lehn, K. (1985). The Structure of Corporate Ownership: Causes and Consequences. Journal of Political Economy, 93(6), 1155-1177.

Demsetz, H. \& Villalonga, B. (2001). Ownership structure and corporate performance. Journal of Corporate Finance, 7, 209-233.

Doidge, C., Karolyi, A.G., and Stulz, R.M. (2009). Has New York Become Less Competitive than London in Global Markets? Evaluating Foreign Listing Choices over Time. Journal of Financial Economics, 91 (3). 253-277.

Jong, A. de, DeJong, D., Mertens, G.M.H., \& Roosenboom, P.G.J. (2009). Royal Ahold: The Role of Corporate Governance. In G. Aras \& D. Crowther (Eds.), The Gower Handbook of Corporate Governance and Social Responsibility.

Dittmar, A. and Mahrt-Smith, J. (2007). Corporate Governance and the Value of Cash Holdings. Journal of Financial Economics, 83 (3). 599-634.

Dore, R. (2000). Stock Market Capitalism: Welfare Capitalism. Oxford and New York: Oxford University Press.

Drake, P., and Vetsuypens, M. (1993). IPO Underpricing and Insurance against Legal Liability. Financial Management, 22 (1). 64-73.

DuCharme, L.L., Malatesta, P.H., and Sefcik, S.E. (2004). Earnings Management, Stock Issues, and Shareholder Lawsuits. Journal of Financial Economics, 71 (1). 27-49.

Durnev, A., and Kim, E.H. (2005). To Steal or Not to Steal: Firm Attributes, Legal Environment, and Valuation. The Journal of Finance, 60 (3). 1461-1494. 
Eckbo, E.B., Masulis, R.W., and Norli, Ø. (2000). Seasoned Public Offerings: Resolution of the "New Issues Puzzle". Journal of Financial Economics, 56 (2). 251-291.

Eckbo, B.E. and Norli, Ø. (2005), Liquidity Risk, Leverage and Long-Run IPO Returns. Journal of Corporate Finance, 11 (1/2). 1-35.

Edmans, E. (2009). Blockholder Trading, Market Efficiency, and Managerial Myopia. The Journal of Finance, 64 (6). 2481-2513.

Edmans, A., Gabaix, X. \& Landier, A. (2009). A Multiplicative Model of Optimal CEO Incentives in Market Equilibrium. The Review of Financial Studies, 22(12), 4881-4917.

Edmans, A., \& Manso, G. (2010). Governance Through Exit and Voice: A Theory of Multiple Blockholders. AFA 2009 San Francisco Meetings Paper.

Ellis, K., Michaely, R., and O'Hara, M. (2000) When the Underwriter is the Market Maker: an Examination of Trading in the IPO Aftermarket. The Journal of Finance, 55 (3).1039-1074.

European Corporate Governance Institute. (2006). Codes and Principles, Research and Publications. www.ecgi.org

Faleye, O. (2007). Classified Boards, Firm Value and Managerial Entrenchment. Journal of Financial Economics, 83 (2). 501-529.

Fama, E. (1998). Market Efficiency, Long-Term Returns, and Behavioral Finance. Journal of Financial Economics, 49 (3). 283-306.

Fama, E.F., and MacBeth, J. (1973). Risk, Return and Equilibrium: Empirical Tests. Journal of Political Economy, 81 (3). 607-636

Fich, E.M., and Shivdasani, A. (2007). Financial Fraud, Director Reputation, and Shareholder Wealth. Journal of Financial Economics, 86 (2). 306-336.

Gabaix, X., and Landier, A. (2008). Why Has CEO Pay Increased so Much?. Quarterly Journal of Economics, 123 (1). 49-100.

Gabaix, X., and Edmans, A. (2009). Is CEO Pay Really Inefficient? A Survey of New Optimal Contracting Theories. European Financial Management, 15 (3). 486-496.

Gaspar, J.-M. \& Massa, M. (2006). Idiosyncratic Volatility and Product Market Competition. Journal of Business, 79 (6), 3125-3152. 
Géczy, C.C., Minton, B.A., and Schrand, C.M. (2007). Taking a View: Corporate Speculation, Governance, and Compensation. Journal of Finance, 62 (5). 2405-2443.

Gertler, M.S. (2001). Best Practice? Geography, Learning and the Institutional Limits to Strong Convergence. Journal of Economic Geography 1. 5-26

Giannetti, M., and Simonov, A. (2006). Which Investors Fear Expropriation? Evidence from Investors' Portfolio Choices. The Journal of Finance, 61 (3). 1507-1547.

Gillan, S. L., \& Starks, L. T. (2000). Corporate Governance Proposals and Shareholder Activism: the Role of Institutional Investors. Journal of Financial Economics, 57 (2). 275-305.

Gillan, S. L. \& Starks, L.T. (2007). The Evolution of Shareholder Activism in the United States. Journal of Applied Corporate Finance, 19 (1). 55-73.

Giroud, X., \& Mueller, H. M. (2009). Corporate Governance, Product Market Competition and Equity Prices. Forthcoming in The Journal of Finance.

Giroud, X., \& Mueller, H. M. (2010). Does Corporate Governance Matter in Competitive Industries? Journal of Financial Economics, 95 (3). 312-331.

Gompers, P. A., Ishii, J. L. and Metrick, A. (2003). Corporate Governance and Equity Prices. Quarterly Journal of Economics, 118 (1). 107-155.

Gompers, P., Ishii, J. \& Metrick, A. (2009). Extreme Governance: An Analysis of Dual-Class Firms in the United States. Review of Financial Studies forthcoming.

Gompers, P., and J. Lerner. (1998). Venture Capital Distributions: Short-Run and Long-Run Reactions. The Journal of Finance, 53 (6). 2161-2183.

Gordon, L. A., \& Pound, J. (1993). Information, Ownership Structure, and Shareholder Voting: Evidence from Shareholder-Sponsored Corporate Governance Proposals. Journal of Finance, 48 (2). 697-718.

Gordon, J. N. and Roe, M. J. (Eds.) (2004). Convergence and Persistence in Corporate Governance. Cambridge: Cambridge University Press.

Greenwood, R., and Thesmar, D. (2010). Stock Price Fragility. Working Paper: http://papers.ssrn.com/sol3/papers.cfm?abstract_id $=1490734$. 
Griffin, J.M., Harris, J.H., and Topaloglu, S. (2007). Why are IPO Investors Net Buyers through Lead Underwriters? Journal of Financial Economics, 85 (2). 518-551.

Grinblatt, M., Hwang, C. (1989). Signaling and the Pricing of New Issues. The Journal of Finance, 44 (2). 393-420.

Grinstein, Y., and Hribar, P. (2004). CEO Compensation and Incentives: Evidence from M\&A Bonuses. Journal of Financial Economics, 73 (1). 119-143.

Grullon, G., Kanatas, G., \& Weston, J.P. (2004). Advertising, Breadth of Ownership, and Liquidity. The Review of Financial Studies, 17 (2). 439461.

Hall, B. J. (2003). Six Challenges in Designing Equity-Based Pay. Accenture Journal of Applied Corporate Finance, 15 (3). 21.

Hall, B.J., and Liebman, J.B. (1998). Are CEOs Really Paid Like Bureaucrats? Quarterly Journal of Economics, 113 (3). 653-691.

Hanley, K. (1993). The Underpricing of Initial Public Offerings and the Partial Adjustment Phenomenon. Journal of Financial Economics, 34 (2). 231250 .

Hanley, K.W., and Wilhelm, W. (1995) Evidence on the Strategic Allocation of Initial Public Offerings. Journal of Financial Economics 37 (2). 239-257.

Hao, Q. (2007). Laddering in Initial Public Offerings. Journal of Financial Economics, 85 (2). 102-122.

Hart, O.D. (1983). The Market Mechanism as an Incentive Scheme. The Bell Journal of Economics, 14 (2). 366-382.

Hart, O. (1995). Firms, Contracts, and Financial Structure. (London: Oxford University Press)

Hebb, T. (2006). The Economic Inefficiency of Secrecy: Pension Fund Investors' Corporate Transparency Concerns. Journal of Business Ethics, 63 (4). 385 405.

Hermalin, B.E., and Weisbach, S.E. (1988). The Determinants of Board Composition. RAND Journal of Economics, 19 (4). 589-606. 
Hermalin, B.E., and Weisbach, S.E. (1998). Endogeneously Chosen Boards and Their Monitoring Role of the CEO. American Economic Review 88 (1). 96118.

Hermalin, B.E., and Weisbach, M.S. (2003). Boards of Directors as an Endogenously Determined Institution: A Survey of the Economic Literature. FRBNY Economic Policy Review, 9 (1). 6-26.

Heron, R.A., and Lie, E. (2009). What Fraction of Stock Option Grants to Top Executives Have Been Backdated or Manipulated?. Management Science, 55 (4). 513-525.

Hillion, P., and Vermaelen, T. (2004). Death Spiral Convertibles. Journal of Financial Economics, 71 (2). 381-416.

Hopt, K. J., Kanda, H., Roe, M. J., Wymeersch, E. and Prigge, S. Eds. (1998). Comparative Corporate Governance: The State of the Art and Emerging Research. Oxford: Oxford University Press.

Hughes, P., Thakor, A. (1992). Litigation Risk, Intermediation, and the Underpricing of Initial Public Offerings. Review of Financial Studies, 5 (4), 709-742.

Ibbotson, R., (1975). Price Performance of Common Stock New Issues. Journal of Financial Economics, 2 (3). 235-272.

Ibbotson, R., Sindelar, J., Ritter, J., 1988. Initial public offerings. Journal of Applied Corporate Finance, 1.37-45.

Ibbotson, R., Sindelar, J., Ritter, J., 1994. The Market's Problems with the Pricing of Initial Public Offerings. Journal of Applied Corporate Finance 7. 66-74.

Ivashina, V. and Sun, Z, (2010). Institutional Stock Trading on Loan Market Information. Forthcoming in the Journal of Financial Economics.

Jegadeesh, N., Weinstein, M., Welch, I., (1993). An Empirical Investigation of IPO Returns and Subsequent Equity Offerings. Journal of Financial Economics, 34 (2). 153-175.

Jenkinson, T., Jones, H. (2009). IPO pricing and allocation: a survey of the views of institutional investors. Review of Financial Studies, 22 (4). 1477-1504

Jensen, M. C. (1986). Agency Costs of Free Cash Flow, Corporate Finance, and Takeovers. AEA Papers and Proceedings, 76 (2), 323-329. 
Jensen, M.C. (2000). A Theory of the Firm. Cambridge MA: Harvard University Press.

Jensen, M.C., and Meckling, W.H. (1976). Theory of the Firm - Managerial Behavior, Agency Costs and Ownership Structure. Journal of Financial Economics, 3 (4). 305-360.

Jensen, M.C., and Murphy, K. (1990). Performance Pay and Top Management Incentives. Journal of Political Economy, 98 (2). 225-264.

John, K., \& Kadyrzhanova, D. (2008). Relative Governance. Working Paper.

John, K., \& Kedia, S. (2006). Institutions, Markets and Growth: A Theory of Comparative Corporate Governance. Working Paper.

John, K., \& Litov, L. (2009). Corporate Governance and Financing Policy: New Evidence. Working Paper.

Jones, C., Weingram, S. (1996). Why 10b-5 Risk is Higher for Technology and Financial Service Firms. Unpublished Working Paper Stanford Law School.

Johnson, M.F., Nelson, K.K., and Pritchard, A.C. (2007). Do the Merits Matter More? The Impact of the Private Securities Litigation Reform Act. The Journal of Law, Economics \& Organization, 23 (3). 627-652.

Kahn, C. \& Winton, A. (1998). Ownership Structure, Speculation, and Shareholder Intervention. The Journal of Finance, 53 (1). 99-129.

Kandel, E., Leshchinskii, D., and Yuklea, H. (2010). VC Funds: Aging Brings Myopia. Forthcoming in the Journal of Financial and Quantitative Analysis.

Karpoff, J.M., Lee, D.S., and Martin, G.S. (2008a). The Consequences to Managers for Financial Misrepresentation. Journal of Financial Economics, 88 (2). 193-215.

Karpoff, J.M., Lee, D.S., and Martin, G.S. (2008b). The Cost to Firms for Cooking the Books. Journal of Financial and Quantitative Analysis, 43 (3). 581612.

Karpoff, J. M., Malatesta, P. H., \& A.Walkling, R. (1996). Corporate governance and shareholder initiatives: Empirical evidence. Journal of Financial Economics, 42 (3). 365-395. 
Karuna, C. (2007). Industry product market competition and managerial incentives. Journal of Accounting and Economics, 43 (2/3). 275-297.

Karuna, C. (2008). Industry Product Market Competition and Corporate Governance. Working Paper.

Kato, H.K., Lemmon, M., Luo, M., and Schallheim, J. (2005). An Empirical Examination of the Costs and Benefits of Executive Stock Options: Evidence from Japan. Journal of Financial Economics, 78 (2). 435-468.

Kedia, S., and Philippon, T. (2009). The Economics of Fraudulent Accounting. The Review of Financial Studies, 22 (6). 2169-2199.

Keloharju, M. (1993). The Winner's Curse, Legal Liability, and the Long-Run Price Performance of Initial Public Offerings in Finland. Journal of Financial Economics, 34 (2). 251-277.

Klapper, L.F., and Love, I. (2004). Corporate Governance, Investor Protection, and Performance in Emerging Markets. Journal of Corporate Finance, 10 (5). 703-728.

Kothari, S.P, and Warner, J.B. (2007). Econometrics of Event Studies. In Eckbo, B. E. (ed.). Handbook of Corporate Finance. Volume 1: Empirical Corporate Finance. (Amsterdam: North-Holland Publishers).

Krishnan, J., and Krishnan, J. (1997). Litigation Risk and Auditor Resignations. The Accounting Review, 72 (4). 539-560.

Lang, L.H.P., and John, K. (1991). Insider Trading Around Dividend Announcements - Theory and Evidence. The Journal of Finance, 46 (4). 1361-1389

La Porta, R., Lopez-de-Silanes, F., Shleifer, A., and Vishny, R. (1998). Law and Finance. Journal of Political Economy, 106 (6). 1113-1155.

La Porta, R., Lopez-de-Silanes, F., Shleifer, A., and Vishny, R. (2002). Investor Protection and Corporate Valuation. The Journal of Finance, 57 (3). 11471170.

Larcker, D.F., Richardson, S.A., and Tuna, I. (2007). Corporate Governance, Accounting Outcomes, and Organizational Performance. The Accounting Review, 82 (5). 963-1008. 
Leland, H., Pyle, D. (1977). Information Asymmetries, Financial Structure and Financial Intermediation. The Journal of Finance, 32 (2). 371-387.

Lin, T., and R. L. Smith. (1998). The Unwinding of Venture Capital Investments: Insider Selling During Equity IPOs. Journal of Corporate Finance (4). 241-263.

Loss, L., and Seligman, J. (2004). Fundamentals of Securities Regulation (5 $5^{\text {th }}$ ed.). Aspen Publishers.

Loughran, T., Ritter, J. (2002). Why Don't Issuers Get Upset About Leaving Money on the Table in IPOs? Review of Financial Studies, 15 (2). 413-444.

Loughran, T., Ritter, J.R. (2004). Why has IPO Underpricing Changed over Time? Financial Management, 33 (3). 5-37.

Loughran, T., J. R. Ritter, and K. Rydqvist. (1994) Initial Public Offerings: International Insights. Pacific-Basin Finance Journal, 2. 165-199.

Loughran, T. and J. R. Ritter. (1995) The New Issues Puzzle. The Journal of Finance, 50 (1). 23-51.

Lowry, M., and Schwert, G.W. (2004). Is the IPO Pricing Process Efficient? Journal of Financial Economics, 71 (1). 3-27.

Lowry, M., and Shu, S. (2002). Litigation Risk and IPO Underpricing. Journal of Financial Economics, 65 (3). 309-335.

Massoud, N., Nandy, D, Saunders, A., and Song, K. (2009). Do Hedge Funds Trade on Private Information? Evidence from Syndicated Lending and ShortSelling. Working paper available at: http://ssrn.com/abstract $=1462561$

Maddala, G., 1983. Limited-Dependent and Qualitative Variables in Econometrics. Cambridge University Press, Cambridge, England.

Maremont, M., and Craig, S. Trading in Deal Stocks Triggers Looks at Banks. Wall Street Journal Print Edition, January 14, 2008.

Massa, M. and Rehman, Z. (2008). Information Flows within Financial Conglomerates: Evidence from the Banks-Mutual Funds Relationship. Journal of Financial Economics, 89 (2). 288-306.

Maug, E. (1998). Large Shareholders as Monitors: Is There a Trade-Off between Liquidity and Control? The Journal of Finance, 53 (1), 65-98. 
McCahery, J. A., Moerland, P., Raaijmakers, T., and Renneboog, T. Eds. (2002). Corporate Governance Regimes: Convergence and Diversity. Oxford: Oxford University Press

Megginson, W., Weiss, K. (1991). Venture Capitalist Certification in Initial Public Offerings. The Journal of Finance, 46 (3). 879-904.

Merton, R.C. (1987). A Simple Model of Capital Market Equilibrium with Imperfect Information. The Journal of Finance, 42 (3). 483-510

Michaely, R., Shaw, W. (1994). The Pricing of Initial Public Offerings: Tests of Adverse-Selection and Signaling Theories. Review of Financial Studies, 7 (2). 279-319.

Miller, M. (1977). Debt and Taxes. The Journal of Finance, 32 (2). 261-277.

Miller, M., \& Modigliani, F. (1958). The Cost of Capital, Corporation Finance, and the Theory of Investment. American Economic Review, 48 (3). 261-298.

Miller, M.H., and Rock, K. (1985). Dividend Policy under Asymmetric Information. The Journal of Finance, 40 (4). 1031-1052.

Mitchell, M.L., and Stafford, E. (2000). Managerial Decisions and Long-Term Stock Price Performance. Journal of Business, 73 (3). 287-330.

Monk A.H.B. (2008). American and Japanese Corporate Pensions: Convergence or Path Dependence in the Era of Globalization? Working Paper available at SSRN: http://ssrn.com/abstract $=1082887$

Monks, R.A.G., and Minow, N. Eds. (2004). Corporate Governance (3rd ed.). Malden, USA: Blackwell Publishing

Morck, R., Shleifer, A. \& Vishny, R.W. (1988). Management ownership and market valuation. An Empirical Analysis. Journal of Financial Economics, 20 (1/2). 293-315.

Mulherin, H.J., and Poulsen, A.B. (1998). Proxy Contests and Corporate Change: Implications for Shareholder Wealth, Journal of Financial Economics, 47 (3). $279-313$.

Myers, S., and Majluf, N. (1984). Corporate Financing and Investment Decisions when Firms have Information that Investors Do Not Have. Journal of Financial Economics, 13 (2). 187-221. 
Ofek, E., and Yermack, D. (2000). Taking Stock: Equity-Based Compensation and The Evolution of Managerial Ownership. The Journal of Finance, 55 (3). 1367-1384.

Pagano, M., Panetta, F., and Zingales, L. (1998). Why do Companies Go Public? An Empirical Analysis. The Journal of Finance, 53 (1). 27-64.

Pagano, M., and Volpin, P.F. (2005). Managers, Workers, and Corporate Control. The Journal of Finance, 60 (2). 841-869.

Parrino, R., Sias, R.W., \& Starks, L. (2003). Voting With Their Feet: Institutional Ownership Changes Around Forced CEO Turnover. Journal of Financial Economics, 68 (1). 3-46.

Peck, J. and Theodore, N. (2007). Variegated Capitalisms. Progress in Human Geography, 31 (6). 731-772.

Peng, L. and Röell, A. (2008a). Executive Pay and Shareholder Litigation. Review of Finance, 12 (1). 141-184.

Peng, L. and Röell, A. (2008b). Manipulation and Equity-Based Compensation. American Economic Review Papers \& Proceedings, 98 (2). 285-290.

Pound, J. (1988). Proxy Contests and the Efficiency of Shareholder Oversight. Journal of Financial Economics, 20 (1/2). 237-265.

Povel, P., Singh, R., and Winton, A. (2007). Booms, Busts and Fraud. Review of Financial Studies, 20 (4). 1219-1254.

Rauh, J.D., and Sufi, A. (2009). Capital Structure and Debt Structure. Forthcoming in the Review of Financial Studies.

Renders, A. and Gaeremynck, A. (2006). Corporate Governance and Performance Controlling for Sample Selection Bias and Endogeneity. K.U. Leuven AFI Working Paper No. 0606

Richardson, M., and White, L. (2009). The Rating Agencies. In: Acharya, V.V., and Richardson, M. (eds.). Restoring Financial Stability - How to Repair a Failed System. (New York: Wiley Finance).

Ritter, J.R. (1984). The Hot Issue Market of 1980. Journal of Business, 57 (2). 215240.

Ritter, J.R. (2008). Forensic Finance. Journal of Economic Perspectives, 22 (3). 127-147. 
Ritter, J.R., and Welch, I. (2002). A Review of IPO Activity, Pricing, and Allocations. The Journal of Finance, 57 (4). 1795-1830.

Ritter, J.R. and Zhang, D. (2007). Affiliated Mutual Funds and the Allocation of Initial Public Offerings. Journal of Financial Economics, 86 (2). 337-368.

Rock, K. (1986). Why New Issues are Underpriced. Journal of Financial Economics, 15 (1/2). 187-212.

Roe, M.J. (2006). Legal Origins, Politics, and Modern Stock Markets. Harvard Law Review 120. 460-527.

Romano, R. (1991). The Shareholder Suit: Litigation Without Foundation?. Journal of Law, Economics \& Organization 7 (1). 55-87.

Ruud, J. (1993). Underwriter Price Support and the IPO Underpricing Puzzle. Journal of Financial Economics, 34 (2). 135-151.

Senbet, L.W., and Seward, J.K. (1995). Financial Distress, Bankruptcy and Reorganization. In: Jarrow, R.A., Maksimovic, V., and Ziemba, W.T. (eds.). Handbook in Operations Research and Management Science Volume 9: Finance. (Amsterdam: North-Holland Publishers).

Shin, H., and Kim, Y.H. (2002). Agency Costs and Efficiency of Business Capital Investment: Evidence from Quarterly Capital Expenditures. Journal of Corporate Finance, 8 (2). 139-158

Shivdasani, A., and Yermack, D. (1999). CEO Involvement in the Selection of New Board Members: An Empirical Analysis. The Journal of Finance, 54 (5). 1829-1853.

Shleifer, A., \& Vishny, R.W. (1986). Large Shareholders and Corporate Control. Journal of Political Economy, 94 (3). 461-488.

Shleifer, A. and Vishny, R. W. (1997). A Survey on Corporate Governance. The Journal of Finance, 52 (2). 737-783.

Shu, S. (2000). Auditor Resignations: Clientele Effects and Legal Liability. Journal of Accounting and Economics, 29 (2). 173-205.

Smith, M. P. (1996). Shareholder Activism by Institutional Investors: Evidence from CalPERS. The Journal of Finance, 11 (1). 227-252.

Sonnenfeld, J. (2004). Good Governance and the Misleading Myths of Bad Metrics. Academy of Management Executive, 18. 108-113 
Spence, M. (1973). Job Market Signaling. Quarterly Journal of Economics, 87 (3). 355-374.

Stein, J. (1988). Takeover Threats and Managerial Myopia. Journal of Political Economy, 96 (1). 61-80.

Stulz, R.M. (1988). Managerial Control of Voting Rights: Financing Policies and The Market for Corporate Control. Journal of Financial Economics, 20 (1/2). 25-54.

Sundaram, R.K., and Yermack, D. (2007). Pay Me Later: Inside Debt and Its Role in Managerial Compensation. The Journal of Finance, 62 (4). 1551-1588.

The Economist. “The crime in subprime”. Print edition. 19 December 2007.

The Economist. “Dates from hell”. Print edition. 20 July 2006.

The Economist. “The crime in subprime”. Print edition. 19 December 2007.

The Economist. Europe's Enron. Print edition. 27 February 2003

The Economist. Battling for Corporate America. Print edition. 11 March 2006

Tinic, S. (1988). Anatomy of Initial Public Offerings of Common Stock. The Journal of Finance, 43 (4). 789-822.

Tirole, J. (2001). Corporate Governance. Econometrica 69 (1). 1-35.

Titman, S., Wei, J.K.C., and Xie, F. (2004). Capital Investments and Stock Returns. Journal of Financial and Quantitative Analysis 39 (4). 677-700

Wahal, S. (1996). Pension Fund Activism and Firm Performance. Journal of Financial and Quantitative Analysis, 31 (1). 1-23.

Warner, J. (1977). Bankruptcy Costs: Some Evidence. The Journal of Finance 32 (2). 337-347.

Welch, I. (1989). Seasoned Offerings, Imitation Costs, and the Underpricing of Initial Public Offerings. The Journal of Finance, 44 (2). 421-450.

Welch, I. (1992). Sequential Sales, Learning and Cascades. The Journal of Finance, 47 (2). 695-732. 
Weston, F.J., Siu, J.A., and Johnson, B.A. Eds. (2001). Takeovers, Restructuring and Corporate Governance. $3^{\text {rd }}$ ed. Englewood Cliffs: New Jersey, USA: Prentice-Hall.

White, H. (1980). A Heteroskedasticity-Consistent Covariance Matrix Estimator and a Direct Test for Heteroskedasticity. Econometrica, 48. 817-838.

Wilhelm, W.J. and Downing, J.D. (2001). Information Markets: What Business Can Learn From Financial Innovation. Boston: Harvard Business School Press.

Wójcik, D. (2006). Convergence in Corporate Governance: Evidence from Europe and the Challenge for Economic Geography. Journal of Economic Geography, 6. 639-660.

Wójcik, D., Clark, G. and Bauer, R. (2005). Corporate Governance and CrossListing: Evidence from European Companies. Working paper, Oxford University and Maastricht University.

Wrigley, N., and Currah, A. (2003). The Stresses of Retail Internationalization: Lessons from Royal Ahold's Experience in Latin America. International Review of Retail, Distribution and Consumer Research 13. 221-243.

Yermack, D. (1997). Good timing: CEO Stock Option Awards and Company News Announcements. The Journal of Finance, 52 (2). 449-476.

Yermack, D. (2004). Remuneration, Retention and Reputation Incentives for Outside Directors. The Journal of Finance, 59 (5). 2281-2308.

Yermack, D. (2006a). Flights of Fancy: Corporate Jets, CEO Perquisites and Inferior Shareholder Returns. Journal of Financial Economics, 80 (1). 211-242.

Yermack, D. (2006b). Golden Handshakes: Separation Pay for Retired and Dismissed CEOs. Journal of Accounting and Economics, 41 (3). 237-256.

Yermack, D. (2009). Deductio Ad Absurdum: CEOs Donating Their Own Stock to Their Own Family Foundations. Journal of Financial Economics, 94. 107123.

Zhang, D. (2004). Why do IPO Underwriters Allocate Extra Shares when They Expect to Buy Them Back? Journal of Financial and Quantitative Analysis, 39 (3). 571-594.

Zingales, L. (1995). What Determines the Value of Corporate Votes? Quarterly Journal of Economics, 110 (4). 1047-1073. 


\section{Deutsche Zusammenfassung}

Die vorliegende Dissertation ermöglicht neue Einsichten in Bezug auf Situationen, in denen Marktteilnehmer internationale Wertpapiermärkte für Aktiengesellschaften vor dem Hintergrund von ungleicher Informationslage verwenden und eventuell ausnutzen. Weite Teile dieser Arbeit wurden durch die Literatur über Manager als Handelsbevollmächtigter der Aktionäre (der Eigentümer der Firma) und deren Interessenkonflikt inspiriert. Um sicher zu stellen, dass Manager im Interesse der Aktionäre handeln, gibt es das Konzept der verantwortungsvollen Unternehmensführung: kurz „Corporate Governance“. Ein weiterer Konflikt findet zwischen Firmen und Finanzinstituten statt; wie zum Beispiel Investment Banken. In Bezug auf ersteren Interessenkonflikt gibt es sowohl empirische als auch theoretisch-analytische Studien in reicher Zahl. Allerdings ist die akademische und politische Meinung über diesen Sachverhalt gespalten. Gibt das Verhältnis zwischen Aktionären (den eigentlichen Eigentümer eines Konzerns) und den Managern Anlass und Möglichkeit, Informationsvorteile auszunutzen oder stellt diese Situation bereits das optimale Vertragsverhältnis dar? Ein besonders politisiertes Thema, über das Uneinigkeit herrscht, findet sich insbesondere in der Frage der Vorstandsvergütung. Wohingegen berühmte und vielzitierte Werke von Bebchuk und Fried (2004), und die meisten Beiträge David Yermacks exzessive Vergütungen kritisieren und deren negative Auswirkungen auf die Firmenleistung und Profitabilität feststellen, findet ein weiteres akademisches Lager weniger eindeutige Antworten. Seit den Werken von Gabaix und Landier (2008), Edmans, Gabaix, und Landier (2009) sowie Edmans und Gabaix (2009) wurde die Diskussion über die Rechtmäßigkeit hoher Gehälter neu entfacht. Kurz zusammengefasst könnte zum Beispiel der Anstieg der Vorstandsvergütung ganz einfach eine Funktion von wachsender Firmengröße, größerem Wettbewerb um Managertalent oder einen allgemeinen Anstieg der Leistungsfähigkeit des Human Capital auf Marktebene sein. Als Konsequenz dessen habe sich die Vergütung des Chief Executive Officer (CEO) in den USA seit 1980 nicht etwa versechsfacht, weil der repräsentative Manager sechs Mal so gierig sei, sondern weil die Firma, die er leitet, einfach sechs Mal so groß und sechs Mal so wertvoll und profitabel sei. 
Damit Manager überhaupt in den Vorzug dieser Vergütung kommen, müssen sie mit gewissen Regeln im Markt konform gehen und Wert für die Aktionäre schaffen. Im internationalen Kontext müssen hierbei auch noch weitere Parteien (sogenannte ,stakeholder") mit einbezogen werden. Diese Dissertation liefert weitere wichtige Antworten auf die Fragen 1) wie Aktionäre im internationalen Kontext sicherstellen können, dass Manager in beidseitigem Interesse handeln, 2) welche Rolle dabei institutionelle Anleger spielen und 3) die möglichen Konsequenzen einer Verletzung der Manager-Pflichten.

In Bezug auf den zweiten angesprochenen Interessenkonflikt (zwischen Firmen und Finanzinstituten) findet sich ein Forschungsbereich, der in der letzten Zeit stark ansteigenden Zuspruch gewinnt. Dieser befasst sich mit koordiniertem Verhalten von Finanzkonglomeraten in Finanzmärkten. Akademische Forschungsbeiträge im Bereich der forensischen Finanzwissenschaften von Ritter (2008), Bodnaruk, Massa, und Simonov (2009) aber auch Bodnaruk, Braun, und Massa (2009) aus meiner vorliegenden Forschungsarbeit werden exemplarisch verstärkt durch die Vorfälle der aktuellen globalen Finanzkrise. Die Möglichkeit des Ausnutzens von Lücken in der Gesetzgebung (im Fachjargon: „regulatory arbitrage") von Seiten der Finanzinstitute ist bisher weitestgehend ungeklärt. Weitere Arbeit in diesem Bereich wird daher von großem Nutzen sowohl für die Kapitalmärkte als auch für die Finanzindustrie sein.

Laut meiner Dissertation sind die Konsequenzen für Manager, die ihre Aufsichtspflicht vernachlässigen und verletzen, ein erhöhtes Klagerisiko von Seiten der Aktionäre. Der Fokus meiner Studie in Kapitel 2 befasst sich mit langfristigen Konsequenzen für den Aktienpreis, den Firmenwert, sowie dem Firmenverhalten im Anschluss an eine Aktionärsklage. Ziel ist es, herauszufinden, ob individuelle Manager durch Sammelklagen der Aktionäre disziplinarisch bestraft werden können, was sich über einen längeren Zeitraum in einer besseren Performance widerspiegeln kann. Ob dies der Fall ist, hängt davon ab, ob Manager das Klagerisiko als eine glaubwürdige Bedrohung empfinden, und ob eine Verhaltensänderung im Zuge dessen erfolgt. Aufgrund der Tatsache, dass sowohl persönliche als auch finanzielle Konsequenzen für Manager recht gravierend sein können, kann das Risiko als glaubhaft eingestuft werden. Für Unternehmen, denen Bilanzfälschung oder die Durchführung illegaler Geschäftspraktiken zu Last gelegt werden, stellen Sammelklagen in dieser Form, ein nachhaltig negatives Ereignis für den Aktienpreis und dessen Performance dar. Eine mögliche Outperformance geschieht jedoch nicht auf Kosten eines erhöhten Zinsausfallrisikos: in Form einer Annäherung des KMVMerton Modells der erwarteten Zinsausfall-Wahrscheinlichkeit finde ich, dass diese nach der Sammelklage eher sinkt als steigt. Die langfristigen Auswirkungen auf den Aktienpreis unterscheiden sich auch nicht zu den Firmen, die bereits vor Einleitung der Sammelklage, mit entscheidenden auslösenden Ereignissen konfrontiert wurden. 
Daraus ist $\mathrm{zu}$ schließen, dass die Sammelklage an sich für die langfristige Aktienperformance verantwortlich ist. Die Verwendung des vereinfachten KMVMerton Modells birgt laut meiner Studie mehrere Vorteile. Zum einen haben Credit Ratings den Nachteil, dass diese nur für Firmen mit gehandelten Anleihen verfügbar sind, was die Stichprobengröße um ein Drittel schrumpfen ließe. Zum anderen werden Rating Agenturen oft wegen Interessenkonflikten kritisiert, was sich durch das „,issuer pays“ (die Firma bezahlt die Rating Agentur, um eine Einstufung des Kreditrisikos zu erhalten) System ergibt. Somit hat eine Rating Agentur nur begrenzte Anreize, die Kreditwürdigkeit eines Unternehmens herabzustufen.

Kapitel 3 interpretiert das Aufkommen von Sammelklagen eher in einem Corporate Governance Kontext im Vergleich zu anderen Studien, die diese mehr als Antwort auf (oder Auslöser für) schlechte Performance beziehen. Laut meiner Studie erfolgen diese Sammelklagen als Antwort auf dysfunktionales Verhalten von CEOs, welches durch falsche Anreize in der Vergütungsstruktur ausgelöst wird. Im Bezug auf Kontrolle und Managervergütung befinden sich Aktionäre in mehreren Zielkonflikten: Aktionären fehlt es zum einen an Koordinationsvermögen, die Corporate Governance Struktur der Firmen zu verändern, und zum anderen an nötigem Wissen und Abschätzungsvermögen für die Ansetzung der richtigen Anreizstruktur für Manager. Darüber hinaus bietet die Vergütung in Form von Aktienoptionen durchdringende Vorteile für alle Seiten. Als Konsequenz dessen verfügen Manager über ausreichende Diskretion, ihren Informationsvorsprung zu nutzen und die Vergütungsstruktur selber festzulegen. Im Zuge dessen wird der Manager einen Anreiz haben, das Firmenrisiko (zum Beispiel in Form von Cash Flow Volatilität) zu erhöhen und sich strategisch im Bezug auf Veröffentlichung von Informationen an die Finanzmärkte zu verhalten. Allerdings haben Manager in dieser Hinsicht nicht die freie Handlungsvollmacht, sich in eigenem Interesse zu verhalten. Die Lösung in dieser Situation ist die Option der Aktionäre, gegen Firmen und Manager vor Gericht zu ziehen. Die Bedrohung dessen ist wegen finanzieller und persönlicher Konsequenzen ausreichend, um abzuschrecken bzw. korrigierend einzugreifen. Allerdings sind Gerichtsverfahren und Sammelklagen für den Investor aufwändig: sowohl in direkter Form durch Anwalts- bzw. Gerichtskosten als auch in indirekter (meist auch höherer) Form durch den Zeitaufwand für Beobachtung, Bewertung, und Einschätzung der Informations- und Firmenlage. Als Alternative hierzu wurde in den USA 2002 der Sarbanes-Oxley Act (SOX) verabschiedet, der Manager zu einem erhöhten Grad haftbar machen kann. Bisher wurde die Einführung des SOX auf Makro-Ebene kritisiert, da seine Befolgung sich insbesondere für ausländische Unternehmen als $\mathrm{zu}$ kostspielig darstelle. Des Weiteren benachteilige SOX die USA als internationalen Aktienmarkt gegenüber internationalen Finanzzentren wie London, Paris, oder Frankfurt. Auf Firmenebene jedoch ermöglicht SOX einen wichtigen Kontrollmechanismus für Aktionäre und drosselt exzessive Risiken der Firmen durch höhere individuelle Haftbarkeit. 
Kapitel 4 hingegen nimmt eine neue Perspektive ein. Statt die Beziehung zwischen Aktionären und Managern im Bezug auf Interessenkonflikte zu beleuchten, ist der Fokus der Studie das Verhältnis zwischen Firmen und Finanzinstituten. Exemplarisch dargestellt wird dies in dem Kontext von Börsengängen (initial public offerings - IPOs), bei denen der Emittent eine Investmentbank mit der Platzierung der Aktien im Markt beauftragt. Investment Banken sind Finanzintermediäre, die den Handel auf Wertpapermärkten ermöglichen und vereinfachen. Zwischen 1998 und 2000 gab es in den USA eine Vielzahl von Fällen, in denen diese Börsengänge von Unternehmen mutmaßlich von der Investment Bank (dem „Underwriter") manipuliert wurden. Als Konsequenz dessen lag der Marktpreis am ersten Handelstag weit über dem Ausgabepreis (der Unterschied zwischen den beiden Preisen wird als ,underpricing“ bezeichnet). Dieses „underpricing“ überstieg seinerzeit Werte, die fernab jeglicher Theorie lagen und mit konventionellen Preismodellen nicht $\mathrm{zu}$ erklären waren. Auch Spekulationstheorien und Erklärungen durch Irrationalität der Marktteilnehmer greifen zu kurz. Eine Antwort zu diesem Underpricing-Phänomen liegt in der Möglichkeit der Investment Bank, die Aktien zum Ausgabepreis in Kombination mit einem Kopplungsverkauf (sogenannte „tie-in“ Geschäfte oder „laddering“ Verträgen) zu platzieren. Dabei bekommt ein Investor, der eine Aktie zum Emissionspreis zeichnet, diese nur zugeteilt, wenn er auch zustimmt, an einem bestimmten Datum in der Zukunft, weitere Aktien zum Marktpreis zu erwerben mit einem vorher festgelegten Faktor $x$. Die Investment Bank schafft es dadurch, sowohl den Ausgabe- als auch den Marktpreis der Aktien und die Platzierung selbst zu erhöhen. Die teilnehmenden Investoren erhoffen sich eine hohe Rendite der Aktie und somit ermöglicht deren künstliche Nachfrage eine Stabilisierung der Preise. Weitere Stabilisierung nimmt der Underwriter durch die Asset Management Teile des Finanzkonglomerates vor, zu dem er gehört. Leider ist es nicht möglich die Rückführung der Profite der Investoren an den Underwriter genau zu überprüfen. Allerdings gibt es Hinweise (Cliff and Denis, 2004) und Einzelberichte (red herring, 2001), dass diese sogenannten ,soft-dollars“ existieren. Somit zeigt diese Studie, wie eine Investment Bank als Marktteilnehmer Informationsungleichheit für den eigenen Vorteil ausnutzen kann. Gesetzgeber und Behörden sind weitestgehend machtlos, diese Praktiken zu unterbinden, da die betroffenen Parteien als Reaktion wahrscheinlich eine unauffälligere unterschiedliche Form der Manipulation finden.

Kapitel 5 wechselt wieder auf die Aktionärsperspektive und fragt, inwieweit Investoren Kontrolle auf Firmen und Manager ausüben können. Wie reagieren Aktionärsgruppen, wenn ein Unternehmen schlechte Performance liefert? Der Aktionär wird aktiv. Generell unterscheidet man zwischen zwei Formen dieses Aktivismus: zum einen kann ein Investor mit großen Unternehmensanteilen bei Unzufriedenheit mit Strategie bzw. Managementleistung einfach die Aktien verkaufen und damit einen Preisdruck ausüben. Eine andere Form der Kontrolle ist, 
auf Aktionärsversammlungen Vorschläge zur Änderung des Managements und zur Anpassung der Konzernstrategie vorzubringen. Beide Formen sind nur bedingt universell praktikabel, da der Investor für einen Preisdruck durch Verkauf einen Mindestanteil halten muss, um glaubhaft zu wirken. Da der aktive Investor, der Vorschläge auf Aktionärs- und Jahreshauptversammlungen vorbringt, die alleinigen Kosten und den Aufwand seines Aktivismus trägt, entsteht eine Situation des ,freeriding“. Das bedeutet, dass andere Aktionäre die vollen Vorteile des Aktivismus des Einzelnen genießen und somit durch seinen alleinigen Aufwand profitieren. Daher entstehen Koordinationsprobleme zwischen Investorengruppen. Der Erfolg beide Formen des Aktivismus bleibt darüber hinaus auch nur Investoren bestimmter Größe vorbehalten. Das bedeutet allerdings nicht, dass Aktivismus auf Hauptversammlung keine Form effektiver Kontrolle darstellen kann. Die Grundannahme der Studie ist, dass jegliche Art von öffentlichem Aktivismus an die Firma und an die Finanzmärkte ein negatives Signal sendet. Somit ergeben sich Kosten für den Manager, die vermieden werden sollten. Kapitel 5 erforscht dies anhand einer Situation, in der Firmen in einer weitestgehend konzentrierten Industrie mit wenigen Wettbewerbern operieren. Darüber hinaus ist das Unternehmen vor feindlichen Übernahmen geschützt durch sogenannte „Verteidigungsstrategien“, welche jegliche Form von Managementdisziplin unterbinden. Sowohl Produktmärkte als auch der Markt für Manager und Firmenübernahmen sind sogenannte „Marktmechanismen“, die sicherstellen sollen, dass der Manager im Interesse der Aktionäre handelt.

Der Manager ist im Fall von Kapitel 5 durch zweierlei Arten der Positionsgefährdung geschützt, indem seine Firma a) weniger durch ein schwaches Produkt aus dem Markt getrieben werden kann und b) schwieriger durch eine andere Firma aufgekauft werden kann, weil der Marktwert durch schlechtes Wirtschaften zu niedrig getrieben wurde. Potentiell könnten Manager sich somit ihren Pflichten entziehen, da sie den Marktmechanismen nur begrenzt ausgesetzt sind. In dieser Situation ist die optimale Reaktion der Aktionäre, Anreize für den Manager in Form von Vergütungsvorschlägen zu schaffen. Dies birgt jedoch den Nachteil, dass Manager zu Eigentümer der Firma gemacht werden, und ebenfalls ein Stimmrecht erhalten. Dieses verwenden sie aktiv, um gegen Vorschläge der Aktionäre in anderen Bereichen zu stimmen. Allerdings schaffen es die Aktionäre mit den vorgebrachten Vorschlägen, ein öffentliches Signal schlechter Performance der Manager zu liefern, was eine disziplinarische Funktion haben kann. Dies ist unabhängig von der Erfolgsquote der Vorschläge. Die Einzigartigkeit meiner Datenbank ermöglicht es daher, Aktivismus von Aktionären in ein neues Licht zu rücken. Als Reaktion bringen Manager nun selbst Vorschläge hervor auf Versammlungen, die aufgrund von Koordinationsschwierigkeiten unter Kleinanlegern und institutionellen Investoren eine bedingungslose Akzeptanzrate von über 95\% haben (Gillan und Starks, 2007). Zwar können Manager durch den Aktivismus der Aktionäre kein vermeintlich ,ruhiges Leben“ genießen, allerdings 
haben die Aktionäre auch keine effektive Kontrolle mehr über die Firma. Daraus ergäbe sich der Abschlag zum Marktwert des Unternehmens, der bereits durch Giroud und Müller (2009) erforscht und festgestellt wurde.

Die vorhergegangenen Studien befassen sich ausschließlich mit dem U.S. Aktienmarkt. Auch wenn der amerikanische Aktienmarkt der größte Aktienmarkt weltweit ist, der am meisten liquide ist, lässt sich Corporate Governance als Kontrollmechanismus für Aktionäre nicht für internationale Märkte verallgemeinern. In amerikanischen Unternehmen muss der CEO primär Wert für Aktionäre schaffen. Dies ist allerdings keine global gültige Betrachtungsweise: das deutsche bzw. japanische System nimmt einen ganzheitlicheren Ansatz für Unternehmensführung unter Berücksichtigung von Mitarbeitern, Kunden, bis hin zu Versorgern. Welche der zwei Möglichkeiten Firmen wählen, hängt im Endeffekt vom Grad der Internationalisierung der Wertschöpfungskette, vom Listing-Status der Aktien, sowie von der Investorenbasis ab.

Im letzten Kapitel der Dissertation untersuche ich, ob die zunehmende Internationalisierung der Investorenbasis dazu führt, dass Unternehmen anstreben, kurzfristige Werte für die Aktionäre zu erzielen. Dieses Ergebnis ist laut dem amerikanisch-/britischen Corporate Governance System bevorzugt. Einzelne Berichte über den niederländischen Konsumriesen Royal Ahold sowie die reaktionäre Trennung des Daimler Konzerns von Chrysler an den U.S. Finanzinvestor Cerberus in 2007 geben Anlass zu meiner Hypothese, dass sich Firmen aus Kontinental-Europa zunehmend dem amerikanisch-/britischen Corporate Governance System annähern werden. Mithilfe einer Datenbank, die die Corporate Governance Qualität der 300 größten gelisteten europäischen Unternehmen misst, finde ich in Kapitel 6 heraus, dass dies tatsächlich der Fall ist. Die Ergebnisse sind hierbei für einen Bereich stark ausgeprägt, der europaweit am wenigsten reguliert ist: nämlich der Art und Weise wie Unternehmen gegen feindliche Übernahmen geschützt werden. Als Schlussfolge hieraus ziehe ich, dass es einen Markt für europäische Corporate Governance für Firmen aus Kontinental-Europa gibt.

Insgesamt zeigt die vorliegende Dissertation, inwiefern sich in den Finanzmärkten Informationsvorteile für bestimmte Parteien ergeben und wie mit diesen umgegangen wird. Das Management der Investorenbasis, das mögliche Ausnutzen von Informationsvorteilen sowie das Steuern des Aktienpreises geben meiner Arbeit den Titel: „Stock Market Manipulation“. Inwieweit diese Informationsvorteile $\mathrm{zu}$ forensischen Zwecken genutzt werden, ist Aufgabe für zukünftige Forschungsarbeit auf diesem Gebiet. 


\section{Curriculum Vitae}

Robin Braun was born on 29 January 1981 in Leverkusen, Germany. He attended high school between 1994 and 2000 at the Lise-Meitner-Schule Städtisches Gymnasium in Leverkusen. Subsequently, he studied International Business Studies at Maastricht University. During that time he also worked for Bayer AG in Leverkusen. In the course of this study, he spent a semester abroad at Università Cattolica del Sacro Cuore in Milan (Italy). In April 2006 he received his Master's degree in International Business with a Major in Finance. His final thesis was supervised by Professor Rob Bauer and was titled "Corporate Governance in Europe".

In April 2006 Robin joined the Department of Finance at Maastricht University as a PhD candidate. He has also been affiliated with the European Centre for Corporate Engagement (ECCE) and acknowledges any financial support for his research activities. The results of his work with international co-authors on stock market manipulation are presented in his dissertation. His research benefited from financial support from The Foundation for Strategic Environmental Research (MISTRA). He performed parts of his research while attending New York University (NYU), Stern School of Business as a visiting scholar. He was also teaching assistant for several courses covering the whole spectrum of corporate finance from corporate governance and executive compensation over change in control transactions to venture capital and private equity.

His work has been presented at various universities and international conferences, including New York University, Oxford University, Luxembourg School of Finance, Aarhus School of Business, Université Catholique de Louvainla-Neuve, Financial Management Association, and European Financial Management Association and in the context of various ECCE conferences in Umeå, Rome, and Maastricht. His work has been published or is forthcoming in international refereed academic journals. Since July Robin is working for DWS Investments $\mathrm{GmbH}$ in Frankfurt (Germany). Subsequently, Robin will start a post-doctoral research position with the Luxembourg School of Finance. 